UNIVERSIDADE DE SÃO PAULO

FACULDADE DE FILOSOFIA, LETRAS E CIÊNCIAS HUMANAS

DEPARTAMENTO DE HISTÓRIA

PROGRAMA DE PÓS-GRADUAÇÃO EM HISTÓRIA SOCIAL

NO INTERIOR... DITADURA MILITAR E ENSINO SUPERIOR (FAFI/UNESP)

Memórias Sobre a Intervenção na Faculdade de Filosofia, Ciências e Letras de São José do Rio Preto.

Maria Aparecida Blaz Vasques Amorim

São Paulo - 2009. 
UNIVERSIDADE DE SÃO PAULO

FACULDADE DE FILOSOFIA, LETRAS E CIÊNCIAS HUMANAS

DEPARTAMENTO DE HISTÓRIA

PROGRAMA DE PÓS-GRADUAÇÃO EM HISTÓRIA SOCIAL

NO INTERIOR... DITADURA MILITAR E ENSINO SUPERIOR (FAFI/UNESP)

Memórias Sobre a Intervenção na Faculdade de Filosofia, Ciências e Letras de São José do Rio Preto.

Maria Aparecida Blaz Vasques Amorim

Dissertação apresentada ao Programa de Pós-Graduação em História Social do Departamento de História da Faculdade de Filosofia, Letras e Ciências Humanas da Universidade de São Paulo, para a obtenção do título de Mestre em História Social.

Orientador: Professor José Carlos Sebe Bom Meihy

São Paulo, junho de 2009. 


\section{Folha de Aprovação}

Maria Aparecida Blaz Vasques Amorim

NO INTERIOR... DITADURA MILITAR E ENSINO SUPERIOR (FAFI/UNESP)

Memórias Sobre a Intervenção na Faculdade de Filosofia, Ciências e Letras de São José do Rio Preto.

São Paulo, junho de 2009.

Prof. Dr. José Carlos Sebe Bom Meihy

Nome:

Nome: 
Queria voltar ao que nos pertence com um poema na medida do impossível. (Mário Quintana) A meu pai, Antonio Blaz Durão, por tudo... saudade. 


\section{AGRADECIMENTOS}

Agradeço primeiramente aos meus pais que estiveram sempre presentes, mesmo quando ausentes.

Ao meu marido, Moacir, pelo companheirismo, força e apoio, sempre. Aos meus filhos Mayra, Melina e Philipe pelo auxílio contínuo e por confiarem em mim mais que eu mesma. Ao Rondinelli, pela insistência.

Ao Professor José Carlos Sebe Bom Meihy, meu orientador, pela acolhida, pelo acompanhamento constante, por tudo que me ensinou, com paciência, carinho e a humildade característica dos grandes mestres.

Aos amigos do NEHO, onde pude praticar o trabalho coletivo.

A Ricardo, Juniele e Suzana e Fernando...o mundo é melhor porque eles existem.

A FAPESP pela bolsa concedida, que auxiliou em muito o desenvolvimento deste trabalho.

Agradeço, profundamente meus colaboradores, que me receberam e partilharam comigo parte tão importante de suas vidas.

Aos leitores atentos que gentilmente aceitaram participar da minha banca de qualificação, Professora Sara Albieri e Professor Antonio Rago Filho. A outros mestres que colaboraram com dicas, sugestões e apoio:Professora Vera Lúcia Vieira, Professora Yvone Dias Avelino e Professor Ramon Américo Vasques.

A Newton Ramos de Oliveira pelo auxílio na busca pelos meus colaboradores. Ao Rodrigo, do Diário da Região, e à equipe do jornal, pelo apoio e acolhida.

Aos meus irmãos Marco Aurélio, Cecilia e meus sobrinhos Larissa, Bruna, Ana Júlia, Caroline e Vinicius pelo amor e momentos de alegria.

Aos funcionários do Departamento de História e do Programa de PósGraduação em História Social da USP minha eterna gratidão. 
Gigante de Espuma

Ainda ontem

Estive com o Brasil nas mãos.

Era um mapa recortado, Feito de espuma de náilon.

Um mapa branco,

Macio, flexível,

Sem divisas,

Sem rios,

Sem montes,

Sem vales, Sem gente, Sem nada, Uma mapa apenas.

Era o modelo de um Brasil sem fome,

Sem filosfia,

Sem religião,

Sem política,

Sem preconceitos,

Sem submissão, 
Sem homens.

Era um Brasil irreal.

Olhei-o bem:

De leste a oeste,

De norte a sul,

De espaço a espaço.

E acompanhei as curvas do contorno,

Na branca e leve espuma

Do "Gigante Adormecido",

Em seu lendário berço esplêndido.

“Gigante Adormecido"!...

Gigante desmaiado, pensei

Gigante desacordado há não sei quanto.

Berço enfermo, roubado diariamente.

Monstro afogado no mar,

Asfixiado no ar,

Onde cambaleia, ainda faminta,

A grande família cristã 
Com sua ideologia vaga.

Pátria amada da pobreza, Circo dos milionários, Mãe dos que vivem com fome, Mísera serva de alguns homens.

Ah! Que triste realidade Vi naquele mapa, Naquele Brasil! Os poros gasosos de espuma alva, Eram como se fossem túmulos, Ao invés de bolhas de sabão. Túmulos que não bastariam Para os anjinhos que morrem todo dia, Bolhas que dariam de sobra Para os que sobrevivem.

E eu que pensava Num Brasil de aço, Num Brasil compacto, Num Brasil de amor, 
Num Brasil cheio de amanhãs.

Tive vontade de estraçalhar Aquele molde elástico, Torsível, Instável, Que ainda ontem, Segurei nas mãos. Gigante de Espuma, de Edson Guiducci in Desova Poética publicada pelo GRUTA. 


\section{RESUMO}

A 435 km da cidade de São Paulo, longe dos grandes centros, em São José do Rio Preto, o Golpe Militar de 1964 também se manifestou. No dia $1^{\circ}$ de Abril de 1964, os interventores estavam a postos dentro da Faculdade Isolada de São José do Rio Preto, hoje UNESP. Isso porque desde o final dos anos 1950, uma intensa movimentação cultural acontecia. De lá partiam anseios reais e objetivos com relação à educação pública de qualidade, alfabetização de adultos, reforma universitária e conscientização do povo através da arte.

Os responsáveis por esses movimentos eram os integrantes do grupo de teatro amador GRUTA, criado pelo Professor Orestes Nigro, que surgiu como uma alternativa cultural aos estudantes.Estabelecendo intercâmbio com artistas consagrados, se apresentava nas cidades da região e em outras universidades Isoladas do interior paulista.

As atividades passaram a se articular com propostas políticas de esquerda, juntando-se, por exemplo, ao MPC (Movimento Popular de Cultura) que havia sido fundado pelo Professor Wilheim Heimer, alemão, docente da faculdade.

Com a intervenção, professores e alunos envolvidos nesses movimentos foram presos. O presente trabalho, valendo-se do recurso de História Oral, busca registrar, estabelecer e analisar narrativas dos sujeitos que atuaram como educadores e alunos deste grupo, desejando contribuir para a compreensão de suas experiências e dos resultados dessa intervenção para a educação superior brasileira.

Palavras Chaves: Ditadura Militar; FAFI; São José do Rio Preto; História Oral; Universidade 


\begin{abstract}
Far 435 kilometers from São Paulo, far away from big cities, in São José do Rio Preto, the Military Coup of 1964 in Brazil was demonstrated. On april , 1rst, 1964, the interventor were inside the University of São José do Rio Preto, today UNESP. This happens because since the 1950 years, an intense cultural movement was on course. There were a real and objective desire for a high quality public education, university reform and make people aware through the art.

Those whom were responsible for all of this were teachers and students from a non professional theater group created by Professor Orestes Nigro, called GRUTA, and its was supposed to be a cultural alternative for the students. Anyway a intense exchange started with a lot of established artist and its group start to present the plays in other cities and other universities.
\end{abstract}

The Theater group activities started to joint the proposal with left-wing groups, getting together, for example, to the MPC ( Popular Cultural Movement) that was created by Professor Wilheim Heimer, germany, a university teacher.

With the Military Coup teachers and students were put in jail. This assignment, using Oral History searchs to register, to establish and to analyze the subjects oral narratives of this group, teachers and students, wishing to contribute to understand their experiences and the results of this intervine for the superior education on Brazil.

Key-Words: Military Coup; FAFI; São José do Rio Preto; Oral History; University 


\section{SUMÁRIO}

Apresentação

\section{$\underline{\text { Parte I }}$}

História do Projeto

$\underline{\text { Parte II }}$

História, Memória, Identidade e História Oral.

$\underline{\text { Parte III }}$

O Cenário Histórico e a questão Político-Cultural. .36

Historiografia. .57

$\underline{\text { Parte IV }}$

Sobre o Ensino Superior no Século XX. .65

No Interior. .66

$\underline{\text { Parte V - Entrevistas }}$

Orestes Nigro

Juca de Oliveira . .87

Franz Wilheim Heimer. .93

Celso Abade Mourão. .98

Hélio Leite de Barros. .107

Anoar Aiex.

Sara Rottemberg. 
Nilce Aparecida Lodi.....

Grigor Vartanian.

Maria de Lourdes Cápua.

Edson Guiducci.

Luiz Dino Viszotto

Coronel Antonio Ribeiro de Godói .148

Análise das Entrevistas.

152

$\underline{\text { Parte VI }}$

Considerações Finais.

.202

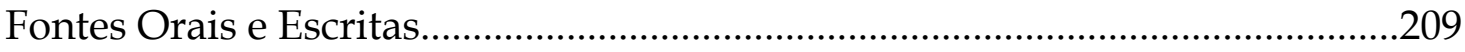

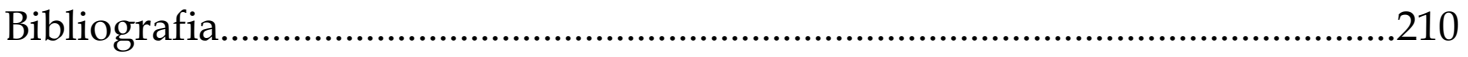

$\underline{\text { Anexos }}$

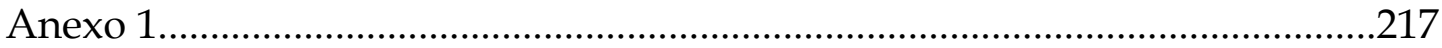

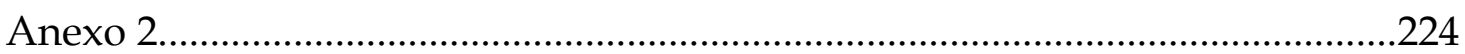

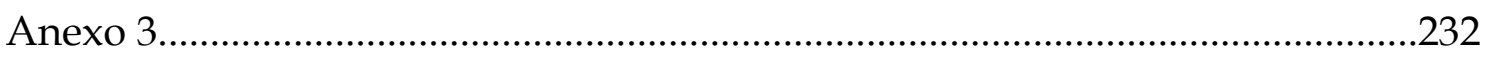

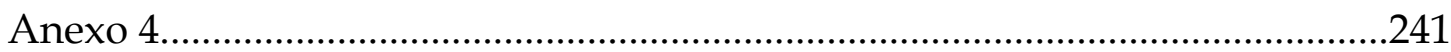




\section{APRESENTAÇÃO}

Houve um tempo, diz-nos Roberto Schwarz, em que o país estava irreconhecivelmente inteligente. "Política externa independente", "reformas estruturais", “libertação nacional”, "combate ao imperialismo e ao latifúndio": um novo vocabulário, inegavelmente avançado para uma sociedade marcada pelo autoritarismo, ganhava a cena, expressando um momento de intensa movimentação na vida brasileira. (SCHWARZ,R.1992)

O presente trabalho se insere neste período de tempo destacado por Schwarz que abarca as décadas 1950 e 1960.

O objetivo do estudo foi, em primeiro lugar, observar as experiências de vida dos indivíduos que trabalhavam, estudavam e participavam de movimentos culturais na Faculdade de Filosofia, Ciências e Letras de São José do Rio Preto, no interior do Estado de São Paulo, e em segundo, traçar a trajetória de tal instituição tentando entender os motivos que a levaram a ser a primeira faculdade no país a sofrer a intervenção após o Golpe Militar¹.

A História Oral Híbrida² foi o caminho que abracei, pois havia profusa documentação escrita e iconográfica que complementava tais histórias. Analisando tais fontes, entendi que se fazia necessário ouvir também àqueles, que, no interior de São Paulo e da Faculdade, se colocaram do lado dos que perpetraram o Golpe de 1964.

\footnotetext{
${ }^{1}$ Os trabalhos historiográficos sobre golpe civil-militar de 1964 são numerosos, destacando-se os estudos de Otávio lanni (1971), Maria da Conceição Tavares (1975), Francisco de Oliveira (1975), Moniz Bandeira (1978), René Dreyfus (1981), Florestan Fernandes (1981), Caio Navarro de Toledo (1981), Heloisa Starling (1986), Wanderley Guilherme dos Santos (1986), Angelina Figueiredo (1993), Daniel Aarão Reis (2002), Jorge Ferreira (2003), Carlos Fico (2004). O tema foi amplamente debatido no ano de 2004 em seminários sobre os 40 anos do golpe militar. Foi publicada, nesta ocasião, a obra 0 Golpe e a Ditadura Militar: 40 anos depois organizada por Daniel Aarão Reis Filho, Marcelo Ridenti e Rodrigo Patto Sá Motta.
}

2 A História Oral pode ser "pura" ou "híbrida". Dizendo de outra forma um projeto tanto pode ser, simplesmente, de constituição de um acervo - banco de histórias ou proposta em que as vozes dos narradores se cruzam entre si de maneira a promover uma discussão polifônica - ou, também, pode fazer as entrevistas dialogarem com outros tipos de fontes ou documentos.(HOLLANDA. MEIHY. 2008, p.128) 
Cada entrevista realizada, cada documento escrito analisado, fotografia ou artigo de jornal encontrado, trazia algo de novo e invariavelmente levava à trajetória

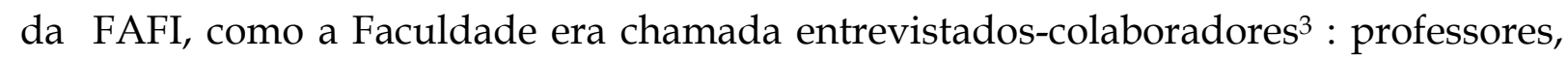
alunos e funcionários presos ou demitidos sumariamente, assim como àqueles que provocaram tais penalidades, por ocorrência do Golpe Militar de 1964, em São José do Rio Preto.

As entrevistas revelaram convergências e divergências vividas pelos indivíduos que compunham o quadro docente e discente da FAFI, assim como da sociedade riopretense e das autoridades que eram responsáveis pela lei, ordem e administração da cidade.

O Golpe de 1964 ocorreu no dia 31 de março, e em seguida, teve início uma verdadeira caçada a segmentos da sociedade que apoiavam o ex-presidente João Goulart, bem como a todos aqueles que possuíam ligações com o governo de Jango ou estavam ligados a movimentos populares e de educação. Assim que as Forças Armadas tomaram o poder, iniciaram a Operação Limpeza, que tinha como objetivo "limpar" os quartéis e a sociedade eliminando todos os elementos considerados subversivos e que se posicionassem contra o regime.

A perseguição não se restringiu aos militares, ampliando-se para outros setores da sociedade, em especial nos grandes centros do país, como Rio de Janeiro, São Paulo e, também, no Nordeste. A FAFI ${ }^{4}$ de São José do Rio Preto, as nove horas e trinta minutos, do dia $1^{\circ}$. de abril de 1964, sofreu intervenção.

A FAFI abrangia uma pluralidade de campos do conhecimento humano e desempenhou uma diversidade ampla de funções educacionais e culturais. A referida Faculdade nasceu num ambiente de choques de idéias, de lutas, dificuldades e incompreensões, mas não se furtou aos papéis para os quais foi criada: a difusão do saber, a elaboração da pesquisa e a produção intelectual.

\footnotetext{
${ }^{3}$ Colaborador é o termo utilizado por Meihy para a pessoa que narra sua história, e é importante na definição do relacionamento entre entrevistador e entrevistado. Sobretudo, é fundamental porque estabelece uma relação de compromisso entre as partes.

${ }^{4}$ Desde sua estadualização a FAFI passou a se chamar Instituto Isolado de Ensino Superior, porém essa nomenclatura foi, e é, pouco usada.
} 
Após a intervenção, a FAFI lentamente foi sendo convertida em diverso tipo de instituição e a transformação final aconteceu em 1976 quando recebeu a denominação de IBILCE/UNESP, Universidade Estadual Paulista “Julio de Mesquita Filho" , tornando-se um campus das faculdades que integram a Universidade. Quando da unificação, 14 dos chamados Institutos Isolados de Ensino Superior do Estado de São Paulo faziam parte da UNESP. Segundo Anna Maria Martinez Correa(2006), a criação desses institutos isolados ocorreu de maneira desordenada, sem que houvesse um planejamento efetivo.

Hoje, os institutos e faculdades que fazem parte da UNESP estão presentes em 23 cidades do interior paulista, abrigando mais de 32 mil alunos de graduação e 9,6 mil de pós-graduação.(CORREA.2006)

Segundo informações divulgadas pela UNESP: “A UNESP foi criada em 1976, com a reunião dos antigos institutos isolados de ensino superior, instalados pelo poder público, a parir da década de 20, em cidades com elevado grau de desenvolvimento".

A historiografia sobre a Ditadura Militar no Brasil é quase nula quando se fala do interior do Estado de São Paulo. Há duas teses, uma do Professor Newton Ramos de Oliveira e outra da Professora Dóris Accyoli e Silva, dois livros: o Livro Negro da USP que faz uma breve referência aos acontecimentos em São José do Rio Preto ocasionados pelo Golpe Militar e outro organizado pela Professora Anna Maria Martinez Correa que trata da trajetória da UNESP e um boletim, "Sapere Audi", elaborado pela Professora Nilce Lodi, que apresenta, em tópicos, as datas mais importantes para a instituição.

Por considerar importante que as lacunas historiográficas sejam preenchidas e pelo fato de eu mesma ser do interior e ter vivido a realidade, ainda que indiretamente, da Ditadura Militar, vi-me diante do desafio de compreender as relações entre indivíduos que compunham a sociedade riopreetense, a FAFI e que se refletiram na trajetória da Faculdade e na intervenção sofrida pela instituição em Abril de 1964.

Esta dissertação foi organizada da seguinte maneira: "História do Projeto" que trata de minha trajetória de vida e pesquisa, das etapas do projeto, de como realizei 
as entrevistas com os colaboradores, como busquei fontes documentais escritas, iconográficas e como as apresento nesse texto. Assim, espero conduzir o leitor para o interior, ou seja, para a atmosfera da pesquisa. A segunda parte engloba uma discussão sobre "História, Memória e História Oral" e apresenta reflexões obre História Oral, Memória e Identidade que são as questões teóricas metodológicas pelas quais optei. Na terceira parte apresento a questão político-cultural e o cenário histórico do Brasil e do exterior nos períodos anterior e subsequente ao Golpe de 1964. Ainda nesse capítulo apresento a historiografia sobre a Ditadura Militar utilizada nesse trabalho. Na quarta parte ofereço uma breve história do ensino superior no Brasil e apresento a história de São José do Rio Preto e da FAFI. No quinto capítulo apresento as entrevistas dos colaboradores e procedo à análise e o cotejamento das mesmas com as outras fontes que compõem o meu Corpus Documental . Na última parte estão as considerações finais.

Dos anexos constam fotografias, artigos de jornais e elementos do processo militar e que julguei importantes estarem presentes neste trabalho para que haja uma aproximação maior entre o leitor e a história narrada. 


\title{
PARTE I
}

\author{
Enquanto as histórias \\ Começam enquanto \\ O instante seguinte \\ Se abate sobre nosso \\ próprio \\ Coração.
}

(Desova Poética/ José Aluísio Reis de Andrade) 


\section{HISTÓRIA DO PROJETO}

Retraçando a trajetória seguida por esse trabalho, de sua concepção ao momento de seu arremate posso dizer que ela está profundamente ligada ao prazer de investigar e de ouvir histórias, fato comum aos oriundos do interior de São Paulo, como eu, onde crescem ouvindo "causos."

Devo dizer que pesquisar sobre episódios ocorridos no interior de São Paulo significa, muito mais que um trabalho de pesquisa, um reencontro com minhas origens, com pessoas que fizeram parte da minha vida num período tão importante como a adolescência. Durante a jornada para o desenvolvimento desse trabalho houve muitos reencontros e uma doce nostalgia insiste em me fazer companhia até o momento atual.

Nesse caminho houve obstáculos, escolhas a serem feitas, lágrimas quando a emoção do colaborador me contagiava e algumas incertezas. Pude contar, sempre, com o Professor José Carlos Sebe Bom Meihy que me acompanhou sem hesitação no processo de crescimento intelectual e pessoal que me transformaram numa pessoa, senão mais sábia, mais compassiva.

Nasci e fui criada numa cidade pequena, próxima a São José do Rio Preto, chamada Monte Aprazível. Estava no grupo escolar quando conheci um menino loirinho e inteligente cujo nome era Ricardo Nigro. Crescemos juntos, sua mãe foi nossa professora de Francês no Ginásio e no Colegial. Em torno do seu pai, cujo nome era Orestes Nigro, havia uma aura de mistério. Homem culto, fluente em Francês, sobrevivia dando aulas na Aliança Francesa, que ficava em um porão num dos casarões antigos da cidade.

Costumava ouvir que o Prof. Orestes era comunista e por isso as pessoas mais velhas do local costumavam criticá-lo, porém os jovens gostavam muito de sua companhia. Eu não sabia o que era ser comunista e em minha família essa palavra era proibida. 
Meus avós paternos e maternos eram espanhóis, de partidos políticos identificados com a direita, ${ }^{5}$ portanto, em casa jamais conseguiria explicações para ela. A primeira definição que assoalhei para essa palavra veio de um professor de História, por volta de 1969, quando certa manhã ao chegar à escola, me deparei com vários cartazes, cobertos de fotografias em preto e branco e no primeiro plano, escrito com letras garrafais estava: terroristas procurados, logo abaixo: ajude a proteger sua vida e a de seus familiares, e no final : avise a polícia.

Durante a aula de História o professor fez questão de dizer que aquelas pessoas eram perigosas, que não acreditavam em Deus e que pregavam o fim da família e da ordem. Tais cartazes ficaram gravados em minha memória porque as pessoas neles retratadas eram muito parecidas com pessoas "comuns". Não conseguia enxergar onde estava o perigo, e isso semeou dúvidas não dissipadas sobre o comunismo, que só foram satisfeitas muito tempo depois.

Há alguns anos li um estudo sobre o Professor Mauricio Traugtenberg que falava sobre a intervenção da FAFI em 1964 e da prisão de alguns alunos e professores daquela instituição, entre eles o Professor Orestes Nigro.

Quando ingressei no programa de Lato Sensu da Pontifícia Universidade Católica de São Paulo surgiu a idéia de estudar especificamente a intervenção na FAFI. Para desenvolver o trabalho procurei a UNESP de São José do Rio Preto onde contei com a atenção do Prof. Ceron, hoje diretor da Universidade, de sua secretária Mara e do ex-diretor Prof. Jhonny Rizzieri que permitiram que eu consultasse e fizesse cópias do Processo Militar, composto por 3.600 páginas, instaurado contra professores e alunos da FAFI por ocasião da intervenção ocorrida em 1964.

Decidi, então procurar as pessoas relacionadas naquele processo militar na condição de acusadas e ouvir delas a história da intervenção. Posteriormente, resolvi ouvir também aqueles que as haviam acusado.

\footnotetext{
${ }^{5}$ Ser de esquerda pressupunha uma opção ideológica que, em termos político-práticos, equivalia a estar do lado do socialismo contra o capitalismo, ou, em termos teórico-políticos, priorizar a igualdade em relação à liberdade. Ser de direita era o contrário. (Bobbio, 1994).
} 
Localizei inicialmente o Prof. Orestes Nigro que foi minha entrevista "ponto zero" $^{\prime \prime}$. A partir dele me aproximei de outros possíveis colaboradores.

Quando optei pela História Oral o Professor Sebe me fez três perguntas, segundo ele, fundamentais para quem faz a opção por um projeto de História Oral: História Oral de quem? Como? E por quê?

A primeira vem sendo respondida desde a apresentação desse trabalho. Pesquisa-se um grupo de pessoas que faziam parte da FAFI, em várias instâncias e da trajetória da instituição durante os anos de 1955 a 1964. As entrevistas de História Oral foram dimanadas do seguinte modo:

a) Localização dos professores que haviam sido presos ou sumariamente demitidos da Faculdade por ocasião do Golpe Militar.

b) Localização das pessoas que faziam parte do corpo da Faculdade e que eram a favor do Golpe.

c) As pessoas que fazem parte das alternativas a e b compõem o que chamamos em História Oral, de Colônia. Neste caso pessoas envolvidas com os acontecimentos decorrentes do Golpe.

d) Assim, formaram-se as redes. Redes são subdivisões de Colônia que indicam os critérios adotados para a escolha das pessoas a serem entrevistadas, neste caso, o envolvimento de cada uma com a FAFI nos anos de 1955 a 1964.

Nesta pesquisa trabalhei com cinco redes, uma constituída por professores que foram presos, outra por professores que foram demitidos, outra por alunos que foram presos, ainda uma com professores e alunos que estavam de acordo com o Golpe e a última por pessoas que não eram parte estabelecida da FAFI, mas que por alguma razão participaram de sua formação.

${ }^{6}$ Chama-se assim o primeiro entrevistado de um projeto que deve ser o sujeito que conhece a história do grupo com o qual se pretende trabalhar ou com quem se deseja fazer a entrevista central.(MEIHY.1996) 
Algumas peculiaridades no trabalho: Alguns professores já são falecidos* e devo à Professora Nilce Aparecida Lodi a entrevista que realizou com um deles em 1976 e gentilmente cedeu-me, a qual decidi utilizar pela sua importância. Outros, como os Professores Anoar Aiex e Franz Wilheim Heimer, estão fora do país e somente consegui entrevistá-los via internet", e outros ainda não querem lembrar. Respeitei suas vontades.

Entrevistei ainda o ator e escritor Juca de Oliveira, que ajudou na criação do Grupo de Teatro Amador, o GRUTA e participou ativamente dos movimentos culturais da Faculdade, mesmo não sendo membro do quadro discente ou docente da mesma. Todas as entrevistas foram transcriadas, segundo a linha de História Oral praticada pelo $\mathrm{Neho}^{8}$. Abaixo apresento uma tabela com os entrevistados, os lugares onde moram e quem foi o entrevistador:

\begin{tabular}{|l|l|l|}
\hline Nome & Origem & Entrevistador \\
\hline Orestes Nigro & São Paulo & Maria Aparecida \\
\hline Sara Rottemberg & São Paulo & Maria Aparecida \\
\hline Franz Wilhelm Heimer & Portugal & Maria Aparecida \\
\hline Maria de Lourdes Cápua & São Paulo & Maria Aparecida \\
\hline Hélio Leite de Barros & São Paulo & Maria Aparecida \\
\hline Anoar Aiex & Estados Unidos & Maria Aparecida \\
\hline Luiz Dino Vizotto & São José do Rio Preto & Maria Aparecida \\
\hline Edson Guiducci & Monte Aprazível & Maria Aparecia \\
\hline Grigor Vartanian & São José do Rio Preto & Maria Aparecida \\
\hline Nilce Aparecida Lodi & São José do Rio Preto & Maria Aparecida \\
\hline Juca de Oliveira & São Paulo & Maria Aparecida \\
\hline Celso Abade Mourão* & São José do Rio Preto & Nilce Lodi \\
\hline Coronel José Ribeiro Godói & São José do Rio Preto & Maria Aparecida \\
\hline
\end{tabular}

\footnotetext{
7 Há na internet uma ferramenta chamada skype, que permite uma conversa a viva voz.

8 Núcleo de Estudos em História Oral da USP
} 
À medida que ia encontrando os colaboradores recebia inúmeras fotos, jornais, livros de poesia, letras de paródias, que juntamente com o processo militar e as entrevistas compõem o meu Corpus Documental.

Analisando a documentação obtida optei por fazer uma distinção priorizando as narrativas. Ao estabelecer essa primazia firmo minha posição por uma história subjetiva na construção da memória de alguns sujeitos que fizeram parte do processo de intervenção na FAFI, seja como vencedores ou vencidos, isto porque considero que a memória construída é coletiva e, portanto, todas as narrativas são importantes para o trabalho.

A opção de priorizar as narrativas conduz a uma interpretação que parte das entrevistas e dialoga com outras preocupações, num movimento "de dentro" para "fora".

Este trabalho também se emoldura no que chamamos de História Oral Temática ${ }^{9}$, porém combina elementos de História Oral de Vida ${ }^{10}$. Não empreguei questionários, foram conversas abertas.

Segundo Meihy:

"Há projetos temáticos que combinam algo de história oral de vida. Nesses casos, o que se busca é o enquadramento de dados objetivos do entrevistado com as informações colhidas. Essa forma de história oral tem sido muito apreciada porque a informação ao ser mesclada à situações vivenciais, ganha mais vivacidade e sugere características do narrador" (2002. p.148)

Considero que a opção pela História Oral marca, também, minha presença nesse texto. Não fosse pelo fato de conhecer desde a infância a maior parte dos colaboradores, fui eu quem ouviu suas histórias, dando liberdade para que eles se expressassem com queriam, refletissem, comentassem e ficassem em silêncio quando as lembranças doíam muito. Imagino que essa liberdade tenha sido, por vezes, cerceada por minha presença, uma

\footnotetext{
9 História Oral temática é o recurso que busca analisar um determinado evento ou situação a ser esclarecida segundo o estabelecimento de questionários orientados para fins específicos.(MEIHY,1996)

${ }^{10}$ História Oral de vida tem como meta retraçar os caminhos de vivências pessoais que, contudo se explicam em grupos afins (sejam familiares, comunidades, coletivos que tenham destinos comuns).(MEIHY,1996)
} 
estranha que não conheceu a FAFI. É desses homens e mulheres, colaboradores com histórias entrelaçadas, a voz da narrativa: suas experiências, a vida, sonhos, decepções, traumas e impressões sobre passado e presente.

São meus a disponibilidade em ouví-los, o emprego de técnicas específicas para gravar as entrevistas, como a utilização do gravador. Ouvi, perguntei, mantive o silêncio de maneira a respeitar algumas posições declaradas por eles com as quais não concordava, me emocionei. Transcriei cada entrevista de maneira a deixá-la clara, compreensível, porém tentando conservar presente, em cada uma delas, a emoção sentida.

As análises estão articuladas às narrativas dos colaboradores e às fontes escritas que respondem aos meus questionamentos. Há o diálogo que faz com que eu esteja presente em todo o processo deste trabalho.

Este estudo contou sempre com as discussões periódicas do Neho, onde comecei a aprender sobre memória, identidade e narrativa e a perceber que, contrariando Walter Benjamim, o narrador não morrera ${ }^{11}$.

\footnotetext{
${ }^{11}$ Ver em: BENJAMIN, W. "O Narrador- Considerações sobre a obra de Nikolai Leskov". In: Obras Escolhidas: Magia, Técnica, Arte e Política. São Paulo: Brasiliense, 1985.
} 
PARTE II

Só lemos o que escrevemos

No imo do nosso ser.

Estava escrito, estava escrito,

Mas fui eu que descobri.

(Desova Poética/ Mara Jorge Ramos) 


\section{HISTÓRIA, MEMÓRIA, IDENTIDADE E HISTÓRIA ORAL}

O termo memória tem sua origem etimológica no latim e significa a faculdade de reter e /ou readquirir idéias, imagens, expressões e conhecimentos adquiridos anteriormente reportando-se às lembranças, reminiscências.(BEAR.1996).

O conceito de memória e a maneira como ela funciona vem sendo tema dos estudos de filósofos e de cientistas há séculos. Este conceito vem se modificando e se adequando às funções, às utilizações sociais e à sua importância nas diferentes sociedades humanas.(KESSE. 2005)

Como afirma Jacques Le Goff, "O conceito de memória é crucial." (LE GOFF. 1984) Tal afirmação pode ser recebida de duas formas: ressalta a importância da memória nas discussões contemporâneas no campo das humanidades, principalmente entre os historiadores e remete à importância fundamental da memória no debate atual acerca do problema da identidade, na medida em que a memória é um dos elementos constituintes e fundadores da identidade.

Os sentidos de herança ${ }^{12}$, construção ${ }^{13}$ e de identidade ${ }^{14}$ apontados por Pollack (POLLACK, M .1992,p.204), indicam que a memória é permeada do sentido não só do que ocorreu no passado, mas do tempo presente e de seus conflitos.

Pensar na construção da memória é pensar em variadas formulações conceituais, seja como um jogo entre as lembranças e o esquecimento, apontado por Freud, como uma construção social, materializada nos quadros sociais (linguagem, tempo e espaço). Para Halbawchs memórias individuais, grupais e coletivas, são construídas na subjetividade e representadas em discursos sociais. Pode-se, também, buscar pelos lugares da memória conceituados por Pierre Nora.

Á princípio a memória pode parecer ser um fenômeno de cunho pessoal, pois, cada indivíduo possui lembranças sobre sua trajetória de vida, no entanto os 
trabalhos de Maurice Halbwachs demonstraram que, talvez, o aspecto mais importante da memória seja o seu caráter social, como um fenômeno que é construído de forma coletiva, sendo, portanto, submetida a flutuações, transformações e mudanças constantes. (HALBWACHS, 1998).

A contribuição da psicologia para o conceito de memória, tanto no que concerne a recordação quanto ao esquecimento, assim como na questão da manipulação consciente ou não da memória individual ou coletiva, têm sido fundamentais. Neste sentido os esquecimentos e os silêncios são muito reveladores dos mecanismos de manipulação da memória.(CRUZ.2006)

Quais são os elementos que constituem a memória tanto individual quanto coletiva? Para alguns estudiosos da História Oral como Michael Pollack esses elementos são em primeiro lugar os acontecimentos vividos pessoalmente e em segundo lugar aqueles acontecimentos vivenciados pelo grupo ao qual o indivíduo se sente pertencer (POLLACK. 1992). Neste processo de construção de identidade o processo de socialização histórica da memória participa de forma tão efetiva e marcante que podemos falar de uma memória herdada. Ele assinala que a memória é uma atualização do passado ou a presentificação do passado e é também o registro do presente que permanece como lembrança. A memória pode ser considerada uma evocação do passado. É a capacidade que o homem possui de reter e guardar o tempo que se foi, salvando-o da perda total.

Para Pierre Nora existem lugares particularmente ligados a tarefa de fazer recordar um determinado passado, pois a memória é seletiva, nem tudo é lembrado, nem tudo é gravado, nem tudo é registrado, ou seja para lembrar é necessário esquecer (NORA. 1997).

Portanto, a memória é a representação do passado. (ROUSSO. In FERREIRA \& AMADO.1996). É uma reconstrução emocional e intelectual que acarreta uma representação seletiva do passado, um passado que nunca é individual, mas de um indivíduo inserido num contexto social, seja ele familiar, escolar, nacional. 
Assim, pode-se afirmar que a memória é individual e coletiva constituindo, destarte, um fenômeno construído, sendo possível também, estabelecer uma ligação intrínseca entre memória e identidade. Tal relação surge na medida em que a memória é um elemento constituinte da identidade, pois é a memória que cria as condições para o desenvolvimento do sentimento de continuidade e de coerência de uma pessoa ou de um grupo no seu processo de construção de identidade. Segundo Zygmunt Bauman a questão da identidade é a questão do momento (BAUMAN.2004).

Pollack concebe a identidade remetendo a três elementos essenciais: corpo e território (unidades físicas da identidade); continuidade temporal e sentimento de coerência. Como esses elementos funcionam como fatores de equilíbrio para o indivíduo se localizar individual ou coletivamente no mundo, a memória será também um elemento constituinte desse sentimento de continuidade e coerência para a reconstrução do si (POLLACK. 1992).

Portanto, a identidade é memória em ato. Ambos, campos de disputa e posicionamentos de referências sociais. A memória opera por uma ligação com o passado, enriquecendo o presente, selecionando pela lembrança e pelo esquecimento o que rememorar, sendo pleiteada também por fornecer um lugar de pertencimento, uma memória comum.

O pertencimento a um território de identidade a que me refiro não é um lugar geográfico, mas cultural. Por isso optei, nesta pesquisa, por abordar identidade como uma categoria histórico-cultural, construída e vivida sob a forma de discursos sociais, uma produção inacabada, um lugar de altercação em constante movimento de transformação, sempre constituída dentro da representação e nunca fora dela (HALL, S .1990).

Ainda que a memória seja preocupação comum a muitas áreas das ciências humanas, assim como a identidade, na história oral podemos relacionar esses elementos de maneira que um conduza ao outro. Em conjunto, memória e identidade se enlaçam possibilitando a realização e estudos que partam do tempo presente, de 
personagens vivos que mais que testemunhar um fato ou relatar trajetórias, permitam ver o processo de seleção dos acontecimentos, de constituição de discursos e assim se abram a análises que extrapolam a constatação dos fatos.

\section{Por que História Oral?}

A moderna História Oral nasceu na Universidade de Columbia, em Nova York, em 1947 a partir da organização sistemática e diferenciada de um arquivo, realizada por Allan Nevins, que oficializou o termo, que passou a ser indicativo de uma nova postura face as entrevistas. (MEIHY,J.1996, p.19)

Joutard afirma que ao longo do tempo, a História Oral foi usada por muitos pesquisadores para a elaboração de seus projetos, e que a partir dos anos 50 é que se retomou essa vivência, com intuito e criar instrumental para outros historiadores. (FERREIRA \& AMADO. 1996, p.45)

No Brasil a História Oral foi introduzida nos anos 1970, com a criação na Fundação Getúlio Vargas, de um programa de História Oral. No entanto foi só a partir dos anos 90 que ela passou a ter maior dimensão no país, com seminários, discussões entre historiadores brasileiros e estrangeiros e a criação da Associação Brasileira de História Oral, que congrega pesquisadores especializados nessa temática.

“Entre nós a História Oral tardou muito a se desenvolver em função de dois fatores primordiais: a falta de tradições institucionais não acadêmicas que se empenhassem em desenvolver projetos registradores das histórias locais, e a ausência de vínculos universitários como os localismos e a cultura popular. Além disso, os compromissos internos com cada disciplina universitária,como a sociologia e a antropologia, ficaram marcados muito fortemente, impossibilitando o diálogo entre os campos que tratavam de depoimentos, testemunhos e entrevistas". (MEIHY,1996) 
Como tudo que é novo, a História Oral despertou variadas concepções:

“Em nosso entender, a História Oral, como todas as
metodologias, apenas estabelece e ordena procedimentos de
trabalho - tais como diversos tipos de entrevistas e as
implicações de cada um deles para a pesquisa, as várias
possibilidades de transcrição de depoimentos, suas vantagens e
desvantagens, as diferentes maneiras de o historiador
relacionar-se com seus entrevistados e as influências disso sobre
seu trabalho - funcionando como ponte entre teoria e prática."
(FERREIRA \& AMADO.2001, p.16)

Outros defendem que a História Oral seja uma técnica, geralmente são pessoas envolvidas na constituição e preservação de acervos orais. Estes pesquisadores utilizam as fontes orais de forma esporádica, como fontes de informação complementar, normalmente ligados à sociologia, o que teoricamente justificaria essa postura.

Fazem-se necessárias, para o entendimento de como a História Oral será trabalhada neste projeto, algumas explicações sobre o lugar onde tomei contato com ela. O Neho, Núcleo de Estudos em História Oral, é resultado de duas experiências combinadas: uma pedagógica e outra de trabalho em oralidade em suas múltiplas formas. Para os integrantes do Neho a História Oral, mais do que entrevistas, é um processo de construção epistemológica.

A História Oral praticada pelo Neho/USP se assenta em pressupostos que identificam o processo histórico em sua dinâmica e desta maneira invertem o principio operacional que, sempre, parte do presente/imediato para o passado/remoto. Esta subversão qualifica a experiência que por sua vez é captada por trabalhos com a memória e a identidade. Memória e identidade, pois, tornam-se 
os binômios essenciais para a definição do que o Neho-USP entende por História Oral ${ }^{15}$.

Assim, vale dizer que a História Oral é um conjunto de procedimentos que se iniciam com a elaboração de um projeto, desdobra-se em entrevistas e cuidados com o estabelecimento de textos/documentos que podem ser analisados, arquivados para uso público, mas que tenham um sentido social. ${ }^{16}$

A História Oral pode ser dividida em três ramos principais: História Oral de vida, História Oral temática e tradição oral. História Oral de vida tem como meta retraçar os caminhos de vivências pessoais que, contudo se explicam em grupos afins (sejam familiares, comunidades, coletivos que tenham destinos comuns); História Oral temática é um recurso que busca analisar um determinado evento ou situação a ser esclarecida segundo o estabelecimento de questionários orientados para fins específicos e, finalmente, tradição oral é a prática decorrente do levantamento e estudo de mitos fundadores, questões ética ou morais e rituais do cotidiano e grupos. ${ }^{17}$

No trabalho de campo é fundamental a utilização de instrumentos que nos permitam gravar as entrevistas, sejam eles gravadores convencionais, digitais, câmeras de vídeo, MP3, MP4 ou qualquer outro tipo de tecnologia que sejam capazes de gravar o que nosso colaborador está dizendo. É fundamental que o pesquisador tenha ética, respeito e dê a devida importância a cada colaborador. "Cada pessoa é um amálgama de grande número de histórias em potencial, de possibilidades imaginadas e não escolhidas, de perigos iminentes, contornados e por pouco evitados". (PORTELLI.1997)

Para a História Oral o trabalho de campo se institui como momento fundamental para toda pesquisa. Nesta fase, existe um significado na relação social e humana entre pesquisador e colaborador da pesquisa que está intimamente ligada á 
ética que o profissional confere ao seu procedimento. “Tudo o que escrever ou disser não apenas lançará luz sobre as pessoas ou personagens históricos, mas trará conseqüências imediatas para as existências dos colaboradores e seus círculos familiares, sociais e profissionais" (FERREIRA \&AMADO. 1997)

Um conceito-chave, na História Oral, é o de mediação, instituindo para o oralista o papel de sujeito norteador de todo o processo de pesquisa, mas numa atitude de total respeito às expectativas, desejos e limitações de ordem prática e afetiva do colaborador.

Para o Neho a História Oral só se concretiza quando chegamos ao texto final e para isso há uma série de etapas para que nosso corpo documental esteja pronto para ser analisado pelo oralista e a devolução feita aos colaboradores.

- A entrevista deve ser conduzida segundo os critérios da história oral a ser adotada, de vida ou temática, e enquanto no primeiro caso não deve haver questionário rígido e deva ser conduzida de maneira aberta, na segunda o questionário faz-se necessário, porém, não deve ser duro, inquisitivo , que não dê abertura para outras lembranças que o colaborador sentir vontade de trazer à tona.

- A transcrição deve ser literal, realizada, de preferência, logo após a entrevista, quando as palavras do colaborador ainda estão presentes em nós. Ela deve ser a mais completa e rigorosa possível, registrando, inclusive sons externos, como, por exemplo, o telefone tocando, o gato miando..., os nés, entãos...

- Na textualização suprimimos as perguntas do entrevistador, pontuamos, formamos orações e tiramos repetições. Se estas forem uma característica do colaborador deixamos algumas para que o leitor as percebam.

- A transcriação deve conter em si a atmosfera da entrevista, seu ritmo, a comunicação não-verbal como risos, choro, gestos faciais e temos que ter cuidado porque o texto não pode abandonar a característica de originalmente falado e tem que ser identificado como tal pelo leitor. 
Para conseguir chegar a tal resultado, valemo-nos de dois conceitos da lingüística, que não podem ser entendidos separadamente: o de transcriação, proposto por Haroldo de Campos, e o de teatro de linguagem, formulado por Roland Barthes, ambos adequados à prática de história oral por José Carlos Sebe Bom Meihy. A transcriação surge da necessidade de transformar a transcrição literal em um texto mais agradável e compreensível à leitura. É importante ressaltar que não se adiciona ou se suprime idéias ao nosso colaborador. Este processo é árduo, uma passagem do oral para o escrito que leva o oralista a estar sempre atento à questão da ética. $\mathrm{Na}$ transcriação, a interferência do autor não deve ser negada, porém explicitada.18 ( MEIHY, J (org) .1996)

- Conferência e Legitimação: $O$ texto transcriado é devolvido ao colaborador para que ele analise, se reconheça ou não na entrevista, faça correções, alterações, adicione fatos, vete frases, de acordo com o que ele julgar conveniente; se o colaborador insistir em tirar partes inteiras do texto, entra o que chamamos de negociação, isto é, negociar com o colaborador para que as informações permaneçam no texto.

Após a conferência e legitimação o texto está pronto para a utilização como documento histórico, partindo-se para a análise e validação do mesmo. Validar uma narrativa é um ato de respeito ao colaborador. O texto produzido pelos encontros entre entrevistadores e colaboradores, obrigatoriamente tem valor intrínseco .

Apóia-se a relevância da validação em virtude do significado da história oral. Não fosse pela busca de outros ângulos de problemas que são, de regra, marcados pela objetividade, busca da verdade e comprovação, a entrevista seria mais uma maneira de adquirir informações, captação de dados ou certificação de fatos "reais". A "realidade" dos fatos advindas de entrevistas ligam-se a impressões. E história oral é o império das visões filtradas pelos pareceres. ${ }^{19} \mathrm{~A}$

18 Em www.gattaz.pro.br (site oficial do historiador André Gattaz onde ele publica artigos atuais não impressos) 
subjetividade é fundamental para a História Oral. Portelli, diz que é a subjetividade do expositor que fornece às fontes orais o elemento precioso que nenhuma outra fonte possui em medida igual. A História Oral, mais do que sobre eventos fala sobre significados. 


\section{PARTE III}

Choro a minha alma!

Choro a minha Pátria!

Choro o nosso Mundo!

(Desova Poética/ Nildemir Ferreira de Carvalho) 


\section{O CENÁRIO HISTÓRICO E A QUESTÃO POLÍTICO-CULTURAL}

Nos anos 1960, o cruzamento de variáveis históricas criou uma conjuntura na qual a revolução parecia não só possível, como ao alcance das mãos, divergindo-se, apenas no caminho que deveria ser seguido para atingi-la. Como seria essa revolução? Quais seus agentes principais? Quais ações poderiam desencadeá-la? Desse debate, que impregnou os movimentos sociais e as organizações de esquerda ${ }^{20}$ do período, não ficaram ausentes artistas e intelectuais. Pelo contrário, o liame entre política e cultura parece nunca ter sido tão intenso.

A revolução brasileira não veio pelas mãos das organizações de esquerda. Não foi sequer uma revolução. Foi um Golpe de Estado perpetrado pelos Militares e apoiado por segmentos da sociedade civil e eclesiástica.

Não se pode falar sobre a Ditadura Militar no Brasil não levando-se em consideração o contexto internacional. A Guerra Fria ${ }^{21}$ dividia o mundo em dois blocos opostos. Em janeiro de 1959, Fidel Castro, Che Guevara, Camilo Cienfuegos e outros ideólogos entravam vitoriosos em Havana, colocando abaixo a ditadura de Fulgêncio Batista. Cuba fica a cerca de 160 milhas náuticas de distância da Flórida, assim, quando, em 1961, Fidel Castro anunciou que a Revolução Cubana seguiria na direção do Socialismo foi inaceitável para os estadunidenses. Tanto pela proximidade do inimigo "em seu quintal" quanto pelo exemplo que potencialmente trazia a outras

20 O termo esquerda nesse trabalho designa, numa formulação, as forças políticas críticas da ordem capitalista estabelecida, identificadas com as lutas dos trabalhadores pela transformação social. Trata-se de uma definição ampla, próxima da utilizada por Gorender, para quem "os diferentes graus, caminhos e formas dessa transformação social pluralizam a esquerda e fazem dela um espectro de cores e matizes"(GORENDER.1987,p.7) Ver mais em:RIDENTI,M. Em Busca Do Povo Brasileiro: Artistas Da Revolucao, Do CPC a Era Da TV, Editora Record.

21 Guerra Fria é a designação atribuída ao período histórico de disputas estratégicas e conflitos indiretos entre os Estados Unidos e a União Soviética, compreendendo o período entre o final da Segunda Guerra Mundial (1945) e a extinção da União Soviética (1991). 
Nações colocadas sob a órbita de influência estadunidense desde a "Doutrina Monroe".22

Cresciam e se fortaleciam os partidos e movimentos de esquerda na América Latina: os Montoneros no Uruguai, os Tupamaros no Peru, o Partido Comunista no Brasil, o MIR (Movimiento de Izquierda Revolucionária) chileno, entre outros. Todos seduzidos pelo exemplo de um grupo idealista capaz de mobilizar as massas fazer a Revolução. Surgia no Cone Sul a polarização entre a direita e a esquerda.

Para falar sobre o Golpe Militar brasileiro e sua projeção sobre São José do Rio Preto, é necessário voltar o olhar para os anos 1950 suas articulações políticas e culturais. Desde tal período o conceito de cultura é remodelado através dos intelectuais que formam o ISEB, Instituto Superior de Estudos Brasileiros. Renato Ortiz considera o "ISEB como matriz do pensamento que baliza a discussão da questão cultural no Brasil dos anos 1950 até hoje" (ORTIZ.1985).

O ISEB foi o principal arauto das teses desenvolvimentistas e exercia influência na política dos governos JK e Jango. Forneceu os alicerces teóricos para as mais diversas correntes, inclusive para membros dos governos, além de quadros para os vários escalões desses mesmos governos. Foi criado no Rio de Janeiro, em julho de 1955, por um decreto do presidente interino Café Filho e recebeu subvenções da Capes (Coordenação de Aperfeiçoamento de Pessoal de Nível Superior). (PECÁUT.1990) A proposta do grupo de intelectuais que fundou o ISEB era assumir uma liderança na política nacional (GARCIA.2004) por seus próprios meios. Eles se dispunham a arregimentar e organizar as forças progressistas e esclarecê-las ideologicamente. Se autodefiniam como uma vanguarda capaz e bem organizada. $\mathrm{O}$ ISEB foi fechado pelos militares após o Golpe de 1964.

$22 \mathrm{Em}$ meio aos tumultos que explodiam por toda a América Latina a partir de 1810 - ocasionados pelas insurreições nativistas que buscavam a independência das suas regiões do domínio do império espanhol e do português , surgiu um documento, aprovado pelo Congresso norte-americano em 1823, que fez história - a Doutrina Monroe. Ela tornou-se o pilar das relações dos Estados Unidos para com o mundo daquela época e para com os seus vizinhos. Mas, com o passar do tempo, a mesma serviu como pretexto para os mais variados intervencionismos norte-americanos no continente e áreas contíguas. 
Fazendo um "contraponto" com o ISEB surgiu o IPES, (Instituto de Pesquisa e Estudos Sociais), que entre suas inúmeras e extensas atividades, organizava palestras, cursos, seminários com o propósito de levar a sua ideologia "a recrutas e também para moldar a força social empresarial em um bloco burguês de poder" (DREIFUSS.1981). Através de seu trabalho de formação político-ideológico, o IPES visava se constituir numa espécie de anti-ISEB.

Pode-se dizer que, enquanto o ISEB se constituiu num aparelho ideológico de Estado, o IPES foi uma típica formação ideológica no terreno da sociedade civil. O IPES não deixou de ter fortes e próximos vínculos com setores oficiais, em particular com a ESG (Escola Superior de Guerra) . Se os militares participaram ativamente do IPES, inclusive em cargos de direção, não se pode ignorar que foram os civis que tiveram a iniciativa de criar e comandar a instituição durante toda sua existência.(DREYFUSS.1981)

O engajamento que nasce nos anos 1950 e toma forma nos anos 1960 expressava-se pela crítica à política e à forma como ocorria o desenvolvimento do país e por um intenso debate sobre os rumos que se poderia imprimir à esta dinâmica social, no sentido de alterá-la. Ligados à UNE (União Nacional dos Estudantes), surgiam os CPC (Centro Popular de Cultura), que pretendiam colocar em prática estratégias para a construção de uma cultura nacional, popular e democrática. $\mathrm{O}$ termo cultura é um termo de várias acepções, em diferentes níveis de profundidade e diferentes especificidades.

O termo cultura, segundo Marilena Chauí, vem do verbo latino "colere" que originalmente era usado para o cultivo ou cuidado com a planta. Com o tempo, o termo foi empregado para os cuidados com pessoas, com deuses, o culto. $\mathrm{O}$ conceito de cultura evoluiu com o tempo. Até o Século XVIII, segundo Peter Burke, o conceito de cultura estava mais ligado às artes, aos livros e à música, mas hoje, assim como os antropólogos, os historiadores usam o termo cultura muito mais amplamente, para referir-se a quase tudo que pode ser aprendido em uma sociedade, como comer, beber, andar, falar, silenciar e assim por diante. Esta interpretação não é uma unanimidade. 
Segundo Nestor Canclini, o relativismo cultural, que impede que se possa comparar culturas, pois cada uma tem suas particularidades, conseguiu equiparar as culturas, mas não explica suas diferenças. Outra questão que Canclini coloca é a de que esse conceito não hierarquiza os fazeres humanos ditos como cultura, nem atribui a eles um peso dentro de uma determinada formação social. A definição proposta por ele diz que:

A cultura é :

“a produção de fenômenos que contribuem, mediante a representação ou reelaboração simbólica das estruturas materiais, para a compreensão, reprodução ou transformação do sistema social, ou seja, a cultura diz respeito a todas as práticas e instituições dedicadas à administração, renovação e reestruturação do sentido."(CANCLINI.2003)

Os cepecistas, lendo os arranjos de sistemas teóricos e políticos de pensadores e estadistas como Hegel, Husserl, Mannheim, Marx, Engels, Lênin, entre outros, numa interpretação favorecida pelos intelectuais do ISEB, e posteriormente em contato com conceitos de pensadores como Lukács, Gramsci, Sánchez Vázques e Benjamin que foram absorvidos e adaptados por eles, analisaram os conceitos de alienação associados a ideologia e construíram o conceito particular "cultura popular" nos anos 1960.

As perspectivas de transformações nacionais atraiam jovens intelectuais e artistas, mormente do CPC, que tratavam de desenvolver uma atividade conscientizadora, neste momento a cultura diz respeito a uma forma muito particular de consciência: a consciência política junto às classes populares. Na verdade, falavase em estimular, desenvolver uma cultura popular.

Foi nesse momento que a cultura nacional popular desvinculou-se do conceito de folclore, que ficou restringido ao passado. A cultura nacional passou a ser o instrumento possibilitador da ruptura do estado de subdesenvolvimento que o Brasil vivia na época. A cultura se tornou um instrumento de libertação. O Centro Popular de Cultura tinha como principais nomes Arnaldo Jabor, Cacá Diegues, Ferreira Gullar, Vianinha, entre outros. O CPC chegou a criar uma gravadora, uma editora, e 
produziu alguns filmes importantes. O trabalho do CPC era um incentivo para que os intelectuais se encontrassem com a massa, porque o povo, sem ajuda, era incapaz de apreender a cultura e formar uma identidade nacional. Sobre o papel do intelectual neste processo, Ferreira Gullar disse:

"A expressão 'cultura popular' surge como uma denúncia dos conceitos culturais em voga que buscam esconder o seu caráter de classe. Quando se fala em cultura popular acentua-se a necessidade de pôr a cultura a serviço do povo, isto é, dos interesses efetivos do país. Em suma deixa-se clara a separação entre uma cultura desligado do povo, não-popular, e outra que se volta para ele e, com isso, coloca-se o problema da responsabilidade social do intelectual, o que o obriga a uma opção." ( GULLAR. 1965)

Para Gullar ainda, " a cultura popular é a tomada de consciência da realidade brasileira"(GULLA.1965). Assim, surgiam indivíduos revolucionários e conseqüentes trabalhando a arte junto às fábricas e aos campos. Nas Universidades as propostas de reformas eram amplamente discutidas, visando não apenas problemas internos dessas instituições, mas também sua função social e a contribuição à conscientização popular e, portanto, do país, redimensionando-se o acesso e as finalidades da educação.

A vocação cultural que se observava no Brasil nas décadas de 1950/1960 não era um fenômeno pontual e nem único deste país. Pelo contrário, inscrevia-se em um contexto mais amplo e advinha do desenvolvimento contraditório que caracterizou as relações culturais internacionais desde o início da Guerra Fria, a onda de desenvolvimento europeu que Hobsbawn caracterizou como a terceira grande onda de desenvolvimento do capitalismo e a emergência dos protestos no mundo latinoamericano que marcam os anos 1950 e se desdobram nos demais.

O Brasil passava então, por intermináveis problemas que pareciam iriam ser resolvidos por Juscelino Kubitschek com seus 50 anos em 5. Embora o crescimento do país nessa época seja inquestionável, outros problemas sobrevieram, e então, Jânio Quadros parecia ser a solução, porém, após a renúncia intempestiva do mesmo , que 
levou a negociações com os militares para que o vice-presidente João Goulart pudesse tomar posse, o Brasil se tornou parlamentarista com Tancredo Neves como Primeiro Ministro. Um plebiscito reconduziu o país ao regime presidencialista com Goulart como presidente legítimo. O Plano de Metas proposto por ele precisava dar certo. A cultura nesse período vai estar engendrada com o intenso processo de industrialização sofrido pelo Brasil nos anos 1950/1960 que foi responsável por uma migração intensa do campo para a cidade.

O mercado de trabalho cresceu, assim como o mercado consumidor e conseqüentemente as camadas médias urbanas, de onde surgiram os intelectuais e simpatizantes dos setores populistas e de esquerda. Os intelectuais fizeram uma nova leitura da realidade brasileira, principalmente com relação à cultura, na verdade uma cultura política, onde subdesenvolvimento e dominação cultural eram as categorias centrais.

Havia a necessidade da busca do que seria nacional e democrático. Nesse contexto de busca por um país com menos contradições, tem importância o PCdoB, Partido Comunista do Brasil. O partido adquiriu um papel crescente na estrutura do desenvolvimento nacionalista, pois contava com numerosos e influentes intelectuais ao seu redor. (PECÁUT.1990)

Sua influência foi plenamente sentida sobre o ISEB (Instituto Superior de Estudos Brasileiros), mais tarde no CPC (Centro Popular de Cultura), da UNE (União Nacional dos Estudantes) e no MCP (Movimento de Cultura Popular) e no MPC (Movimento Popular de Cultura) ${ }^{23}$.

O CPC da UNE foi formado em 1962 e fechado pelo Golpe Militar em 1964. Segundo Renato Ortiz, a experiência do CPC está filosoficamente ligada ao ISEB. Sua meta era utilizar elementos da cultura popular para "desalienar" o povo. A alienação é uma categoria fundamental que os cepecistas utilizam para analisar a realidade brasileira. A cultura popular é vista como verdadeira enquanto a cultura das classes dominantes é alienada. (HOLLANDA.2004)

\footnotetext{
${ }^{23}$ Este último criado em São José do Rio Preto pelo Prof. Franz W. Heimer e inspirado no MCP de Pernambuco.
} 
A "desalienação" deveria ser buscada pela conscientização popular, que se daria pela instalação de uma cultura nacional e popular, portanto não se pode separar a questão do CPC e a da cultura popular nacional. Duas fases bem diferentes estão presentes no momento da organização dos CPCs : quem leva cultura, quem recebe cultura. ${ }^{24}$ No Relatório do Centro Popular de Cultura, constava que o movimento de cultura popular se daria pela atuação de dois grupos diferentes: a atuação para os grupos sociais e a atuação com os grupos sociais. ${ }^{25}$

A reinterpretação das principais teses dos isebianos por estudantes, artistas e intelectuais do CPC aconteceu e inspirou-se esteticamente no Teatro de Arena ${ }^{26}$ e ideologicamente no PCB e no ISEB. Entre a fundação em 1961 e a extinção em 1964, três nomes integraram a direção do CPC: Carlos Estevam Martins, Carlos Diegues e Ferreira Gullar, e embora houvesse divergências entre eles a questão da cultura popular nacional sempre esteve presente.

O MCP (Movimento de Cultura Popular) foi criado no Recife em maio de 1960. O movimento que teve como objetivo básico difundir as manifestações da arte popular regional e desenvolver um trabalho de alfabetização de crianças e adultos. Seu ideário era, em resumo, "elevar o nível cultural dos instruídos para melhorar sua capacidade aquisitiva de idéias sociais e políticas" e "ampliar a politização das massas, despertando-as para a luta social".(BARCELLOS.1994)

Na prática, esse trabalho era feito através de apresentação de espetáculos em praça pública; organização de grupos artísticos; oficinas e cursos de arte; exposições; edições de livros e cartilhas, etc. $\mathrm{O}$ trabalho de alfabetização tinha à frente o jovem educador Paulo Freire, que foi um dos sócio-fundadores do movimento. Também

${ }^{24}$ Cultura popular: conceito e articulação. Movimento, Rio de Janeiro, n.4, p.11-2, jul. 1962, p.12, grifo meu.

${ }^{25}$ RELATÓRIO do Centro Popular de Cultura [1962]. In: BARCELLOS, J. CPC da UNE: uma história de paixão e consciência. Rio de Janeiro: Nova Fronteira, 1994. 472p. p.441-56, p.444.

26 Fundado nos anos 1950, torna-se o mais ativo disseminador da dramaturgia nacional que domina os palcos nos anos 1960, aglutinando expressivo contingente de artistas comprometidos com o teatro político e social. 
integraram o MCP, intelectuais e artistas como Francisco Brennand, Hermilo Borba Filho, Abelardo da Hora, José Cláudio, Aloísio Falcão e Luiz Mendonça.

O MCP teve por sede o Sítio da Trindade, na Estrada do Arraial. Era uma entidade privada sem fins lucrativos e se mantinha através de convênios que, na prática, foram firmados quase que exclusivamente com a prefeitura do Recife e o governo do Estado.Além de recursos financeiros, a prefeitura do Recife chegou a colocar à disposição do MCP 19 viaturas e 30 imóveis. O movimento contou com apoio da intelectualidade pernambucana e de facções políticas de esquerda tais como a União Nacional dos Estudantes (UNE), Partido Comunista Brasileiro (PCB) e do CPC (Centro Popular de Cultura).$^{27}$

Devido ao clima político da época, o MCP ganhou dimensão nacional e se espalhou por outros Estados brasileiros. Entre 1962/63, forças de direita tentaram sufocar o movimento e houve uma mobilização nacional em sua defesa: até mesmo o então Ministro da Educação, Darci Ribeiro, foi ao Recife apoiar pessoalmente o MCP e o considerou "um exemplo a ser levado a todo o País". Com o golpe militar de 1964, o MCP foi extinto.

Este conjunto de fatores apresentados compunha, juntamente com outros, tanto de ordem nacional quanto internacional, um cenário que aparentava aos que detinham o poder no país, um quadro ameaçador.

Jango saiu do Brasil pela fronteira do Paraguai dando início ao longo período da Ditadura Militar. Segundo Dreyfuss, é importante frisar que o golpe de 1964 foi civil-militar e teve, como um de seus mais eficientes protagonistas, um aparelho político e ideológico da sociedade civil brasileira nos anos 1960.

Por outro lado o desagrado da sociedade, onde cartunistas e humoristas expressavam a insatisfação que tomava conta de grande parte das pessoas, representantes de segmentos sociais começavam a ensaiar organizações clandestinas. 
A crise política no país se arrastava desde a renúncia de Jânio Quadros em 1961. João Goulart, seu vice, assumiu a presidência num clima político infausto. Com a abdicação de Jânio, em 25 de agosto de 1961, os ministros da Guerra, Aeronáutica e Marinha lançaram manifesto onde declaravam não aceitar a substituição de Jânio pelo seu vice, João Goulart, que na ocasião se encontrava em viagem à China.

Como solução para a crise política, o Congresso Nacional aprovou a Emenda Constitucional número 4/61 que, instituindo o sistema parlamentar de governo, garantiu a posse de Goulart, dando-lhe a chefia do Estado, mas não a do governo. A referida emenda estabeleceu que a lei poderia dispor "sobre a realização de plebiscito que decida da manutenção do sistema parlamentar ou a volta do sistema presidencial, devendo, em tal hipótese, fazer-se a consulta plebiscitária nove meses antes do termo do atual período presidencial."

Deste modo, a consulta deveria realizar-se, então, em 1965. Ocorre que, em 16 de setembro de 1962, o Congresso aprovou a Lei Complementar no. 2, antecipando a consulta para 6 de janeiro de 1963 e chamando-a de referendo. Mais de nove milhões de eleitores escolheram o retorno ao sistema presidencialista - restabelecido pela Emenda Constitucional número 6/63 - contra pouco mais de dois milhões de eleitores que optaram pela manutenção do sistema parlamentarista.

O governo de João Goulart foi marcado pela abertura às organizações sociais. Estudantes, organizações populares e trabalhadores ganharam espaço, causando preocupação nas classes conservadoras como, por exemplo, parte dos empresários e banqueiros, setores da Igreja Católica, dos militares e da classe média.

Os partidos de oposição, como a UDN (União Democrática nacional) e o PSD (Partido Social Democrático), acusavam Jango de estar planejando um golpe de esquerda e de ser responsável pela carestia e inflação que o Brasil enfrentava.

No dia 13 de Março de 1964, João Goulart realizou um grande comício na Central do Brasil, Rio de Janeiro, onde defendeu as Reformas de Base. Neste plano 
Goulart prometia mudanças radicais na estrutura agrária, econômica e educacional no país. Seis dias depois, os conservadores realizaram uma manifestação contra as intenções de Jango. A Marcha da Família com Deus e pela Liberdade reuniu milhares de pessoas pelas ruas do centro da cidade de São Paulo.

O clima de crise política e as tensões sociais aumentavam a cada dia. Na madrugada de 31 de março de 1964, tropas militares sob o comando do general Olimpio Mourão Filho marcharam de Juiz de Fora para o Rio de Janeiro, com o objetivo de depor o governo, legalmente constituído, de João Goulart. ${ }^{28}$ O presidente encontrava-se no Rio de Janeiro quando recebeu um manifesto exigindo sua renúncia. O chefe da Casa Militar, general Assis Brasil, não conseguiu colocar em prática um plano que teria a função de impedir um possível golpe. O presidente seguiu para Porto Alegre, sua terra natal.

O Congresso nacional declarou, no dia 2 de Abril, vaga a Presidência da República e deu posse ao Presidente da Câmara dos Deputados, Ranieri Mazzili, que permaneceu no cargo até 15 de Abril representando um papel meramente decorativo: o governo era exercido pelos ministros militares.

Na história republicana brasileira ocorreram diversas intervenções militares de curta duração. Desta vez, porém, o país foi surpreendido por cenas de força e violência: tanques, caminhões e jipes de guerra ocuparam as ruas das principais cidades brasileiras. Sedes de partidos políticos, associações e sindicatos dos movimentos que apoiavam as reformas foram tomadas por soldados fortemente armados.

A Junta Militar, que assumiu o governo provisoriamente, era composta pelo general Artur da Costa e Silva, o almirante Augusto Rademaker e o brigadeiro Francisco Correia de Melo. A primeira medida tomada pelo grupo militar foi a decretação do Ato Institucional $\mathrm{n}^{\circ}$ 1. (AI - 1). Em seu texto estava prevista a realização de eleições para outubro de 1965. No entanto, essa mesma Junta contrariou seu decreto impondo a indicação de Castello Branco.

${ }^{28}$ MURICY,C. Imprensa Oficial, Pernambuco, 1985. 
Entre outras medidas, o novo governo estabeleceu a nacionalização do setor petrolífero, a proibição da desapropriação de terras, a cassação dos direitos políticos de alguns parlamentares e ex-presidentes, o rompimento das relações com Cuba e a investigação contra os opositores ao governo. Os quadros ministeriais de Castello Branco foram compostos por antigas figuras políticas do UDN e do PSD, e dos pensadores da Escola Superior de Guerra, também conhecido como "grupo da Sorbonne". (OLIVEIRA.1976)

Os movimentos estudantis e a União Nacional dos Estudantes foram colocados na ilegalidade. Os centros de ensino superior do país passaram a ser constantemente vistoriados por autoridades do regime militar. Em 1965, o Ministério da Educação e Cultura estabeleceu a reformulação das grades curriculares no ensino médio e superior. Os estudantes não teriam mais direito de participação nas questões administrativas nas faculdades.

Os trabalhadores também sofreram grande pressão do governo de Castello Branco com a intervenção militar em diversos sindicatos. Na zona rural, a ascendente Liga Camponesa, liderada por Francisco Julião, foi colocada na ilegalidade. Os meios de comunicação ainda tinham uma autonomia relativa. Nos jornais ainda saíam algumas notícias denunciando as prisões arbitrárias e a prática de tortura. No entanto, essa liberdade refletiva dos meios de comunicação logo foi cerceada.(CASTRO.1994)

A luta contra a desordem que justificava a intervenção militar logo sofreu outras frentes de oposição. No ano de 1966, os partidos contrários à ditadura conseguiram eleger governadores no Rio de Janeiro e Minas Gerais. A potencial oposição política forçou a imposição do Ato Institucional $\mathrm{n}^{\circ}$ 2. De acordo com essa medida, todos os partidos foram postos na ilegalidade, restando apenas duas novas legendas: o MDB (Movimento Democrático Brasileiro) e o ARENA (Aliança Renovadora Nacional).

Parte da população brasileira logo reagiu contra as arbitrariedades dos militares. Várias passeatas, manifestações e mobilizações estudantis tomavam as ruas 
exigindo o fim da ditadura. Em resposta, os militares colocavam os seus soldados para rebater violentamente aos protestos. Logo em seguida, novos atos institucionais foram decretados com o objetivo de refrear as vias de oposição institucional e popular.

Em janeiro de 1966, o Ato Institucional número 3 estabelecia a eleição indireta para a escolha dos governadores estaduais. Os prefeitos dos grandes centros urbanos só poderiam chegar ao poder através da nomeação dos governadores. Além disso, o regime militar poderia decretar Estado de Sítio sem a aprovação prévia do Congresso Nacional. Dessa forma, o Poder Executivo Federal ganhava amplos poderes de atuação política.

No plano econômico os militares preocuparam em combater o galopante processo inflacionário que, na época, atingia os 100\% anuais. Dessa forma, o regime ditatorial apoiou a abertura da economia para que empresas estrangeiras reaquecessem o setor produtivo brasileiro. Além disso, o funcionalismo público, o salário mínimo e as linhas de crédito foram imediatamente controlados ou reduzidos.(DREYFUSS.1981)

Ao fim do mandato de Castello Branco, uma nova carta constitucional foi redigida para o país. Nela o princípio federalista, que conferia autonomia aos poderes estaduais, foi nitidamente enfraquecido. As novas Leis de Imprensa e Segurança Nacional censuravam as liberdades democráticas sobre o pretexto de controlar os "inimigos internos" da nação. A escolha do presidente ficava a cargo do Congresso Nacional, que cooptados pela pressão dos militares elegia os candidatos de seu interesse. Em 1967 foi instituída a sexta Constituição do Brasil e a quinta da República. Ela institucionalizava e legalizava o regime militar, aumentava a influência do Poder Executivo sobre o Legislativo e Judiciário, criando desta forma, uma hierarquia constitucional centralizadora. As emendas constitucionais que eram atribuições do Legislativo, com o aval do Executivo e Judiciário, passaram a ser únicas e exclusivas dos que exerciam o Poder Executivo, ficando os demais relevados a expectadores das aprovações dos "pacotes", como foram, posteriormente, nominadas as emendas e legislações baixadas pelo presidente da república. 
A referida Constituição recebeu em 1969 nova redação por uma emenda decretada pelos "Ministros militares no exercício da Presidência da República" por ocasião da doença do Presidente Costa e Silva. A Emenda número 1 intensificou a concentração de poder no Executivo dominado pelo Exército, decretou a Lei de Segurança Nacional, instituiu uma Lei de Imprensa que estabeleceu a Censura Federal e, junto com mais um Ato Institucional, permitiu a substituição do presidente doente por uma Junta Militar, apesar de existir o vice-presidente, Pedro Aleixo, que era civil.

Era necessário, porém, que um novo presidente para o país. Entre os membros do oficialato mais cotados para assumir o cargo em aberto, destacava-se o general Albuquerque Lima, uma das mais proeminentes figuras entre os oficiais mais jovens do Exército. No entanto, os grupos mais ligados à chamada "linha dura" 29 acabaram aprovando o nome de Emílio Garrastazu Médici.

No governo Médici, que ficou conhecido com "os anos negros da Ditadura", observou-se o auge da ação dos instrumentos de repressão e tortura instalados a partir de 1968. Os famosos "porões da ditadura" ganhavam o aval do Estado para promover a tortura e o assassinato no interior de delegacias e presídios. A guerrilha, que usou de violência contra o regime, foi seriamente abalada com o assassinato de Carlos Lamarca e Carlos Marighella. A Guerrilha do Araguaia, findada em 1975, foi uma das poucas atividades de oposição clandestina a resistir (CASTRO. ARAÚJO. 1994).

A repressão aos órgãos de imprensa foi intensa, impossibilitando a denúncia das arbitrariedades que se espalhavam pelo país. Ao mesmo tempo, no governo de Médici observou-se o uso maciço dos meios de comunicação para instituir uma visão positiva sobre o Governo Militar. A campanha publicitária oficial espalhava adesivos

\footnotetext{
${ }^{29}$ Linha-dura é um termo usado em política para designar uma corrente ou facção, dentro de um movimento, partido ou governo, que adota posições mais radicais, menos moderadas e mais intolerantes, especialmente no contexto de regimes autoritários.
} 
e cartazes defendendo o ufanismo nacionalista. Palavras de ordem e cooperação como “Brasil, Ame ou deixe-o" integravam o discurso político da época. ${ }^{30}$

A eficiência desta propaganda foi alcançada graças a um conjunto de medidas econômicas instituídas pelo Ministro Delfim Neto. Influenciado por uma perspectiva econômica de natureza produtivista, Delfim Neto incentivou o reaquecimento das atividades econômicas sem o repasse destas riquezas à sociedade. Conforme ele mesmo dizia, era preciso fazer o bolo crescer antes de ser repartido. Em curto prazo, seu plano de ação se traduziu em índices de crescimento superiores a 10\% por cento ao ano.

O chamado "milagre econômico" foi marcado pela realização de grandes obras da iniciativa pública. Obras de porte faraônico como a rodovia Transamazônica, a ponte Rio-Niterói e Usina Hidrelétrica de Itaipu passavam a impressão de um país que se modernizava a passos largos. Entretanto, a euforia desenvolvimentista era custeada por meio de enormes quantidades de dinheiro obtidas por meio de empréstimos que alcançaram a cifra dos 10 milhões de dólares. ${ }^{31}$

A participação do Estado na economia ampliou-se significativamente com a criação de aproximadamente trezentas empresas estatais entre os anos de 1974 e 1979. Diversas agências de ação política organizavam o desenvolvimento dos setores econômico e social. O Instituto Nacional de Colonização e Reforma Agrária (INCRA), o Movimento Brasileiro de Alfabetização (MOBRAL) e o Plano de Integração Social (PIS) formavam alguns dos "braços" da ação política dos militares. (DREYFUSS,1981)

A expansão do setor industrial, viabilizada por meio da expansão do crédito, a manutenção dos índices salariais e a repressão política, incitou uma explosão consumista entre os setores médios da população. A obtenção de uma casa própria financiada, a compra de um carro e as compras no shopping começaram a ser os principais "sonhos de consumo" da classe média.

30 Ver: FICO, Carlos. A propaganda da ditadura. In:Reinventando o otimismo. Ditadura, propaganda e imaginário social no Brasil. Rio de Janeiro, Ed. Fundação Getúlio Vargas, 1997.

31 Ver: PRADO \&EARP. O "milagre" brasileiro: crescimento acelerado, integração internacional e concentração de renda (1967-1973). In: FERREIRA \& DELGADO (orgs.)O Brasil republicano. O tempo da Ditadura. Editora Civilização Brasileira, Rio de Janeiro, 2003. 
Entretanto, “o milagre” se esvaiu com a mesma velocidade que empolgou. No ano de 1973, uma crise internacional do petróleo escancarou as fraquezas da economia dando fim a toda empolgação. Na época, o Brasil importava mais da metade dos combustíveis que produzia e, por isso, não resistiu ao impacto causado pela alta nos preços do petróleo. Em pouco tempo, a dívida externa e a onda inflacionária acabou com os sucessos do regime.

O Governo de Ernesto Geisel foi marcado pela necessidade de se administrar o avanço das oposições legais frente os sinais de crise da ditadura. O processo de eleição do novo presidente foi marcado por eleições indiretas onde o MDB lançou os nomes de Ulysses Guimarães e Barbosa Lima Sobrinho enquanto “concorrentes” do candidato do ARENA. Mesmo sabendo que não chegariam ao poder, a chapa do MDB correu em campanha denunciado as falhas do regime militar e a opressão do sistema.

Em face aos problemas enfrentados naquela época, o governo Geisel convocou Mario Henrique Simonsen para assumir o Ministério da Fazenda. Anunciado o II Plano Nacional de Desenvolvimento (II-PND), o governo buscava conciliar a retomada do crescimento econômico com a contenção da onda inflacionária. Dando prioridade ao desenvolvimento de bens de capital, o novo governo investiu principalmente nas empresas estatais.

Entretanto, as reformas não repercutiam o efeito esperado, pois a economia nacional não tinha condições próprias para se recuperar de seus problemas. Assim como o Brasil sofreu os efeitos da crise do petróleo, as grandes potências econômicas também passavam por um momento de retração generalizada. Em meio a uma economia enfraquecida, os setores de oposição política oficial ganhavam maior força de atuação política.

A busca por reformas foi sentida nas eleições parlamentares de 1974, onde mais de $40 \%$ das cadeiras do Congresso Nacional foram ocupadas por integrantes do MDB. Os militares da chamada "linha dura" começaram a perceber a desaprovação popular frente o regime. Em contrapartida, outros integrantes do regime defendiam 
a necessidade de flexibilização que pudesse dar maior longevidade ao governo militar.

O contexto marcado por contradições acabou incitando os setores mais radicais do regime a cometerem atos de extremo autoritarismo. Em outubro de 1975, o jornalista Vladimir Herzog foi assassinado nos corredores do II Exército de São Paulo. Segundo as fontes oficiais, o jornalista teria se matado na prisão. No entanto, as fotos do incidente estranhamente mostravam seu pescoço amarrado a um lençol e com os pés ao chão. 32

O episódio acabou dando forças para que diversas entidades representativas se unissem em torno de duas grandes reivindicações: a anistia aos presos políticos e a realização de uma nova Constituinte. Entre as entidades que encabeçaram essas lutas se destacavam a Ordem dos Advogados do Brasil, a Associação Brasileira para o Progresso da Ciência, a Associação Brasileira de Imprensa, Comitê Brasileiro pela Anistia, as Comunidades Eclesiais de Base e a União dos Estudantes do Brasil.

Projetando uma ampliação da representação política dos setores de oposição, o Governo Geisel lançou, em 1977, o chamado pacote de abril. Esse pacote promoveu uma desarticulação política sustentada pelas premissas estabelecidas pelo Ato Institucional $\mathrm{n}^{\mathrm{o}} 5$ (AI-5). O Congresso Nacional foi fechado, ao mesmo tempo, o sistema judiciário e a legislação foram alterados. As campanhas eleitorais foram restritas, o mandato presidencial passou para seis anos e as leis seriam aprovadas por maioria simples.

Com isso, a ditadura conseguiu garantir uma maioria de integrantes políticos favoráveis à situação. Reafirmando seu projeto de reabertura política “lenta e gradual", o general Geisel afastou os radicais do governo para abrir portas à eleição de João Batista Figueiredo. Ao fim de seu mandato, Ernesto Geisel tomou uma última atitude que representou bem o tom conservador de sua abertura política: revogou o AI-5 e, logo em seguida, deu ao próximo presidente o direito de decretar Estado de Sítio a qualquer momento. 
O governo de João Baptista Figueiredo (1979-1985), o último presidente do regime militar, marca o início do processo de redemocratização política do Brasil. Figueiredo era chefe do SNI (Serviço Nacional de Inteligência) quando foi indicado pela Arena para a Presidência.

Um ano antes da eleição indireta em 1978, integrantes da linha-dura do Exército articulavam para que o general Sílvio Frota, ministro da Guerra, assumisse o posto. Geisel, no entanto, destituiu Frota do Ministério e fez valer sua vontade.

Em 14 de outubro, motivado pelos resultados eleitorais para o Congresso Nacional, o MDB decidiu disputar as eleições com o general Euler Bentes. Figueiredo e seu vice, Aureliano Chaves, no entanto, venceram com 355 votos, contra 266 de Bentes. No mês seguinte, nas eleições parlamentares, o MDB conseguiu a maioria dos votos da população, mas Arena permaneceu com maioria no Congresso, por causa do Pacote de Abril.

Figueiredo assumiu o governo em um contexto de aceleração da inflação, baixos salários e de pouca distribuição de renda. Começaram a surgir diversas greves, contrariando o que determinavam os militares. Figueiredo não conseguia por fim às manifestações, disseminadas por todo país. ${ }^{33}$

Essas manifestações criaram clima de agito político e luta pela democracia. Juntou-se a elas, além dos votos de protesto no MDB, a Campanha Nacional PróAnistia, que reuniu milhares de pessoas pedindo o retorno dos condenados por crimes políticos durante o regime militar. Figueiredo cedeu às pressões e começaram a voltar ao Brasil os exilados pela ditadura.

No mesmo ano, Figueiredo promoveu uma reforma que acabou com o sistema bipartidário e, consequentemente, com o MDB e a Arena. A idéia dos militares era enfraquecer o MDB. As forças progressistas foram divididas em vários partidos, 
PMDB, PTB, PDT, PP e PT, enquanto a Arena se concentrou no PDS. Decretou, também eleições diretas para os Estados a partir de 1980.34

A série de avanços políticos provocou reação da direita reacionária. Civis e militares desses segmentos começaram praticar seqüestros e atos com bomba e a pôr fogo em bancas que vendiam publicações consideradas por eles subversivas (o jornal "O Pasquim", com suas sátiras ao regime militar e seu humor ácido, era um exemplo).

Em São Paulo, o jurista Dalmo Dallari ficou em cativeiro e foi espancando, e, no Rio de Janeiro, foi colocada uma bomba na sede da OAB (Ordem dos Advogados do Brasil) e outra na sala do vereador do PMDB, Antonio Carlos Carvalho, que matou um assessor técnico e tio do legislador municipal.

Em de abril de 1981, os atos violentos atingiram o clímax, com o episódio Riocentro. Durante um show comemorativo do Dia do Trabalho, com cerca de 20 mil pessoas e organizado por entidades sindicais, uma bomba foi encontrada na caixa de força e outra explodiu em um carro estacionado no local, matando um sargento do Exército e ferindo um capitão.

Diante do clamor público, o chefe do Gabinete Civil da Presidência, o general Golbery do Couto e Silva, tentou agilizar as investigações e fazê-las seguir pela Justiça comum. Golbery acabou se demitindo em agosto de 1981, após pressão das Forças Armadas. O Exército negou envolvimento, e o processo foi sendo retardado em todas as instâncias até ser arquivado anos depois.

Em 1982, as eleições fizeram da oposição a grande vitoriosa. Além da maioria no Congresso, conseguiu o governo de Estados importantes. Em São Paulo, ganhou Franco Montoro (PMDB) e, no Rio de Janeiro, Leonel Brizola (PDT).

O ambiente político propiciou em 1983 a apresentação pelo deputado federal Dante de Oliveira (PMDB-MT) de uma emenda constitucional que previa a eleição direta para presidente no ano seguinte. Ela novamente mobilizou a população a ir às ruas e pedir a volta da democracia. No início de 1984, cerca de 500 mil pessoas foram

\footnotetext{
${ }^{34}$ Ver MOTTA. Introdução à história dos partidos políticos brasileiros. Editora UFMG. Belo Horizonte, 1999.
} 
a um comício na Candelária, no centro do Rio. Em São Paulo, cerca de 1,7 milhão foram ao vale do Anhangabaú, na maior manifestação da história brasileira até então.

Os comícios contavam com as presenças de artistas e lideranças políticas, como Ulysses Guimarães, Montoro, Fernando Henrique Cardoso, Mário Covas, Lula, Teotônio Vilela, Barbosa Lima Sobrinho, Brizola, entre outros.

Figueiredo exprimiu as dificuldades de manter o regime militar com uma frase já no final de seu mandato: “Quero que me esqueçam”. Foi nesse contexto, dos anos 1950/1960 que nasceu e sofreu a intervenção dos militares a Faculdade Isolada de São José do Rio Preto.

\section{Educação e Regime Militar}

Uma análise da educação ao longo dos 21 anos de ditadura militar deixa traduzir de forma bastante límpida uma das grandes contradições do regime: produzir mecanismos de desenvolvimento acelerado de acumulação de capital e garantir, simultaneamente, o acesso da população aos direitos de bem-estar social. Esse impasse não encontrou solução, e os direitos de bem-estar foram sacrificados em nome do desenvolvimento acelerado( FÁVERO.1996)

Grandes modificações foram feitas no setor educacional. Reformaram-se os três níveis de ensino (fundamental, médio e superior), expandiu-se a rede física e o número de vagas nos estabelecimentos escolares. Durante a ditadura o Brasil, começou a formar uma pequena, mas expressiva, elite universitária, desenvolvendo pesquisas de ponta; os resultados do surgimento dessa elite podem ser verificados hoje, através de pesquisas em áreas nas quais o Brasil ganhou destaque internacional, como é o caso da engenharia genética, valendo ao país a participação no projeto Genoma.

Enquanto se formava a pequena elite intelectual, milhões de brasileiros continuavam analfabetos e, a cada ano, milhares de crianças não conseguiam ter acesso à escolarização básica. Milhares de jovens deixavam a escola para ingressar no mercado de trabalho. Alguns outros, heroicamente, conseguiam freqüentar as aulas no período noturno e alguns poucos conseguiam chegar à universidade. 
A educação foi uma das grandes preocupações dos grupos que atuaram no âmbito do Estado após 1964, pois o regime necessitava, tanto de técnicos altamente qualificados quanto de mão-de-obra desqualificada. Mão-de-obra desqualificada e "dócil". A rede física foi expandida, um maior número de pessoas pôde freqüentar a escola e nela aprendiam que o Brasil era um país democrático, católico e alinhado ao mundo Ocidental (CUNHA.1977).

O investimento em educação, porém, não permitia que se absorvesse toda a demanda escolar. Os recursos para a educação foram minguando ao longo do período ditatorial, pois a prioridade do regime era o desenvolvimento acelerado.

O regime tencionava construir um sistema de ensino que fosse capaz de aplacar a pobreza no Brasil, diminuindo a desigualdade social. Como diminuir a desigualdade num modelo de desenvolvimento econômico que priorizava o enriquecimento da camada mais rica da população? Essa pergunta não encontrou resposta nos planejamentos educacionais desenvolvidos entre 1964 e 1985; a desigualdade social não diminuiu, ao contrário, aprofundou-se(GERMANO.1994).

O setor educacional foi alvo constante dos ataques do governo. Qualquer forma de discordância era logo taxada de "subversiva" ou "comunista", e seu autor era banido dos meios acadêmicos. O movimento estudantil sofreu muitas baixas, até que perdeu sua força, mantendo-se quase inerte nos anos mais truculentos da ditadura. Essa foi a outra forma de educar encontrada pelo regime: disseminando o terror, para desencorajar atitudes de apoio ao "subversivos" ou "comunistas". 35

A educação funcionou durante a ditadura militar como uma estratégia de hegemonia. O regime procurou difundir seus ideais através da escola, buscando o apoio de setores da sociedade para seu projeto de desenvolvimento, simultaneamente ao alargamento controlado das possibilidades de acesso ao ensino pelas camadas mais pobres.

Divulgou conceitos produzidos pela Escola Superior de Guerra nos manuais de Estudos dos Problemas Brasileiros, instrumentalizando os privilegiados que tinham

\footnotetext{
${ }^{35}$ Ver: ALVES. Estado e Oposição no Brasil 1964-1984. EDUSC. Bauru, São Paulo, 2005.
} 
acesso ao ensino superior no combate aos "inimigos internos", na "defesa da Pátria" e na "preservação dos valores nacionais".

Após 21 anos de ditadura militar, restou ao Brasil um sistema educacional com graves problemas: uma estrutura física que, apesar de estendida, não foi suficiente para atender à demanda crescente; uma queda na qualidade do ensino superior, com a proliferação de "empresas educacionais" que permitiram o acesso de um pequeno contingente das camadas de menores níveis de renda ao ensino superior, contingente este que custeava seus próprios estudos; queda na qualidade dos níveis elementares de ensino, dada a queda na qualidade de formação dos profissionais de educação, além da depreciação das condições de trabalho desses profissionais (MECHI,2006). 


\section{HISTORIOGRAFIA}

O Brasil mergulhou de 1964 a 1985 em um dos períodos mais difíceis de sua História. Durante 21 anos o país viveu um regime que marcou a nação, seu povo e suas instituições. Foram 20 anos de confronto entre forças políticas e sociais. Nesse período, tanto governo como oposição, lutaram acirradamente e utilizaram todos os seus recursos para ganhar a luta e o poder. Utilizou-se largamente a censura, o terrorismo, a tortura e a guerrilha.

A memória dessa época adquiriu um significado, na maioria das vezes, obscuro. O Regime Militar é o reino da exceção, os anos que ele durou são chamados anos de chumbo.

Têm-se percebido um crescente interesse de historiadores e estudantes de graduação pelos temas do período 1964-1985. Ouso dizer que se trata de um movimento de incorporação, pelos historiadores, de temáticas outrora teorizadas quase exclusivamente por cientistas políticos e sociólogos. A produção historiográfica sobre o golpe de 64 e o regime que o sucedeu, ficou marcada em uma primeira fase por dois gêneros importantes. O primeiro foi inspirado na vertente norte-americana produzido pelos brazilianists ${ }^{36}$, que buscava explicar e classificar, em temos quase nominalistas, as crises militares de países como o Brasil. Seriam os militares uma instituição autônoma ou estariam a serviço de determinados grupos sociais? Os regimes militares latino-americanos poderiam ser explicados pelo mesmo modelo teórico? O caso brasileiro seria diferente de todos os outros? Esses debates produziram uma bibliografia bastante intensa que são contribuições significativas para o entendimento do Golpe.

36 A partir de 1964 vieram ao Brasil algumas dezenas de acadêmicos americanos para estudar nossa história, economia, os militares, a situação política. Foram chamados de "brazilianistas" . Alguns, como o economista Albert Fishlow, produziram as primeiras contestações à mistificação designada como "Milagre Brasileiro". Hoje chefiam departamentos das mais importantes universidades americanas (caso de Alfred Stepan, Thomas Skidmore etc.).Para ver mais: A colônia brasilianista de José Carlos Sebe Bom Meihy. 
O segundo gênero foi a memorialística, que cresceu, sobretudo á partir do Governo Geisel. Foi, de algum modo, a primeira tentativa de construção de uma narrativa histórica sobre o período.

Há várias interpretações para o Golpe, e o período imediato que o antecedeu costuma ser tratado pelas variáveis sociais, políticas e econômicas. Encontramos estudos que dão ênfase à quebra do pacto populista e seus desdobramentos e a chamada "questão militar" que surgiu nos fins da década de 1950. Outros estudos dedicam-se à questão das "massas", à problemática da crise político-partidária e outros ainda consagram-se a aspectos de caráter mais estrutural, ligados às condições de desempenho da economia brasileira herdadas do Plano de Metas (MENDONÇA.1994).

A produção histórica que marca a nova fase de estudos sobre a ditadura militar possui suas especificidades. Desse modo, para o historiador, a partir dos anos 80, verifica-se no Brasil a busca de outros padrões de narratividade que não fosse o marxismo, mas também não passasse pela pretensão rankeana de mostrar "o que realmente aconteceu". Surgiu, então, um novo padrão de narratividade que estava baseado na estratégia cognitiva da valorização da subjetividade, do cotidiano, através de versões verossímeis que não almejavam firmarem-se como verdade absolutas, concatenadas, e sim, quanto possível, em narrativas na voz dos sujeitos que participaram ativamente desse período e sofreram punições por isso.Essas narrativas permitem novas análises e compreensão de questões até então sem espaço na historiografia. Esta é a linha de estudos adotada por esse trabalho.

Essa nova linha explica, talvez, a grande quantidade de trabalhos sobre o tema cultura durante o regime militar. ${ }^{37}$ A Nova História envolve inúmeras correntes,

37 De acordo com Peter Burke, a Nova História diferencia-se da tradicional em seis pontos: o paradigma tradicional diz respeito somente à história política, a Nova História, como dito anteriormente, preocupa-se com uma história total, onde tudo é histórico; a história tradicional pensa na história como narração dos grandes fatos, a nova preocupa-se em analisar as estruturas; a tradicional olha de cima, a nova, de cima, de baixo e de outros ângulos possíveis; documentos oficiais são os que interessam ao paradigma tradicional, o paradigma da Nova História aceita qualquer espécie de documento; o historiador tradicional explica por meio da vontade do indivíduo histórico, a Nova História preocupa-se com os movimentos sociais, as tendências; e, finalmente, o paradigma tradicional considera a História uma ciência objetiva, o paradigma novo não crê na possibilidade de uma objetividade total. 
algumas discrepantes entre si. Porém, não se pode negar que foi nesse contexto que os estudos históricos sobre o período 1964-1985 se avolumaram. Em uma breve reflexão sobre as principais teses que explicam o fenômeno do Golpe, podemos dizer que os trabalhos mais sólidos podem ser agrupados em três correntes: as tentativas de teorização da Ciência Política, as análises marxistas e a valorização do papel dos militares. Existem vários autores que têm escrito e estudado os mais variados aspectos sobre o Regime Militar: Élio Gaspari, Carlos Fico, Maria Celina D'Araujo, Celso Castro e Gláucio Soares, Daniel Aarão Reis, Marcelo Ridenti, Rodrigo Sá Mota, Maria Helena Moreira Alves,Heloisa Buarque de Hollanda, Marcos Augusto Gonçalves, Carlos Fico, Renato Ortiz, Roberto Schwarz, Jacob Gorender entre vários outros. Entre a extensa bibliografia sobre o período (em geral) destaco algumas obras que considero dialogar com o meu trabalho e que foram úteis para estabelecer a análise das entrevistas. Sobre intervenções em outras instituições de ensino, priorizei:

- O Livro Negro da USP, o controle ideológico sobre a universidade, Associação dos Docentes da Universidade de São Paulo em 1978, São Paulo, sendo que esta é a única publicação encontrada que aborda, ainda que brevemente, a invasão, em São José do Rio Preto, porém, em face à analise pormenorizada do ataque à USP e das questões políticas internas também presentes nesse texto, é possível entender melhor o caso Rio Preto.

. Heloisa Buarque de Holanda escreveu o livro Cultura e participação nos anos 60. Nele se encontra uma descrição do panorama cultural brasileiro nos anos 60, situação oportuna para alimentar debates em nosso trabalho, uma vez que, como esclareceremos a seguir, na faculdade de Rio Preto havia um grupo de teatro amador (GRUTA) e uma célula do MCP (Movimento de Cultura Popular) muito atuantes.

- Ainda sobre cultura nos anos de 1960 e mais especificamente sobre o MPC (Movimento Popular de Cultura), Renato Ortiz analisa em Cultura Brasileira e Identidade Nacional, a questão do nacional e do popular na cultura brasileira. O autor procura mostrar que a identidade nacional está profundamente ligada a uma reinterpretação do popular pelos grupos sociais e à própria construção do Estado 
brasileiro, Não existe, assim, uma identidade autêntica, mas uma pluralidade de identidades, construídas por diferentes grupos sociais em diferentes momentos históricos.

. Por constituir um amplo balanço e avaliação dos estudos sobre o Golpe de 64, deve ser destacado o livro do historiador Carlos Fico, Além do Golpe. Versões e controvérsias sobre 1964 e a ditadura militar, Ed. Record, 2004, Rio de Janeiro. O autor discute as principais interpretações sobre o golpe e o regime militar. $O$ principal objetivo do livro de Carlos Fico é expor e discutir as mais importantes correntes da historiografia sobre o Golpe de 1964 e confrontar algumas questões controvertidas sobre repressão política, censura e outros temas da ditadura militar. O livro Além do Golpe faz uma análise precisa das inúmeras correntes historiográficas sobre o Golpe de 64. A seleção de documentos históricos que ele apresenta é muito esclarecedora. São 75 textos na integra. Mergulhar na leitura desses textos nos transporta para os anos 60 e personagens da História como Carlos Lacerda, Juscelino Kubitschek, Leonel Brizola e João Goulart. Ao longo da leitura o leitor vai construindo seu próprio olhar sobre a revolução de 64. O professor Fico divulga em seu trabalho, também, uma seleção de mais de 1100 títulos bibliográficos classificados por temas.

. Roberto Schwarz em O pai de família e outros estudos, Paz e Terra, 1992, São Paulo, procede a uma análise sobre a derrota política da esquerdas brasileiras na conjuntura de 1964, apontando e questionando os erros e equívocos das mesmas . ]

Nessa mesma direção encontramos Jacob Gorender, Combate nas Trevas. A partir de sua vivência e recordações, mas, sobretudo, de uma vasta pesquisa em livros, documentos de organizações e da realização de dezenas de entrevistas, o autor reconstrói a trajetória dos partidos e grupos de esquerda, sobretudo no período que vai de 1964 até 1974, ano em que a esquerda brasileira se encontrava mergulhada em sua mais grave crise, depois de ter sido esmagada pela repressão da ditadura.

- Marcelo Ridenti em O Fantasma da Revolução Brasileira, tem a preocupação de recuperar também a análise de classes e suas formas de representação, o autor parte 
para o estudo da composição social e das bases sociais das organizações e partidos de esquerda que atuaram naquele período. O período sobre a participação de operários, em particular os episódios de Osasco, assim como a participação das mulheres, exmilitares subalternos e camponeses, foi baseado nos números que aparecem nos processos movidos pela Justiça Militar. E, esses números foram enriquecidos por depoimentos de ativos militantes daquele período. Ridenti explora outros e novos ângulos. A agitação cultural-revolucionária dos anos 60 é analisada com riqueza e perspicácia, revelando contradições pouco difundidas no campo da esquerda.

- Para os estudos sobre os militares no período utilizamos as obras de Élio Gaspari composta de quatro livros: A Ditadura Envergonhada, A Ditadura Escancarada, A Ditadura Derrotada e A Ditadura Encurralada, todos editados pela Cia. Das Letras, em 2002, 2003 e 2004 respectivamente. Uma das maiores virtudes dessa obra talvez resida no seu inequívoco esclarecimento sobre a prática sistemática da tortura durante todo o regime militar.

. Outras obras que abordam as visões à esquerda e à direita militares sobre o Golpe são as de Maria Celina D'Araújo, Celso Castro e Glaucio Ary Dillon Soares, Visões do Golpe: A Memória Militar de 1964, Ed. Relume Dumará, Rio de Janeiro, 1994. Seu mérito é o de trazer a voz dos quartéis através de 12 entrevistas com oficiais que articularam o golpe, e que depois participaram do regime até o seu ocaso, sempre ocupando cargos de destaque nos governos que se sucederam até 1985.

Maria Celina D'Araujo, Gláucio Soares e Celso Castro ${ }^{38}$ colheram depoimentos de vários generais que tiveram papel importante no Golpe de 64. Nos depoimentos colhidos por esses historiadores vislumbram-se o papel central do anticomunismo na explicação dos motivos que levaram ao golpe. A visão desses militares conduz a uma leitura de um "contragolpe" ao golpe de esquerda que com certeza aconteceria. Era necessário o Golpe para impedir uma república comunista, sindicalista ou popular. Para os militares, a esquerda cometera um pecado capital 
quando quebrou os princípios da hierarquia e da disciplina militar como o apoio a revolta dos sargentos em $63^{39}$ e a dos marinheiros e fuzileiros navais em março de $1964^{40}$. Isto por si só seria motivo para a intervenção militar, segundo alguns. Por outro lado, no depoimento de Leônidas Pires Gonçalves, "A Revolução saiu sob a pressão da sociedade civil" (D'ARAUJO et al. (orgs.).2004), pois, assustados com a possibilidade da esquerda tomar o poder, a Igreja, empresários e classe média foram cúmplices do golpe.

Talvez o ponto mais interessante destes depoimentos (é assim que os autores chamam o que para mim são entrevistas), seja o fato de que o golpe apareça como o resultado de ações dispersas e isoladas (D'ARAUJO et AL. (orgs.).2004) Assim, não havia um projeto de governo entre os vencedores, sendo o mesmo moldado ao longo do exercício do poder, especialmente para conter os excessos da chamada linha dura como forma de garantir a unidade militar.

Assim, na disputa mnemônica entre a memória militar e a da esquerda, pelo menos do ponto de vista simbólico, a esquerda pode trazer à tona suas memórias de 64, derrotando assim a memória dos militares. Mesmo submetida a uma violência extrema e mantida na clandestinidade, a "memória subterrânea" 41 dos militantes de esquerda dos anos 1960-1970 soube construir uma rede simbólica e marginal na família e nos círculos que possibilitou a sua emergência no processo de democratização, denunciando as cassações, prisões e torturas a que foram submetidos.

Nas últimas duas décadas, porém, produziu-se uma rica bibliografia sobre o período militar, onde se destacam as obras acadêmicas, os ensaios memorialistas e

39 A Revolta dos Sargentos (12/9/63), aconteceu quando cerca de 600 soldados tomaram prédios públicos em Brasilia, quebrando a hierarquia com o pretexto de contestarem o direito a elegibilidade.

40 No dia 24 houve a rebelião dos marinheiros e fuzileiros navais no Sindicato dos Metalúrgicos, que demonstravam desobediência à hierarquia militar, não foi contestada por João Goulart.Goulart parecia pressentir o terreno minado onde se aventurava quando decidiu ir ao Clube do Automóvel, no dia 30, discursar para suboficiais e sargentos das Forças Armadas

41 Ver:POLLACK. Memória, Esquecimento e Silêncio. In:Estudos Históricos. Rio de Janeiro. Vol. 2, n.3, p.3-15, 1989. 
trabalhos científicos produzidos por protagonistas dos fatos. Alguns trabalhos de fôlego, como o de Maria Celina D’Araujo sintetizam e aprofundam essa produção. Outro trabalho que apresentou ao público brasileiro a história do Regime Militar sob a ótica dos militares foi o do jornalista Élio Gaspari. Num total de 4 volumes, produto de 20 anos de pesquisa em arquivos e resultado de horas de gravação de depoimentos cedidos por dois protagonistas do Golpe, Ernesto Geisel e o coronel Golbery do Couto e Silva.

Apesar de Élio Gaspari afirmar que em "nenhum momento passou por sua cabeça escrever uma história da ditadura", o ambicioso projeto constitui nos fatos um ensaio de interpretação geral do regime militar, de 1964 a 1979, centrado em uma grande questão: as razões essenciais do ingresso e da saída do regime ditatorial. 
PARTE IV

É chegada a hora.

Descem esperanças azuis e brancas,

Sobre cabeças idealistas.

(Desova Poética/Zeque Elias) 


\section{SOBRE O ENSINO SUPERIOR NO BRASIL NO SÉCULO XX}

O desenrolar do século XX permitiu uma série de avanços no Ensino Superior no Brasil. A criação da Universidade de Brasília em dezembro de 1961 que surgiu, não apenas, como a mais moderna universidade do país, mas como um divisor de águas na história das universidades do país, tanto por suas finalidades como por sua organização institucional. Nesse contexto destaca-se a posição da UNE por combater o caráter elitístico e arcaico das instituições universitárias. Uma das questões fundamentais era a proposta de participação do corpo docente e discente na administração universitária, através do critério de proporcionalidade representativa. Este mesmo projeto já estava sendo colocado em prática na FAFI de São José do Rio Preto. Outro ponto de destaque era o desejo de revogação do acordo MEC-USAID ${ }^{42}$

Os seminários da UNE sobre a Reforma Universitária no início dos anos 1960, de modo geral colocam sempre o problema da universidade articulado com as reformas de base e questões políticas mais globais.

Ainda no inicio dos anos 1960, algumas universidades, entre elas a Universidade do Brasil, elaboraram planos de reformulação estrutural. No caso da UB, o Conselho Universitário designou, em fevereiro de 1962, uma comissão especial para tratar da questão. De seus trabalhos resultou o documento Diretrizes para a Reforma da Universidade no Brasil . Em junho de 1963 essas diretrizes foram aprovadas, mas com o Golpe Militar de 1964, sua implantação é sustada. ${ }^{43}$

\footnotetext{
42 MEC USAID é a fusão das siglas Ministério da Educação (MEC) e United States Agency for International Development (USAID). Simplesmente conhecidos como acordos MEC-USAID cujo objetivo era aperfeiçoar o modelo educacional brasileiro. Isto se deu através da reforma do ensino, onde os cursos primário ( 5 anos) e ginasial (4 anos) foram fundidos, se chamando de primeiro grau, com 8 anos de duração e o curso científico fundido com o clássico passou a ser denominado segundo grau, com 3 anos de duração, e o curso universitário passou a ser denominado terceiro grau. Com essa reforma, se eliminou um ano de estudos fazendo com que o Brasil tivesse somente 11 níveis até chegar ao fim do segundo grau.

43 A respeito consultar FÁVERO, M. L. A. A UNE em tempos de autoritarismo. Rio de Janeiro: Ed. UFRJ, 1999 FÁVERO, M. L. A. A Universidade no Brasil: das origens à Reforma Universitária de 1968, Educar, Curitiba, n. 28, p. 17-36, 2006. Editora UFPR
} 


\section{NO INTERIOR...}

São José do Rio Preto ontem...(1955)

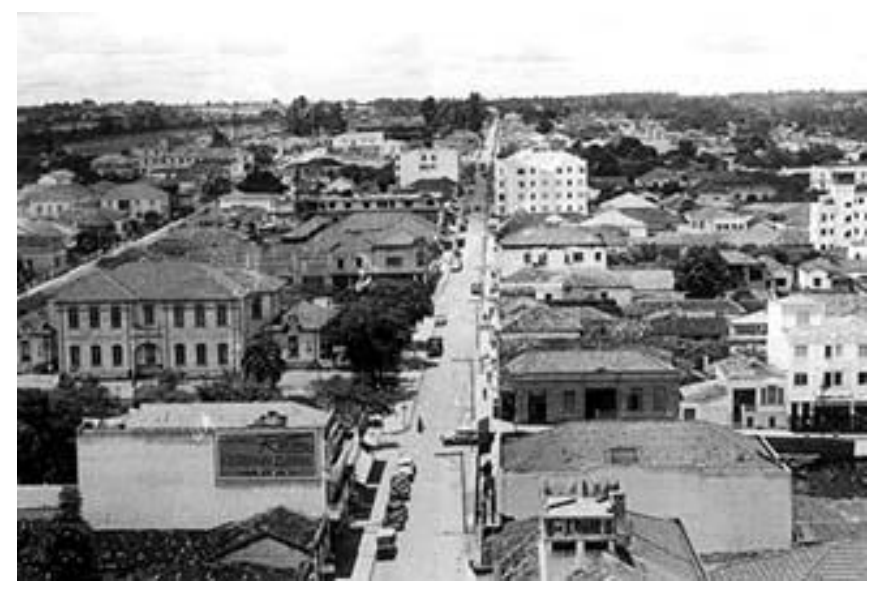

Figura 1Fonte: Globalframe - Autor: desconhecido ... e hoje. (2009)

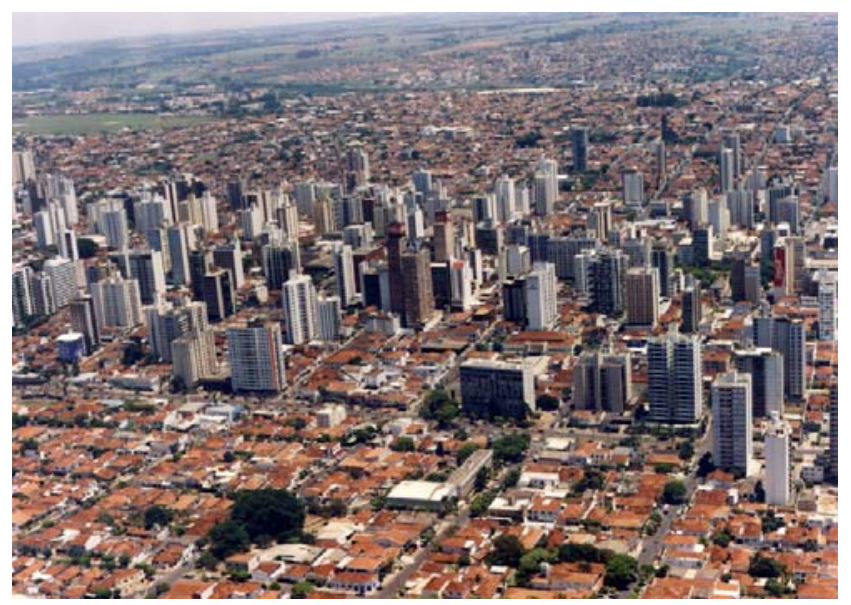

Figura 2 Fonte: Skyscrapercity. Autor: desconhecido.

Num retraço, a história de São José do Rio Preto...

Fundada em 19 de Março de 1852, sua história iniciou-se com o desbravamento e a ocupação do solo do sertão paulista em meados do século 19. A 
partir de 1840, mineiros fixaram-se e deram início à exploração agrícola e a criação de animais domésticos.

Em 1852, Luiz Antônio da Silveira doou parte de suas terras ao seu santo protetor, São José, para que o patrimônio desse origem a uma cidade. A 19 de março de 1852, João Bernardino de Seixas Ribeiro (o fundador de São José do Rio Preto), que já tinha construído uma casa de sapé nas terras do patrimônio, liderou os moradores das vizinhanças que ergueram um cruzeiro de madeira e edificaram uma pequena capela para as funções religiosas. Em 20 de março de 1855, o então Bairro de Araraquara foi elevado à categoria de Distrito de Paz e de Polícia.

No ano de 1867, o Visconde de Taunay, ao retornar da Guerra do Paraguai, pernoitou no vilarejo e registrou em seu diário o estado precário em que o mesmo se encontrava. No dia 21 de março de 1879, quando fazia parte do município de Jaboticabal, a Capela de São José é elevada à Freguesia e em 19 de julho de 1894, São José do Rio Preto foi desmembrada de Jaboticabal, transformando-se em município, pela Lei no. 294. Era um imenso território, limitando-se nos rios Paraná, Grande, Tietê e Turvo, com mais de 26 mil km2 de superfície. A presença dos rios não se esgota na fertilidade que tanto impulsionou a agricultura na região, mas expandiu-se simbolicamente como vias de acesso e penetração. ${ }^{44}$

Em 1904 (lei n 903) foi criada a comarca São José do Rio Preto. A partir de 1906 a cidade teve seu nome reduzido para Rio Preto. Somente em 1945 retomou o nome original de São José do Rio Preto. Com a chegada da Estrada de Ferro Araraquarense (EFA), em 1912, a cidade assumiu o seu destino de pólo comercial de concentração de mercadorias produzidas no então conhecido "Sertão de Avanhandava" e de irradiação de materiais vindos da capital.

A origem do nome da cidade vem da junção do padroeiro da cidade, São José, e do primeiro rio que corta o município, o Rio Preto. O tempo foi passando e em 1951, no governo de Jânio Quadros foi ampliada a Estrada de Ferro (EFA) que 
atingiu a cidade de Jales e região. São José do Rio Preto tornava-se ponte de acesso ao Triângulo Mineiro, ao Estado de Mato Grosso e Goiás, onde Juscelino Kubitschek construiu aquilo que foi seu orgulho: Brasília.

Um personagem destacava-se na política da cidade, Alberto Andaló, riopretense, foi eleito prefeito aos 40 anos, após campanha anti-ademarista . Muitos diziam que ele era franco atirador, irreverente, dinâmico, mas de total inconsistência ideológica. O que nos interessa sobre ele é que participou da criação e instalação da Faculdade de Filosofia, Ciências e Letras de São José do Rio Preto.

Desde 1953, o Professor Daud Jorge Simão, docente do Instituto de Educação Monsenhor Gonçalves, considerada a melhor escola da região, cujos professores eram muito respeitados, defendia a criação de uma faculdade em São José do Rio Preto, e o fez através de artigos publicados no Jornal "A Notícia". Recebeu amplo apoio da população e em 22 de maio do mesmo ano houve uma concentração de estudantes reivindicando escolas superiores ${ }^{45}$.

Inicialmente se propôs através da lei no. 834, a criação da Faculdade de Filosofia, Ciências e Letras, subordinada à Universidade de São Paulo na cidade, porém a iniciativa recebeu manifestação contrária do governador do Estado, Jânio Quadros.

Essa primeira decepção não abalou o sonho de uma Faculdade em São José do Rio Preto, e em 1955, um Projeto de Lei no. 30/55 da autoria do mesmo professor e também vereador Daud Jorge Simão criou a Universidade Municipal de São José do Rio Preto e o Prefeito Philadelpho Gouveia Neto promulgou, através da Lei no. 394 a criação da Universidade Municipal, que embora tenha sido criada em 1955, só foi autorizada a funcionar pelo Decreto Federal 41.061 de 1957.

Inicialmente, entre 1957 e 1958, a Faculdade funcionou com verbas municipais, era gerida por um Conselho Universitário composto por representantes profissionais 
liberais. A direção foi confiada ao Sr. Rafael Grisi, talvez porque o mesmo fosse irmão do chefe do Gabinete Civil do Governador Jânio Quadros, Sr. Décio Grisi. O corpo docente inicial foi composto por Rodolfo Azzi, Wilson Cantoni, Norman Maurice Potter, José Aloysio Reis de Andrade, Orestes Nigro e Bruna Denti, que vinham direto da USP Maria Antonia; da Universidade Nacional do Rio de Janeiro veio João Jorge Cunha; Por indicação do Prof. Celso Abade Mourão vieram Luis Dino Vizzoto e Alberto Barbosa Pinto Dias. Também foram convidados os estrangeiros Erich Arnold Von Bruggenhagen, alemão, Edoardo Querin, italiano, e o lusitano Antonio Pinto de Carvalho.

A Faculdade funcionava em uma ala com 4 salas de aula do Instituto de Educação, tinha poucos funcionários e não contava com a presença efetiva do diretor que preferia ficar em seu escritório na Rua Maria Antonia, 242, segundo ele, em busca de verbas.

Em 1958 a Faculdade transferiu-se para um local um pouco maior e já contava com um Centro Acadêmico de Filosofia. Nesse mesmo ano realizou-se uma campanha pela estadualização da Faculdade, uma vez que os recursos municipais não eram capazes de garantir as necessidades da mesma.

Como já havia uma lei estadual criando uma faculdade de Filosofia, Ciências e Letras do Estado, a empreitada ficou mais suave. Conta-se que uma comitiva de professores, alunos do CAF(Centro Acadêmico da FAFI) e o Prefeito Alberto Andaló vieram para uma audiência com o governador Jânio Quadros, na cidade de São Paulo, que inicialmente recusou-se a estadualizar a Faculdade, mas como o Prefeito Andaló não tinha papas na língua e era o maior cabo eleitoral de Jânio na Região acabou "convencendo-o" usando palavras de baixo calão e em 1959, a Faculdade de Filosofia, Ciências e Letras de São José do Rio Preto foi estadualizada, tornando-se a primeira escola desse tipo a ser mantida pelo governo de São Paulo, recebendo o nome de Faculdade Isolada de São José do Rio Preto. 
É importante ressaltar que a população de São José do Rio Preto era composta, na sua maioria por políticos tradicionais, oligárquicos, pecuaristas, agricultores, profissionais liberais e comerciantes que formavam e tinham interesse em manter uma hegemonia sobre aquela grande região. Não foi perguntado a eles que tipo de faculdade Rio Preto queria, qual modelo, com quais finalidades e no futuro essa ausência de diálogo mostrou seus resultados.

Desde o inicio da criação da Faculdade estabelecera-se uma dualidade. De um lado os professores da cidade, a maioria do Instituto de Educação Monsenhor Gonçalves, que se sentiram alijados de lecionar na Faculdade que tinham ajudado a instalar, o que provocou uma animosidade intensa aos professores que vieram da USP, chamados de "rebeldes". Estabeleceu-se também um sério embate entre professores "rebeldes" e o diretor da Faculdade, o Prof. Rafael Grisi, que era acusado por eles, entre outras coisas, de desvio de verbas. A situação ficou tão complicada que o Prof. Grisi chegou a demitir quase todos os "rebeldes" e depois por pressão dos alunos teve que readmiti-los.

Esses jovens professores vindos da USP foram estabelecendo na instituição um intenso movimento cultural com um grupo de teatro amador (GRUTA), criado pelo professor Orestes Nigro, professor da cadeira de Língua Francesa da Faculdade. O grupo foi criado, segundo o Professor Orestes, como uma alternativa cultural aos estudantes, sem nenhuma pretensão política. Para ajudar a criar o Gruta foram contatados os atores Gianfrancesco Guarnieri e Juca de Oliveira, que passaram ir à cidade encenar suas peças, promover debates com os alunos e segundo o próprio Juca de Oliveira, a intenção era criar um Teatro de Arena no interior. Naquele contexto de interpretação do "nacional-popular" e consolidação da ideologia nacionalista, atores, dramaturgos, diretores, produtores e companhias teatrais com vínculos ideológicos com o "movimento nacionalista brasileiro" procuraram, de formas diferentes, politizar e popularizar o teatro brasileiro. (GARCIA. 2004)

A fundação da companhia Teatro de Arena ocorreu em 1953, com a estréia, nos salões do Museu de Arte Moderna de São Paulo - MAM/SP, de Esta Noite É 
Nossa, de Stafford Dickens. Integraram o grupo, entre outros, José Renato, Geraldo Mateus, Henrique Becker, Sérgio Britto, Renata Blaunstein e Monah Delacy.

Ainda em 1953, produziu-se um repertório, que incluiu O Demorado Adeus, de Tennessee Williams, e Uma Mulher e Três Palhaços, de Marcel Achard, ambas sob direção de José Renato; além de Judas em Sábado de Aleluia, de Martins Pena, com direção de Sergio Britto, em 1954. As apresentações ocorreram em clubes, fábricas e salões. No final do ano foi apresentada à imprensa a sala, situada na Rua Teodoro Baima, onde foi instalado o Teatro de Arena.

Até 1956, o Arena experimentou diferentes gêneros de textos, visando compor um repertório e encontrar uma estética própria. Novo patamar foi alcançado com a fusão realizada com o Teatro Paulista dos Estudantes, TPE, e a contratação de Augusto Boal para ministrar aulas sobre as idéias de Stanislavski ao elenco e encenar Ratos e Homens, de John Steinbeck. Entre os recém- chegados estavam Gianfrancesco Guarnieri, Oduvaldo Vianna Filho, Milton Gonçalves, Vera Gertel, Flávio Migliaccio, Floramy Pinheiro, Riva Nimitz. A presença de Augusto Boal, que havia cursado dramaturgia em Nova York e conhecia os escritos de Stanislavski pela via do Actor's Studio, conduziu o grupo a um posicionamento político de esquerda. Em 1957, Juno e o Pavão, de Sean O'Casey tratou da luta do IRA, na Irlanda.

À beira da dissolução devido a uma crise financeira e ideológica, o grupo foi salvo pelo sucesso de Eles Não Usam Black-Tie, de Gianfrancesco Guarnieri, com direção de José Renato, em 1958. Vislumbrando uma fértil possibilidade aberta pelos textos nacionais, que colocavam em cena os problemas que a platéia queria ver retratados no palco, o Arena resolveu criar um Seminário de Dramaturgia e Laboratórios de Interpretação. Novos textos demandaram um novo estilo de interpretação, mais próximo dos padrões brasileiros e populares.

Entre 1958 e 1960, o Arena levou à cena diversos originais escritos pelos integrantes da companhia, num expressivo movimento de nacionalização do palco, difusão dos textos e politização da discussão da realidade nacional. Nomes como 
Paulo José, Dina Sfat, Joana Fomm, Juca de Oliveira, João José Pompeo, Lima Duarte, Myrian Muniz, Isabel Ribeiro, Dina Lisboa, Renato Consorte, entre outros, integravam o elenco estável.

Segundo o crítico Sábato Magaldi,

O Teatro de Arena de São Paulo evoca, de imediato, o abrasileiramento do nosso palco, pela imposição do autor nacional. Os Comediantes e o Teatro Brasileiro de Comédia, responsáveis pela renovação estética dos procedimentos cênicos, na década de quarenta, pautaram-se basicamente por modelos europeus. Depois de adotar, durante as primeiras temporadas, política semelhante à do TBC, o Arena definiu a sua especificidade, em 1958, a partir do lançamento de Eles Não Usam Black-Tie, de Gianfrancesco Guarnieri. A sede do Arena tornou-se, então, a casa do autor brasileiro. O êxito da tomada de posição transformou o Arena em reduto inovador, que aos poucos tirou do $\mathrm{TBC}$, e das empresas que lhe herdaram os princípios, a hegemonia da atividade dramática. De uma espécie de TBC pobre, ou econômico, o grupo evoluiu, para converter-se em porta-voz das aspirações vanguardistas de fins dos anos cinqüenta. (MAGALDI.1984)

Aos poucos e auxiliado por Juca de Oliveira e Guarnieri, O GRUTA deu inicio a uma intensa programação cultural, começando a se apresentar nas cidades da região e em outras faculdades isoladas do interior paulista como Araraquara e Assis. As atividades teatrais desse grupo, à semelhança do que ocorria no Brasil na década de 1960, se desdobraram em outros tipos de ações incorporando as artes em geral. 
Paralelamente, o Professor Franz Wilheim Heimer, alemão, militante e criador da $\mathrm{AP}^{46}$ e do MPC na região, desenvolvia um trabalho financiado por entidades alemãs ligadas à Igreja Católica para a criação de um sindicato de trabalhadores rurais em Recife, Pernambuco, e foi lá que conheceu Paulo Freire e seu método de alfabetização $^{47}$. O Professor Heimer, orientado pelo próprio Freire, não demorou a colocar em prática os novos métodos na região, inicialmente com a autorização dos proprietários das fazendas, contando também com os alunos que faziam parte do GRUTA e do CAF (Centro Acadêmico da Filosofia).

Em 1952 nasceu no Brasil a Campanha Nacional de Educação Rural, mais precisamente no governo Vargas, oficializada em 1956 no Governo Juscelino Kubitschek. Criada para funcionar em nível nacional, um de seus principais objetivos foi o de adequar os camponeses para o momento desenvolvimentista daqueles anos, valendo-se da educação fundamental, incluindo-se aí a alfabetização. (BARREIRO.1994) Acredito que, pela semelhança, tal campanha possa ter se inspirado nos estudos de Paulo Freire.

Concomitantemente outros professores como Wilson Cantoni, Mauricio Traugtenberg, Hélio Leite de Barros, entre outros, juntamente com os alunos travavam árdua luta pela melhoria do ensino público e eram entusiastas defensores da reforma universitária pretendida então pelo Presidente João Goulart. Reuniram-se Professores, o GRUTA, o CAF, a UNE (União Nacional dos Estudantes) e elaboraram

46 Constituído no seio da Juventude Universitária Católica (JUC) um núcleo radical que teve grande atuação política, que se organizou fora da JUC e depois rompeu formalmente com a Igreja. A Ação Popular foi fundada em junho de 1962, em Belo Horizonte. Seus fundadores foram Herbert José de Souza, Aldo da Silva Arantes, Luiz Alberto Gomes de Souza, Haroldo Borges Rodrigues Lima, Cosme Alves, Duarte do Lago Brasil Pacheco Pereira, Antonio Lins, Severo Albuquerque Sales, Péricles dos Santos, Maria Angélica Duro e Manuel Joaquim Barros ("História da AP", Aldo da Silva Arantes e Haroldo Borges Rodrigues Lima, editora Alfa-Omega, 1984). Utilizando a União Nacional de Estudantes e, mais propriamente, a chamada "UNE volante", foram organizados vários núcleos da Ação Popular pelo Brasil, tendo como base militantes da JUC. Nessa etapa, a AP adotou como filosofia as teses do padre Henrique de Lima Vaz que foram aprovadas em um Congresso da Organização, realizado em 1963 em Salvador-BA. Essas teses receberam a denominação de "Documento Base".

${ }^{47}$ Para mais informações ver: BRANDÃO, C.R.(1981) “O que é o Método Paulo Freire”. Brasiliense. São Paulo. 
um abaixo assinado que gestou o movimento que deu origem à passeatas por todo Brasil exigindo uma Escola Pública de Qualidade.

Chopin Tavares de Miranda (Secretário da Educação), Leonel Brizola (Político e fundador do PTB), Florestan Fernandes (Intelectual), Rubens Paiva (Deputado Federal), Almino Afonso (Ministro do Trabalho e Desenvolvimento de João Goulart), Márcio Moreira Alves(Deputado, autor do discurso que supostamente levou à criação do AI5), Antonio Cândido (intelectual e crítico literário), e outros, passaram a manter estreita ligação com um grupo de professores da Faculdade, dando palestras e ajudando a promover na região um grande movimento social.

Educar parece ter sido, sempre um dos lemas que orientou os professores e mentores de tal movimento, mas como tudo isso repercutia naquela cidade do interior do Estado de São Paulo? O que representava para as oligarquias da chamada “Boca do Sertão" todas essas mudanças de padrões, comportamento e valores?

Essas perguntas podem ser respondidas se observarmos os muitos problemas institucionais e a nível municipal enfrentados por um grupo de professores. Era clara a hostilidade, da área municipal aos círculos chegados da capital do Estado. Pais de filhas bem nascidas acreditavam ser uma aberração professores permitirem que as mesmas fossem, após as aulas, tomar cerveja com eles. Havia até os que diziam temer uma USP Caipira. O que não ocorreu, pois a Faculdade se firmou como uma escola de ensino e pesquisa renovadores, sendo uma das primeiras que teve representação paritária entre alunos e professores, isto é nos cursos de Pedagogia, Letras e Filosofia, pois os professores do curso de História Natural não aceitavam isso. Deu-se aí a grande ruptura dentro da faculdade que teria um papel fundamental em 1964. Tal situação foi tão intensa que os professores de ambos os grupos deram inicio à discussões públicas pelos jornais da cidade. ${ }^{48}$

Outro problema sério da Faculdade dizia respeito ao seu diretor o Dr. Rafael Grisi, acusado pelos professores de abandono da Faculdade, desvio de verbas e má

\footnotetext{
${ }^{48}$ Ver artigos em Anexo 3
} 
conduta. Foram várias as correspondências dos professores contra o Dr. Grisi para os órgãos e pessoas encarregados da educação naquele momento, deu-se assim o afastamento do Dr. Grisi da direção da Faculdade acirrando ainda mais os ânimos já exaltados de professores com visões e aspirações diferenciadas.

É possível que esses problemas tenham influenciado diretamente na intervenção na Faculdade, uma vez que o próprio professor Daud Jorge Simão se encarregou de denunciar vários colegas e alunos da FAFI.

A Faculdade Isolada de São José do Rio Preto foi a primeira faculdade do Brasil a sofrer intervenção em 01 de abril de 1964 as 9h30. Após esse Golpe, foi implantada uma universidade manu militari, visando impedir que a universidade pudesse a vir desempenhar qualquer atividade contestadora, como ocorrera no passado recente. Em suma, a universidade foi esterilizada politicamente, diga-se de passagem, com a franca e aberta colaboração de professores e estudantes adeptos da contra- revolução e do regime ditatorial. (FERNANDES .1975)

Embora exista uma ampla historiografia sobre o Golpe de 64, possivelmente a validade deste trabalho e do Corpus Documental está no preenchimento da lacuna historiográfica sobre os acontecimentos envolvendo a relação FAFI - Ditadura Militar no interior de São Paulo. 


\section{PARTE V}

Você que crê firmemente

Que o Brasil vai muito bem

Que crê bandeirantemente

Que São Paulo puxa o trem

Que crê philadelphamente

Que Rio Preto vive bem

Dê-me a mão, venha por aqui

Longe desse você

Tão bem.

(Desova Poética/ Orestes Nigro) 


\section{PROFESSOR ORESTES NIGRO.}

O Professor Orestes me recebeu em seu apartamento no centro de São Paulo, pela primeira vez numa sexta-feira a tarde. Fui muito bem recebida, pois já o conhecia de longa data, em seguida nos encaminhamos para o seu quarto-escritório, onde ele mantém seu computador, uma estante imensa repleta de filmes e uma cadeira de ferro branca. Ele apresentou ter uma facilidade espantosa para datas e meses e continua sendo uma pessoa muito divertida, daquelas que a gente não se cansa de ouvir. Voltei a sua casa mais duas vezes e acredito ainda ficou muito a ser contado...

Hoje fico pensando e cada vez mais me convenço que nós éramos um pessoal aberto, mente aberta, e essa era nossa característica principal.

Meu nome é Orestes Nigro, nasci em julho na cidade de Itápolis. Tive uma infância muito modesta, meu pai levantava de madrugada, passava os dias batendo martelo na bigorna e quando não conseguia terminar o serviço continuava trabalhando noite adentro à luz de um lampião. Minha mãe era costureira, banqueteira, dava pensão para 8 estudantes e se houvesse algum trabalho mais que ela pudesse fazer para ganhar algum dinheiro ela fazia. Acho necessário contar essas coisas para você entender o desenrolar da minha vida acadêmica e como minha infância deixou marcas e me fez transformar no profissional que fui e sou. Certo dia, era criança, sai com um tio para passear no centro da minha cidade. Ao passarmos pelo Boulevard Itápolis que é um lugar chiquérrimo onde só havia produtos importados, percebi a presença de vários homens muito bem arrumados, de terno e colete, sentados na mesinha de um bar fumando charutos. Fiquei encantado com tanta elegância e perguntei ao meu tio quem era aquelas pessoas, afinal eu sempre as via ali sentadas, conversando... fumando... sempre limpas, bem arrumadas... será 
que eram da polícia? Meu tio riu muito e disse que não, aqueles homens eram capitalistas. Fiquei mais confuso ainda... o que era ser capitalista??? Meu tio, com toda paciência que lhe era peculiar disse que eram pessoas que possuíam muito dinheiro, tanto, que podiam emprestar a juros para outras pessoas desde que elas assinassem letras promissórias. Letras promissórias??? Foi a primeira vez que ouvi falar nisso na minha vida. Fiquei absolutamente admirado pensando que se aqueles homens não trabalhavam e tinham aquele vidão... não tive dúvidas, disse a meu tio que iria pedir para que meu pai parasse de trabalhar, colocasse um terno e viesse para o Boulevard também. Quem sabe nossa vida melhoraria? Meu tio me olhou com um meio sorriso e disse: Orestinho, ele me chamava de Orestinho porque meu avô era Orestes, aprende uma coisa, quem trabalha não tem tempo de ganhar dinheiro.

Resolvi que estudaria muito para ter uma vida melhor e lutaria para proporcionar uma vida melhor às outras pessoas também. Consegui entrar na USP Maria Antonia e foi ali que conclui o ensino superior. Logo ao terminar fui convidado para lecionar na recém inaugurada Faculdade Municipal de São José do Rio Preto. Era longe de São Paulo, mas eu não podia perder aquela oportunidade. Logo que cheguei à cidade encontrei os colegas que haviam sido contratados, a maioria deles também formara-se na USP. Em nossa primeira reunião de congregação, o Rodolfo Azzi, que era professor de Psicologia, e era uma pessoa genial perguntou que tipo de faculdade nós queríamos. Afinal, éramos considerados malditos na USP porque criticávamos a estrutura dela e várias outras coisas com as quais não concordávamos. Tínhamos que definir naquele momento que tipo de faculdade iriamos construir: uma USP rural ou uma faculdade nova, como a USP que sonhávamos? O Wilson Cantoni, que era inteligentíssimo, disse que construiríamos uma faculdade nova, mas que não nos iludíssemos, pois iríamos assustar os fazendeiros e empresários locais que, com certeza, se sentiriam ameaçados com nossas propostas. Nós pretendíamos transmitir aos nossos alunos uma mentalidade que iria refletir na casa deles, mostraríamos a injustiça social, lutaríamos por 
melhores salários, por um país mais justo e sabíamos que teríamos que colher o fruto da discórdia que iria haver.

A Faculdade foi fundada em 1957 e desde o inicio enfrentamos resistências. Tanto pelo fato de termos tomado o lugar dos professores locais que tinham certeza de lecionar nela como pelo fato de ter uma posição revolucionária, inovadora, que rompia com os padrões existentes. Começamos modificando a relação aluno/professor. Na USP chamávamos o professor de Vossa Excelência e em Rio Preto era você. O Norman era Norman, o Orestes era Orestes e assim por diante. Na USP os alunos tinham que vestir terno e gravata, e as moças vestido social... lá em Rio Preto nossos alunos iam para a aula de chinelo de dedo, tiravam o chinelo na classe e andavam descalços. Evidentemente acharam que isso ia contra a ordem e o progresso, o que eu discordo, poderia ir contra a ordem, agora nós éramos o progresso e isso chocou as pessoas de uma cidade conservadora do interior paulista.

Rapidamente percebeu-se que seria difícil para o município manter a faculdade. Foi eleito, então para a prefeitura um homem muito inteligente chamado Alberto Andaló. Logo no inicio ele nos chamou e disse que se não fizéssemos alguma coisa a faculdade estava fadada a virar uma escola mista do Bairro da Boa Vista, a região onde estava situada. Resolvemos lutar junto ao governo do Estado para que a faculdade fosse estadualizada. $O$ prefeito encabeçou um movimento regional e nós fomos ajudá-lo, afinal éramos os principais interessados. Visitamos todos os prefeitos da região... todos... até a Barranca do Rio Paraná, a Barranca do Rio Grande, a Alta Araraquarense e solicitamos que eles enviassem, para a prefeitura de Rio Preto, telegramas solicitando a estadualização,juntamos todos aqueles telegramas e viemos direto para o palácio do governo, que ficava no centro de São Paulo, dava para ver aqui da minha janela. O que vou contar agora foi uma reunião histórica. Encontramo-nos com o Janio Quadros e o Alberto Andaló fez o pedido. Foi cômico! O Jânio com aquele jeito peculiar de falar disse: Alllbbbeeerrrtoooo Annndaaalloóóó, eu não posso te dar issooo.... o que você está me pedindo é um absurdoooo..... O Alberto ficou muito bravo. Ele era o principal cabo eleitoral do Jânio naquela região, um homem de muito prestigio, mas era também um cavalo de 
mal-educado... virou as costas e disse ao Jânio: Então você vai pra puta que o pariu, nos chamou e fomos saindo... quando estávamos quase na porta o Jânio disse nos daria a Faculdade, mas que fazia questão que não houvesse nenhum professorzinho local porque não queria que ninguém fizesse política com ela. Ele fazia questão que os professores fossem todos formados pela USP. Conseguimos a estadualização da faculdade que passou a se chamar Faculdade Isolada de São José do Rio Preto e aí começaram nossos problemas.

Interesses locais haviam sido contrariados com a exigência do governador. Nesse momento caiu por terra o castelo do Daud Jorge Simão, por exemplo, que havia pensado o projeto da faculdade em beneficio próprio e que sentiu-se tremendamente injustiçado, pois ele não havia se formado na USP, além disso era um sujeito muito chato. Corria em Rio Preto uma piada que a primeira mulher dele que havia sido atropelada ao atravessar a linha do trem, na verdade se suicidara, pois nem ela conseguia agüentar mais o marido que tinha. Ele queria ser tudo, dizia que tinha diploma de química, de odontologia, de direito e nós nos divertíamos muito dizendo que ele também deveria ter diploma de culinária da Walita. Além de tudo ele tinha mania de fazer trocadilho, tinha uma voz muito chata, era muito insistente e nós percebemos que estava tentando influenciar nosso trabalho. Nós o isolamos e ele percebeu isso. Juntou-se então a outros professores da cidade, que eram considerados a elite intelectual e resolveram nos boicotar. Houve outro problema sério: o diretor, Dr. Rafael Grisi, praticava várias irregularidades, usava transporte público para fins particulares, não ficava na faculdade, suspeita-se que desviava verbas, e isso nos levou a escrever várias denúncias para o secretário da educação, e também nos valeu uma demissão, ele não renovou nossos contratos, porém por pressão dos alunos teve que nos readmitir. Isso foi por volta de 1963.

Pelos jornais nos criticavam, não aceitavam convites para nada, criticavam nossas aulas e até influenciaram o bispo auxiliar de Rio Preto que começou a fazer campanha contra nós. Quando esse bispo soube que eu era católico mandou me chamar ao palácio episcopal para questionar as leituras que eu havia indicado aos alunos, imagine, ele estava uma fera, pois entre os textos estava Voltaire. Naquela 
época a Igreja ainda tinha o Index de Livros Proibidos e dentre eles constavam os textos de muitos filósofos importantes. Agora, como deixar de estudar esses autores tão importantes com meus alunos? Nem pensar! Enfim, tudo isso criou uma mágoa local que no futuro iria nos prejudicar muito, pois esses professores foram os primeiros a depor contra nós quando fomos presos por ocasião do Golpe de 64 .

Logo no inicio criamos um movimento que se transformou num movimento nacional em defesa da escola pública no Brasil e vou explicar como ele surgiu.

Havia um projeto no Congresso Nacional, cujo porta-voz era o gorila do Carlos Lacerda que mereceu uma paródia minha ${ }^{49}$ e era governador da Guanabara. O Lacerda havia assinado um acordo com os americanos, não gosto nem de falar nesse nome... americanos... tenho ojeriza a tudo que vem de lá, bem era um acordo chamado MEC USAID... Meu Deus... isso acabou, liquidou com o ensino público...imagine que começaram a distribuir verbas públicas para escolas particulares, introduziram uma série de métodos de ensino americanos inadequados ao ensino brasileiro... O Wilson Cantoni e o Norman Potter encabeçaram a elaboração de um manifesto que foi assinado por muita gente importante, inclusive do Rio de Janeiro que era a capital... até os trogloditas da História Natural como o Celso Abade Mourão, assinaram... estávamos só nos defendendo... éramos escola pública... não podíamos admitir aquilo. Acontece que os donos das porcarias das faculdades particulares de Rio Preto, principalmente o de uma arapuca que ficava nas esquinas das ruas Rubião Junior com a General Glicério, o Alin Atike, tinham gente na Câmara Municipal e começaram a falar que aquele manifesto era comunista. Imediatamente os "colegas" da História Natural, entre eles o Celso Abade Mourão e o Luiz Dino Vizzoto resolveram ir até a Câmara e retirar a assinatura do documento. Foi um dos primeiros passos para a cisão na Faculdade.

Imagine dizer que éramos comunistas. Eu não era comunista, sou católico. Tínhamos pensamentos de esquerda que nos levavam a querer mudar, a querer

49 "Lá na direita, na direita tem um gorila, que governa a Guanabara, que governa a Guanabara, seu nome dá uma boa rima, seu nome dá uma boa rima. Adivinha, adivinha tá na cara. Adivinha, adivinha tá na cara". 
melhorar, fazer uma distribuição de renda mais justa, dar oportunidade a todos para estudar... isso não é comunismo gente!

Por volta de 1960 a Faculdade mudou de lugar. Fomos para dois prédios combinados na Rua General Glicério e nosso espaço ficou muito maior. A cantina era grande, tinha mesinhas, cadeiras, tinha um auditório, que embora fosse rústico, era muito espaçoso, onde nós podíamos afastar as cadeiras e jogar ping-pong e isso possibilitou o encontro de muita gente num mesmo local. Foi aí que surgiram os primeiros movimentos para a criação do GRUTA, não só do GRUTA, mas de outras coisas também. A Faculdade funcionava a todo vapor, pela manhã, a tarde e a noite... com os mesmos alunos. Os cursos regulares eram ministrados no período da manhã, a tarde fazíamos grupos de trabalho e a noite seminários, simpósios, conferências. Os alunos tinham vida integral na Faculdade e até os que trabalhavam davam um jeitinho de passar por lá.

O GRUTA era um grupo de teatro amador que além de fazer arte promovia vários eventos também. Eu o criei como opção de conhecimento para os alunos e também para me divertir, foi muito espontâneo, nada muito pensado. Levamos para se apresentar na Faculdade a Inezita Barroso que sabe tudo de folclore, a Maria Lívia São Marcos que era a maior violinista do Brasil; levamos o Gianfrancesco Guarnieri para fazer uma conferência sobre teatro, ele acabou se tornando um grande amigo , tenho até algumas fotos dele jovenzinho, o Juca de Oliveira veio com ele e também ficou meu amigo. Tempos depois resolvemos fazer a Semana de Estudos Brasileiros, no mês de agosto e convidei a companhia de teatro do Fernando Torres, marido da Fernanda Montenegro para se apresentar em Rio Preto. Ele aceitou e trouxe o Francisco Cuoco, a Zilka Zalaberry, o Labanca, o Sérgio Brito e a própria Fernanda, foi um sucesso. Eu tinha uma capacidade muito grande de organizar eventos culturais de peso e eles foram acontecendo freqüentemente, até que o Cantoni um dia me chamou e me perguntou se eu tinha noção do alcance desse movimento todo, dessa organização do GRUTA, perguntou se eu percebia o que estávamos fazendo . Respondi a ele que não tinha intenção de fazer movimento nenhum, que tudo era uma grande diversão, porque eu vivia aquilo artisticamente. Ele disse que 
organizássemos isso, que déssemos estrutura, fizéssemos um estatuto, porque iríamos crescer muito. Se não houvesse havido a Revolução de 64 eu não sei o que teria virado o GRUTA. Acho que um grande movimento.

O grupo empolgou muito e as pessoas foram cada vez mais participando, o Edson Guiducci, o Grigor Vartanian, a Eudete Focchi que se tranformou no meu braço direito, ela tinha uma cabeça muito boa, a Isabel... convidamos o Rubens Paiva, que era um deputado empresário que tinha uma visão muito aberta para fazer uma palestra lá, veio o Antônio Candido que era um santo. O Antônio Candido era uma das pessoas mais prestigiadas da USP, não por decisões políticas, mas pela sua capacidade como mestre da literatura brasileira, veio o Almino Afonso...eles vinham falar sobre coisas que interessavam a todo mundo, inclusive a operários e camponeses, embora nós não tivéssemos nada a ver com os movimentos deles. $\mathrm{O}$ único contato que tivemos com camponeses foi quando o fazendeiro Olavo Fleury permitiu que alfabetizássemos seus empregados pelo método Paulo Freire. O Olavo permitiu e até isso nos prejudicou. Quando fomos presos isso depôs contra nós, mas ninguém chamou o Olavo para depor, afinal ele era parte da elite... freqüentava o Automóvel Clube...

Recordo-me bem de um poema do Vinicius de Moraes que transformamos num jogral e que apresentamos, chamava-se Senhores Barões da Terra... sabe que isso me lembra, já depois da Revolução, quando eu estava morando em Monte Aprazível, recebi uma carta comunicando que havia recebido um premio de poesia na categoria de poesia social. Era um prêmio para a América Latina. Eu e o Vinicius recebemos, ele com Senhores Barões da Terra e eu com um poema cujo nome não lembro, mas que colocava Jesus como líder revolucionário e era em forma de cruz. Sabe, chegamos a publicar um livro de poesias de integrantes do GRUTA, a Primeira Desova Poética.

Aí veio a Revolução! Fui acusado de ser comunista. Nunca li Marx e nem tenho intenção de ler. Nunca fui teórico. Para mim política é um negócio que corre na pele. Quando fui preso e o delegado perguntou se eu era comunista eu disse a ele 
que não sabia bem o que era. Falei que politicamente não era, pois não pertencia ao partido e nunca havia lido nada sobre isso, nem que eu quisesse ser comunista poderia afirmar isso, para ser comunista tem que se conhecer a teoria, os manifestos e eu não conhecia. Disse a ele : o que sou doutor é um inconformista e dessa maneira sou capaz de fazer coisas piores que os comunistas. Se souber de alguém que está explorando, escravizando as pessoas o senhor me dá uma arma que vou lá e mato. $\mathrm{O}$ senhor quer colocar aí que sou perigoso, coloque, agora comunista não sou.

Sabe, não acredito no comunismo. Quando era aluno da Letras na USP, havia um rapaz todo descabelado, todo sujo, que era considerado um dos comunistas de lá. Um dia estávamos eu e o Professor João Dias da Silveira conversando em frente à universidade quando esse camarada passou e o professor Silveira disse que se déssemos um bom emprego com o qual o rapaz pudesse comprar seu terno, ele tinha certeza que o comunismo dele acabava como que por encanto. E eu vi isso acontecer o tempo todo durante a minha vida.

Em Monte Aprazível havia um juiz de Direito novinho, cheio de idealismo, de esquerda, o Dr. Wanderley Borges... de Monte ele foi transferido para o ABC, onde participou do Movimento Operário, até que foi transferido para São Paulo. A última vez que o vi foi em uma festa na casa dele, na Avenida Angélica, num apartamento maravilhoso, com convidados do mais fino trato, não gente como a gente, com uísque importado... logo pensei: ele se aburguesou... continuei amigo dele, não faço distinção e ele até já morreu. Comunista.... tá bom!

Durante todo o processo diziam que o Cantoni era comunista, que comunista que nada, ele era fabuloso, mas o sistema não tinha alcance para entender isso. A própria policia de Rio Preto não sabia o que estava fazendo. O Heimer deu um baile no delegado que perguntou a ele se ele se considerava subversivo. Ele pediu ao delegado que definisse subversão. O delegado não soube fazê-lo e o Heimer disse que ele estava falando besteira, isso lhe valeu muita pancada. O Heimer foi o único que apanhou lá, muito. Ele enfrentava a policia e daqui acabou indo para o Chile, depois com o Pinochet... deve ter voltado para a Alemanha. 
Nós fomos presos para desmontar esse nosso esquema, lógico!

Depois que saí da cadeia quase fui preso novamente porque resolvi ir até a Faculdade buscar minhas coisas. Assim que cheguei lá foi uma choradeira, alunos me abraçando... e aí aconteceu uma coisa muito triste. Havia um funcionário que eu levei para a faculdade, pois ele era motorista de táxi e estava passando por dificuldades... arrumei emprego para todos os filhos dele, pois bem, assim que me viu na faculdade chamou uma verdadeira "Rota", que me levou para a sala do novo diretor, que era um Juíz de Direito chamado José de Castro Duarte, conhecido como "O Carrasco da Ilha Grande". Na sala ficaram o Aristides, os policiais e o diretor que começou a gritar comigo dizendo que eu havia sido demitido para desinfetar a faculdade, que não aparecesse mais lá... eu disse que não havia recebido nenhuma restrição de movimentos, que apenas havia ido buscar minhas coisas... lá havia muitas coisas, livros, jornais franceses que eu assinava, toda minha vida profissional. Ele respondeu que no sábado próximo enviaria tudo para minha casa, que eu não pisasse mais lá, se isto acontecesse seria preso e enviado para o Deops em São Paulo e o Aristides assistindo tudo, não moveu um dedo...

Hoje fico pensando e cada vez mais me convenço que nós éramos um pessoal aberto, mente aberta, e essa era nossa característica principal. Se um centro espírita nos convidasse para fazermos uma palestra nós íamos, se o sindicato convidava o Cantoni para uma conferência, ele ia. Ele tinha amizade com o Celso Furtado, com o Almino Afonso, o Darcy Ribeiro era nossa amigo, o próprio Fernando Henrique, que era de esquerda nessa época, depois você viu o que virou, era nosso amigo e a Revolução foi feita contra essas pessoas, claro que se tínhamos amizade com elas....

Penso que as mais prováveis causas de nós termos sido as primeiras vitimas foram que Rio Preto era na época um baluarte da direita reacionária brasileira, tanto assim que ganhara o apelido de Dallas paulista, lembre-se do assassinato de Kennedy. Era também uma cidade geograficamente estratégica para mais fácil acesso às fronteiras de Minas Gerais, Goiás e Mato Grosso, como foram os militares que preparam o Golpe de 64.... para completar Rio Preto tinha na época as autoridades 
mais reacionárias do Brasil, prefeito Loft Bassit, juiz da comarca José de Castro Duarte, e um delegado regional de polícia ambicioso demais em termos de carreira, Tácito Pinheiro Machado, que deitou e rolou durante a primeira fase repressora e como prêmio tornou-se Delegado Geral de Policia, segundo cargo mais importante na hierarquia da Secretaria de Segurança Pública. Enquanto nas outras cidades da região as autoridades discutiam para depois prender, Tácito primeiro prendia, para depois discutir. Por isto logo no dia $1^{\circ}$ de abril de 64 , a cadeia de Rio Preto estava cheia de presos políticos. 


\section{JUCA DE OLIVEIRA}

Entrei em contato com o Juca de Oliveira via e-mail conseguido por Ricardo Santhiago ${ }^{50}$. Ele foi muito solicito e em seguida me recebeu no seu apartamento localizado nos Jardins. Foi muito simpático, ficou emocionado enquanto narrava o que havia acontecido em Rio Preto e ao final da entrevista me ofereceu uma cachacinha...

Acredito que eles já tivessem o germe de 68, do que ocorreu na França, e isso já estava engendrado dentro da escola. Era uma coisa viva, atuante, muito atuante.

Meu nome é Juca de Oliveira sou ator e escritor. Por volta dos anos 60, eu fazia parte de um grupo de teatro chamado Arena que, de vez em quando, fazia excursões pelo Brasil para mostrar as peças encenadas em São Paulo. Íamos para o nordeste, para o sul do país e também para o interior de São Paulo, inclusive São José do Rio Preto, cidade que passamos a visitar sempre que possível. Nosso primeiro contato lá foi um grupo de teatro que havia na Faculdade, a Fafi. Em toda cidade que o Arena visitava, estabelecíamos um contato muito próximo com os amadores de teatro local e o meio universitário. Interagíamos com os jovens, s grupos de teatro que se formavam sozinhos, grupos de teatro amador e, sobretudo, teatro de estudantes. Em Rio Preto encontramos os participantes do GRUTA, o grupo de teatro amador integrado por jovens extremamente interessados em problemas sociais e, como no Arena fazíamos um teatro social e político, éramos militantes políticos, alguns comunistas, outros trotskistas, fomos bem aceitos pelo grupo. $O$ primeiro contato na cidade foi com o Orestes Nigro, professor de francês, fundador e líder do Gruta.

\footnotetext{
50 Produtor cultural e mestrando da USP.
} 
Orestes, homem preocupado com questões sociais, organizara o seu grupo de teatro dentro da Faculdade, a partir da música, violão, canto em permanentes saraus alegres e muito concorridos pelos estudantes. Claro que as questões sociais estavam sempre presentes nessas reuniões. O contato com esse grupo e o Teatro de Arena se tornou muito estreito. Lá encenamos algumas de nossas peças. Eu mesmo voltei várias vezes a Rio Preto, onde apresentei dois recitais de poesia. Também fazíamos palestras sobre Teatro, Guarnieri falava sobre dramaturgia, Boal sobre direção.

Na faculdade havia uma professora, cujo nome não me lembro, assistente do Orestes e que também ajudava a dirigir o grupo de teatro, o Gruta.

O que a gente constatava é que nessa faculdade a relação entre alunos e professores era muito mais avançada e menos formal do que na maioria das faculdades da época. Havia camaradagem intimidade e grande respeito. Imagine no início dos anos 1960 professores de uma faculdade tocando violão, discutindo política, fazendo teatro social e político dentro de uma instituição pública no interior de São Paulo... Era impensável!

Claro que isso deve ter incomodado, e muito, setores mais conservadores da cidade. Imagino que essa convivência tão democrática deva ter sido o fator principal da intervenção militar que ocorreu na cidade em 64. O que não é de se espantar, pois em todos os lugares onde havia movimentos culturais semelhantes aos de Rio Preto deu-se reação semelhante por parte dos militares. Nós aqui em São Paulo, em 64, tivemos o nosso teatro fechado e fomos exilados. Eu mesmo estive na Bolívia com o Guarnieiri.

O Orestes era uma pessoa muito avançada para sua época, era um professor com tendências socializantes, agindo abertamente dentro da faculdade, aplicando um tipo de ensino diferente, democrático, sempre estimulando os alunos a se inteirarem dos problemas sociais e políticos da cidade, do estado e do país. O professor Orestes não era militante político, não era comunista. Apenas levou a idéia de democracia para dentro da escola, o que fascinou os alunos, que antes eram orientados segundo princípios tradicionais e pouco estimulantes. Era uma loucura! 
Samba... discussões políticas, teatro político... Violão, saraus! Almoçávamos com os alunos, conversávamos sobre teatro, técnicas de interpretação, Guarnieri falava sobre dramaturgia, sobre autores, Stanislavsky, "A Mandrágora", Maquiavel e eles adoravam.

Nosso contato ficou muito estreito e o Orestes acabou se tornando um grande amigo, em quem confiávamos para falar ou discutir sobre qualquer tema, com ele ou com o grupo de professores que ele liderava na Faculdade. Claro que também havia professores que não concordavam com os métodos do professor Orestes, acredito que tivessem ciúme por não desfrutarem do mesmo afeto dos alunos. Provavelmente foram esses colegas do Orestes os primeiros a denunciar a democracia interna da Escola aos movimentos reacionários da cidade. O que não era difícil. O Deops estava em todo lugar, era só dizer que havia comunistas infiltrados ali e... pronto!

Quando houve a Revolução foi um Deus nos acuda! É lógico que o governo militar, isso me parece absurdamente óbvio, queria acabar com as idéias sobre educação do grupo do Orestes. Afinal durante o regime militar a orientação do Ministério da Educação era no sentido de uma escola menos avançada, que não tivesse professores de esquerda ou estudantes que participassem de movimentos sociais, sobretudo ligados a sindicatos... E aí Rio Preto sofreu a intervenção. Afinal lá havia tudo o que os militares não queriam.

O fato de o diretor, que foi nomeado para intervir na faculdade, ser chamado de "carrasco da Ilha Grande" é bastante óbvio também.

Se você tem uma cidade como Rio Preto, no interior, conservadora, agrícola, ligada à produção de café, à criação de gado, menos industrializada que Ribeirão Preto, e nela surge um movimento cultural de esquerda, muito nítido e atuante, é claro que para os conservadores poderia, quem sabe, haver alguma ligação desse movimento com as Ligas Camponesas, com o Araguaia! Para o delírio deles qualquer coisa servia... Por isso eles escalaram uma pessoa muito ligada aos militares e a colocaram lá, pois acreditavam piamente que o movimento fosse politicamente organizado... Uma bobagem. 
Claro que não havia nada de "subversivo ou de guerrilha" na faculdade. Foi uma esquizofrenia, uma psicose, uma loucura o que aconteceu. Não existia nenhum movimento organizado na Faculdade para "subverter a sociedade" Era apenas um movimento cultural muito parecido com o nosso, nós também não tínhamos a intenção de tomar o poder, o Arena só fazia teatro social, abordava problemas sociais, denunciava, o que, na verdade, continuamos fazendo até agora. Eu mesmo vou estrear uma peça que é um libelo, só que agora é contra a corrupção, a falta de ética, sobre as coisas que vêm acontecendo em nosso país e que estão enfraquecendo as instituições e ameaçando a democracia.

Houve intervenção em outras faculdades também. Na USP tomaram o campus, expulsaram os professores, o Hildebrando foi para a França, ficou no Instituto Pasteur, acabou de voltar ao Brasil, o Paulo Mendes Rocha, o Artigas, enfim, amigos nossos foram afastados, aposentados, expulsos ou exilados. Acontecer isso na USP era até esperado, mas em Rio Preto... Foi espantoso!

As idéias novas defendidas pelo Orestes no meio da caipirada... Foi complicado. Veja, eu também sou caipira, moro numa fazenda em Itapira há 30 anos, imagine se chega lá um grupo de esquerda e começa a pregar... aliás houve um problema sério na cidade, em uma outra época, mas que ilustra o pensamento conservador: o assassinato de Joaquim Firmino, delegado de polícia, mas que se condoia da sorte dos escravos torturados pelos fazendeiros. Ele foi um líder antiescravagista que se tornou mártir. Foi trucidado por 250 fazendeiros porque estava acolhendo escravos que já eram livres, já havia ocorrido a abolição. Porém os fazendeiros queriam aproveitá-los para fazer a última colheita de café... Ficaram furiosos com Firmino, invadiram sua casa à noite e o mataram. Era o ano de 1888. Foi um assunto que galvanizou o país todo. O advogado dos assassinos era o Assis Brasil. Eles escreveram uma página na história que manchou para sempre a cidade. Ela se tornou maldita, estigmatizada e, para resolver isso, trocaram o nome de Penha do Rio do Peixe, que eu acho lindo, para Itapira. Isso dá para se ter uma idéia do perigo que é defender uma idéia nova no interior, onde as pessoas são conservadoras. 
Perto de Rio Preto tinha um líder camponês chamado Jofre Correa Neto que costumava freqüentar algumas palestras. Isso, porém, era um problema dele. As palestras eram abertas e, se o Prestes resolvesse ir, isso não significaria que era uma fala comunista. E nem por isso o pessoal de Rio Preto tinha algo a ver com ele. Ele ia às palestras, e daí? Achar que todo mundo é comunista é um absurdo, é o papel da repressão. O papel dos conservadores é sempre esse.

Fico feliz por o Orestes estar vivo, tenho certeza que a preocupação dele sempre foi com o social, com um mundo menos injusto e a conscientização da juventude para tornar este mundo num lugar melhor. O Gruta para ele era uma grande diversão, pois era quem mais se divertia. Ele cantava, fazia corais, jograis, participava de tudo e, quando íamos para lá, era uma festa. Olhávamos para ele e o víamos iluminado com aquela estudantada. Ele batia papo, estimulava todo mundo... A questão dele era social... Queria fazer com que a situação ficasse legal, que todo mundo tivesse tudo, que todos percebessem o caminho.

Acredito que eles já tivessem o germe de 68, do que ocorreu na França, e isso já estava engendrado dentro da escola. Era uma coisa viva, atuante, muito atuante. Eles moravam dentro daquela faculdade, de manhã até a noite existia movimento naquele lugar. O Guarnieri, então, os estimulou para que escrevessem suas próprias peças e músicas, pois ele era muito ligado à criação, um escritor famoso em quase todo o mundo.

De repente eles estavam compondo, o Orestes tocando violão e o pessoal cantando, compondo peças próprias, fazendo poesias. Essa era uma preocupação que nós do Arena tínhamos, fazer com que os amadores não ficassem a reboque do que acontecia no eixo Rio-São Paulo. Queríamos que eles produzissem sua própria cultura, que procurassem seus próprios problemas, que eles fizessem o que fosse possível dentro da realidade deles ao invés de importar tudo . Música e teatro e cinema, que eles procurassem fazer tudo o que era possível, viável e eles estariam fazendo uma coisa que, além de ser original, seria única, porque seria a realidade deles, não? Isso também foi feito lá, o Guarnieiri estimulou muito nesse sentido. 
Depois de 64, mesmo com o Orestes afastado da Faculdade e tendo que se mudar para uma cidade próxima de Rio Preto, Monte Aprazível, nosso contato continuou. Estive em Monte Aprazível, fiz espetáculos em um circo, dei palestras, debati com estudantes... Isso significa que, mesmo tendo problemas com os militares, o Orestes continuou lutando por suas idéias.

Todos nós deveríamos nos orientar pelo seu exemplo. 


\section{FRANZ WILHEIM HEIMER}

Localizei o professor Heimer através do Centro de Estudos Africanos que fica no ISCTE (Universidade Pública especializada em Ciências Sociais e Empresariais, Sociologia do desenvolvimento e Sociologia africana), via internet. Falamo-nos a princípio por e-mail e depois pelo skype, portanto esta entrevista, embora tenha sido feita oralmente não obedeceu aos procedimentos padrões da História Oral, uma vez que não fiquei frente a frente com meu colaborador, porém julgo que ela é fundamental para o meu trabalho, por esse motivo resolvi utilizá-la.

\section{Fui transferido para o DOPS, provavelmente, porque havia uma idéia fantasmagórica de eu ser um agente internacional comunista.}

Meu nome é Franz Wilheim Heimer e vou tentar me concentrar especialmente para ver com o que posso contribuir para seu trabalho. Creio que nesse sentido, minha contribuição baseia-se numa permanência relativamente curta em São José do Rio Preto, de 1961 a 1964. Após o Golpe Militar, saindo do DOPS, para onde fui enviado de Rio Preto, mudei-me com minha família para Belo Horizonte, para assumir lá as funções de diretor da filial do Goethe-Institut (Instituto de Cultura Alemã). Em razão da abertura de processo judicial em São José do Rio Preto, tive que retornar para lá uma vez onde fui ouvido por um juiz (visivelmente descrente quanto às acusações constantes nos autos.

A Embaixada da RF Alemanha impôs-me já em 1965 a saída do Brasil, que seria ilegal face à lei brasileira, devido ao processo pendente, mas a mesma foi negociada pela própria Embaixada com não sei qual entidade do complexo militar então reinante.

$\mathrm{Na}$ Alemanha, deixei de imediato o domínio das letras, onde havia me formado. Passei a ser pesquisador de um Instituto especializado nos estudos dos "países em desenvolvimento", com trabalhos inicialmente concentrados na América Latina, que me levaram uma vez a uma breve estadia no Brasil, seguidos por uma 
transição para o domínio dos estudos africanos. Fiz o doutoramento em Ciência Política e Sociologia e fixei-me em Lisboa onde ensinei no ISCTE (Universidade Pública especializada me Ciências Sociais e empresariais), Sociologia do desenvolvimento e Sociologia africana, e estive na origem de um, hoje importante, centro de estudos africanos.

Voltei algumas vezes ao Brasil, mas sempre para visitas familiares, e ocasionalmente aproveitei para breves contatos com correligionários, por exemplo, o falecido "Betinho".

Sou professor catedrático aposentado desde 2000, mas de fato continuo ativo como pesquisador sênior do CEA (Centro de Estudos Africanos).

Chegando a São José do Rio Preto em meados de 1961, fui de imediato integrado a um grupo de professores da FAFI (Faculdade Isolada de Filosofia, Ciências e Letras) que eram de forma imprecisa "da esquerda"(não comunista!) e onde as figuras de maior destaque intelectual eram, pelo que me ficou na memória o Professor Wilson Cantoni,(sociólogo), Flávio di Giorgio (letras latinas) e o Noman Potter (letras inglesas).

Minha própria "socialização ideológica" havia sido marcada por uma militância, na Alemanha e na central internacional com sede em Paris, da JEC/JUC (Juventude Estudantil e Universitária Católica). Como minha primeira mulher, Maria de Lourdes Oliveira Santos, provinha da JUC brasileira, concretamente a baiana, tivemos contatos imediatos com figuras proeminentes desta em São Paulo, no Rio de Janeiro e em Salvador.

Em 1962 tomei a iniciativa de viajar à Recife para encontrar o Paulo Freire e seu grupo. Meu objetivo era informar-me detalhadamente sobre a experiência piloto deles em alfabetização de adultos. Foi esse contato que levou a mim e minha então mulher, a fundar em São José do Rio Preto, nos fins de 1962, inicio de 1963, o MCP local. Tenho que salientar que este não teve qualquer ligação institucional com a Faculdade, e que, se bem me recordo, nenhum outro docente da Faculdade chegou a fazer parte. Em contrapartida, participaram duas ou três dúzias de estudantes, e foram estes que se encarregaram da única atividade que chegou a concretizar-se, ou 
seja, um ou dois grupos de alfabetização em fazendas próximas a São José do Rio Preto.

Sei que na mesma altura se fundou o GRUTA, e se a memória não me falha, este foi animado pelo Orestes Nigro. Mas confesso que não tenho qualquer recordação concreta do GRUTA, que tão pouco deve ter tido uma ligação institucional com a FAFI. Não houve entre o GRUTA e o MPC nem ligação institucional, nem informal, para além daquilo que uns e outros poderiam chamar de contatos pessoais.

Em 1962 ou 1963, aparece em cena a AP (Ação Popular), um movimento expressamente político que se originou em Belo Horizonte e cujo núcleo central (original) provinha em geral da JUC. Vi a AP mencionada em dois ou três livros sobre a época, mas em todos os casos com informações escassas e defeituosas. Não tenho tempo e nem elementos para fazer aqui uma reconstrução da $\mathrm{AP}$, que existiu na clandestinidade durante vários anos, depois do Golpe Militar de 1964. O que acho importante esclarecer é apenas que a AP desenvolveu uma ideologia não marxista "de esquerda" que em retrospectiva, foi, a meu ver, mais intuitiva que consistente; entrou de imediato em choque com o PCB, o PCdoB, o POLOP etc., etc.; que teve rapidamente uma forte implantação nas universidades onde conquistou a presidência da UNE, na pessoa do José Serra; que se lhe agregaram, de forma por vezes pouco definida, uma série de intelectuais, inclusive Fernando Henrique Cardoso; que começou a ter uma presença significativa entre os sindicatos rurais que estavam em articulação, especialmente no Nordeste; que se engajou a fundo no movimento de cultura popular; que não teve qualquer penetração nos sindicatos urbanos, sejam os operários ou outros.

Foi a AP ainda em constituição que entrou em contato comigo depois de o MCP de São José do Rio Preto estar constituído. Ficou decidido que eu constituiria uma seção da AP em Rio Preto. Nesta entrou não apenas o pessoal do $\mathrm{MCP}$, não o MCP enquanto instituição, mas uma série de outras pessoas. Geralmente estudantes da FAFI e alguns poucos docentes, entre eles o Flávio di Giorgio e o Orestes Nigro, sendo que este último transitou mais tarde para o PCdoB quando este apareceu na região. Cheguei a fazer parte, pelo Estado de São Paulo, da direção nacional da AP e 
também coordenei a dúzia e meia de núcleos de cultura popular que se constituíram por todo o estado, majoritariamente com afinidade com a AP, alguns de inspiração do PCB.

É preciso dizer que a seção de Rio Preto não chegou durante sua breve existência (não sobreviveu ao golpe militar), a desenvolver qualquer atividade para além, da já mencionada, alfabetização de adultos.

Nem a AP ou o MCP chegaram a ter sede, o que havia de documentação ficou acumulado na minha casa. Quando o Golpe Militar se anunciou, queimei toda a papelada da $\mathrm{AP}$, e tenho a impressão de que a polícia local não só não chegou a saber da existência dela, como nem sabia que no Brasil havia uma organização chamada AP.

A documentação do MCP ficou inicialmente na casa de uma estudante de cujo nome não recordo, e que não tinha qualquer envolvimento; sei que ela depois ficou com medo e que minha então mulher organizou a remoção e a destruição do material.

A AP e o MCP deixaram, praticamente de imediato, de ter qualquer existência efetiva em São José do Rio Preto, depois da minha prisão quando veio o golpe.

Sei que da FAFI, alguns poucos professores, lembro-me do Orestes Nigro e do Eduardo Cañizal, e talvez uma dúzia de estudantes ficaram presos, mas não na prisão comum, mas num edifício administrativo contíguo a esta, de construção recente e que não estava sequer mobiliado. Passávamos os dias a fazer música, jogar cartas e dominó, mas com poucas leituras e conversas sérias. A alimentação era assegurada por familiares e amigos que a vinham trazer, e como os guardas não levavam suas funções muito a sério ("Os senhores ainda vão ser nomes de ruas em Rio Preto", disse um deles), ficávamos sabendo o que se passava lá fora, e tivemos a possibilidade de transmitir recados e até de enviar cartas.

Houve alguns interrogatórios por um delegado, perfeitamente educado e até entediado, no sentido de já ter se convencido de que eram absurdas as acusações que corriam pela cidade e que nos imputavam, isto é que estaríamos preparando uma 
intentona comunista armada, afirmando a rádio local que no sótão da minha casa tinha sido encontrado um depósito de armas...

Durante toda esta fase, o único ato de intimidação que houve foi um dia de prisão solitária que passei a mando de um sub-delegado que "não ia com a minha cara", e cuja ordem foi logo anulada. Não houve qualquer tortura, nem ameaça de tortura. Fui transferido para o DOPS, provavelmente, porque havia uma idéia fantasmagórica de eu ser um agente internacional comunista; a transferência fez-se numa viatura da polícia, com o tal sub-delegado à paisana e dois policiais fardados, os quais estavam visivelmente constrangidos com a encenação toda e até me pagaram uma bebida numa parada...

Fui libertado pelo DOPS porque consideraram que a papelada transmitida pela polícia de São José do Rio Preto não constituía base para nada e porque o Consulado-Geral da RF Alemanha em São Paulo, alertado pela minha então mulher, os contatou e os convenceu de que as acusações não tinham fundamento. Este último ponto não deve, no entanto ter ficado totalmente claro: poucos dias depois de eu ter alugado uma casa em Belo Horizonte apareceu lá um oficial do exército "apenas" para dizer que "eles" sabiam onde eu me encontrava...

Isso é tudo... deve haver mais, mas minha memória já não alcança essa jurássica parte da minha vida. 


\section{CELSO ABADE MOURÃO}

Esta entrevista com o Professor Celso Abade Mourão foi feita pela Professora Nilce Aparecida Lodi no ano de 1978 em São José do Rio Preto. Como o referido professor é falecido, a Professora Nilce, gentilmente, permitiu que eu a utilizasse, a mesma foi transcriada para obedecer a prática da História Oral utilizada pelo Neho, uma vez que ela é de suma importância para este trabalho.

O período de maior dificuldade de relacionamento, tanto com o corpo docente como com o discente, ocorreu em torno de 1961, durante cerca de dois anos. Não sei se poderíamos falar de dificuldade e facilidade de relacionamento ou deterioração de relacionamento. Acho que a segunda alternativa se ajusta melhor à situação.

Meu nome é Celso Abade Mourão, nasci em Leme, interior de São Paulo, me formei em 1954 na USP, sou casado e tenho dois filhos.

A razão da minha vinda para lecionar na Faculdade Isolada de Rio Preto, logo que ela foi fundada, tem duas respostas. Uma curta: fui convidado e aceitei; e uma longa: Depois de licenciado, prestei concurso de ingresso ao magistério secundário e escolhi Cadeira em São José do Rio Preto e Uchoa. Já em 1956, quando começa a história da Faculdade, fui procurado pelo professor Rafael Grisi, por indicação do doutor Michel P. Sawaya, para vir trabalhar na Faculdade. Lembrei ao professor Grisi da conveniência de falar com outras pessoas que, na minha opinião, estavam mais credenciadas para trabalhar no ensino universitário. Apontei a ele os nomes de Pedro Henrique Saldanha, de Luiz Edmundo Magalhães e talvez mais alguns outros. Disse-me ele haver formulado um convite ao Luiz Edmundo Magalhães, mas este não havia aceitado. Vi, então, que o convite se endereçava a pessoas de nível de formação igual ao meu, isto é, gente recém-formada, ainda sem nenhuma 
qualificação especial para o magistério superior. Entendi que se eu não o aceitasse, ele seria formulado a pessoas nas mesmas condições que a minha e que ninguém poderia fazer o melhor que eu, mas, no máximo, igual. Foi essa a razão de eu ter aceito o convite.

Com relação ao corpo discente da faculdade devo dizer que houve uma época em que a facilidade de relacionamento foi muito grande e houve um período em que houve dificuldade de relacionamento, com grupos do corpo discente. Com o corpo administrativo em geral, o relacionamento sempre foi bom, e não houve dificuldades, exceto com algum funcionário, quando eu não me mostrava satisfeito com o serviço prestado. Procurava, então, usar todos os meios ao meu alcance, para melhorar o trabalho do funcionário.

Com relação ao corpo docente, desde que estou na faculdade, do seu início até hoje, sempre tive meus colegas, os que são meus amigos, os que parecem não ser amigos - não sei também se são inimigos - e os que eu diria indiferentes, um relacionamento amistoso, de conversação, mas não propriamente no nível de amizade.

Quanto ao período de maior dificuldade de relacionamento, tanto com o corpo docente como com o discente, ocorreu em torno de 1961, durante cerca de dois anos. Não sei se poderíamos falar de dificuldade e facilidade de relacionamento ou deterioração de relacionamento. Acho que a segunda alternativa se ajusta melhor à situação. Sempre contei com o apoio das direções da faculdade, desde o início até hoje. Aliás, nessa relação diretor-professor sempre há os satisfeitos e os insatisfeitos.

Vou relacionar alguns pontos positivos e negativos das administrações da Faculdade desde a minha vinda até 1970. Vou começar da frente para trás:

- Na administração do Doutor Michel P. Sawaya, um aspecto positivo, porém negativo, foi a criação do curso de licenciatura em Ciências; o negativo foi a não implantação do Departamento de Genética. 
- $\quad$ Na administração do Doutor Duarte, embora ele não tivesse entrosado com a vida universitária, um aspecto positivo dele- e duvido que alguém conseguisse fazer o mesmo - foi criar pacífica e tranqüilamente um bom ambiente nessa escola, sem atitudes que se poderia esperar de um diretor-interventor como ele o foi; como aspecto negativo, questão decorrente da sua falta de vivência universitária: aplicação de rescisão de contrato a não doutores.

- Doutor João Dias da Silveira: o aspecto positivo foi uma adequação desse prédio, derrubando e levantando paredes, mudando a estrutura do prédio de maneira a torná-lo menos inadequado; aspecto negativo: uma perda, pelo menos aparente do domínio da situação.

- Quanto a administração de Rafel Grisi: aspecto positivo: a biblioteca, que conta atualmente com quase 40.000 volumes. Se nós fizermos um levantamento do crescimento da biblioteca em cada uma das administrações, verificaremos que a biblioteca da Faculdade de Filosofia já começou grande e assim começou porque o professor Rafael Grisi a criou grande. Quanto à qualidade do material, porque quantidade, mas de má qualidade não é vantagem, dizem que a biblioteca não valia muito a pena, porque a qualidade não era a das melhores. Acho que ninguém tem o direito de dizer isso, pois numa biblioteca cabe qualquer livro, por essa razão, esse eu considero um ponto positivo. Ponto negativo na administração de Rafel Grisi: ele poderia estar presente em Rio Preto mais do que esteve.

Dizer ser um ponto negativo da administração do Doutor Miguel P. Sawaya criar o curso de Licenciatura em Ciências é uma posição, à primeira vista pelo menos, que parece esquisita, porque não houve a contratação de nenhum professor e nem compra de mais equipamento; então tudo aquilo que era realizado pelo grupo de História Natural; por isso vou justificar a minha posição e não pretendo esgotar meus argumentos nesse sentido. Em primeiro lugar esse curso é muito mal estruturado, muito mal idealizado e teria sido melhor não tê-lo criado na faculdade de São José do Rio Preto; em segundo lugar, agora já como aspecto específico dessa Escola, esse curso se constituiu numa carga a mais para o corpo docente do curso de História 
Natural e com um equipamento, esse mesmo grupo de pessoas teve que estar a serviço de dois de natureza muito diversa.

Outra questão importante é a participação dos alunos nos problemas da Escola e vou dividi-la em duas partes:

Primeira: Participação dos alunos nos problemas da Escola como membros de órgãos colegiados; deve e pode haver essa participação, pois entendo que eles têm contribuição a dar, mas do modo como tem funcionado, a participação deles têm sido mínima, pelo menos no que tenho observado em reuniões de congregação atualmente, algumas do Conselho Superior a que tenho assistido, e algumas de Departamentos, a participação deles é insuficiente. E se considerar que os estudantes sempre lutaram por essa participação, vemos que eles ganharam um brinquedo e não brincam com ele, ou pelo menos não brincam como gostaríamos que brincassem; o que quero dizer com isso é que eles não se informam bem das coisas para depois dar uma opinião. Em resumo: parecem não estar preparados para essa participação.

Segundo: Os alunos não sabem encarar certos problemas da Escola. Estou muito preocupado com a mudança da Faculdade para o prédio novo que vai começar a funcionar em salas de aula com mobiliários novos, e não tenho dúvidas (levantei esse problema ontem na Congregação), que depois de 15 ou menos dias de aulas, as carteiras vão estar cortadas, rabiscadas e riscadas. A falta de zelo pelo patrimônio da Escola, como pelo próprio aspecto da Escola. Os estudantes (certamente professores e funcionários também), sem dúvida contribuem para manter essa Escola suja e isso é uma questão de mentalidade que precisava ser feita antes de nos transferirmos para outro prédio; senão, logo o prédio novo vai ficar ruim. Esta questão de conservação de material é um problema da Escola e disso os estudantes absolutamente não participam, não tomam consciência.

Quanto à participação dos alunos nos problemas da Escola ao longo de sua vida: houve época em que os alunos pretendiam ser capazes de participar, opinando sobre uma série de coisas eles superestimaram sua capacidade de participação e aí 
houve muito palpite sem haver conhecimento de causa. Isso demonstra que eles não estavam preparados e continuaram se preparar para dar sua contribuição.

Veja, embora eu ache positiva a contribuição do diretório acadêmico, ela não é substancial para a elevação do nível intelectual dos alunos. Eles fazem cada vez menos o que deveriam fazer: estudar. O nível dos alunos dessa Faculdade tem caído de ano para ano. Quando das primeiras turmas dessa faculdade os estudantes se utilizavam de meia dúzia de livros que poderiam ser em francês, inglês ou espanhol.

A evidência disso é que eles tiveram uma boa formação e é fácil verificar isso, observando em que situação estão atualmente os alunos da faculdade, das primeiras turmas. Depois o ensino foi degenerado, em conseqüência do aumento do número de alunos, que não foi acompanhado nem pelo aumento de equipamento, nem pelo aumento do número de professores; e se houve aumento não foi em proporções de modo a atendera demanda discente e atualmente os estudantes de Citologia, Genética e Evolução usam, quando muito, um livro há quase como que uma imunização a qualquer livro que não seja escrito em português. A contribuição positiva para elevação do nível intelectual da Faculdade que o estudante pode, e deve querer dar, é estudar mais. E o nosso estudante tem estudado cada vez menos, tenho certeza absoluta disso. Desde o começo da Faculdade, sempre achei que o aluno dispersou a atenção que ele deveria dirigir ao estudo, para outras coisas. E se continua assim é porque as coisas deixaram de ser umas e passaram a ser outras. Houve época em que a dispersão do tempo para outras coisas que não estudo, era um interesse muito grande por uma vida política, seja interna da Faculdade, seja de âmbito nacional e internacional. Se atualmente a gente pode entender que, pelo menos houve uma diminuição desse tipo de interesse, passou a haver um aumento de interesse do aluno por outro tipo de atividade: é a preocupação dele querer dar mais aulas no secundário, do que ele deveria, como estudante. Certamente, o aluno como estudante, deve dar aulas e ele pode fazer isso melhor que o leigo que não tem faculdade de Filosofia. O errado é que em vez dele procurar dar, digamos, 12 aulas por semana, logo no segundo ou no terceiro ano de Faculdade assume compromisso 
de 40 aulas, se não mais do que isso. Parece ser esse um problema já abordado pela legislação, de modo que é de se esperar uma melhoria: só esta questão do colégio não poder atribuir aulas ao estudante de faculdade se houver incompatibilidade de horário, já foi um grande passo, mas há mais coisas que ainda devem ser feita.

Percebo também rivalidades entre os cursos da Faculdade criados em 1957 e também entre os criados após 1968.Vou dividir em duas partes: Rivalidade entre cursos novos e já existentes. Houve e talvez agora um pouco mais (não sei se o termo é rivalidade), gerada pela criação do Curso de Licenciatura em Ciências. Ela existe entre alunos de Licenciatura em Ciências, de um lado, e História Natural do outro; Licenciatura em Ciências de um lado e Matemática do outro. Isto também serve de argumento para justificar porque foi um erro a criação do Curso de Licenciatura em Ciências, porque acho que são (como chamo) "monstrinhos" e um "monstro" que está se hipertrofiando cada vez mais. Isso decorre da estrutura do Curso de Licenciatura em Ciências que dá ao licenciado mais atribuições do que ele é capaz de desempenhar. Ele é legalmente credenciado a dar aulas de Matemática no primeiro ciclo; essas deveriam ser atribuídas aos licenciados em Matemática. Esse deve ser o foco de rivalidade entre Licenciatura em Ciências e Matemática.

O foco da rivalidade entre Licenciatura em Ciências e História Natural vem também dos diretórios legais do licenciado em Ciências. Como o número de licenciados em História Natural não é ainda suficiente para preencher as necessidades do mercado de trabalho, então há disputa entre os dois tipos de licenciados e, também entre os dois tipo de alunos da Faculdade por aulas do segundo ciclo. Acontece que, pelo sistema de atribuição de pontos, não é raro o licenciado em Ciências conseguir vantagens sobre o licenciado em História Natural. É possível colecionar uma série de exemplo, mas no momento não me ocorre nenhuma. Então, aqui rivalidade tem como causa a criação de um curso que nunca deveria existir no país inteiro, nunca deveria Ter sido inventado, tal como foi inventado, o curso de licenciatura em Ciências. 
Quanto a outro tipo de rivalidade em épocas passadas, não era propriamente rivalidade, mas o confronto entre o tipo de atividade que era exercida por alunos de História Natural e alunos de Letra e Pedagogia. O confronto das atividades de História Natural de um lado, e Pedagogia e Letras do outro, é que enquanto os alunos de Letras e Pedagogia tinham aulas um só período, os alunos de História Natural tinham aulas em dois períodos. Então, sobrava muito tempo para alunos de Letras e Pedagogia fazerem uma porção de coisas, não acontecendo o mesmo com os alunos de História Natural . Conseqüentemente, pode ter surgido uma dúvida na cabeça dos alunos de História Natural: “Nós estamos gastando mais tempo em estudos; será que está certo isso, será que nosso tempo de estudo também não deveria ser menos?" Mas eles estavam sempre conscientes da necessidade de participação na vida de estudo da Faculdade. Sempre há exceções em toda situação. E talvez houvesse um descontentamento por parte dos alunos de Letras e Pedagogia pelo desinteresse de alunos de História Natural nas atividades que eles exerciam por ter menos aulas dentro da escola.

Quanto à palavra descontentamento, pode ser que seja descontentamento mesmo, ou outra coisa. Quanto ao desinteresse do aluno de História Natural porque ficando no laboratório o dia todo ( e havia condições materiais para aulas práticas muito eficientes no começo da Escola, muito mais do que hoje) estavam dirigindo a sua atenção para aquilo a que deviam mesmo dirigir, quer dizer, estavam procurando se formar da melhor maneira possível. E, quanto melhor formado estiver o indivíduo, melhor, depois de licenciado, a contribuição que ele pode dar ao país.Acredito firmemente que a instalação da Faculdade de Filosofia, Ciências e Letras trouxe benefícios à cidade e região e focalizando mais as conseqüências do Curso de História Natural. Os cursos de Letras e Pedagogia também tem dado a sua contribuição e posso dizer somente alguma coisa pelo menos conhecimento que tenho desses cursos. Por exemplo, do curso de Letras e Pedagogia há uma porção de Colégios na região cujos diretores são licenciados por essa Faculdade e efetivos na direção. É uma contribuição positiva para a cidade e região. No caso de Letras, há exalunos nossos dando aulas por aí, não só no secundário, mas também em outras 
Faculdades particulares, etc. Com relação à História Natural, o ensino de ciências na região melhorou muito, depois da instalação do curso de História Natural. Sinto que possa estar piorando como conseqüência da criação do Curso de Licenciatura em Ciências, entre outras causas; mas isso não é um pecado da Faculdade, mas do curso estar mal estruturado, melhor seria fechar todos eles...No nível do ensino superior, a Faculdade de Filosofia de Votuporanga, por exemplo, tem no seu corpo docente exalunos e professores desta Faculdade.

Houve uma época em que nossa Faculdade não era bem vista pela comunidade e essa época coincide, mais ou menos, com o período de 1960 a 1964, embora se deva dizer que mesmo nessa época a Faculdade era muito bem vista por parte da Comunidade. Atualmente a Comunidade não vê a Faculdade como deveria; a Comunidade sempre tem demonstrado desinteresse quase completo pela vida de nossa Escola; poucos sabem o que acontece aqui e ninguém procura saber. É claro que há honrosas exceções; mas a maioria desconhece.

Antigamente, tínhamos prazer de trazer conferencistas, pois o salão nobre estava sempre cheio; de repente começou a cair a freqüência a tal ponto que, agora quando vêm um conferencista podemos contar as pessoas que estão assistindo e se verificarmos quem são elas, concluímos que são: o professor que convidou o conferencista, a esposa dele, os colegas de trabalho com suas respectivas esposas ou maridos e alguns amigos que se reúnem para escutar. Então isso criou, pelo menos em mim, um desinteresse total para convidar conferencistas.

Antigamente, de um modo geral, a Faculdade não era bem vista. A idéia de que o ambiente aqui era de agitação política se generalizava. Disse também que deveria haver gente na Comunidade que achava estar muito bem assim; sempre há os a favor de um estado de coisas e os contra. Com relação à época atual deve haver a mesma coisa: de um modo geral, a Comunidade acha que o ambiente da Faculdade é sadio, de preocupação com trabalho, mas acredito que há também aqueles que não concordam com tal situação. 
Quanto ao fato da Faculdade de anteriormente não ser bem vista pela Comunidade, por entender que nela havia um ambiente de agitação política, precisamos distinguir dois aspectos: entre aquilo que se dizia e o que ficou realmente provado ou não ficou provado. Mas falava-se não só de agitação política, como também de um ambiente pouco recomendável do ponto de vista moral. Essa segunda parte, tanto quanto eu sei, nunca foi demonstrada e os comentários eram muito generalizados. Não tenho pessoalmente nenhuma prova de que isso tenha ocorrido.

Não há dúvida que existiram, existem e sempre existiram grupos. Esses podem e devem existir. O importante seria que cada um tivesse consciência de uma coisa: não vou atrapalhar ninguém e que ninguém me atrapalhe; dessa maneira a existência de grupo será até salutar, mas nem sempre isso acontece. 


\section{HÉLIO LEITE DE BARROS}

Estive com o Professor Hélio em sua residência, um apartamento transformado em loft na Pompéia e repleto de obras de arte produzidas por ele. Coisas muito interessantes utilizando material de reciclagem, a maioria de plástico. Conversamos longamente...

\section{"O homem vira homem quando ele diz eu"}

Meu nome é Hélio Leite de Barros, fui professor, hoje sou artista plástico, cineasta... em 1971 fiz um filme com o Roberto Santos que foi selecionado pelo Itamarati para ir ao festival de Berlim, mas depois... a censura, os milicos não deixaram porque era... bem... a gente ganhou um prêmio do governador do estado, era um filme coletivo e fiz uma das partes... nem gostei muito da parte que fiz... sabe, eu estou querendo voltar ao cinema aproveitando as novas tecnologias digitais que facilitam muito as coisas. Essa novidade cria a possibilidade de se fazer cinema sem a necessidade daqueles esquemas de produção complicados que precisam de muito dinheiro, equipe, câmeras pesadas... comprei uma dessas filmadoras de última geração e tenho filmado minha neta para praticar... é muito bom filmar criança, interessantíssimo, elas falam coisas muito interessantes...

Quando a criança começa a falar vira gente, como dizia Hegel "o homem vira homem quando ele diz eu". Quando se fala surge a consciência, surge a distinção entre o eu e o resto e passamos a fazer parte de uma comunidade. Tenho uma neta maravilhosa, inteligente, sensível... minha relação com ela não é apenas aquela entre avô e neta, vejo nela uma fonte de conhecimento humano... creio que sou um avô muito coruja. 
Quando estou com ela lembro do período que lecionei em Rio Preto... eu falava sobre o outro, comunidade, filosofia da linguagem há 40, 50 anos nas aulas de Filosofia e Pedagogia... algumas coisas eu havia esquecido e ela está me ensinando novamente... estou vendo surgirem nela a inteligência, isto é, as funções cognitivas na sua maior pureza. Vejo surgir também os impulsos básicos como agressividade, amor, carinho... isso é muito bom.

Tenho 3 filhos e dois netos. Uma neta de 20 anos do primeiro casamento e outra de 4 anos do meu segundo casamento e... não, não estou no terceiro casamento... separei-me da minha segunda esposa e estou sozinho... tenho apenas dois filhos do primeiro casamento que nasceram pouco antes de eu ir para Rio Preto, minha filha também se casou duas vezes... hoje isso é normal... é muito difícil viver com uma pessoa durante muito tempo, conheço até alguns casos que dão certo, mas cada vez vale menos como regra, não sei se é bom ou mau... aí é outra história... mas enfim...

Nasci na cidade de São Paulo, em 1929, no bairro do Canindé, minha família é muito numerosa, minha avó materna teve quinze filhos, imagine que ainda existe um com 103 anos... está numa clínica, suas funções mentais estão muito avariadas... A memória dele é do passado.

Estudei no Grupo Escolar Santo Antonio do Pari que era excelente... hoje houve no ensino, de um modo geral, uma decadência da qualidade enorme... Quando sai de Rio Preto voltei a dar aulas de Filosofia em colégios estaduais, um em Osasco, já não era bom... bem, talvez minha visão fosse muito crítica... lembro até hoje das minhas professoras, a dona Eudorina, a dona Neusa, que era uma mulher muito afetiva, muito gorda... imagine que nas férias ela levava alguns alunos para ficar na casa dela... hoje essa relação professor/aluno se perdeu. Sabe, nesse período a mulher ou era professora ou prendas domésticas... não havia quase opções, só que como professoras elas ganhavam bem, 3 ou 4 vezes o que se ganha hoje, então o homem também podia sustentar sua família sendo professor. As professoras, normalmente, eram filhas de famílias ricas. 
Depois que saí do grupo escolar fui para um curso básico comercial, meu pai achava importante aprender uma profissão... sempre tivemos algum dinheiro... eu tinha família em Itapetininga que sofreu na crise do café, outra parte da família era de Mirassol... minha mãe teve 11 filhos... era complicado sustentar todo mundo... por isso fiz o técnico comercial ao invés de fazer o clássico, assim poderia me colocar no mercado de trabalho mais rapidamente... comecei a trabalhar com 11 anos num armazém de seco e molhados perto da minha casa e podia ajudar meus pais com um dinheirinho... eu não queria fazer o tal básico comercial... uma coisa chatérrima, parecia coisa de gente menos dotada de inteligência, não precisava pensar e era ruim. Eu era muito curioso... tinha uma curiosidade imensa pelo conhecimento... tinha vontade de crescer intelectualmente, então depois de dois anos no comercial arranjei um jeito de fazer o colegial clássico... fiz madureza por correspondência e fui para a faculdade de Filosofia. Quem me incentivou foi um professor de matemática que também era filósofo, falava sobre os mais diversos assuntos, inclusive de religião, da existência de Deus... ele me disse que isso se estudava no curso de Filosofia e aí eu me apaixonei por Filosofia... meu lance era desvendar os enigmas do mundo.

Hoje o ensino está decadente e o começo dessa decadência do ensino secundário foi em 1969 com a Reforma Passarinho, uma das piores coisas que aconteceram neste país foi o Jarbas Passarinho na educação, ele implantou o acordo com o USAID, veio aquela coisa de ensino técnico para formar mão-de-obra barata e não pensante... foi um arraso, acabou com o ensino nesse país, acabou com a Filosofia, com o Latim, com Francês... uma mudança estúpida, a aniquilação da formação de consciência critica, de visão de mundo... esse tipo de ensino ficou restrito a algumas escolas particulares caras, de elite.

Nesse período do clássico eu costumava freqüentar a Biblioteca Municipal Mário de Andrade, lá encontrava amigos intelectuais, poetas... a livraria tinha um excelente acervo de arte e era dirigida pelo Charles Nemet. Havia umas cabines onde podíamos estudar, apresentar projetos, gostava de ir à museus que possuíam coleções de obras bem diversificadas, meu favorito era o Museu de Arte Moderna, à Cantina do Marinheiro que existe até hoje. Havia também um clube de cinema 
dirigido pelo Paulo Emílio Sales Gomes que foi um grande critico e intelectual. Era um homem charmoso, inteligente, conhecia muito de cinema, havia estudado na França e nas sessões de cinema que ele fazia vi grandes clássicos do cinema francês e americano como Jean Renois, Orson Welles. Tinha o Décio de Almeida Prado, um crítico de teatro que escrevia no Estadão, o Sérgio Lineu, o Antônio Cândido, este último de importância impar na minha formação, ele é brilhante, um grande intelectual.

Não estou fugindo do assunto, mas acho importante falar da vida cultural daquele período para entender nossa formação e o que aconteceu em Rio Preto.

Nesse período surge o Teatro de Arena, o TBC, Teatro Brasileiro de Comédia... tinha a USP... para qualquer cidadão, que como eu, queria conhecimento, São Paulo era maravilhosa, tinha apenas 1 milhão de habitantes, havia bares onde intelectuais se reuniam para discutir, na rua Maranhão tinha um que o Chico Buarque freqüentava. O Caio Prado morava em Higienópolis... enfim havia um universo sem nenhum juízo de valor, era uma cultura superior que se realizava... havia livrarias sensacionais como a Francesa, a Duas Cidades, a Paternon, onde eu comprava muitos livros a prazo. Havia também o Teatro Municipal que frequentei muito com o Mauricio Tragtemberg, o Bento Prado, o Roberto Schwarcz, eram óperas, musicais, recitais, artistas que vinham do mundo todo.

O Roberto ainda está na ativa, um homem que pensa o Brasil muitíssimo bem. Conheci o Manoel Carlos, o Maneco que hoje escreve novelas na Globo como ator... ele era péssimo, ele mesmo dizia isso. Conheci também o Rui Fausto, que era irmão do Bóris, o historiador. O Rui era trotskista, e fazíamos reuniões meio silgilosas na casa dele em frente à Praça Buenos Ayres em Higienópolis. Tinha também o Jacó Ginsburg, ele era judeu rico de Higienópolis, já o Mauricio era judeu pobre que morava na Vila Maria Zélia, no Bom Retiro... chamávamos o Mauricio, brincando, de "vaca revolucionária". Ele era da esquerda radical judia...todos desse grupo andavam com casacos de couro...era a juventude socialista judia. 
Sabe a Gilda de Mello e Souza, mulher do Antonio Cândido? Ela é sobrinha do Mário de Andrade, foi aluna do Antonio.

Fiz Faculdade de Filosofia e dei aulas no Colégio Alberto Conti, substituindo o Décio de Almeida Prado, lá o Michel Lövy foi meu aluno e depois foi meu colega em Rio Preto. Depois lecionei no Colégio Roosevelt e lá dei aulas para o Carlos Guilherme Mota, a Marilena Chauí , o Sedi Hirano, o Gabriel Cohn, gente de valor.

Bem a faculdade de Rio Preto foi "inventada" por um "picaretão" chamado Daud, no inicio era municipal, depois foi estadualizada no governo Jânio Quadros e o Carvalho Pinto era secretário... acho que a única coisa boa que o Carvalho fez na vida foi ajudar na estadualização da faculdade de Rio Preto. Claro que a faculdade foi criada por razões de ordem política, para acomodar um grupo de pseudointelectuais sem formação da cidade.

O Jânio estadualizou a faculdade, mas exigiu professores da USP, não queria que a estadualização servisse para politicagem local de um grupo muito sacana, canalha mesmo, que se considerava dono da faculdade. Esse foi o grupo que se aproveitou da Revolução de 64 para tomar a faculdade novamente.

Bem, sob a direção do Rafael Grisi a faculdade quase desandou, uma ilha de corrupção, sorte que lá havia gente muito boa, o Orestes Nigro, o Flávio de Giorgi, a Maria Edith di Giorgi, entre outros e não deixamos a coisa degringolar. Claro que havia os de direita como o Luiz Dino Vizotto, o Celso Abade Mourão, o Coronado de Espanhol, esse último participou da queima de livros após a invasão dos militares. Ele era também da Opus Dei. O assistente dele era o Eduardo Cañizal que foi professor da ECA. Ele não fechava ideologicamente com o Coronado, era mais da turma da esquerda...

Bem, quem me convidou para ir para lá foi o Rodolfo Azzi, sabe que depois da cassação ele virou hippie, artesão? Ele era da cadeira de Psicologia. Fui ser assistente dele. Eu já era casado nessa ocasião, casei em 1954 com a Mary Amazonas Leite de Barros, que também foi professora lá em Rio Preto. Sabe, ainda tenho muita amizade 
com a Mary, ela é mãe dos meus filhos, acho que ficaremos de alguma forma ligados para o resto das nossas vidas, afinal tenho 78 anos...e não acharei ruim se você tivesse imaginado que eu era mais novo... a Mary também está muito conservada.

Sabe, não gosto muito de rememorar essas coisas de Rio Preto, embora eu saiba que é muito importante, é também muito doloroso, uma parte da história da gente que é muito desagradável, que a gente quer esquecer... tem gente que quer lembrar... é a questão da individualidade... cada um é um... ainda bem! Se bem que a individualidade traz o problema da solidão, um terreno meio complicado, acho que no fundo todos nós estamos sós, a gente tenta superar isso ligando-se a outras pessoas... sabe... dizem que Bach era um solitário e por isso fez música, como forma de superar a solidão básica.

Voltando à Rio Preto, foi a primeira faculdade do Brasil que teve representação paritária e isso foi uma grande revolução na educação... também nos valeu a pecha de "comunas" de Rio Preto...a coisa não era engolida pelo pessoal das Ciências Naturais... a única coisa ruim eram as reuniões... sempre achei reunião uma porra...acho que nesses momentos a democracia é meio cansativa... acho que no final das reuniões todo mundo queria dizer:- vamos acabar logo com essa lenga-lenga, mas era muito divertido.

Nunca fui muito de militância política, achava muito cansativo... aquelas digressões, embora tivesse posição de esquerda não gostava de reuniões, gostava, sim, de dar aulas, discutir com meus alunos, de pensar, de escrever... eu tinha relações com pessoas do Partidão, mas não era militante. Admirava a JUC, mas também não militava nela.

Estou percebendo que minha história faz parte da história da universidade brasileira, da realidade socioeconômica desse país... estudei tanto na vida, ás vezes chegava a tomar estimulante...

Sabe, o trabalho em Rio Preto era estimulante, professores de nível muito bom querendo criar uma educação diferenciada. O Casimiro Reis Filho, o Orestes, o Azzi, 
o Cantoni, o Lövy, o Traugtemberg, a Sara, esta última tem uma história a parte, sofreu muito... o Casimiro era espírita... um espírita de esquerda... é até engraçado! Ele era um cara bom, os espíritas são geralmente bons, o que não é o caso dos protestantes, posso falar isso porque minha família é protestante... conheci muitos espíritas bacanas, humanos, generosos.

Bem, nossa classe era muito rica intelectualmente, acho que não havia militantes políticos, mas militantes culturais. A gente queria, representava e procurava fazer algo para acontecer uma transformação na cabeça das pessoas, a gente trazia coisas novas e claro, isso colidia com o padrão reinante que nos taxavam de revolucionários. Agora, havia a militância, o Heimer com a AP, o MPC, era intensa, o Azzi com o partidão... o problema era que os postos chaves da lei em Rio Preto, delegado, juiz etc. eram da direita... então, já viu. Como eu gostava muito de cinema acabei me engajando, dirigia um grupo de cinema. O MPC estava ligado ao GRUTA, ao Ferreira Gullar, ao Augusto Boal, o Guarnieri, ao Juca de Oliveira... o Orestes também era do MPC, participava das reuniões para discutir estratégias...

Lembro de uma ocasião em que passei "O encouraçado Potenkim" e depois houve discussões com os camponeses que participavam do movimento de alfabetização de adultos...

Embora fossemos bastante engajados, foi uma surpresa o Golpe. Claro que esperávamos algum tipo de represália, estávamos mexendo muito com a sociedade, mas o Golpe na faculdade ninguém esperava. O pessoal de direita, que nem de direita podemos chamar porque eles não eram nada, foram apenas oportunistas, se reuniu e aproveitou a oportunidade, o Daud era o principal denunciante e antes do Golpe vinha se reunindo com o Tácito Pinheiro Machado, o delegado geral da cidade que foi uma figura fundamental na invasão, ele estava macomunado com o juiz Duarte, que "coincidentemente" foi ser o diretor da faculdade... bem feito para o Daud que queria ocupar esse cargo.

Havia uma aluna, Yvone de Moura Campos que também denunciou os professores e colegas... tudo por despeito. Ela era medíocre. 
Na faculdade havia uma cadeira de Cultura Brasileira cujo professor, Diego de Souza Antônio era discípulo do Florestan Fernandes e era um líder do pensamento de esquerda, ele morreu jovem, do coração. Havia o Cantoni, de esquerda, o irmão dele era violinista, o Humberto Cantoni... imagine que depois do Golpe, quem pegou a cadeira de Cultura Brasileira foi um advogado da cidade que defendia a tese da inferioridade do índio brasileiro... quer dizer, todo nosso trabalho, anos de estudo, foram desprezados.

O Aluizio Reis de Andrade também foi muito importante, o Newton Ramos de Oliveira também era demais... o Lövy é marxólogo de renome internacional, porém antes do Golpe ele ganhou uma bolsa e foi para a França, está lá até hoje.

Se o Golpe não tivesse acontecido a faculdade de Rio Preto seria a melhor do Estado de São Paulo, éramos de ponta, algo novo, uma força inovadora, um trabalho de excelência, ousada, teria transformado Rio Preto... poderia ter sido uma coisa muito positiva... hoje decaiu muito, não só ela, mas o ensino de uma maneira geral. Poderia ter sido... mas não foi... uma pena! 


\begin{abstract}
ANOAR AIEX
A carta abaixo transcrita me foi enviada pelo professor Anoar Aiex após o meu contato com ele por telefone. O Professor não quis fazer uma entrevista via computador, uma vez que, como ele me disse, não gosta de mexer com tal máquina. Como considerei importante o teor da mesma para este trabalho, resolvi, com a autorização do professor Anoar, transcrevê-la e juntá-la às outras entrevistas, seguindo o mesmo padrão de análise que desenvolverei com as últimas feitas oralmente.
\end{abstract}

Estava, no entanto, tão deprimido pelas demissões e prisões dos meus colegas e pela destruição de tudo que estávamos tentando criar em nosso departamento. Por isto, resolvi sair do país e procurar trabalho aqui, nos Estados Unidos.

Baseando-me exclusivamente em minha memória, que, infelizmente, não é muito acurada sobre acontecimentos ocorridos há quase 50 anos, tentarei descrevêlos da seguinte maneira: Comecei a trabalhar em Rio preto, na cadeira de Filosofia, do departamento de Pedagogia, que estava organizado democraticamente, isto é, a participação era paritária entre alunos e professores que tinham o mesmo direito de voz e voto.

Esta inovação foi bastante significativa, pois criou grande dinamismo e responsabilidade de todos os participantes do departamento. O desenvolvimento e as inovações curriculares que estavam sendo processadas foram, abruptamente, interrompidas pelo Golpe Militar de 1964, em que a repressão iniciada à nível nacional, foi arbitrariamente executada pela autoridade local. Em Rio Preto, por exemplo, o delegado aceitava denúncias anônimas, levando-o a aprisionar inicialmente membros do corpo docente, e, mais tarde, do discente. 
Dessa perseguição, em parte anticomunista, em parte simplesmente ressentimento local contra uma Faculdade repleta de "bárbaros" da Capital, resultou a demissão de vários colegas e do desmembramento do departamento de Pedagogia. Eu fui demitido num segundo grupo por não ter completado a minha tese de doutoramento. Poderia ter entrado com um requerimento pedindo mais prazo para completá-la, pois era impossível trabalhar numa tese num clima tão instável. Estava, no entanto, tão deprimido pelas demissões e prisões dos meus colegas e pela destruição de tudo que estávamos tentando criar em nosso departamento. Por isto, resolvi sair do país e procurar trabalho aqui, nos Estados Unidos.

É isso que tenho a dizer.

Abraços

Anoar.

OS. Dê, por favor, meu abraço ao Orestes. 


\section{SARA ROTTEMBERG}

Estive com a Professora Sara em seu apartamento localizado próximo ao estádio do Morumbi. Senhora simpática, alegre e de força de vontade incrível. Ela havia sofrido um derrame há poucos meses, utilizava uma bengala, mas vive sozinha, embora, segundo ela, os familiares estejam sempre por perto. Tem um orgulho muito grande por ainda trabalhar como advogada e um olhar saudoso aparece quando relembra os tempos de Rio Preto.

\section{Éramos sonhadores, idealistas.}

Meu nome é Sara Rottemberg. Sou professora. Minha formação deu-se na Escola Caetano de Campos, que era a melhor escola secundária de São Paulo, cuja diretora Carolina Ribeiro, por ser admiradora do Getúlio, ou talvez por ocupar um cargo de confiança e ter que ser conivente com o governo, imprimia à escola uma formação getulista. A função social da Caetano de Campos era formar uma elite, principalmente feminina, que depois viria a ser as esposas de juízes, desembargadores... estudavam lá as filhas das melhores famílias de São Paulo, havia professores altamente qualificados, embora houvesse também os medíocres. As pessoas costumavam falar que as moças que estudavam no Caetano estavam, na verdade, esperando marido... isso é um absurdo, eu mesma não me casei.

Sou brasileira, não sigo religião nenhuma, embora meus pais fossem judeus e eu tenha recebido uma educação com os preceitos da religião judaica... mesmo assim não segui com a tradição do judaísmo... bem... meu pai era liberal... não ligava muito para isso... mesmo assim acho que posso dizer que me considero do grupo judeu... isso não impediu que minha melhor amiga fosse filha de alemães, a Gisela... havia também uma menina chamada Karu Osoi, filha de um médico japonês, havia amigas filhas de italianos... acho que os Spinelli... um grupo de amigas tão diversificado acabou sendo isolado ... havia muita discriminação com filhos de imigrantes... a Karu 
Osoi acabou indo para o Japão e ficando por lá... também, na escola havia quase que só filhas de fazendeiros de café... gente metida. No Colégio Roosevelt não havia esse tipo de problema, era uma escola onde as pessoas tinham a cabeça avançada, lá não era escola normal, era colegial, um povo menos "quadrado".

A Universidade surgiu em São Paulo nos anos 1930 e se consolidou nos anos 1940. A primeira turma é formada na USP por volta de 1940, não me lembro exatamente do ano, e esses primeiros formandos faziam parte dessa elite do Caetano de Campos, não pense você que o povo participou dessa turma, a massa não teve nenhuma participação no início da Universidade. Era uma inteligenttsia que não se espalhava, trouxe muitos estrangeiros, assim houve, na verdade, a valorização do europeu e então os filhos de imigrantes passaram a ser valorizados. Alí, éramos medidos pela nossa capacidade, não por sermos estrangeiros.

No início eu não queria fazer Pedagogia, porém, havia feito o normal e só me restou Pedagogia. O vestibular era tão ou mais difícil que agora, havia prova de latim, de outras línguas... eu me preparei através de um cursinho ministrado pelo grêmio da escola... veja, estou contando toda essa história porque ela é importante para você perceber o tipo de professores faziam parte da Faculdade de Rio Preto... bem, quando fui prestar o vestibular, em latim para todas as disciplinas, exame oral e escrito, caiu justamente Guerras Púnicas em História... foi uma dúvida, mas o professor Marcelo Francisco disse que eu havia passado porque sabia pensar... em Literatura caiu Salúcio, um arcaico do qual nunca tinha ouvido falar, mas como sabia bastante gramática, consegui.

No exame de Literatura Portuguesa caiu um autor clássico... eu só sabia sobre ele o que tinha lido do Rama... e eu ali, fazendo um exame oral, e meu examinador era o Professor Antonio Cândido, um grande literato... tive uma idéia... perguntei a ele se podia fazer uma comparação... comparei esse autor clássico ao Hemingway, falei do livro dele que eu mais gosto, é a história de uma pessoa que se buscou a vida inteira, nunca esteve satisfeito consigo mesmo, deixa de casar com uma moça que gosta muito por causa dessa busca... comparei o personagem de Hemingway ao 
autor sobre o qual eu tinha que falar, pois ele se mata. O professor Antonio Cândido disse: Olha, apesar de você só saber a biografia dessa sumidade da Literatura Portuguesa, você vai entrar na Faculdade, pois foi incrível a maneira como uma menina de 17 ou 18 anos inventou uma história e construiu uma relação entre o fictício e o real, aqui, na hora. Do autor você não sabe quase nada, mas você deve gostar muito de ler, e provou que é capaz.

Cursei Pedagogia, mas Pedagogia mesmo, não isso que se vê por aí hoje. Os professores eram muito capacitados, tínhamos a possibilidade de conhecer outras pessoas, de nos tornarmos seres humanos críticos, tínhamos a UNE, que era muito atuante, éramos amigos dos universitários das outras faculdades da USP e, durante um período, até dos do Mackenzie. No Mackenzie só estudavam os filhinhos de papai, de famílias ricas, donos de bancos... quando fiquei mais adulta me afastei um pouco dessas pessoas, afinal, enquanto a gente é estudante parece que todos são iguais, mas depois... o dinheiro sempre foi a mola da diferença...

Eu estudava muito, sempre queria mais, além das disciplinas da Pedagogia fazia algumas também na Filosofia, nas Ciências Sociais... minha mãe dizia que era melhor eu levasse minha cama e ficasse morando, de vez, na faculdade... eu adorava as aulas do Antonio Cândido...

Quando terminei o curso procurei emprego, precisava trabalhar, já era 1953...Prestei concurso para professora do normal de Sociologia da Educação. Comigo concorreram o Janotti, o Rodolfo Azzi, o Aloísio Nunes Ferreira, pai do atual político, que era advogado e foi um dos que ajudou fundar a Faculdade de Rio Preto. Passei em primeiro lugar. Também concorreu com a gente o Selvin Bailey, que depois foi um grande desembargador, ministro, era muito inteligente, de um comportamento ético exemplar... ainda bem que ele não passou, senão teria sido um professor, ao invés do jurista brilhante.

O exame era oral, mas não tive medo porque fui formada por grandes mestres que me ensinaram... digamos que uma visão socialista...embora na USP houvesse um grupo... digamos que..."quadrado"... eram os das Ciências Naturais... Bem, cada um 
de nós escolheu uma cadeira e fui para Descalvado... sempre fui muito benquista, querida como professora. Eu era muito exigente, procurava participar de tudo na cidade, até dos eventos da igreja, que era pobre... eu não freqüentava a igreja, mas ajudava a promover eventos para levantar fundos, como bailes, quermesses, bem procurava fazer o que estivesse ao meu alcance. Como tinha muito tempo livre, além de estudar, procurava outras atividades, fiz até curso de corte e costura. Havia outras professoras da PUC de Campinas que não sabiam nada... imagine que elas usavam o livro do Teobaldo Miranda Santos para dar aulas, um sujeito que não escrevia nada, só compilava... eu era crítica, exigente, cobrava o português... nem sempre agradava, mas depois de 20 anos, costumava encontrara alunos que diziam:Professora, ainda bem que a senhora era exigente, lembro de tudo que a senhora ensinou, já dos outros professores... sabe esse menino que hoje é presidente da Petrobrás, o Gabrielli, foi meu aluno, ele e o primo.

De Descalvado pedi remoção para o Vale do Paraíba, a cidade era Cruzeiro. Também fiz muitas coisas lá, até na área de História, fiz uma exposição de todos os utensílios de cozinha usados desde a monarquia até a época do Adhemar de Barros... também estudei a chegada de imigrantes italianos por lá... nessa empreitada tive a ajuda da Nô, Leonor, casada com o Márcio Thomaz Bastos, grande jurista, ministro... estou contando isso porque é muito importante para as pessoas entenderem minha formação. Conheci até a Ângela Maria, aquela que canta Babalu, em Cruzeiro. Ela foi fazer um show lá. Foi nessa época, em 1956, que fui convidada para lecionar em Rio Preto. Recebi uma cartinha, num papel pequeno, folha de caderno, escrita a mão do Wilson Cantoni para dar aulas lá. Levei a idéia para os meus pais que disseram que eu fizesse a escolha, afinal, se eu fosse feliz eles seriam felizes também... por aí você como meus pais eram especiais.

Meu pai era um homem aberto, tinha idéias socialistas, nós não tínhamos muito dinheiro, quando ele nasceu minha avó morreu e o pai dele, como bom judeu casou-se com a cunhada... era para ele ter feito direito em Moscou, meu tio mais velho havia feito engenharia em Praga e foi um bolchevique... mas meu pai veio para o Brasil em 1914, aqui ele conheceu minha mãe e casou-se com ela, os judeus 
estavam saindo para os Estados Unidos, para Amsterdan... a família era dos Weinstock de Nova Iorque... o medo da guerra, porém, fez com meu avô e pais pegassem o primeiro navio que estava saindo do porto e eles vieram para o Brasil. Primeiro foram para Ribeirão Preto onde meu tio tinha uma farmácia, A Catedral, depois viemos para São Paulo, meu pai, minha mãe, meu irmão e eu. Se meu pai tivesse que comprar uma coisa para casa ou um quadro, com certeza, compraria o quadro. Ele amava o belo, não tinha emprego fixo, mas trabalhava muito, nunca nos faltou nada... ele contava muitas histórias e me arrependo de não tê-las anotado... era anticlerical, gostava de contar histórias sobre rabinos... e o rabino nunca se dava bem...essa formação que veio do berço pesou muito na minha vida.

Fui para Rio Preto em 1958. Quase todos os professores de lá queriam formar uma escola com características bem brasileiras, queríamos nos livrar dessa coisa européia e buscar as raízes para uma formação brasileira, como pensava o Darcy Ribeiro que a gente conheceu muito, assim como a turma do Ceará... elaboramos, então um plano de escola e convidamos todos que quisessem se agregar. Éramos sonhadores, idealistas. Todos os professores da Filosofia, Letras e Pedagogia se agregaram... o Norman, o Orestes, Cantoni, entre outros... o pessoal da Biologia, Zoologia, enfim Ciências Naturais não aceitavam nossas propostas.

Começamos a trabalhar cada um no seu setor, tínhamos seminários diários de estudo para construir a escola que a gente imaginava... foi uma revolução o método que a gente começou. Pensávamos em formar uma escola com a predominância no sentido evolutivo do pensamento, tudo interligado, Filosofia, Artes, Pedagogia...a idéia era formar um homem brasileiro... queríamos criar a possibilidade para que as pessoas pudessem pensar com mais amplitude... logo pensamos em teatro, o Orestes adorou a idéia... formou-se o GRUTA. Não éramos só professores, no sentido da palavra, queríamos mais... uma formação completa.

Rio Preto era o centro comercial da região, havia uma elite, muita fazenda de gado, agricultura... as outras cidades eram incipientes, como Tanabi, Jales, Votuporanga. Rio Preto tinha intelectuais, poetas como o Jamil Almansur Hadad, o 
Mauricio Goulart, grande historiador, o Rui Nazareth, um médico e também político que se juntou a nós.

Não entramos muito em contato com a população... a não ser com nossos alunos. Com eles íamos tomar sopa depois das aulas, toda noite, era um relacionamento maravilhoso, éramos os mentores, não só intelectuais, mas de tudo, de hábitos... começamos a mostrar a liberdade com responsabilidade... era natural que fosse diferente dos costumes da cidade... tínhamos uma formação diferente... eu mesma... veja houve um homem que se apaixonou por mim e ficou 11 anos esperando que eu dissesse não... foi persistente, mas era casado, tinha uma filha.. não fui amante dele, mas ele me roubava do trabalho, não das aulas, do trabalho, conheceu meus pais... foi uma paixão que durou muito tempo... tenho cartas e cartas para provar isso. As pessoas diziam que eu era amante dele, mas não fui... ele me chamava de gata, era um romântico... ele era militar e eu detesto militar, só que ele havia feito escola militar por dinheiro, não por idealismo, depois que me conheceu fez Pedagogia e nós dois fizemos Direito, depois da Revolução de 64 fui para a Venezuela trabalhar numa escola rural... quando voltei foi que fizemos Direito em Uberlândia... nunca ninguém soube lá que eu já era professora universitária... estudei e ele estudou por minha causa... foi bonito... mas essa coisa da revolução...

Havia um pessoal de direita lá em Rio Preto, um delegado que era um... um grupo do contra...tinha sido tão difícil o Goulart se tornar presidente e olhe que ele cercou-se de pessoas muito capazes, o Almino Afonso que era um grande pensador, o Paulo Freire... eram pessoas que como nós queriam mudar o Brasil, a Reforma Agrária que já estava sendo aplicada em toda a América Latina, mas ainda era incipiente no Brasil... o Estatuto da Terra que era super importante... a entourage do João Goulart era... era a mudança... era o desejo de igualdade...

Agora, como quebrar uma hierarquia militar, uma estrutura tão enraizada? Só se quebra com uma revolução, aí se quebra o pensamento e o pensamento é o estímulo para poder fazer... infelizmente não estávamos preparados...os estudantes queriam, nós queríamos uma maneira mais igual de viver, de estudar...A 
Universidade estava querendo que todos tivessem oportunidades, a formação que dávamos formava pessoas altamente gabaritadas e seres pensantes... só que nem todos pensavam assim e feriu-se a Constituição.... nós tínhamos que reagir... porém, dentro da faculdade ninguém conversava com ninguém, sabíamos que as paredes tinham ouvidos... conversávamos com os gestos, os olhos... havia tantos dedosduros... começou de fora e entrou na Faculdade... o turco Daud era terrível, pessoas não formadas queriam tomar a faculdade só porque tinham ajudado a fundá-la, claro que em benefício próprio...eram todos professores do Monsenhor Gonçalves, sem formação universitária...com exceção de alguns da área de Zoologia... Esse grupo... o Coelho, o Daud... não se conformavam com a relação que tínhamos com os alunos, queriam a hierarquia e assim como eles, grande parte da população, a elite não aceitava que professores e alunos pudessem aprender concomitantemente... não aceitavam as novidades, os filmes que vínhamos buscar em São Paulo, as discussões, as cervejas no barzinho do Seu Antonio...o Maia que abriu uma livraria onde se vendia os livros de Marx, Engels etc. não aceitavam como transmitíamos o conhecimento...

Havia uma integração grande entre as faculdades municipais do interior, trocávamos informações, idéias... quando o Sartre esteve em Araraquara fomos vê-lo. Depois da Revolução tudo ficou ruim... a própria faculdade... sorte que depois veio o Professor $\mathrm{Ab}^{\prime}$ Saber e foi ele que lutou para que pudéssemos, uma vez que havíamos sido afastados, ao menos, nos aposentar...

Havia um grupo grande de professores que era contra a gente, o Celso Abade Mourão, o Daud, o Vizotto, até o vigilante da escola a quem o Orestes havia arrumado emprego, o Aristides, a Yvone de Moura Campos, essa sim, péssima, a pior de todas... o Edoardo Querim, que a gente acreditava ser inofensivo, mas não era... aquele Coelho que tomou a cadeira do Norman Potter...

O Anoir Aiex, um amigo eterno, foi para os Estados Unidos e não voltou, muito inteligente, casou com uma americana que odiava galinha a cabidela... $\mathrm{O}$ Heimer fundou a AP e fazia parte da JUC, junto com o GRUTA formaram a 
alfabetização de adultos... foram todos presos. Sorte ter o Godói que era aquele meu namorado... ele era militar, brigou com o delegado. Ele era Tenente Coronel, José Ribeiro de Godói, quase perdeu o cargo por ajudar os presos, foi sempre generoso, apesar de ser militar, se não tivesse ajudado... não sei não... Teve um professor que foi o que mais sofreu,o João Cunha... tentei encontrar a esposa dele, a Ieda... eles tinham muitos filhos... ele morreu e ela ficou desamparada com todas aquelas crianças... uma injustiça.

Rio Preto foi a primeira faculdade que sofreu intervenção e creio que isso aconteceu porque eles mediram nossa qualidade... não era interessante para eles... formávamos acadêmicos pensantes e isso não era interessante para a direita, não éramos uma escola clássica com formação clássica, estávamos muito a frente de nosso tempo, não formávamos aberrações acadêmicas como essas que estão por ai. Não basta saber ler e escrever... tem que saber pensar, criticar, agir e isso nos fez servir de vidraça... os medíocres tinham ódio de nós. Depois de nós veio a mediocridade como o Zeferino Vaz (Nhá Zefa) lá da PUC que andava com a braguilha aberta... Rio Preto não estava preparada, não havia classes sociais lá, só uma elite e é assim até hoje.

Acabei lecionando na Venezuela, no CIER, Centro Interamericano de Educação Rural, depois fui funcionária da OEA, Organização dos Estados Americanos, ganhei em dólares, voltei, comprei um apartamento, fiz direito e hoje sou advogada, trabalho até agora, porque se não trabalhar não vivo, afinal minha aposentadoria é mínima... agora estou lutado para ver se a anistia me dá um pouco mais... 


\section{NILCE APARECIDA LODI}

A professora Nilce me recebeu em sua casa, na cidade de São José do Rio Preto numa tarde quente de julho de 2008. Ela estava me esperando com vários documentos sobre a Faculdade, inclusive um boletim publicado por ela. Gentilmente autorizou que eu utilizasse as entrevistas que havia feito anos atrás. Enquanto conversávamos apareceram vários sobrinhos, todos recebidos carinhosamente.

Nós nem imaginávamos que eles, os militares, pudessem olhar para Rio Preto. Foi um choque perceber que a Faculdade era visada, que nossos professores estavam sendo presos.

Meu nome é Nilce Aparecida Lodi. Fiquei na Faculdade muitos anos, desde o início até há pouco tempo quando me aposentei. Hoje as coisas são diferentes, mas acho que a semente o que foi plantado lá atrás germinou. Comecei na Faculdade em 1957, fui aluna da primeira turma. Primeiro tínhamos uma universidade municipal, depois o Jânio estadualizou e transformou-a em Faculdade Isolada de São José , nos moldes de outras já existentes, como Franca, Prudente e Marília. Crescemos, e embora os prédios fossem alugados no início, com o tempo a prefeitura comprou um prédio na rua General Glicério, onde hoje funciona a Secretaria Municipal de Educação. Ficamos lá até 1970 quando foi comprado um seminário que a igreja não tinha dinheiro para terminar. Fomos mudando até que em 1975 percebemos um clima de que haveria mudanças... essa mudança veio de cima para baixo com a criação da UNESP que desorganizou tudo aquilo que tínhamos conseguido organizar nos anos passados.

Bem, voltando a 1957 quando da estadualização, foram contratados professores da USP como o Aloizio Andrade e o Casemiro dos Reis Filho, vieram o Viszotto e o Abade Mourão para o Curso de História Natural. A Faculdade era uma 
reivindicação da população de Rio Preto, era difícil mandar seus filhos estudarem na USP em São Paulo, são mais de 400 quilômetros... Muita gente achava que era uma utopia uma faculdade no interior, mas ela deu certo. Na minha formatura em 1961 o orador foi o Fernando de Azevedo, o principal livro dele é "Educação em dois mundos". Ele disse que entendia o receio daqueles que não acreditavam no ensino da Fafi no início, mas que essa dificuldade não existia, pois os professores que o Jânio contratou eram os melhores. Primeiro vieram três professores estrangeiros: o Antônio Pinto de Carvalho, o Edoardo Querin e o Arnold Von Brugenhagen, este último alemão com uma visão de mundo muito positiva.

Esses professores vieram para Rio Preto trazendo muitas novidades. Nesse período o prefeito era o Dr. Andaló e a cidade passava por um desenvolvimento tremendo. Nesse primeiro momento, a faculdade, ainda municipal, esses professores foram acolhidos, a elite ficou entusiasmada por ter com quem conversar, afinal eram estrangeiros, algumas vezes o salário deles atrasava, mas sempre tinha alguém para ajudar, como o Quincas Pereira, por exemplo.

Com a estadualização a proposta inicial da Faculdade foi mudando: era necessário com que se conversasse a respeito de tudo, se refletisse sobre todos os problemas e que se colocassem as diversas faces deles, isso foi gerando novas atitudes na geração jovem, nos alunos. Não havia mais dogmas, podíamos discutir e encontrar nossa própria resposta, muitas vezes ela coincidia com respostas já estabelecidas, outras não. Os pais perceberam que seus filhos já não eram tão religiosos, falavam sobre coisas que antes não eram abordadas... isso foi incomodando. Os professores também tinham suas opiniões políticas e como qualquer cidadão comum tinham o direito de debatê-las fora da Faculdade, as discussões aço teciam fora da sala de aula também. Isso foi criando um mal estar e de repente a sociedade, à qual pertence a elite, percebeu que aqueles professores iam criar problemas para ela. Os questionamentos sobre organizações, entidades, voto incomodava muito. Além disso, a Faculdade tinha problemas internos, um deles era a idéia de departamento, representatividade, os professores da Letras e da Pedagogia eram mais abertos, os da História Natural não eram vistos com agrado. 
Os alunos da Letras e da Pedagogia tinham representantes dentro do departamento e tínhamos o direito de modificar algumas coisas indo até contra professores, que acatavam a nossa decisão. Havia também uma interdisciplinaridade entre nós, diálogo. O pessoal da História Natural nunca aceitou isso e a distância entre os departamentos e as pessoas que os compunham foi aumentando. Essa falta de convivência resultou em falta de harmonia. Lembro que quando se deu o afastamento do Grisi foi feito um documento e os professores assinaram, alguns deles desistiram depois de assinar, foram à câmara municipal, o Celso Abade Mourão foi um deles, ficou com muita raiva, ódio, acabou assinando um ofício de apoio ao Grisi e a crise foi crescendo. Finalmente o Grisi saiu e o Dr. João Dias da Silveira, que já era diretor em São Carlos, acumulou cargos. Ele era um pesquisador, dialogava com todos os departamentos, não impunha nada, alguns professores da Naturais não gostaram nada e a crise foi crescendo, crescendo e culminou com o Golpe de 1964.

Comecei a trabalhar na Faculdade em 1962, em 63 já era assistente do Casemiro Reis Filho e em 64 veio a bomba, a Revolução entre aspas.

Nós nem imaginávamos que eles, os militares, pudessem olhar para Rio Preto. Foi um choque perceber que a Faculdade era visada, que nossos professores estavam sendo presos. Até hoje não consigo ver com clareza o motivo deles voltarem tão rapidamente o olhar para Rio Preto...tudo bem, tinha o GRUTA, o Heimer com o Centro Popular de Cultura, a AP...

Eram grupos que estavam voltados para as questões sociais, não havia partidos políticos, havia até padres envolvidos, como o Jarbas, que é padre aqui agora e que era da JUC, o Gavino, o Zé Maria, todos padres...não havia propriamente uma liderança, todos nós participávamos. Era o espírito da época. Agora, pode ser que tenha havido em alguns uma visão de socialismo, mas não era, necessariamente um socialismo marxista, afinal existe o socialismo cristão. 
Até hoje não entendo esse medo da sociedade, dos militares... talvez fossem as idéias, o manifesto dos professores em defesa da escola pública...esse manifesto foi muito divulgado e talvez tenha chamado a atenção.

Não sei, pode ser que alguém da elite ou professores descontentes possam ter procurado alguém, mas não sei, houve até uma disputa entre um professor que depois veio a ser nosso diretor, o Antonio Bento Coelho, ele não era professor na Faculdade na época, mas pegou um gancho num artigo do Casemiro e começou um debate, ou melhor, uma briga. Eu já era assistente do Casemiro e disse a ele que não gostava dessas brigas pelo jornal. Além do mais, era uma discussão absurda, como o Casemiro podia ser comunista se ele era espírita "roxo". Eu sou católica e ele sempre me respeitou... uma discussão sem sentido, ele era um homem voltado para o ser humano e pra Deus. As pessoas nem sabiam o que era comunismo.

É uma pena que a elite de Rio Preto não pensasse no espírito da Universidade, que é a unidade na diversidade. Ninguém pensou: - Vamos escutar a todos, vamos ver todas as doutrinas... poucas pessoas pensaram assim, e essa elite era culta, esperava-se outra posição.

Enfim, não entendo o que poderia ter provocado esse olhar tão agressivo de desconfiança para Rio Preto. As meninas do nosso grupo eram taxadas de melancia, verdes por fora e vermelhas por dentro. Nosso comportamento ao freqüentar um barzinho que depois virou uma casa de chá chamada "Luar de Agosto", por causa do filme do Marlon Brando, os agredia... achávamos que ficar andando de lá pra cá no footing já era um negócio ultrapassado. Nossos hábitos foram mudando e isso foi visto com muita reserva, afinal estávamos quebrando uma coisa que já estava estruturada... aquela vidinha pacata estava se alterando... era uma sociedade provinciana, cristalizada. Acho que quando criaram a Faculdade não pensaram onde ela ia chegar.

Com certeza, as novidades foram criando a desconfiança. A eleita se perguntava: “O que será que trouxemos para dentro de casa?” e aí não tinha mais retorno. 
Víamos a necessidade de alfabetizar os adultos para que eles tivessem a possibilidade de melhorar de vida. Formamos alguns núcleos, eu a Cidinha, a Lederci, enfim, as meninas da Pedagogia junto com a Professora Maria Edith di Giorgi.. por causa disso acabaram na cadeia em celas junto com as prostitutas. Fui até falar com o bispo auxiliar, pedir ajuda, mas o delegado se recusou a recebê-lo. Que idéia mais espetafurdia, achar que alfabetização de adultos tinha a ver como o comunismo.

Bem, prenderam todo mundo, depois vieram buscar os professores assistentes para dar depoimento, como eu não me encontrava na Faculdade naquela hora fui até a delegacia depois. Aguardei das 4 até as $7 \mathrm{~h}$ para ser atendida junto com outros professores assistentes.

Quando fui ser interrogada, o delegado fazia a pergunta e ele mesmo dava a resposta. Os assistentes não ficaram presos, mas os professores sim, alguns nem voltaram como o Cantoni, o Penteado e o Cunha, este último era da História Natural, o único que era diferente dos outros. Ele era carioca, declarava ser do partido comunista... no fim todos os professores que foram presos perderam o emprego. Veio um interventor.

Esse interventor, o Dr. José de Castro Duarte era juiz. Ele era durão com os alunos, mas gentil com a gente. Foram contratando novos professores, a maioria da cidade, foi o caso do Coelho, as coisas foram se distanciando. O Coelho fez carreira na Universidade e depois chegou a diretor em Assis. Ele tem capacidade intelectual boa, mas havia ficado magoado porque ao invés de darem as aulas para ele no início, chamaram o Norman Potter, uma americano alto, olhos claros, tipo 007, todo misterioso. A maioria dos professores que assumiu depois do Golpe não tinha curso universitário, então quando eles entravam em sala eram olhados com muita desconfiança, era um conflito com cada um que entrava. Alguns alunos não tinham problemas com os novos. Tivemos problemas com comportamento de alunos e de professores. 
Foi bastante difícil, achei que não ia agüentar, tanto a parte psicológica quanto a de trabalho. O número de turmas que eu tinha que cuidar dobrou. O Casemiro dizia que eu ficasse calma, que daí a dois anos tudo teria passado... Não foi bem assim.

A coisa mais dramática foi a perda dos nossos professores, nós os conhecíamos a fundo, sabíamos do que eles eram capazes, não ficavam fazendo política em sala de aula...foi uma perseguição, sim, perseguição. Às vezes eu pensava que teria sido melhor se eu tivesse ido embora com eles, mas pensava que já que havia ficado era aconselhável tocar as coisas da melhor maneira possível para quando eles voltassem. Mas, eles não voltaram.

Foi uma experiência sofrida, mas aprendi muitas coisas, o ideal da educação e consegui passar isso para os meus alunos.

Uma pena que a educação hoje esteja desse jeito... foi decaindo...decaindo...as turmas na faculdade cada vez mais apáticas, alguns alunos ainda bons e era por esses que os professores eram estimulados... e a coisa continuou caindo numa queda cada vez maior.

Acho que ainda há possibilidade de melhora, de sair do buraco, existem profissionais sérios, comprometidos com a educação e as coisas estão mais fáceis, os tabus vão sendo derrubados.

Escrevi um boletim, o Sapere Audi sobre a Faculdade e fiz várias entrevistas que você pode usar. Não consegui falar com o Mauricio Tragtemberg pois ele não voltou a Rio Preto. O Michel Lövy quase nem chegou a vir e foi embora para a França antes do Golpe.

Bem, acho que no final, perdemos. Perdemos aqueles professores maravilhosos e hoje a universidade é mais quantitativa que qualitativa. 


\section{GRIGOR VARTANIAN}

Grigor Vartanian, hoje professor, recebeu-me em sua casa junto com a esposa. A sala era espaçosa, o calor intenso. A sala onde se deu a entrevista tinha sofás bastante confortáveis. A conversa não foi longa e bastante objetiva.

Foi um trauma ter sido preso. Depois disso fiquei com a boca cerrada, não falava nunca o que eu pensava, tinha um medo danado de me expressar, de me expor...

Sou o Grigor Vartanian. Fui muito tempo professor da Fafi, isto é, Unesp. Comecei lá como aluno, passei no vestibular em dezembro de 1962, as aulas começaram em março de 1964 e me formei em 1966. Logo que entrei na Faculdade comecei a participar do diretório acadêmico da Filosofia, nas assembléias comecei a pedir a palavra...falava...fui me liberando...havia um auditório e aquilo me entusiasmava demais...falava...falava... eu era o "pêssego" dos jovens daquela época...era o exagero político, pensava que podíamos mudar o modelo social, dar oportunidades para as classes desprivilegiadas da sociedade...isso era o modismo da minha época do final do colegial ao início da faculdade...eu tinha essa inclinação para o discurso, além disso queria me tornar agradável para o grupo, que era considerado evoluído.

$\mathrm{Eu}$ gostava muito dos professores, principalmente daqueles que vieram da Europa, esses gozavam da minha apreciação total, havia o Prof. Arnold, alemão, o Antonio Bellini, italiano... sabe esses professores estrangeiros eram mais conservadores, mais adequados a cidade de São José do Rio Preto, na época, bastante provinciana que costumava olhar os professores e alunos da Fafi com muita desconfiança. Cansei de ouvir o seguinte conselho: “Olha você vai estudar na Fafi, mas não se envolva com as pessoas de lá, lá o negócio é perigoso". Esse se aplicava, 
não aos europeus, mas aos professores egressos da USP, que se trajavam de um modo diferente eram mais "inconvenientes" eram menos formais, porém percebi que lá tudo era coletividade, eu não era um alienígena, fazia parte de um todo.

Havia o professor Orestes Nigro que se destacava pela popularidade e isso me influenciou, afinal eu era das Ciências Naturais, onde os professores eram mais conservadores, adequados a mentalidade da cidade, como por exemplo o professor Luiz Dino Vizotto, muito querido, muito amigo, protetor dos alunos, o Celso Abade Mourão que era chefe de departamento.

Bem, houve uma eleição para o diretório acadêmico no meu segundo semestre e resolveram me colocar numa chapa como tesoureiro, o Pedro Bonilha era o candidato a presidente. Não me lembro com muita precisão porque eu não dava muita atenção à isso, mas fomos eleitos, assumimos o diretório no final do mandato da turma do Murilo Farinazzo... o Joacir Badaró também foi presidente do diretório, os dois eram líderes renomados. Eu gostava muito dos professores da Pedagogia, da Letras... do Professor Cantoni, do Fávio di Girogi, ele era muito distraído, lia jornal sentado na calçada...eu costumava fugir das aulas de Biologia para assistir a aula dele, ele falava dos grandes filósofos da Grécia, era fluente, tinha voz poderosa, assim como o Professor Anoar Aiex... eu ficava bebendo a sabedoria deles. Eu era muito jovem, estava apaixonado por eles, eram meus ídolos, trouxeram até o Juca de Oliveira para ajudar a montar um grupo de teatro... ele tinha um entusiasmo...uma vontade de mover as águas...chegamos até a ir ver uma peça no Teatro de Arena.

Em novembro de 1963 o presidente Kennedy foi morto. Fiquei em choque. Lembro que o Professor Prósperi me pegou pelo braço e disse:- “Grigor, te pró́bo de abrir a boca, de ir nessas assembléias, você é muito impulsivo e tenho certeza que essa morte é sinal que virá uma revolução de direita na América do Sul, principalmente no nosso país... os líderes de esquerda vão ser implacavelmente perseguidos... não quero você metido nisso, não quero ninguém apontando para você e dizendo que você era comunista."Obedeci, em parte. Diminui a freqüência nas assembléias. 
Então aconteceu a Revolução de 31 de março. Pouco tempo antes, em janeiro de 1964, eu havia ido numa reunião da UEE (União Estadual dos Estudantes) na região de Campinas e em meados de fevereiro fui à São Paulo num encontro na Praça da Sé e quando estávamos chegando lá encontramos a polícia. Houve tiros, confusão e o grupinho de Rio Preto de dispersou. Voltamos para Rio Preto, demoramos 2 ou 3 dias para chegar, ficamos com receio...aí veio a Revolução e ficamos com receio de falar sobre esses acontecimentos dentro da Universidade, ficou um clima meio de pânico lá. Alguns dias depois um policial civil bateu na minha porta... eu não estava em casa, então no outro dia fui falar com o delegado, o Doutor Mariano. Perguntei o porquê da ida do policial à minha casa, não havia matado ninguém. O delegado disse que era eu um jovem líder, instigador de jovens. Fui liberado, mas no outro dia a polícia veio com uma viatura e fui preso. Não fui nem para o presídio, fiquei na cadeia mesmo e lá estava também o Pedro Bonilha. Ficamos presos na delegacia cerca de uma semana, de lá nos transferiram para a cadeia perto do cemitério. Só tinha preso político e ficaram ameaçando de nos mandar para São Paulo.

Acho que a primeira faculdade que sofreu intervenção dos militares tenha sido a de Rio Preto porque a cidade era muito conservadora, provinciana e aqueles professores que vieram da USP foram absorvidos por ela, e não os da cidade, os professores de São Paulo eram considerados estrangeiros, houve sempre uma rixa entre eles e o professor Daud Jorge Simão, ele considerava os uspianos como um corpo estranho que tinha que ser extirpado da faculdade, acho que ele era movido por um certo revanchismo por ter sido preterido na faculdade. "“Ele era extremado, mas amabilíssimo, foi meu professor no colegial, costumava falar algumas frases bonitas como:-" Não encoste sua cabeça no travesseiro sem ter construído alguma coisa hoje". Eu anotava essas frases, devia ter umas oitenta. Mas o ego dele era um problema e ter sido preterido era complicado para ele. Não havia comunistas na faculdade, só queriam que o povo pudesse participar do poder... na época o rótulo de comunista era intolerável...eu tinha uma formação religiosa sólida e me perguntava, apenas, se esse mundo tão bom não deveria ser mais justo. 
Esses professores abriam os horizontes para a gente, mas não acho que depois deles a faculdade tenha perdido a qualidade, e estou falando isso do alto dos meus 65 anos. Dentre os próprios professores havia aqueles que não estavam tão preocupados com o social. O Heimer era um que tinha uma visão do social, era humanitário, solidário... era uma visão teológica, dava cursos para operários da construção civil, estava organizando um sindicato... até ajudei a montar o material desse curso... era trabalho voluntário que eu fazia quando não estava lecionando para minha sobrevivência.

Foi um trauma ter sido preso. Depois disso fiquei com a boca cerrada, não falava nunca o que eu pensava, tinha um medo danado de me expressar, de me expor... fico admirado com o direito das pessoas falarem hoje, nós falávamos $10 \%$ disso e olha o que aconteceu... essas pessoas de hoje seriam degoladas! Se eu voltasse no tempo, acho que com a experiência que tenho hoje... vendo como você tem pouca gerência sobre as coisas que acontecem na sua vida... acho que resolveria as coisas sem causar nenhum conflito.

Tenho três filhos e eles são mais calmos, mais conservadores, ensinei a eles que não conseguimos mudar a gente mesmo, que dirá o mundo? Se você não puder falar alguma coisa é melhor não falar nada.

O delegado sempre me perguntava onde eu tinha aprendido as coisas que falava e eu respondia que tinha sido com a Bíblia que meu pai lia toda noite, e tinha. Encontrei gente como o Casemiro Reis Filho que era maravilhoso e pregava aquilo que aprendi em casa... Sabe, esses professores da USP também tinham o ego inflamado, eles sabiam tudo, os outros eram ignorantes, até o prefeito... imagina a dimensão...era uma USP em São José do Rio Preto. Acho que eles não estavam preparados para uma USP caipira e a cidade não estava preparada para eles, chamavam muito a atenção e daí surgiu o conflito. Os professores não eram comunistas, eles queriam justiça social, mas o que havia não era injustiça social, era incompetência social do Estado brasileiro e isso continua, mesmo com um presidente que deveria ser uma liderança social, a corrupção é enorme, isto é um 
pântano, temos que pensar em outro modelo, duríssimo como era no Iraque e olhe que meu pai foi fugitivo do massacre turco. Admirava muito o Alberto Fujimori, expresidente do Peru, que as 6h30 da manhã estava numa favela vendo a construção de casa populares... e deu no que deu. Há muita gente corrupta no Brasil... imagina que eu ia dar um curso na Universidade Federal de Teresina e me mandaram 12 passagens. Usei 9 e tentei devolver as outras e não consegui. O Ministério da Educação e Cultura disse que não podia aceitar porque a verba já tinha sido gasta, então viajei com minha mulher...veja, fui induzido a cometer uma fraude.

Hoje em dia só leciono como voluntário, agora que estou aposentado da UNESP, onde fui professor adjunto, faço coisas que gostaria de ter feito e não tive tempo quando estava na ativa. A falta de educação, em todos os sentidos do termo, nos dias atuais é enorme...ninguém segue as leis de trânsito, os alunos não respeitam professor, jogam lixo na rua, acho que isso é uma coisa nossa, do brasileiro.

Sabe, embora eu veja como está a educação hoje, ainda tenho esperança. Os professores precisam ter apoio, contar com tecnologia, se bem que a tecnologia hoje está banalizada, o povo usa celular para falar bobagens... se você não tem nada de importante para falar é melhor calar a boca, meditar um pouco sobre a existência, sobre a inevitabilidade da morte...acho que a humanidade tem um caminho muito difícil pela frente... há uma degradação de valores, da moral coletiva, da ética, todo mundo muito hedonista...é um culto ao prazer extremado sem fazer nenhum sacrifício. Sabe, uma vez formei um grupo de 40 pessoas, o objetivo era o autoconhecimento e a solidariedade, visitávamos hospitais aqui em Rio Preto... fiz um teste com eles, pegávamos todas as contas e dinheiro de cada um e pagávamos tudo junto... eles não agüentaram o tranco... o leão rugiu dentro deles e eles não agüentaram... o ser humano está perdendo o domínio de si, está se entregando aos instintos primitivos... e olhe o que está acontecendo. 


\section{MARIA DE LOURDES CÁPUA}

Conversei com a Profa. Maria de Lourdes na sede do Sindicato dos Supervisores de Ensino do Estado de São Paulo onde ela trabalha após sua aposentadoria. De todos os colaboradores ela foi a mais emotiva. Chorou muito, manteve longos silêncios e percebi que ainda existe uma mágoa e uma sensação de impotência muito grandes nela. Ela sugeriu que eu organizasse uma reunião com todas as pessoas que entrevistei para este trabalho. Diz que tem saudade.

Sabe, ficar na cadeia uma semana não foi o mais difícil, mas na hora em que saí e voltei para faculdade... desculpe, choro ainda quando me lembro... quando voltei para a faculdade meus professores queridos não estavam mais lá...

Nasci em Lins, interior de São Paulo, mas fui criada em Poloni, uma cidade tão pequena que, costumo brincar, nem existe no mapa. Fiz o curso primário lá, e era só o que tínhamos, então para cursar o ginásio e a escola normal tive que viajar para Monte Aprazível, outra cidade próxima, durante anos. Na verdade, o último ano da escola normal fiz em São José do Rio Preto. Logo que sai do segundo grau entrei na faculdade. Somos cinco irmãos e três deles são professores, não me casei e hoje tenho até sobrinho neto. Sempre que possível auxilio meus sobrinhos com os estudos

O ingresso na Fafi foi uma coisa maravilhosa e provocou em mim um grande amor. Era uma faculdade modelo, os professores eram da USP, tinham um jeito de ensinar... muito, muito bom, principalmente o de Sociologia, Wilson Cantoni... os de Filosofia, Aiex e Aloisio Reis de Andrade, também eram especiais... me apaixonei por essas disciplinas por causa dos professores que tive... só o final do curso não teve nada de glorioso... fui parar na cadeia. 
Sabe, ficar na cadeia uma semana não foi o mais difícil, mas na hora em que saí e voltei para faculdade... desculpe, choro ainda quando me lembro... quando voltei para a faculdade meus professores queridos não estavam mais lá, muitos colegas tinham ido embora... se isso não tivesse acontecido creio que teria feito carreira universitária, mas depois do que presenciei em Rio Preto... não... nunca.

Foi uma espécie de desilusão, uma coisa tão boa ser destruída... o Gruta que trabalhava com cultura, o Heimer, que fundou a AP, com a alfabetização de adultos...fiz até o treinamento, e foi por causa desse movimento que viramos vítimas. Fazíamos o trabalho numa escola no bairro Esplanada, a noite, porém outros professores como o Newton Ramos de Oliveira trabalhavam em outros locais... foi um trabalho muito bonito e isso me emociona muito... são tantas lembranças.

Bem, depois do Golpe voltei para a faculdade e aí, a única coisa que eu queria era terminar o curso o mais rápido possível, doía ter aulas com o Coelho, um professor medíocre, depois de ter tido grandes mestres. Assim que me formei vim para São Paulo lecionar, primeiro lecionei História, embora não tivesse feito faculdade de História, na minha grade havia tantas horas de História que isso me habilitou. Em São Paulo acabei prestando concurso para diretora de escola e depois virei supervisora, e é isso que faço até hoje, embora esteja aposentada, atuo no sindicato. Fazemos um jornal, pelo menos um encontro anual, chamamos pessoas para dar palestras... acho que continuo fazendo o mesmo que fazia em Rio Preto no início da Faculdade, porém agora não corro o risco de ser presa.

Depois do Golpe mantive contato com o Orestes, que ficou um tempo morando em Monte Aprazível e com o Aloizio que é casado com uma colega... As aulas da faculdade eram muito boas, os professores exigiam a participação da gente o tempo todo, devo esclarecer que nem todos professores eram assim, o de Matemática era terrível. Ele começava a aula dizendo que não íamos aprender nada... agora os outros...era um entusiasmo... a gente confiava neles e vice-versa. Eram bem jovens. Alguns pais não gostavam deles, mas os meus, que os conheceram quando fizemos 
um evento de arte em Poloni, gostaram muito. Fazíamos eventos em cidades da região.

Quando fui presa, meu pai que era político e tinha seus contatos não me deixou ficar muito tempo na cadeia. Repito, não fiquei traumatizada por ter sido presa, meu trauma foi ver que nós tínhamos um negócio tão bem feito para mudar o mundo radicalmente, um modelo tão especial, não ter dado certo. $\mathrm{O}$ diretor que assumiu a faculdade, um tal de José Duarte conhecido como "carrasco da Ilha Grande", ajudou a repressão, ajudou entregar todo mundo, nem pensou nos alunos. Horas depois do Golpe os interventores estavam lá em Rio Preto, não tinha militar, mas quem estava lá, estava a mando dos militares. A própria cidade não nos apoiou, achavam bom, para eles nós sempre fomos alienígenas. Teve uma colega, a Yvone Morão, que denunciava todo mundo, o Professor Daud... essas pessoas nem me conheciam direito e me denunciaram... denunciaram professores... eles queriam o lugar deles na faculdade... tanto que depois o Daud virou professor e a Yvone também... acho que se aposentou na UNESP. Era pura inveja! Além da inveja, tinha o delegado Tácito de Pinheiro Machado, que queria fazer carreira... até entendo o lado do Daud e do Tácito, mas a Yvone... uma aluna, que teve professores como aqueles da USP, ser reacionária... não entendo.

O nome que dou para aquele acontecimento de 64 é Golpe. Foi um Golpe mesmo... diziam que o país estava sendo invadido por comunistas, uma grande desculpa, o que eles queriam era tomar o poder... fui muito prejudicada, quando prestei o concurso para diretora minha nomeação não saía... é que meu nome estava no DEOPS, tive que entrar na justiça e só pude assumir dois anos depois.

Se não tivesse havido o Golpe a Faculdade hoje seria uma coisa muito desenvolvida, acho que eu até estaria dando aula lá. Acho que foi por causa da Faculdade de Rio Preto que resolveram transformar as faculdades do interior em UNESP... com a UNESP foi possível mudar o grosso do corpo docente. Acho que tive muita sorte de estudar na Faculdade, embora depois da intervenção... 
Os professores eram tão unidos aos alunos que conseguimos mandar o Rafael Grisi, que segundo consta desviava verbas, embora.

Sabe, o que mais me machuca é ver a educação indo mal, muito mal. Não consigo enxergar uma solução a curto prazo, nossos governos não estão interessados em investir na educação...o próprio Serra, que era uma pessoa que eu admirava, olha o que ele faz, nada, não faz nada pelo professor e ainda diz que a educação está ruim, não pelo salário do professor, mas por incompetência dos mesmos... a culpa do aluno não aprender é só do professor, o professor tem que ser castigado se ele não aprender... não sei se rio ou se choro.

Sem exagero, hoje em dia só vai ser professor quem não tem habilidade para ser caixa de supermercado. Isso poderia ser resolvido se houvesse uma prova séria para verificar o conhecimento do professor... aí as coisas mudariam. Só que para fazer isso tem que ter vontade política... você corre o risco de ter professores bons que vão ensinar os alunos a pensar... foi o que aconteceu em Rio Preto, a gente pensava, achava que o Brasil ia dar certo... não existe arrependimento sobre o que fiz em Rio Preto, na verdade só me arrependo de não ter feito mais. Achava e continuo achando o conhecimento fundamental e fico feliz por ter brigado pelos meus sonhos. 


\section{EDSON GUIDUCCI}

Entrevistei o Edson em Monte Aprazível, a cidade onde ele mora hoje e onde fui criada. Foi difícil conseguir encontrá-lo. Devo sua localização á uma colega dos tempos de adolescência, Vânia Leal. Ele está casado com uma professora de Português, com a qual tive aulas em meados dos anos 1970, Dna. Neli. Foi muito bom reencontrá-la . A entrevista foi objetiva. Edson mostra um desencanto grande com a educação.

Sabe, o projeto pedagógico da turma de humanas era fantástico, tinham um grande projeto educacional, tanto que foi a primeira faculdade que sofreu intervenção em 64, no Brasil...

Meu nome é Edson Guiducci. Eu era funcionário da Fafi, mais tarde prestei vestibular e fui cursar História Natural. Logo no início me integrei com o grupo do Orestes, o Gruta... sabe eu cantava moda de viola, gostava de poesia e o Gruta era um grupo artístico... nem sei o que estava fazendo num curso de Ciências...passei a participar muito do grupo e o Orestes era nosso grande guru, um verdadeiro líder.

Nossa preocupação maior era com aquele período político, na verdade não tínhamos preocupação de fazer sucesso... afinal muitos já trabalhavam, inclusive eu... embora alguns só estudassem. Fazíamos todo tipo de arte, cheguei a escrever, inclusive, algumas peças de teatro, versos... fazíamos grandes apresentações, tínhamos até um grupo de jogral. Fazíamos apresentação pelo interior todo: na Faculdades de Araraquara, Rio Claro, São Carlos... vivíamos nesse mundo e acreditávamos que era uma coisa boa. Publicamos até um livro de poesias ode escrevi uma coisa que acho bonita até hoje: O gigante de espuma...era uma analogia ao Brasil.

Sabe, posso dizer que éramos uma esquerda festiva, um grupinho ingênuo, ninguém sabia muita coisa... claro que havíamos lido um coisinha ou outra do Che Guevara, dos guerrilheiros, mas ninguém tinha revólver, garrucha, não tínhamos nada, éramos um grupinho idealista, boboca, que achava que com aquilo, o teatro, as 
artes, melhoraria alguma coisa. Aí veio a revolução... 1964... Eu lecionava em Ibirá. As 5 ou 6 horas da tarde do dia $1^{\circ}$. de abril fui preso. Fui detido com o Orestes e com a turma toda. Fiquei preso uns 20 e tantos dias... não fui torturado, não aconteceu coisa mais grave... houve um período de tensão e aí sai da cadeia. Acabei me formando...fui pra Brasília, mas minha ficha corrida no DEOPS ficou. Eu nem era comunista, não era de partido nenhum... a atividade cultural era nossa bandeira.

Um dia, por volta de 1969, 1970, eu dava aulas na UNB havia 4 anos, era concursado... fui exonerado... soube imediatamente porque... haviam achado meu dossiê... mas eu lecionava em outras escola, já era casado...não me prejudicou muito... Agora a Revolução foi uma desgraça, fez uma desgraça.

Sabe, o projeto pedagógico da turma de humanas era fantástico, tinham um grande projeto educacional, tanto que foi a primeira faculdade que sofreu intervenção em 64, no Brasil...já nas ciências naturais...era assim... eu não senti a força da Faculdade...hoje sei que foi uma grande escola, todos que saíram de lá se deram bem, se firmaram como profissionais...foi desse estudo que veio o meu futuro.

Sabe lembro do meu mestre de Didática, acho que o nome era Arruda Penteado...ele dizia que Rio Preto era a Méca das bruxas, foi uma cidade que delatou todo mundo, a sociedade não aceitava aquela dose de modernidade que estava se estabelecendo ali com a faculdade. Era gente de fora... olha eu tinha colegas da USP, que quando chegavam ali para pesquisa e conversavam com a gente... ficavam bobos... diziam: - Vocês já estão vendo isso? Nós ainda não vimos! Era uma faculdade que formava, não só conteúdo, mas formava a mentalidade científica... havia seriedade sabe? E era assim em todos os cursos. Havia grandes profissionais... tínhamos certeza de que íamos ser grandes... de repente... caiu tudo por terra. Acho que esses professores tinham um grande projeto... até hoje quando encontro um colega daqueles tempos ouço: -Ah que saudade! Foi uma coisa que marcou todo mundo.

Nós tínhamos formação política... acho que ia além da política, era ideológica... era uma vontade que o Brasil desse certo, que progredisse.. e a revolução podou todo mundo.

A educação é uma decepção... o aluno hoje é um estranho... falei para a Neli, 
minha mulher, que embora tenha capacidade, era hora de me aposentar.. não tenho mais acesso ao aluno... a escola está indo do jeito que Deus dará, vejo isso com muita tristeza, leio jornais, não se cobra nada, não existe um plano definido... sou muito pessimista em relação ao futuro que nos espera... não vamos ter mais bons profissionais, nem de nível médio capazes de movimentar uma máquina, de produzir qualquer coisa... simplesmente virou uma bandalheira...isso é o que tenho visto em sala de aula.

Hoje você está dando aula e o aluno está mandando torpedo para os outros, você não pode fazer nada, se fizer a direção chama sua atenção... alunos agridem professores e a diretora não faz nada... estou totalmente descrente... sempre dei aulas em escolas boas... na UNB, no Colégio Objetivo de Brasília, no Seta, aqui em Rio Preto, escolas de alto nível, mas está tudo igual... um caos.

O que fiz em 64 e antes foi consciente, não ficou arrependimento. Fiz acreditando em uma verdade... era inocente...idealista, não tenho ressentimento, apenas lamento pelo que a gente passou.

Criei meus quatro filhos, todos formados. Lembro daquele período como uma coisa obscura, triste, um atraso para o país, um enorme atraso. Veja, hoje o Congresso está lá, instalado, um monte de medidas provisórias, discutindo partidos, havendo recessos... como se o país pudesse esperar esse tempo e essas discussões. É uma democracia sem cabeças pensantes... eu sempre fui de esquerda, do PT e hoje vejo o Lula... fazendo acordos, que partido governa o Brasil hoje? O PT, o PMDB? O PSDB?... É uma miscelânea e não vão largar o poder tão cedo... estamos na mão dessa camarilha... então só me resta aguardar o que vem por aí... esse populismo terrível...

Lamento por esses jovens... se eles não estudarem muito e bem... sabe, fico o dia inteiro lendo, não faço mais nada. Acredito que só quem estiver preparado, for um intelectual vai poder vencer com dignidade, talvez modificar isso tudo aqui, porém não estou enxergando como, não vejo o fio da meada.

Falo para a Neli, essa pessoa maravilhosa que me esperou 18 anos... namoramos na juventude, fui embora, casei com outra, tive 4 filhos e ela me esperou... agora estamos juntos e hoje sou um cara feliz... tive pai pedreiro, minha mãe era uma coitadinha, analfabeta e hoje estou aqui, tenho 70 anos e estou feliz. 


\section{LUIZ DINO VIZOTTO}

O Professor Vizotto me recebeu, gentilmente, em sua casa no dia de seu aniversário. É uma casa espaçosa, bem decorada e confortável. Sua esposa, uma mulher bonita, elegante, serviu suco e a conversa foi longa, interrompida várias vezes por telefonemas de felicitações e pelos seus cachorros.

\section{Quando começaram os movimentos em 1962, 63, 64... foi o fim...}

Vim para Rio Preto em 1956, meu nome é Luiz Dino Vizotto. A Faculdade de Rio Preto estava, ainda, num período de estruturação, era uma proposta nova de alguns políticos da cidade. O primeiro professor a chegar foi um português, o Antonio Pinto de Carvalho, ele ajudou a organizar tudo. A medida que a estruturação ia tomando forma outros professores foram chegando, o Wilson Cantoni, o Casemiro dos Reis Filho... , mas a maioria era de professores da cidade que davam aulas no Ensino Médio e foram assumindo as cadeiras desde 1955. Não vim logo do início porque a cadeira disponível não era aquilo que eu fazia... eu era biólogo... gostava de lidar com bichos, a Zoologia. Quando foi possível atuar na minha área, resolvi aceitar.

Naquela época professor ganhava bem, eu tinha duas cadeiras em Araçatuba, posso dizer que ganhava o mesmo que um juiz. Embora fosse professor do Ensino Médio ganhava o suficiente para freqüentar clubes, éramos solteiros... depois veio a degradação... uma pena! Hoje professores do Ensino Médio ganham menos que soldados...um absurdo... bem, continuando... viemos eu, o Aloizio Reis de Andrade, o Cantoni... O primeiro dia de aula foi em $1^{\circ}$. de Abril de 1957... acho que tenho uma fotografia do corpo docente...saiu nos jornais. Havia também o Norman Potter, de Inglês, o João Jorge da Cunha de mineralogia... quando o Norman saiu em 1964 foi para a Alemanha e depois para os estados Unidos, para o Texas. Almoçávamos 
juntos... depois por volta de 1980, já Unesp, a anistia permitiu que o Norman voltasse, mas ele já voltou combalido, doente e acabou morrendo. Havia também o Rodolfo Azzi que era professor de Psicologia... nunca mais ouvi falar dele... tem um irmão dele que parece que é da Letras na USP, não sei se ainda é, mas o Rodolfo... não sei se faleceu.

Por volta dos anos 1960 veio a Sara Rottemberg que foi um elemento muito importante na Pedagogia... acho que ela não fazia parte do contingente que foi cassado, acho que em 1976 ela estava em Marília...ou seria Araraquara? Ela tem vindo para cá nas comemorações de final de ano... há algum tempo ela queria meu holerite para ver se conseguia uma aposentadoria maior...

Quando vim para cá não existia essa coisa de pós-graduação...funcionava assim: você fazia um trabalho de pesquisa inteirinho, anexava fotografias, fazia toda produção e levava para a USP para arranjar um orientador, conversava com um professor, ele lia seu trabalho, aceitava te orientar e daí dois meses você defendia na Congregação. Fazíamos cópias no mimeógrafo e defendíamos. Hoje é diferente, você cursa disciplinas para os créditos correspondentes, faz mestrado antes de ir para o doutorado e já vai com uma base boa e as leis acabam te favorecendo, quem tem só mestrado não pode ser titular, naquela época íamos pra o doutorado direto e já éramos titulares, não precisava de currículo, de memorial, nada disso... no caso da Sara, ela não havia feito doutoramento... ela disse que não estava mais na Faculdade... aí o salário não poderia ser o mesmo, mas então entram os advogados, justiça... a Sara fez Direito e advoga até hoje.

Bem, finalmente a Faculdade se estruturou... por volta de 1960 fazíamos bailinhos, quando era aniversário de alguém íamos até a casa para a festa... bem houve um certo... na História Natural, com exceção do Cunha que era carioca e filiado ao PCdo B... naquela época ser... quer dizer quem era do PCdoB era meio... desculpa, não consigo falar isso sem rir, olha era uma certa coisa, mas eu me dava bem com o Cunha, ele era um sujeito ativo, participava de reuniões aqui, em Nova Granada, mas nós fizemos as mudanças na Faculdade que hoje é uma Universidade. 
Começamos no Instituto de Educação com seis salas, alugamos outro prédio onde hoje é a sorveteria Alaska, com biblioteca e mais salas de aulas... em 1958 estabeleci o biotério, tínhamos um quintal grande, fazíamos bailinhos com alunos, professores... era essa relação.

Quando começaram os movimentos em 1962, 63, 64... foi o fim... veja, eles trouxeram professores da Alemanha, o Heimer que acabou se envolvendo com movimentos da zona rural, ele era um bom professor, gostava dele, mas... foi exilado, a senhora me disse que ele está em Portugal...e eu achei que ele quisesse, como foi para a Alemanha... ele tinha um envolvimento muito grande com a igreja católica, fundo a Ação Popular, mas movimentos assim chocavam a comunidade local, eles achavam que a coisa estava extrapolando, então a pressão da comunidade foi grande também, nesse sentido.

Aí teve o Jânio e com o Goulart vieram os movimentos, veio problema de todos os lados, era problema na marinha, problema não sei onde, aquela coisa toda... e houve a implantação do Regime Militar... quem estava aqui nessa época era o professor João Dias que substituiu Grisi... houve uma briga entre o Grisi e esse grupo, eles não aceitavam mais o Grisi, não sei o que aconteceu, eles acabaram levando o Grisi para fora... na verdade ele sempre foi um sujeito esquisito... morreu também. Ele fazia umas coisas que o grupo não gostava... comprava livros no sebo e obrigava os professores assinarem uma lista com o nome daqueles livros como se fossem importantes para a biblioteca. Quem não assinasse estava fora, então assinávamos, antes que aconteça um mal pior vamos assinar.

Veio o Golpe Militar... nenhum professor foi preso, só um aluno que se chamava Grigor Vartaniam... era um menino extraordinário, estava na finalização do curso, íamos na cadeia visitá-lo...nenhum professor, que eu me lembre, foi preso. Talvez só o Orestes tenha ficado preso, não me lembro... até me lembro que havia um grupo de teatro... uma vez o Juca de Oliveira veio aqui fazer uma palestra sobre o envolvimento dos alunos com o teatro, fizeram até umas peças interessantes... mas durou pouco, não passou de 1962, o Orestes virou adepto dessa cultura, levava 
alguns alunos para todo lado...falavam de cinema cultural...não me lembro bem, era um movimento cultural, mas porque trabalhava com cultura, não era um movimento no sentido mais amplo. Agora quando você vive numa cidade, como você, como eu e aparece uma pessoa com uma cultura mais elevada em relação ao que existe na boca do sertão, como era chamado isso aqui, causa certo impacto e como a gente está envolvido com a comunidade, ela começa a te pressionar.

No momento em que se implanta a Ditadura troca-se a direção da Faculdade, vem o José de Castro Duarte, juiz, diretor do fórum...sabe...um mão de ferro. Então ele aproveita que a comunidade pressionava para tirar alguns elementos que eles julgavam....contrários à situação atual... bem ele monta um processo com o Doutor Tácito Pinheiro e o Dr. Mariano, que já faleceu...ele foi meu contemporâneo no Ginásio... fizeram todo aquele processo, aquela coisa...a gente falava, tinha que falar... então era aquela coisa, como na História Natural não tinha nenhum adepto de partido político, como tínhamos que dar um curso de 5.500 horas em 4 anos, não tínhamos tempo de nos envolver com movimentos... então houve certo estremecimento do pessoal da Pedagogia e da Letras com os professores da História Natural, e depois...todo homem nasce político, queira ou não...

Quando se estabelece o período militar...pega um, pega outro... O Cantoni, coitado, um intelectual, se exilou... foi embora assim...outros que ficaram... você sabe, o pessoal vai na sua casa, você fica numa situação...acaba tendo que falar o você sabe. Teve um que jogou uma mala de livros na represa, agora o Cantoni, nem esperou começar o tal processo, foi embora logo.

Tivemos o Luis Ferreira Martins, que era secretário da educação, fiquei como diretor então. Nesse período, minha mulher, que era da cadeira de Espanhol teve uns problemas, não tive dúvida, fiz uma reunião na congregação e acabei com o grupo que era contrário... veja, eu não estava defendendo minha mulher, e sim uma profissional... ganhei antipatia generalizada do grupo. O problema era que ela era do espanhol e tinha feito doutoramento em Literatura Portuguesa... toda vez que ela ia para Portugal, ou para USP para trabalhar com o material o Antonio Cândido era um 
problema. Depois que fiz o pronunciamento na Congregação, isso é até divertido, quase fui linchado, sofri meses.

O fato era que esses grupos se chocavam desde 1955, havia esse grupo que tinha uma ideologia que se chocava com a comunidade, e também com a gente da História Natural que não éramos políticos, com exceção do Cunha... mas eu me dava bem com todos eles... costumavam dizer que tinham um projeto pedagógico, não vi nada disso...Cantoni chegou a publicar um trabalho sobre a questão da representação de alunos, na verdade ela já existia, mas era um ou dois alunos por departamento, agora ter uma igualdade... bem nós da História Natural não éramos políticos... o Cantoni era o farol que guiava essa turma, depois veio o Golpe...uns fugiram, outros ficaram na miséria, foram vender sanduíches na rua, o Cunha foi para o Rio e morreu, o Aiex foi para os Estados Unidos... perdi o contato com ele completamente. Olha, por exemplo, a Yvone foi crucificada, era aluna, mulher de um deputado, foi contrária ao grupo... o depoimento dela foi muito incisivo. O Daud também era contrário a esse grupo, foi o criador da Faculdade, era muito radical, incisivo, acho que foi ele que trouxe a Yvone para a Faculdade. Sei que existe um calhamaço de depoimentos de professores...

Aposentei-me em 1985, fui representante da FAPESP, vivi os dois períodos dessa instituição, como Faculdade Isolada e como UNESP, acho que até misturei as coisas...

Se não tivesse acontecido o Golpe Militar...bem que tipo de regime o João Goulart teria implantado no Brasil? Seria o comunismo? Socialismo? Se valessem todos os projetos que estavam em andamento aqui, creio que essa Faculdade se projetaria no Brasil, teria inovação, seria diferente da USP que nunca gostou de nós, povo do interior, a UNICAMP é mais evoluída, a USP até tem setores mais evoluídos, mas tem outros que são conservadores. Agora como teria sido... hoje as coisas estão tão diferentes, ninguém mais se fala, ninguém visita ninguém... Nada. 


\section{CORONEL ANTONIO RIBEIRO DE GODÓI}

Entrevistei o Coronel Godói em sua chácara, perto de São José do Rio Preto. Quando cheguei havia uma mesa de café da manhã com várias opções de doces e salgados. O Coronel foi muito agradável e prestativo. Ficou emocionado quando falou da Profa. Sara Rottemberg.

O João Goulart ia dar um Golpe, olha o comício que ele fez na Central do Brasil, os militares só deram um contragolpe antes dele fazer besteira.

Meu nome é Coronel Antonio Godóy, tenho 86 anos, fui comandante da polícia militar aqui da região de Rio Preto. Passei para a reserva em 1962 e resolvi fazer faculdade. Entrei na FAFI, estava no terceiro ano quando houve a Revolução de 1964. O coronel que estava no cargo quando aconteceu isso era meu amigo, tinha muita consideração por mim e me respeitava muito.

Alguns dias antes do Golpe me chamaram na corporação. Entrei numa sala e lá estavam reunidos vários oficiais, o delegado regional e o coronel. Estavam justamente planejando... eu não diria um ataque...bem, entrarem na Faculdade e prenderem os alunos e professores, era sabido que nos últimos 3 ou 4 meses esses indivíduos haviam se entusiasmado com o Governo Goulart, começaram a fazer comícios, teatro, todos apoiando o caminho que o Goulart estava tomando, esse negócio de reforma agrária, diziam que alguns professores eram comunistas, não sei se eram ou não, mas as coisas estavam fervilhantes... alguns professores eram os mais entusiasmados, começaram a pregar a destruição da família, a revolta do sistema familiar, falavam sobre como as mulheres deveriam agir e vestir, havia algumas exageradas que começaram a usar vestidos curtos, mostrando a calcinha, sentavam 
na rua, fumavam charutos, agrediam a sociedade. O povo, em geral se revoltou, não queriam isso, não estavam acostumados.

Houve exagero por parte dos alunos, incentivados por professores que pregavam a revolta dos filhos contra os pais... essas conversas tolas de juventude mal orientada... bem, as autoridades estavam planejando entrar na Faculdade e prender todo mundo. Pedi ao Delegado regional, Dr. Tácito, que não fizesse isso, afinal a juventude que estava lá nem sabia o que estava fazendo, pedi para eles não prenderem aluno.

Depois da reunião fui até a Faculdade e estava tendo um comício, chamei o presidente do diretório, acho que Murilo Farinazzo era o nome dele, expliquei a situação e pedi para eles pararem com aquilo, senão iria todo mundo preso. Ele falou com o pessoal e acabei vaiado, achavam que eu não estava do lado deles, na verdade eu não estava de lado nenhum, não queria que os prendessem.

No dia seguinte continuou tudo igual, então lavei as minhas mãos. Fui e falei para o meu colega que não iria assumir a responsabilidade, então eles foram lá e prenderam um monte de gente. O Cantoni mesmo fugiu para o Chile... sabe quando vem um regime forte com ou sem razão, a polícia excede...até um político falou que não tinha medo de ditadura, tinha medo do guarda da esquina, esse sim se excede.

Sabe, aconteceu primeiro a intervenção em Rio Preto porque esses professores e alunos já vinham marcados pelo povo. Uns dias antes da revolução teve até passeata pela família aqui, o povo estava revoltado contra a Faculdade porque eles estavam pegando pesado justamente contra os costumes da cidade, que eram costumes pacíficos... até em São Paulo houve aquele enfrentamento entre a USP Maria Antonia e o Mackenzie...

Agora aqui, como havia só uma faculdade a polícia teve que agir mesmo. Tinha um agitador, o Cunha, esse era um dos mais agitadores... tinha o Orestes, mas esse não era tanto, não se expunha muito... eles agiam dentro da própria sala de aula aconselhando os alunos a fazer isso ou aquilo... o comandante da polícia dessa época 
era o Eduardo Monteiro, que nós chamávamos de Bitu. Sabe, no ano passado teve um desfile em São Paulo e ele desfilou montado num cavalo. Ele é muito bom, muito consciencioso, não houve violência aqui, não machucaram ninguém, só prenderam e deixaram a policia civil resolver o problema.

$\mathrm{Na}$ civil tinha um delegado chamado Tácito Pinheiro... esse era meio complicadinho, causou toda essa situação política aqui, agressões, prisões... as agressões foram causadas pela policia civil, a militar não interveio, não.

Eu só tentei ajudar, inclusive depois de ter estourado a revolução, alguns professores queriam ir para São Paulo e ajudei que eles embarcassem para não serem presos, fiz o que pude, até comida para a família de um professor que era mais exaltado, apoiava o João Goulart, eu levei... ele tinha um monte de filhos...eu achava aquilo um absurdo. Eu não concordava com a posição dele, mas a família, os filhos, não podiam ficar sem comer.

Esse negócio de bater na porta de sujeito, tirá-lo de casa, prender, bater, matar, eu sou contra... sei que houve isso no movimento revolucionário, mas não há revolução que não tenha violência de ambas as partes, temos até o caso de um tenente que foi mandado para prender um grupo de terroristas que estava no Vale do Ribeira com o Lamarca... quando os terroristas conseguiram pegar os militares, esse tenente propôs um acordo, pediu para soltar os companheiros que ele ficava de refém, eles soltaram, mas o que fizeram com o coitado... as maiores barbaridades, mataram ele aos poucos, castraram o pobre... e o pior é que esse pessoal é que manda no Brasil agora, os políticos do Lula são os terroristas ferozes que mandam no Brasil agora... até premiaram a família do Lamarca e eu até hoje luto por uma pensão decente.

Sabe, não sou contra as ideias, tenho até amigos que eram considerados comunistas antes da revolução, tem o Cavalcante, o Rodrigues Lisboa, um jornalista cujo nome não lembro agora... eu tinha muita consideração por eles... não tenho nada contra as ideias, tenho contra a violência, seja de um lado ou de outro. 
Tudo foi por causa do João Goulart, ele não devia nem ter assumido, assumiu, depois fez um plebiscito e virou presidente, então ele pregava essa coisa do rico contra pobre, essa coisa que o MST está fazendo agora, começou a fazer uma inversão... quebrar a hierarquia, o João Goulart ia dar um Golpe, olha o comício que ele fez na Central do Brasil, os militares só deram um contragolpe antes dele fazer besteira, eles fizeram coisas boas, ficaram 20 anos mandando, não vou dizer que não houve desmando, mas você sabe... na revolução, seja onde for, você cerceia a liberdade para manter o novo regime, e quem fez as barbaridades não foi a cúpula, foi o guarda de esquina... isso aconteceu no mundo inteiro... esse negócio de matar dentro da prisão não foi coisa de chefes militares, a cúpula não comungava com essas barbaridades, a parte eu era comandada era que exagerava, veja no Iraque, na Venezuela, para manter o poder ou a sua posição tem que haver exageros, isso é normal, embora não seja o ideal.

Eu gostava muito do Mauricio Tragtemberg, ele era muito culto, sempre dava uma espezinhada nos militares, quando eu estava presente ele dizia que o Duque de Caxias era contrabandista, ríamos muito disso. Embora fosse muito culto, às vezes ele ficava pregando essas bobagens.

Os professores, embora, embora com essa visão de esquerda, eram entusiasmados, excelentes profissionais... depois da revolução, quando eles forma embora, o ensino caiu muito, os professores da região não eram tão capazes, tão entusiasmados. A qualidade de ensino caiu assustadoramente... depois foi conseguindo se levantar novamente, hoje é muito boa, é a UNESP. O próprio interventor era muito duro, o José de Castro Duarte, ele chegou colocar o Orestes para fora da Faculdade quando ele veio buscar uns livros dele.

Agora, a sociedade conservadora de Rio preto contribuiu para que tudo acontecesse, ela se revoltou contra a faculdade e apoiou a revolução. 


\section{ANÁLISE DAS ENTREVISTAS}

Como compreender e analisar as histórias que ouvimos, que se situam na fronteira das relações entre o que é exterior ao indivíduo e ao que ele traz em seu íntimo, com seus dilemas e contradições? Se nas entrevistas de História Oral de vida o que recolhemos são memórias, como interpretar o que ouvimos? Analisando a memória coletiva, Halbwachs enfatiza a força dos diferentes pontos de referência que estruturam nossa memória e que a inserem na coletividade a que pertencemos. Ainda segundo o mesmo autor:

"Para que a nossa memória se beneficie dos
outros, não basta que eles nos tragam seus
testemunhos: é preciso também que ela não
tenha deixado de concordar com suas
memórias e que haja suficientes pontos de
contato entre ela e as outras para que a
lembrança que os outros nos trazem possa ser
reconstruída sobre uma base
comum"(HALBWACHS, M.: 2006)

A leitura de uma ou mais entrevistas não é um trabalho simples. Neste trabalho delimito o problema da pesquisa que é a história dos envolvidos na intervenção de 1964 na FAFI, a própria intervenção e as conseqüências imediatas da mesma e a trajetória da Faculdade. Considerando que estou trabalhando com várias entrevistas, levei em conta as disposições que meu colaborador quis manifestar por meio da sua narrativa, e que o que emergiu delas se trata de uma construção que cada indivíduo elabora a partir da sua experiência.

Assim, pretendi analisar as narrativas, considerando o curso de vida de cada colaborador, o papel social desempenhado por eles em suas vidas, pois, como reconhece Éclea Bosi, as lembranças transmitidas por um indivíduo estão presas às suas trajetórias de vida, o que lhe permite oferecer um testemunho das transformações ocorridas ao seu redor e, ao mesmo tempo, produzir uma análise das mudanças por ele percebidas. 
Pretendi construir evidências e estabelecer correlações que possam contribuir para que os objetivos da pesquisa sejam alcançados da melhor forma possível. (DELGADO. 2007)

Segundo Meihy e Hollanda, análise em História Oral é um procedimento premeditado, especificado no projeto e disso dependente. (MEIHY, HOLLANDA. 2007)

Neste trabalho segui as seguintes etapas propostas por Lucilia de Almeida Delgado para a análise das narrativas:

- $\quad$ Análise temática do conteúdo das entrevistas, destacando-se temas gerais;

- Realização de uma nova análise das narrativas, de acordo com os temas destacados anteriormente, objetivando compreender o conteúdo das entrevistas, indicando sua especificidade;

- Realizar o agrupamento de um conjunto de entrevistas no qual cada entrevista possa se constituir como uma unidade especial, e o conjunto delas possa ser cruzado, comparando-se as versões e informações obtidas. (DELGADO.2007).

Após a análise das entrevistas procedi o cotejamento das mesmas com os documentos escritos para elaborar o que se segue nesse trabalho.

É importante, neste momento, descrever o contexto que acompanhou essas entrevistas. A maioria dos entrevistados se mostrou muito disposta a contar a história e pode-se perceber nas suas narrativas certa mágoa que ninguém ainda tivesse tido a idéia de contar a história da FAFI, como eles chamam a faculdade com um tom de nostalgia. Muitos deles me disseram que estava na hora da história ser contada. Um dos contatados, porém, se recusou a falar, demonstrou certo medo e disse que nunca mais queria ouvir falar daquele tempo horroroso.

Partindo da perspectiva que narrar é algo difícil, que exige um forte exercício da memória, as entrevistas foram longas e carregadas de silêncios. Percebi que, por vezes, eles significavam frustração, mágoa, saudade e por outras, a certeza de que o passado fora melhor que o presente. Nesse sentido, o passado sendo melhor que o presente foi muito comum ouvir nas narrativas que: “a educação naquela época era excelente", "que os jovens sabiam pensar" e que hoje a educação está um caos sem 
muita esperança de mudança. Esse tipo de afirmação me levou a Jerzi Szacki, que escreve sobre a questão das utopias ou felicidade imaginada. Para esse autor :

$$
\begin{aligned}
& \text { "Será utópico, para nós, todo revolucionário que desconhecer a } \\
& \text { idéia de um período intermediário, que imaginar uma } \\
& \text { transformação social que introduza uma quebra na } \\
& \text { continuidade histórica, como substituição direta das relações } \\
& \text { boas por más." ( SZACKI, J.:1972, p.16) }
\end{aligned}
$$

Assim o que se percebe nas narrativas, tanto de professores quanto de alunos é que o tempo passado foi diferente ou melhor que o tempo presente, assim como o lugar do passado é melhor. Aquela Faculdade de 1957 em São José do Rio Preto era sem dúvida melhor que a de hoje, embora as dificuldades fossem muito maiores, o espaço mais exíguo, eles afirmam que eram felizes, tinham esperança de transformação do mundo pela educação, e era lá, no interior que essa transformação se deu. A avaliação negativa do presente é acentuada pelo contraste de um passado melhor. ( SZACKI, J.:1972, p.16) 


\section{A criação da Faculdade}

Segundo Casemiro Reis Filho, em 1955, na cidade de São José do Rio Preto,

"Começou um movimento para se criar uma Faculdade. Eu defendi a criação de uma Faculdade de Direito, mas as pessoas achavam melhor criar uma Faculdade de Filosofia. Eu era contra a justificativa que o pessoal da cidade dava: queriam uma Faculdade de Filosofia porque assim as meninas não precisariam vir para São Paulo e "se perderem" aqui. Fui voto vencido". (REIS FILHO. 1984)

A Faculdade era uma aspiração da sociedade riopretense, mormente de um grupo de professores do Instituto de Educação Monsenhor Gonçalves, entre eles o professor Daud Jorge Simão, também vereador. No jornal O Estudante, edição de maio de 1955, publicado pelo grêmio do Monsenhor Gonçalves, o referido professor escreve um artigo longo onde defende a criação da Faculdade e termina assim a sua argumentação:

“Tiremos da frente aqueles que não acreditam nos valores culturais. Quando os cursos estiverem funcionando, busquemo-los para que se integrem na nova geração que emergirá das forças positivas que constroem e não daquelas que emperram o progresso da humanidade". (O ESTUDANTE. Maio/1955. No. 1)

A criação da Faculdade também foi defendida em um programa de rádio chamado A Voz do Estudante, no dia 5 de junho de 1955, produzido, escrito e dirigido por Antonio Luiz Pimentel na emissora PRB8 Rádio Rio Preto, uma das emissoras afiliadas á Rede Piratininga. A narração foi de Ebrahim Ramadan e o texto dizia o seguinte:

“O sonho de todos os estudantes de Rio Preto e região, foi realizado. Foi aprovado na Câmara Municipal o projeto de lei do Prof. Daud Jorge Simão que propunha a 
criação de uma universidade em São José do Rio Preto. Depois de duas ou três sessões inúteis, por falta de quorum, conseguiu-se, finalmente, reunir-se os senhores vereadores para a discussão do projeto. Magnífica e sensacional foi aquela noite, em que em nada menos de 5 horas se travou estrondosa discussão espetacularmente sustentada pelo Dr. Daud explicando àqueles que não entendiam ou não queriam entender, a finalidade e objetivo de seu projeto sobre a criação da universidade.[...] Resta-nos esperar e aguardar a decisão. Por enquanto queremos somente esternar os nossos agradecimentos ao professor Daud Jorge Simão e os nossos parabéns pela sua brilhante atuação em defesa da causa estudantil."51

O Prefeito de Rio Preto, Philadelpho Gouveia Neto, em 26 de maio de 1955, promulgou o Projeto de Lei no. 30/55, que dispunha sobre a criação da Universidade Municipal de São José do Rio Preto, e em 25 de agosto do mesmo ano o Decreto 249, criou a primeira unidade universitária riopretense: a Faculdade de Filosofia, Ciências e Letras. Em 13 de dezembro de 1955 chegou à cidade o Prof. Dr. Rafael Grisi, encarregado de ultimar os preparativos necessários à instalação e funcionamento da Faculdade. O Professor Grisi foi o primeiro diretor da instituição.

A Faculdade funcionou nos seus primeiros anos com recursos municipais, e em 1956, chegaram a Rio Preto os primeiros professores estrangeiros para lecionar nela. São eles Dr. Erich Arnold Von Bruggenhagen, Dr. Edoardo Querin e Dr. Antonio Pinto de Carvalho, e também os brasileiros Luiz Dino Vizotto e Celso Abade Mourão.

A municipalidade não conseguiu, porém sustentar a Faculdade e o dr. Aloysio Nunes Ferreira em 13 de setembro de 1956 pleiteou junto ao governo estadual a criação de uma Faculdade como Instituto Isolado do Sistema Estadual de Ensino

\footnotetext{
${ }^{51}$ Respeitei a grafia que estava no texto lido, pelo locutor.
} 
Superior. Somente em 1957, pressionado pelo prefeito Alberto Andaló a Faculdade foi estadualizada. Essa questão é colocada pelos nossos colaboradores:

“Primeiro tínhamos um Faculdade municipal, depois o Jânio estadualizou e transformou-a em Faculdade Isolada de São José do Rio Preto" (Profa. Nilce Lodi)

“O que vou contar agora foi uma reunião histórica. Encontramo-nos com o Jânio Quadros e o Alberto Andaló fez o pedido. Foi cômico! O Jânio com aquele jeito peculiar de falar disse: Allllbbbeeerrrrtooo Annndalóóóó, eu não posso te dar isssooo.. o que você está me pedindo é um absurdooooo... O Alberto ficou muito bravo. Ele era o principal cabo eleitoral do Jânio naquela região, um homem de muito prestígio, mas também um cavalo de mal-educado... virou as costas e disse ao Jânio: Então você vai pra puta que o pariu, nos chamou e fomos saindo... quando estávamos perto da porta o Jânio disse que nos daria a Faculdade". (Prof. Orestes Nigro)

Os principais jornais da cidade comemoram a conquista e em grande editoriais informaram à população:

“O grande benemérito. O Governador Jânio Quadros merece, sem favor nenhum, o título de grande benemérito da Faculdade de Filosofia, Ciências e Letras de São José do Rio Preto."(Correio da Araraquarense, 10 de abril de 1957).

"Sonho que se transforma em realidade: Rio Preto, mui justamente, festeja hoje um de seus maiores acontecimentos, qual seja a instalação da Faculdade de Filosofia, Ciências e Letras, da Universidade Municipal".(Correio da Araraquarense, 10 de abril de 1957).

“A nova Faculdade de Filosofia, Ciências e Letras de São José do Rio Preto é o novo centro regional de ensino e pesquisa a serviço do progresso técnico e social da região. Formação 
científica e pedagógica adequada de futuros professores do ensino secundário, ao lado da preparação de investigadores e especialistas de vários ramos do conhecimento humano."(Revista Atualidades Pedagógicas, Agosto de 1960, p35).

Vários artigos divulgados, inclusive, pelo Jornal Diário de São Paulo, dão a dimensão da importância da criação da FAFI. A carta convite para a aula magna foi publicada no jornal A Notícia. 52

Por que era tão importante a criação de uma Faculdade em Rio Preto? O final da Segunda Guerra imprimia ao país novas necessidades que a educação não podia ignorar. Era um período de transitoriedade em que havia intensa manifestação a respeito dos rumos do sistema educacional. A partir da década de 1950, havia dois processos fundamentais, ambos com grande repercussão sobre o encaminhamento das questões educacionais: um processo de redemocratização, com o fim da ditadura Vargas, e um processo de desenvolvimento comandado pela segunda industrialização. É dessa época a percepção de dois Brasis, um arcaico, tradicional, e outro moderno, e a crença em que o desenvolvimento de sua porção moderna levaria à superação das suas contradições, fazendo-o, finalmente dar o salto para o futuro.(LAMBERT. 1959)

A educação seria a maneira de transformar o Brasil em uma nação moderna. O educador e filósofo Anísio Teixeira, na década de 1950 ao fazer uma palestra no Rio de Janeiro alertava:

“(...) a educação não é apenas um processo de formação e aperfeiçoamento do homem, mas o processo econômico de desenvolver o capital humano da sociedade."(TEIXEIRA. 1957)

Parece que a preocupação com a qualidade da educação na recém criada Faculdade Isolada de São José do Rio Preto também afetava Jânio Quadros. O governador exigiu do prefeito Alberto Andaló que os professores da nova instituição

\footnotetext{
${ }^{52}$ Ver em Anexo 2
} 
fossem formados pela USP, e essa decisão teve sérias consequências. A professora Nilce Lodi conta que:

"Quando da estadualização foram contratados professores da USP com o Aloizio Reis de Andrade, o Casemiro Reis Filho[...] A faculdade era uma reivindicação da população de Rio Preto, era difícil mandar seus filhos estudarem na USP de São Paulo. Muita gente achava que era uma utopia uma faculdade no interior[...]Esses professores vieram para Rio Preto trazendo muitas novidades".

O professor Hélio Leite de Barros conta que:

“O Jânio estadualizou a Faculdade, mas exigiu professores da USP, não queria que a estadualização servisse para politicagem local."(Prof. Hélio Leite de Barros).

Eram professores jovens, vindos da capital para o interior com vontade de ensinar, despertaram nesse primeiro momento certa desconfiança, inclusive de seus pares da capital. Havia o receio de uma USP caipira, que não se concretizou. A Faculdade de Rio Preto obteve o grau de excelência pela maneira desses jovens professores encararem a educação. Casemiro dos Reis Filho, Wilson Cantoni, Orestes Nigro e outros fizeram com que a Faculdade se destacasse até 1964 pela seriedade, qualidade e entusiasmo com que alunos e professores se dedicavam às tarefas acadêmicas. Os alunos e professores entrevistados forma unânimes em afirmar essa excelência:

“Era uma Faculdade que formava, não só conteúdo, mas formava a mentalidade cientifica... havia seriedade sabe? E era assim em todos os cursos. Havia grandes profissionais... tínhamos certeza de que íamos ser grandes"(Edson Guiducci)

"Sabe, o trabalho em Rio Preto era estimulante, professores de nível muito bom querendo criar uma educação 
diferenciada. O Casemiro Reis Filho, O Orestes, o Azzi, o Cantoni, o Lövy, o Tragtenberg, a Sara..."(Prof. Hélio Leite de Barros)

“Eu gostava muito daqueles professores... havia o professor Orestes Nigro que se destacava pela popularidade e isso me influenciou." (Grigor Vartaniam)

"O ingresso na Fafi foi uma coisa maravilhosa e provocou em mim um grande amor. Era uma faculdade modelo, os professores eram da USP, tinham um jeito de ensinar... muito, muito bom, principalmente o de Sociologia, o Wilson Cantoni.. os de Filosofia, Aiex e Aloisio Reis de Andrade também eram especiais..." (Maria de Lourdes Cápua)

“Eu gostava muito do Mauricio Tragtenberg, ele era muito culto, sempre dava uma espezinhada nos militares, quando eu estava presente ele dizia que o Duque de Caxias era contrabandista, ríamos muito disso. “( Coronel Godói)

Os professores da FAFI vieram para Rio Preto com o intuito de criar um novo tipo de educação. Havia novos projetos culturais e ideológicos a serem colocados em prática. Os anos 1950 foram marcados por uma crise no moralismo rígido da sociedade. O sonho americano já não conseguia mais empolgar a juventude. A segunda metade dos anos 50 já prenunciava como seriam os anos 1960: a literatura beat de Kerouac, o rock de garagem, os movimentos do cinema e de teatro de vanguarda eram assuntos de interesse de jovens do mundo todo, inclusive dos brasileiros.

Os professores da FAFI faziam parte dessa juventude, muitos eram solteiros e os casados já viam o casamento com outros olhos. Os jovens de Rio Preto passaram a admirá-los e consequentemente pela educação que eles propunham. Os professores da Maria Antonia viam a questão da educação como fator primordial: 
“Resolvi que estudaria para ter uma vida melhor e lutaria para proporcionar uma vida melhor para outras pessoas também".(Prof. Orestes Nigro)

“Bem, nossa classe era muito rica intelectualmente, acho que não havia militantes políticos, mas militantes culturais. A gente queria, representava e procurava fazer algo para acontecer uma revolução na cabeça das pessoas, a gente trazia coisas novas, e claro, isso colidia com o padrão reinante que nos taxava de revolucionários" (Prof. Hélio Leite de Barros).

"Começamos a trabalhar cada um no seu setor. Tínhamos seminários diários de estudo para construir a escola que a gente imaginava... foi uma revolução o método que a gente começou. Pensávamos em fazer uma escola com predominância no sentido evolutivo do pensamento, tudo interligado, Artes, Filosofia, Pedagogia... a idéia era formar o homem brasileiro... queríamos criar possibilidade para que as pessoas pudessem pensar com mais amplitude... logo pensamos no teatro."(Profa. Sara Rotemberg)

“O que a gente constatava é que nessa Faculdade a relação entre alunos e professores era muito mais avançada e menos formal do que na maioria das faculdades da época. Havia camaradagem, intimidade e grande respeito."(Juca de Oliveira, ator).

\section{O GRUTA}

Nesse final dos anos 1950, havia pessoas, como o professor Orestes que encaravam a arte como uma forma muito importante de educação. Embora não se assumisse comunista, percebe-se na fala desse professor e de muitos de seus colegas e alunos a necessidade de abordar questões políticas e sociais em contexto nacional.

Os jovens queriam afirmarem-se como jovens e buscavam romper com as regras tradicionais de então. Refletiam e denunciavam as injustiças cometidas na 
sociedade na busca de um mundo mais equilibrado e honesto. Esse período correspondeu a uma fase de excepcional de florescimento da cultura brasileira. A politização das massas se tornou o terreno fértil sobre o qual frutificaram iniciativas de cultura popular como nunca havia ocorrido em épocas anteriores.(GORENDER, 1987).

No campo artístico, verificou-se um crescimento em diversas áreas, um sopro de entusiasmo renovador percorreu a música popular, o teatro e a literatura. É a fase de ouro do cinema novo, do Teatro de Arena, da arquitetura de Brasília. Um grande impulso intelectual acompanhou o maior movimento de massas da história brasileira. Tudo isso também repercutiu no campo da educação.(SILVA, 2006).

Havia uma mobilização nacionalista nos fins de 1950 e início dos 1960, que envolveu também a área cultural onde a produção foi marcada pelas propostas das esquerdas, principalmente do PCB. A cultura, então encarada como instrumento de transformação social andou junto com a política, não só nesse momento, mas durante toda a década de 1960.(PAES. 1997).

Surgiu então, um público interessado em ver abordadas, no palco, questões políticas em contexto nacional. Com esse objetivo, novos dramaturgos buscam na pobreza do interior e da periferia o protagonista ideal. Nasceu, assim, uma tendência que seria predominante nos anos seguintes. Gianfrancesco Guarnieri, Juca de Oliveira, Oduvaldo Vianna Filho, Augusto Boal, entre outros, fazem parte de uma geração que descobre nos problemas sociais a fonte de sua dramaturgia. Segundo Paulo Pontes, o povo é “a única fonte de identidade nacional”.(PONTES. 2001) Entendia-se por povo aquele que era explorado, que levava a vida à margem dos meios de produção do saber. A ideia de que os fracos, unindo-se, derrotam os fortes, ganhou muitas versões.

Os heróis que, supõe-se terem morrido por uma causa coletiva como Lampião, Antonio Conselheiro, Zumbi etc. , mereceram várias peças. Era a busca da brasilidade e a estreita vinculação entre arte e política.(RIDENTI. 2000). Por volta de 1955 havia uma concepção de que era importante ter uma participação de teatro de 
um grupo amador.(Vera Vertel in RIDENTI. 2000). Nessa tendência, surgiu na FAFI o GRUTA, Grupo de Teatro Amador, criado pelo professor Orestes Nigro com o auxílio de Juca de Oliveira e Gianfrancesco Guarnieri. Embora o referido professor diga não ter tido nenhuma motivação política para a criação do grupo, essa motivação aparece na entrevista do professor Orestes:

“O GRUTA era um grupo de teatro amador que, além de fazer arte, promovia vários eventos também. Eu o criei como opção de conhecimento para os alunos e também para me divertir, foi muito espontâneo, nada muito pesado. Levamos para se apresentar na Faculdade a Inezita Barros, que sabe tudo de folclore, a Maria Lívia São Marcos que era a maior violinista do Brasil; levamos o Guarnieri para fazer um conferência sobre teatro, ele acabou se tornando um grande amigo, tenho até algumas fotos dele jovenzinho. O Juca de Oliveira veio com ele e também ficou meu amigo. Tempos depois resolvemos fazer a Semana de Estudos Brasileiros, no mês de agosto, e convidei a companhia de teatro do Fernando Torres, marido da Fernanda Montenegro, para se apresentar em Rio Preto. [...] Eu tinha capacidade muito grande de organizar eventos culturais e eles foram acontecendo frequentemente, até que o Cantoni um dia me chamou e perguntou se eu tinha noção do alcance desse movimento todo, dessa organização do GRUTA, perguntou se eu percebia o que estávamos fazendo. Respondi a ele que não tinha intenção de fazer movimento nenhum, que tudo era uma grande diversão, porque eu vivia tudo aquilo artisticamente. Ele disse que organizássemos isso, que déssemos estrutura, fizéssemos um estatuto, porque iríamos crescer muito."(Prof. Orestes Nigro).

Embora negando a motivação política o Prof. Orestes criou um estatuto para o GRUTA, cuja cópia integra o processo militar, denominado "Objetivos e Carta de Princípios". Tal documento diz o seguinte: 
"I - O GRUTA tem por finalidade promover, através de instrumentos artísticos adquiridos na escola e dos trazidos de acervo artístico do povo, as seguintes metas: 1- a tomada de consciência das classes oprimidas através de seus problemas sócio-econômicos-culturais e conseqüente ruptura com esquemas sociais desatualizados. 2- a mobilização dos estudantes, no sentido de compreender a sua própria realidade e atuar sobre ele, assim como de preparar-se para atuar sobre a realidade das classes indiadas na nota 1.

II- Enquanto a realidade brasileira que se apresenta à nossa geração, é imperioso que cada cidadão empregue os meios de que dispõe, os instrumentos de cujo manejo está capacitado, a fim de oferecer sua contribuição para a solução dos problemas que caracterizam esta realidade, assim como lutar para atingir as condições indispensáveis à soberania nacional que implicam na emancipação econômica, política e cultural do povo brasileiro.

Os intelectuais, ou os assim chamados, os educadores, os universitários, todos temos como meio de luta e atuação, além dos instrumentos próprios ao trabalho do ensino, de pesquisa e de reflexão, os processos de manifestação artística, os quais, dentre todos são os que melhor comunicam ao povo, e que melhor manejo é nos dado praticar. Assim, os universitários da Faculdade de Filosofia, Ciências e Letras meramente entretenedores que possa ter a arte de um povo sem problemas e também, embora não afirmando se esta a arma mais eficaz de luta, dentro de um plano geral dispõe-se a empreender com a serenidade de uma militância, um trabalho de cultura popular que abranja seus dois caminhos naturais: aquele de levar ao povo a mensagem de luta e o trazer do povo todas as suas virtualidades culturais, dando-lhe a dignidade e a imensa significação que a sua autenticidade garante. 
Para o membro do GRUTA o trabalho artístico é um ato cívico, revolucionário e por isso patriótico, não se reconhecerá nas demonstrações de afirmação pessoal ou do grupo, tão abundantes nos meios artísticos convencionais, uma manifestação própria ao GRUTA. Na segurança e na plena confiança do sentido autêntico da cultura popular, subscrevemos nossa Carta de Princípios".

Observa-se que a participação, tanto da parte de artistas como de intelectuais, foi considerada prioritária, tentando-se, através dela, um trabalho comum, tendo de um lado a massa da população brasileira e, de outro, o meio intelectual e artístico. (AMARAL,1984). Percebe-se que um fenômeno novo parecia tornar-se muito nítido: a consideração do "popular" para o meio intelectual e artístico, a arte contribuindo vigorosamente para chamar a atenção de um número maior de pessoas. A Faculdade e seus integrantes aparecem como elementos-chave para mudar a realidade brasileira.

Em Rio Preto o GRUTA apresentou o Teatro de Arena para audiências populares de bairros periféricos que ocuparam as instalações de um circo.(OLIVEIRA. 1989, p.198) O GRUTA desenvolvia trabalhos artísticos seguidos de análises criticas e debate com a população presentes nesses espetáculos. Suas práticas, maneiras de trabalhar, o modo como incomodou muitas pessoa, estão presentes na fala dos colaboradores e nos depoimentos colhidos pela polícia quando da intervenção da Faculdade:

“Eu tinha uma capacidade muito grande de realizar eventos culturais de peso e eles foram acontecendo frequentemente [...] O grupo empolgou muito e as pessoas foram cada vez mais participando, o Edson Guiducci, o Grigor Vartaniam, a Eudete Fochi, que se transformou no meu braço direito, ela tinha uma cabeça muito boa... a Isabel... convidamos o Rubens Paiva, que era um deputado empresário e tinha uma 
visão muito aberta, para fazer uma palestra lá, veio o Antonio Cândido..." (Prof. Orestes Nigro)

“Por volta dos anos 60, eu fazia parte de um grupo de teatro chamado Arena que, de vez em quando, fazia excursões pelo Brasil para mostrar as peças encenadas em São Paulo. Íamos para o nordeste, para o sul do país e também para o interior de São Paulo, inclusive São José do Rio Preto, cidade que passamos a visitar sempre que possível. Nosso primeiro contato lá foi um grupo de teatro que havia na Faculdade, a FafiOrestes, homem preocupado com questões sociais, organizara o seu grupo de teatro dentro da Faculdade, a partir da música, violão, canto em permanentes saraus alegres e muito concorridos pelos estudantes. Claro que as questões sociais estavam sempre presentes nessas reuniões. O contato com esse grupo e o Teatro de Arena se tornou muito estreito. Lá encenamos algumas de nossas peças. Eu mesmo voltei várias vezes a Rio Preto, onde apresentei dois recitais de poesia. Também fazíamos palestras sobre Teatro, Guarnieri falava sobre dramaturgia, Boal sobre direção. "(Juca de Oliveira)

“Sei que a mesma altura se fundou o GRUTA, e se a memória não me falha, este foi animado pelo Orestes Nigro, mas confesso que não tenho qualquer recordação concreta do GRUTA, que tão pouco deve ter tido uma ligação institucional com a Fafi. Não houve entre o GRUTA e o MPC nem ligação institucional, nem informal, para além daquilo que uns e outros poderiam chamar de contatos institucionais". (Franz Wilheim Heimer)

“Agora, havia a militância, o Heimer com a AP, o MPC, era intensa, o Azzi com o partidão...[...] Como eu gostava de cinema acabei me engajando, dirigia um pouco de cinema. $\mathrm{O}$ MPC estava ligado ao GRUTA, ao Ferreira Gullar, ao Augusto Boal, o Guarnieri, ao Juca de Oliveira... O Orestes também era 
do MPC, participava das reuniões para discutir estratégias." (Prof. Hélio Leite de Barros)

“O GRUTA trabalhava com cultura." (Maria de Lourdes Cápua).

“Tinha o GRUTA, o Heimer com o Centro Popular de Cultura, a AP... eram grupos que estavam voltados para as questões sociais. Não havia partido político."(Profa. Nilce Aparecida Lodi).

“Logo no início me integrei com o grupo do Orestes, o GRUTA... sabe eu cantava moda de viola, gostava de poesia e o GRUTA era um grupo artístico... nem sei o que estava fazendo num curso de Ciências...passei a participar muito do grupo e o Orestes era nosso grande guru, um verdadeiro líder.

Nossa preocupação maior era com aquele período político, na verdade não tínhamos preocupação de fazer sucesso... afinal muitos já trabalhavam, inclusive eu... embora alguns só estudassem. Fazíamos todo tipo de arte, cheguei a escrever, inclusive, algumas peças de teatro, versos... fazíamos grandes apresentações, tínhamos até um grupo de jogral. " (Edson Guiducci)

Nos depoimentos, constam também, a cópia de um caderno da disciplina de Pesquisa em Sociologia da aluna Flávia J. Pereira onde o GRUTA aparece assim:

\section{“GRUTA}

Finalidade: Conscientizar movimento local. Não tem plataforma ideológica explicitada. Uso da arte como meio de ação.

Liderança: O grupo existe em torno do líder -líder potervaliosa. 
Tipo de relação: Relação pessoal com o grupo e influência de um grupo radical: maior atividade e mais afinidade com a atitude psicológica do líder." (P. 554 do processo militar).

“...tem conhecimento do GRUTA, órgão independente e que se destina ao desenvolvimento cultural e artístico da população de Rio preto; que, no campo do teatro, tem conhecimento apenas de uma apresentação na Faculdade, da peça "Auto dos 99\%" que para o declarante, vera sobre problemas na Universidade Brasileira; que em relação a outras peças apresentadas pelo GRUTA, desconhece-lhes o assunto, apena tendo ouvido breves referências."(Depoimento do Prof. Hélio Leite de Barros, p 384 do processo militar."

Sobre o GRUTA, ainda existe um oficio endereçado ao Dr. Delegado Regional de Polícia, que era o Dr. Tácito Pinheiro Machado, assinado por dois delegados locais, Dr. Mariano Pereira de Andrade e Dr. José Domingos Ferreira que diz o seguinte:

"Sobre as diligencias encetadas para a apuração de possíveis práticas subversivas por professores da Faculdade de Filosofia desta cidade de São José do Rio Preto, nesta altura, já permitem admitir que o movimento da AP desenvolvido nesta entidade estundantil, por alguns professores, e coordenado pelo professor Franz Heimer, já se encontrava em fase de ação, quer através do MPC e GRUTA, órgãos dos estudantes locais.

Quanto ao propósito subversivo basta dizer que este movimento, outro fim não possuía, senão transformar ${ }^{53}$ a estrutura sócio-econômica do paíz ${ }^{54}$, até mesmo pela violência [...]" ( P 1032 do processo militar).

Ainda no depoimento de Vanda Aparecida de Lima, aluna, consta o seguinte:

\footnotetext{
${ }^{53}$ Grifo do escrivão de polícia no documento original.
}

${ }^{54}$ Grafia constante no documento original. 
“... que o coordenador do GRUTA é o professor Orestes Nigro; que trata-se de grupo, cuja finalidade é a politização do povo, através da arte dramática; que o GRUTA segue também ideologia de esquerda, o mesmo acontecendo com o CAF, MPC e PAI, sendo este último Partido Acadêmico Independente." 55 (p. 1572 do processo militar)

Percebe-se pelas narrativas que os integrantes do GRUTA queriam mudanças sociais radicais e que o teatro era um meio para que elas acontecessem, porém não tinham propostas político-partidárias. Eles tinham consciência dos problemas sociopolíticos e econômicos do seu tempo. O teatro foi o meio escolhido por eles para tentar mudar e conscientizar as pessoas porque acreditavam que era o único meio de agir diretamente sobre a consciência das pessoas, portanto um instrumento ativo e enérgico, capaz de revolucionar a ordem social vigente. Antonin Artaud pensa o teatro dessa maneira também, isto é, a revolução deve ocorrer "pela cultura, na cultura" (FELÍCIO.1996)

No prefácio de O teatro e seu duplo, ele reflete sobre a cultura contrapondo duas diferentes formas de compreendê-la. Uma, dominante na sociedade ocidental, coloca a cultura como algo separado da vida, como um sistema de conhecimentos, informações, instrução. Esta visão de cultura traz consigo uma noção elitista e dualista - o culto e o inculto - a idéia da "aquisição" de cultura que remete a uma desconexão. “Como se de um lado estivesse a cultura e do outro a vida; e como se a verdadeira cultura não fosse um meio refinado de compreender e exercer a vida" (ARTAUD, 1993).

Em oposição a esta "idolatria da cultura", ele apresenta a idéia da "cultura em ação", que se torna no homem como que um novo órgão, uma espécie de segundo espírito e que rege as ações mais sutis, o espírito presente nas coisas. Esta cultura é a autêntica, segundo ele. A cultura funde-se com a vida e a vida com a cultura, promovendo a integração do ser humano. Assim, “A verdadeira cultura pressupõe

\footnotetext{
${ }^{55}$ Manterei, neste trabalho, a grafia original nas transcrições dos documentos.
} 
uma modificação integral, mágica, do ser no homem, numa união entre corpo e espírito, em que este último é cultivado no corpo que, por sua vez, trabalha o espírito" (FELÍCIO, 1996).

Assim como a revolução de Artaud passa por uma transformação na maneira da sociedade compreender a vida, para os integrantes do GRUTA, além de compreendê-la o teatro pretendia transformações nas estruturas mais profundas, na forma da sociedade viver suas relações, não como indivíduos isolados, mas como um ser integrado ao social. A arte não era algo a se apreciar, mas algo a ser vivido.

É interessante notar, porém, que embora os colaboradores sempre apresentem o GRUTA, o MPC e a AP interligados, seus criadores não o fazem. Tanto o Professor Orestes quanto o Professor Heimer tentam anular a importância desses movimentos dentro da FAFI. Além disso, procuram desviar o assunto quando indagados sobre eles e, por vezes, característica mais notada no professor Heimer, optam pelo silêncio. Assim como as palavras, o silêncio está determinado por suas condições de produção.

Segundo Eni Orlandi há muitas formas de silêncio; entre elas estão o "silêncio imposto" e o "silêncio proposto". O imposto significa exclusão, e é forma de dominação, já o proposto vem do oprimido e representa uma forma de resistência, e creio que caiba acrescentar que também pode significar uma forma de defesa ou de auto-proteção. Possivelmente o conceito de "silêncio proposto" pode ser aplicado a ambos os professores. É preciso levar em consideração que a censura se instaurou como um fato nos idos dos anos 1960. Em tempos de ditadura há uma predominância do "silêncio imposto", onde o regime "proíbe certas palavras para se proibirem certos sentidos"(ORLANDI, 1991). Esse tipo de silêncio provoca nos indivíduos de uma sociedade o medo. Ele é tão grande, que mesmo após o período de dominação ele continua presente. Marco Antonio De La Parra, escritor chileno escreve sobre esse medo: 
“Me da miedo hablarle. Sabia? Me da miedo dirigirle la palabra. A mi padre Le daria miedo si supiera que estoy a solas com usted. A mi madre también. A mis hijos no sé, son más valientes que yo, son de otra generación. Tal vez no sean ni valientes. Tal ellos no entiendan mi cautela, el efecto de su presencia em mi lenguaje, el impacto...usted sabe...em mis palabras, Es decir em mi espíritu. A mi usted me da miedo." (DE LA PARRA, 1998).

Fica claro no texto acima que o nome, a figura, a presença do ditador causaram e continuam causando medo, afinal o escritor viveu o tempo do "silêncio imposto." É possível que esse mesmo tipo de medo perdure, fazendo parte, de forma já inevitável, do imaginário dos dois professores, mesmo que inconscientemente, pois nenhum deles se referiu a esse medo. Pude perceber na narrativa de todos os colaboradores esse silêncio incômodo, presente, repleto de significados. Dentre todos, apenas um colocou em palavras o que sentia sobre o silêncio:

“Em novembro de 1963 o presidente Kennedy foi morto. Fiquei em choque. Lembro que o Professor Prósperi me pegou pelo braço e disse:- "Grigor, te proíbo de abrir a boca, de ir nessas assembléias, você é muito impulsivo e tenho certeza que essa morte é sinal que virá uma revolução de direita na América do Sul, principalmente no nosso país... os líderes de esquerda vão ser implacavelmente perseguidos... não quero você metido nisso, não quero ninguém apontando para você e dizendo que você era comunista."Obedeci, em parte. Diminui a freqüência nas assembléias.

Foi um trauma ter sido preso. Depois disso fiquei com a boca cerrada, não falava nunca o que eu pensava, tinha um medo danado de me expressar, de me expor... fico admirado com o direito das pessoas falarem hoje, nós falávamos $10 \%$ disso e olha o que aconteceu... essas pessoas de hoje seriam degoladas! Se eu voltasse no tempo, acho que com a experiência 
que tenho hoje... vendo como você tem pouca gerência sobre as coisas que acontecem na sua vida... acho que resolveria as coisas sem causar nenhum conflito.

Tenho três filhos e eles são mais calmos, mais conservadores, ensinei a eles que não conseguimos mudar a gente mesmo, que dirá o mundo? Se você não puder falar alguma coisa é melhor não falar nada."(Grigor Vartanian).

Penso que o silêncio desses professores não é ausência de linguagem, de significado, de sentido; também não é "complemento de linguagem". Ele tem significância própria [...] o silêncio não está apenas entre as palavras. Ele as atravessa. Acontecimento essencial da significação, ele é matéria significante por excelência".(ORLANDI,2002)

Está bastante claro nas narrativas e nos depoimentos do processo militar que o GRUTA e o MPC tivessem ligação, se não em todos os pontos, pelo menos em um deles: na alfabetização de adultos. O professor Heimer tinha profunda ligação com Paulo Freire e com o MCP e é sabido que o Movimento de Cultura Popular tinha como objetivos, segundo Cunha e Góes (1985),

\footnotetext{
“promover e incentivar a educação de crianças, adolescentes e adultos; atender ao objetivo fundamental da educação, que é o de desenvolver plenamente todas as virtualidades do ser humano; proporcionar a elevação do nível cultural do povo; colaborar para a melhoria do nível material do povo. Formar quadros destinados a interpretar, sistematizar e transmitir os múltiplos aspectos da cultura popular."
}

Assim como o MPC, o GRUTA também queria o desenvolvimento de uma cultura mais autenticamente nacional, buscando as raízes dessa cultura e transformando o povo pela alfabetização. O movimento de alfabetização de adultos é visto de maneiras diferentes por colaboradores e alguns depoentes do processo militar ligados a elite riopretense: 
“... O Heimer fundou a AP e fazia parte da JUC, junto com o GRUTA formaram a alfabetização de adultos... foram todos presos." (Profa. Sara Rotenberg)

"Víamos a necessidade de alfabetizar os adultos para que eles tivessem a possibilidade de melhorar de vida. Formamos alguns núcleos, eu a Cidinha, a Lederci, enfim, as meninas da Pedagogia junto com a Professora Maria Edith di Giorgi. Por causa disso acabaram cadeia em celas junto com as prostitutas. Fui até falar com o bispo auxiliar, pedir ajuda, mas o delegado se recusou a recebê-lo. Que idéia mais espetafurdia, achar que alfabetização de adultos tinha a ver como o comunismo."(Profa. Nilce Lodi).

“... o Gruta que trabalhava com cultura, o Heimer, que fundou a AP, com a alfabetização de adultos...fiz até o treinamento, e foi por causa desse movimento que viramos vítimas. Fazíamos o trabalho numa escola no bairro Esplanada, a noite, porém outros professores como o Newton Ramos de Oliveira trabalhavam em outros locais... foi um trabalho muito bonito e isso me emociona muito... são tantas lembranças."(Maria de Lourdes Cápua)

“Em contrapartida (movimento de alfabetização), participaram duas ou três dúzias de estudantes, e foram esses que se encarregaram da única atividade que chegou a concretizar-se, ou seja, um ou dois grupos de alfabetização em fazendas próximas a São José do Rio Preto" (Prof. Franz Wilheim Heimer)

"O único contato que tivemos com camponeses foi quando o fazendeiro Olavo Fleury permitiu que alfabetizássemos seus empregados pelo método Paulo Freire. $\mathrm{O}$ Olavo permitiu e isso até nos prejudicou. Quando fomos presos isso depôs contra nós, mas ninguém chamou o Olavo para depor, afinal ele era parte da elite."(Prof. Orestes Nigro) 
Nos depoimentos que constam no processo militar encontramos a seguinte conclusão em ofício assinado pelos delegados Andrade e Ferreira:

“A simples leitura das declarações do Prof. Franz e do Sr. Ethevaldo Mello de Siqueira e finalmente o apoio que tal movimento recebia dos órgãos federais então subordinados ao Sr. João Goulart, revelam o quão sérias seriam as consequências desse movimento. Entendemos Sr. Regional, ser indispensável o encaminhamento desse professor à Delegacia especializada do DOPS".(Oficio endereçado ao Dr. Delegado regional pelos delegados Mariano Pereira de Andrade e José Domingos Ferreira, constante no processo militar na $\mathrm{p}$ 1032)

O professor Heimer foi o único professor encaminhado ao DOPS, onde segundo ele ficou alguns dias. Ele fez tal afirmação na entrevista que me concedeu.

Segundo o depoente Euclides Pelacani:

..."no decorrer do mês de janeiro p.passado, talvez no princípio, apareceram na fazenda onde trabalha uns professores de São José do Rio Preto, de nomes Nilton e Orestes, e as moças que os acompanhavam, Lederci Gigante e Eliza Penhavel; que durante uns quinze dias os professores ficaram tomando dados dos alunos que quisessem ser alfabetizados em quarenta dias; que convidaram para freqüentar a escola de adultos, tanto velhos como moços, crianças, sendo que "insistiam muito para que todos entrassem na escola, chegando mesmo a obrigar"; que inicialmente ensinavam e mostravam as letras do alfabeto, passando inclusive filmes de figuras como por exemplo casa, cavalo e seus respectivos nomes, de onde os alunos copiavam; que esse tipo de ensino durou uns quinze dias Quando os professores então passaram a perguntar aos alunos se sabiam o que era sindicato, reforma agrária, se o patrão era bom com els(alunos) [...]"que os professores não falassem ao professor ou ao 
administrador o que se passava na escola, que era para ficar entre nós". ((Euclides Pelacani, aluno da alfabetização de adultos, p. 1160 do processo militar)

“... foi matriculado por tais professores que ficou sabendo chamar-se Nilton, Lederci e Orestes, sendo que uns outros mais nem ficou sabendo o nome[...] que juntamente com 37 outras pessoas passou a freqüentar as aulas, na sala da máquina da fazenda, cedida pelo proprietário uma vez que os referidos professores haviam anunciado um curso de alfabetização em apenas 40 dias, pelo fato de ser diferente daquele ensino comum feito durante o dia. [...] diziam que o patrão era rico sozinho e eles que trabalhavam eram pobres, referiam-se muito a uma tal SUPRA, dizendo que esta ia resolver o problema do pessoal da lavoura, necessitando para tanto formar um sindicato". (Sebastião José da Rocha, aluno da alfabetização de adultos, p. 1161 do processo militar)

Possivelmente o GRUTA, o MPC e a AP estivessem interligados em Rio Preto, partindo da análise da documentação amealhada. Em 1961 já havia o MEB, Movimento de Educação de Base, que surgiu como uma iniciativa da Igreja Católica, à qual pertencia o Prof. Heimer, que fazia, inclusive, parte da JUC, Juventude Universitária Católica. O MCP, nascido no Recife, do qual participava Paulo Freire, amigo do prof. Heimer, tinha objetivo de alfabetizar utilizando novos métodos, por meio de debates, por exemplo. O CPC, Centro Popular de Cultura ligado a UNE, União Nacional dos Estudantes, congregava artistas e intelectuais da época. Os principais agentes de sua criação foram três atores do Teatro de Arena, Oduvaldo Viana Filho, Carlos Estevam Martins e Leon Hirzman, desse teatro também faziam parte Gianfrancesco Guarnieri e Juca de Oliveira, muito ligados ao professor Orestes e ao GRUTA. O objetivo do CPC era levar cultura às classes mais desfavorecidas da sociedade, utilizando para isso peças teatrais, e em 1963 foi criado o departamento de alfabetização de adultos. 
Por que os professores se esforçam para minimizar sua atuação e outros colaboradores e depoentes apresentam narrativas que dão uma ideia diferente dos mesmos acontecimentos?

A memória coletiva, esta deve ser compreendida como um fenômeno coletivo e social, individualmente seria formada na interação social, ou seja, no convívio entre indivíduos e suas tradições. Portanto, ela é uma operação coletiva e, sobretudo seletiva dos acontecimentos e das perspectivas do passado, sendo impossível pensar em alguma memória coletiva que não tenha se desenvolvido em um quadro especial. (HALBWACHS, 1990).

Para Pierre Nora existem os "lugares da memória", onde o local é concebido como um espaço material, simbólico e funcional, no qual se engendra uma parte da memória nacional. Portanto, baseando-se no conceito de memória coletiva adotado por Halbwachs pode-se afirmar que a memória construída pelos integrantes do GRUTA e do MPC de São José do Rio Preto é um exemplo de formação de memória coletiva, pois ambos estavam ligados ao contexto das experiências vividas naquele lugar. As memórias formadas nesses "lugares de memória" nem sempre se lembram das mesmas coisas, ainda mais que no caso da Ditadura brasileira desenvolveu-se um embate entre as memórias oficiais e as subterrâneas, ocorrendo um enquadramento da memória, pois nem tudo foi divulgado, algumas não querem se revelar, ainda hoje, enquanto outras lutam para que isso aconteça.

Além das questões dos movimentos culturais em São José do Rio Preto, sabe-se que desde o inicio se estabeleceu um embate entre professores da cidade versus professores da USP e entre esses últimos e a elite da cidade.

Para Zuleika Aum Attab, a “Faculdade de Filosofia, Ciências e Letras de São José do Rio Preto foi implantada sofrendo hostilidade, até certo ponto latente da área municipal e suportando também o impacto da hostilidade manifesta dos círculos universitários da capital do Estado"(ATTAB. 1973). Para Newton Ramos de Oliveira 
"a classe dominante local e seus intelectuais" pretendiam implantar "uma escola que formasse estudiosos tradicionais e adaptados ao sistema, capazes de atuar com neutralidade acadêmica". Mas, "quando a Filosofia se instalou e adotou como lema a frase de Kant- Sapere Aude"- a camada enriquecida de Rio Preto "não imaginou que o pensamento fosse atualizado, envolvendo práxis coletiva institucionalizada por um ágil e democrático sistema departamental." (OLIVEIRA, 1989)

Alguns professores da cidade, entre eles Daud Jorge Simão, não concordavam, em absoluto, com a vinda dos professores da USP, chamados por eles de "estrangeiros". Pessoas respeitadas na comunidade, professores do Monsenhor Gonçalves, uma das mais respeitadas escolas secundárias de Rio Preto, também faziam parte da elite da cidade.

As práticas não ortodoxas dos professores da USP não agradavam a sociedade elitizada que criava suas filhas para o casamento. Era necessário estudar, mas não mudar a sociedade, segundo suas convicções. Travou-se inicialmente um embate entre professores da cidade, da Pedagogia e Letras e da História Natural. A questão era a representação paritária. Enquanto os professores da Letras e Pedagogia a defendiam, os de História Natural a abominavam:

“Voltando à Rio Preto, foi a primeira faculdade do Brasil que teve representação paritária e isso foi uma grande revolução na educação... também nos valeu a pecha de comunas de Rio Preto...a coisa não era engolida pelo pessoal das ciências naturais... a única coisa ruim eram as reuniões... sempre achei reunião uma porra...acho que nesses momentos a democracia é meio cansativa... acho que no final das reuniões todo mundo queria dizer:- vamos acabar logo com essa lengalenga, mas era muito divertido."(Prof. Hélio Leite de Barros)

"Além disso, a Faculdade tinha problemas internos, um deles era a idéia de departamento, 
representatividade, os professores da Letras e da pedagogia eram mais abertos, os da História Natural não eram vistos com agrado.

Os alunos da Letras e da Pedagogia tinham representantes dentro do departamento e tínhamos o direito de modificar algumas coisas indo até contra professores, que acatavam a nossa decisão. Havia também uma interdisciplinaridade entre nós, diálogo. O pessoal da História Natural nunca aceitou isso e a distância entre os departamentos e as pessoas que os compunham foi aumentando. Essa falta de convivência resultou em falta de harmonia."(Profa. Nilce Lodi)

"Participação dos alunos nos problemas da escola como membros de órgão colegiados; deve e pode haver essa participação, pois entendo que eles têm contribuição a dar, mas do modo como tem funcionado, a participação deles tem sido mínima, pelo menos o que tenho observado". (Prof. Celso Abade Mourão)

“O fato era que esses grupos se chocavam desde 1955, havia esse grupo que tinha uma ideologia que se chocava com a comunidade, e também com a gente da História Natural que não éramos políticos, com exceção do Cunha... mas eu me dava bem com todos eles... costumavam dizer que tinham um projeto pedagógico, não vi nada disso...Cantoni chegou a publicar um trabalho sobre a questão da representação de alunos, na verdade ela já existia, mas era um ou dois alunos por departamento, agora ter uma igualdade... bem nós da História Natural não éramos políticos..."(Prof. Luiz Dino Vizotto)

$\mathrm{Na}$ representação paritária da FAFI alunos e professores estavam em mesmo número para decidir os caminhos da Faculdade. Os professores “estrangeiros" apoiavam essa decisão, os da História Natural, não, com exceção do Prof. João Jorge Cunha. 
Outro problema enfrentado foi com relação ao diretor , o senhor Rafael Grisi. As narrativas dizem o seguinte a esse respeito:

"Quanto a administração de Rafel Grisi: aspecto positivo: a biblioteca, que conta atualmente com quase 40.000 volumes. Se nós fizermos um levantamento do crescimento da biblioteca em cada uma das administrações, verificaremos que a biblioteca da Faculdade de Filosofia já começou grande e assim começou porque o professor Rafael Grisi a criou grande. Quanto à qualidade do material, porque quantidade, mas de má qualidade não é vantagem, dizem que a biblioteca não valia muito a pena, porque a qualidade não era a das melhores. Acho que ninguém tem o direito de dizer isso, pois numa biblioteca cabe qualquer livro, por essa razão, esse eu considero um ponto positivo. Ponto negativo na administração de Rafel Grisi: ele poderia estar presente em Rio Preto mais do que esteve."(Prof. Celso Abade Mourão)

“Houve outro problema sério: o diretor, Dr. Rafael Grisi, praticava várias irregularidades, usava transporte público para fins particulares, não ficava na faculdade, suspeita-se que desviava verbas, e isso nos levou a escrever várias denúncias para o secretário da educação, e também nos valeu uma demissão, ele não renovou nossos contratos, porém por pressão dos alunos teve que nos readmitir. Isso foi por volta de 1963." (Prof. Orestes Nigro)

“Bem, sob a direção do Rafael Grisi a faculdade quase desandou, uma ilha de corrupção, sorte que lá havia gente muito boa, o Orestes Nigro, o Flávio de Giorgi, a Maria Edith di Giorgi, entre outros e não deixamos a coisa degringolar."(Prof. Hélio Leite de Barros)

Na residência do prof. Heimer foram encontradas várias cartas, a maioria dirigida ao chefe de gabinete do secretário da educação Chopim Tavares de Lima 
denunciando o diretor Sr. Rafael Grisi por improbidade administrativa e corrupção, algumas assinadas por vários professores da Letras e Pedagogia. Junto com as cartas havia um telegrama de Chopin que dizia:

"Recebi sua carta PT Tomei providências enérgicas PT Estou esperançoso solução favorável PT Seja reservado PT Chopim Tavares de Lima Chefe de Gabinete"

Após o afastamento do diretor Grisi, assumiu o Dr. João Dias da Silveira, estimado pelos professores. A sociedade riopretense, porém não aceitava as mudanças colocadas em prática pelos novos educadores. Alunos não precisavam ir de sapatos para a Faculdade, podiam usar chinelos. Os ternos eram dispensados e permitia-se, inclusive bermudas. Os colaboradores descreveram as relações entre sociedade e professores da FAFI:

“Embora fossemos bastante engajados, foi uma surpresa o Golpe. Claro que esperávamos algum tipo de represália, estávamos mexendo muito com a sociedade, mas o Golpe na faculdade ninguém esperava."(Prof. Hélio Leite de Barros)

“...sabe esses professores estrangeiros eram mais conservadores, mais adequados a cidade de São José do Rio Preto, na época, bastante provinciana que costumava olhar os professores e alunos da Fafi com muita desconfiança. Cansei de ouvir o seguinte conselho: "Olha você vai estudar na Fafi, mas não se envolva com as pessoas de lá, lá o negócio é perigoso". Esse se aplicava, não aos europeus, mas aos professores egressos da USP, que se trajavam de um modo diferente eram mais "inconvenientes" eram menos formais, porém percebi que lá tudo era coletividade, eu não era um alienígena, fazia parte de um todo."(Grigor Vartanian)

“...alguns professores eram os mais entusiasmados, começaram a pregar a destruição da família, a revolta do sistema familiar, falavam sobre como as mulheres deveriam agir e vestir, havia algumas exageradas que começaram a usar 
vestidos curtos, mostrando a calcinha, sentavam na rua, fumavam charutos, agrediam a sociedade. $\mathrm{O}$ povo, em geral se revoltou, não queriam isso, não estavam acostumados.Houve exagero por parte dos alunos, incentivados por professores que pregavam a revolta dos filhos contra os pais... essas conversas tolas de juventude mal orientada...

Sabe, aconteceu primeiro a intervenção em Rio Preto porque esses professores e alunos já vinham marcados pelo povo. Uns dias antes da revolução teve até passeata pela família aqui, o povo estava revoltado contra a Faculdade porque eles estavam pegando pesado justamente contra os costumes da cidade, que eram costumes pacíficos... até em São Paulo houve aquele enfrentamento entre a USP Maria Antonia e o Mackenzie..."

Agora, a sociedade conservadora de Rio preto contribuiu para que tudo acontecesse, ela se revoltou contra a faculdade e apoiou a revolução." (Coronel Godói)

"Rio Preto era o centro comercial da região, havia uma elite, muita fazenda de gado, agricultura... as outras cidades eram incipientes, como Tanabi, Jales, Votuporanga. Rio Preto tinha intelectuais, poetas como o Jamil Almansur Hadad, o Mauricio Goulart, grande historiador, o Rui Nazareth, um médico e também político que se juntou a nós.

Não entramos muito em contato com a população... a não ser com nossos alunos. Com eles íamos tomar sopa depois das aulas, toda noite, era um relacionamento maravilhoso, éramos os mentores, não só intelectuais, mas de tudo, de hábitos... começamos a mostrar a liberdade com responsabilidade... era natural que fosse diferente dos costumes da cidade... tínhamos uma formação diferente... “(Profa. Sara Rotenberg) 
“Esses professores vieram para Rio Preto trazendo muitas novidades. Nesse período o prefeito era o Dr. Andaló e a cidade passava por um desenvolvimento tremendo. Nesse primeiro momento, a Faculdade ainda municipal, esses professores foram acolhidos, a elite ficou entusiasmada por ter com quem conversar, afinal eram estrangeiros, algumas vezes o salário deles atrasava, mas sempre tinha alguém para ajudar, como o Quincas Pereira, por exemplo. Com a estadualização a proposta inicial da Faculdade foi mudando: era necessário com que se conversasse a respeito de tudo, se refletisse sobre todos os problemas e que se colocasse as diversas faces deles, isso foi gerando novas atitudes na geração jovem, nos alunos. Não havia mais dogmas, podíamos discutir e encontrar nossa própria resposta, muitas vezes ela coincidia com respostas já estabelecidas, outras não. Os pais perceberam que seus filhos já não eram tão religiosos, falavam sobre coisas que antes não eram abordadas... isso foi incomodando. Os professores também tinham suas opiniões políticas e como qualquer cidadão comum tinham o direito de debatê-las fora da Faculdade, as discussões aço teciam fora da sala de aula também. Isso foi criando um mal estar e de repente a sociedade, à qual pertence a elite, percebeu que aqueles professores iam criar problemas para ela. Os questionamentos sobre organizações, entidades, voto, incomodava muito." (Profa. Nilce Lodi)

"Pelos jornais nos criticavam, não aceitavam convites para nada, criticavam nossas aulas e até influenciaram o bispo auxiliar de Rio Preto que começou a fazer campanha contra nós. Quando esse bispo soube que eu era católico mandou me chamar ao palácio episcopal para questionar as leituras que eu havia indicado aos alunos, imagine, ele estava uma fera, pois entre os textos estava Voltaire. Naquela época a Igreja ainda tinha o Index de Livros Proibidos e dentre eles 
constavam os textos de muitos filósofos importantes. Agora, como deixar de estudar esses autores tão importantes com meus alunos? Nem pensar!" (Prof. Orestes Nigro)

“Claro que isso deve ter incomodado, e muito, setores mais conservadores da cidade. Imagino que essa convivência tão democrática deva ter sido o fator principal da intervenção militar que ocorreu na cidade em 64. O que não é de se espantar, pois em todos os lugares onde havia movimentos culturais semelhantes aos de Rio Preto deu-se reação semelhante por parte dos militares. Nós aqui em São Paulo, em 64, tivemos o nosso teatro fechado e fomos exilados. Eu mesmo estive na Bolívia com o Guarnieri."(Juca de Oliveira)

"Se você tem uma cidade como Rio Preto, no interior, conservadora, agrícola, ligada à produção de café, à criação de gado, menos industrializada que Ribeirão Preto, e nela surge um movimento cultural de esquerda, muito nítido e atuante, é claro que para os conservadores poderia, quem sabe, haver alguma ligação desse movimento com as Ligas Camponesas, com o Araguaia! Para o delírio deles qualquer coisa servia..."(Juca de Oliveira)

Para refletir sobre a relação entre professores que vieram da USP para a FAFI e a sociedade elitista riopretense, creio que pode-se recorrer ao livro de Norbert Elias e John Scotson “Estabelecidos e Outsiders".

O texto de Elias e Scotson é a respeito de um estudo realizado na comunidade Wiston Parva, na Inglaterra, onde os autores empreenderam uma reflexão teórica que provocou mudanças nos rumos da teoria social contemporânea, sobre os tópicos referentes às desigualdades sociais e das relações de poder delas decorrentes.(MICELI, 2000)

A comunidade de Wiston Parva apresentava no seu interior uma clara divisão. Havia dois grupos: Os "estabelecidos", moradores no local de longa data e 
os "outsiders", um grupo novo de residentes. Sendo assim, nessa comunidade observou-se a situação de "estabelecidos- outsiders". Ou seja, o grupo estabelecido atribuía a seus membros qualidades superiores excluindo os "outsiders" e o controle social era mantido através de fofocas elogiosas ou depreciativas. A peça central dessa figuração é um equilíbrio instável do poder.

A superioridade de forças do grupo "estabelecido" baseava-se no alto grau de coesão de famílias que se conheciam há duas ou três gerações, em contraste com os moradores recém chegados, que eram estranhos não apenas para os antigos residentes como também entre si. Essa falta de coesão era usada para excluir e estigmatizar os "outsiders". "Assim, a exclusão e a estigmatização dos outsiders pelo grupo estabelecido eram armas poderosas para que este último preservasse sua identidade e afirmasse sua superioridade, mantendo os outros no seu lugar".(ELIAS e SCOTSON,2000,p.22)

A partir do livro pode-se encaminhar comentários sobre os acontecimentos em Rio Preto. Os estabelecidos queriam uma universidade, não para mudar, e também não procuravam por educação de ponta. Ela teria três funções específicas: dar créditos na política a alguns de seus "inventores"; proporcionar emprego a um grupo de professores de famílias antigas da cidade e que lecionavam apenas em escolas secundárias; permitir que, principalmente, as moças da sociedade não precisassem sair da proteção da família e se aventurar a cursar a USP em São Paulo.

O governador Jânio Quadros com a institucionalização frustrou tais expectativas. Trouxe para Rio Preto os "outsiders", um grupo de professores que encarava a educação como forma de mudar as relações sociais existentes no país, e que em Rio Preto eram muito bem estabelecidas. Em um primeiro momento tentouse excluir aqueles indivíduos, até mesmo pela execração pública através de jornais.

A peça central de estabelecidos-outsiders é um equilíbrio instável de poder, com as tensões que lhe são inerentes. Um grupo só pode estigmatizar o outro com eficácia se está bem instalado em posição de poder das quais o grupo 
estigmatizado é excluído. Segundo Elias e Scotson, na mecânica da estigmatização é necessário considerar o papel que cada pessoa faz da posição de seu grupo entre outros e de seu próprio status como membro desse grupo. Os membros dos grupos “outsiders" são tidos como não observantes das normas e restrições dos grupos "estabelecidos". A sociedade e os professores de Rio Preto, assim como as instituições públicas, nesse caso o delegado e igreja, uniram-se contra os professores que vieram da USP e que estavam tentando quebrar normas e restrições estabelecidas na cidade.

Os professores da cidade, aqueles que pretendiam um cargo na FAFI faziam parte da elite e achavam que a faculdade deveria ser para eles, auxiliaram os militares, entregando colegas e alunos, pois assim poderiam ficar com os cargos que almejavam.

Outrossim, parece que os professores uspianos não se preocupavam em ser outsiders, em alguns momentos das narrativas isso aparece. Quando eles falam a respeito da escola que queriam implantar em Rio Preto em nenhum momento dizem que procuraram saber que tipo de aluno estudava lá, quem eram seus pais... Se os “estabelecidos" não aceitavam os uspianos, estes não se preocuparam em procurar saber o que aquela população esperava de uma Faculdade. As narrativas sobre como viam o trabalho na faculdade, não mostram a preocupação de serem aceitos pela elite, pelo contrário, eles tinham consciência de seu conhecimento, enquanto a parte da sociedade com mais recursos financeiros era ignorante. O importante era desenvolver uma Faculdade de ponta e eles acreditavam que eram plenamente capazes de fazê-lo.

“Fui para Rio Preto em 1958. Quase todos os professores de lá queriam formar uma escola com características bem brasileiras, queríamos nos livrar dessa coisa européia e buscar as raízes para uma formação brasileira, como pensava o Darcy Ribeiro que a gente conheceu muito, assim como a turma do Ceará... elaboramos, então um plano de escola e convidamos todos que quisessem se agregar. Éramos sonhadores, idealistas. 
Todos os professores da Filosofia, Letras e Pedagogia se agregaram... o Norman, o Orestes, Cantoni, entre outros... o pessoal da Biologia, Zoologia, enfim da História Natural não aceitavam nossas propostas. Começamos a trabalhar cada um no seu setor..." (Profa. Sara Rotenbetg)

"Sabe, o trabalho em Rio Preto era estimulante, professores de nível muito bom querendo criar uma educação diferenciada. O Casimiro Reis Filho, o Orestes, o Azzi, o Cantoni, o Lövy, o Traugtenberg, a Sara, esta última tem uma história a parte, sofreu muito... o Casimiro era espírita... um espírita de esquerda... é até engraçado! Ele era um cara bom, os espíritas são geralmente bons, o que não é o caso dos protestantes, posso falar isso porque minha família é protestante... conheci muitos espíritas bacanas, humanos, generosos." (Prof. Hélio leite de Barros).

“É uma pena que a elite de Rio Preto não pensasse no espírito da Universidade, que é a unidade na diversidade. Ninguém pensou: - Vamos escutar a todos, vamos ver todas as doutrinas... poucas pessoas pensaram assim, e essa elite era culta, esperava-se outra posição.

Enfim, não entendo o que poderia ter provocado esse olhar tão agressivo de desconfiança para Rio Preto. As meninas do nosso grupo eram taxadas de melancia, verdes por fora e vermelhas por dentro. Nosso comportamento ao freqüentar um barzinho que depois virou uma casa de chá chamada "Luar de Agosto", por causa do filme do Marlon Brando, os agredia... achávamos que ficar andando de lá pra cá no footing já era um negócio ultrapassado. Nossos hábitos foram mudando e isso foi visto com muita reserva, afinal estávamos quebrando uma coisa que já estava estruturada... aquela vidinha pacata estava se alterando... era uma sociedade provinciana, cristalizada. Acho 
que quando criaram a Faculdade não pensaram onde ela ia chegar."(Profa. Nilce Lodi)

"Com certeza, as novidades foram criando a desconfiança. A elite se perguntava: “O que será que trouxemos para dentro de casa?" e aí não tinha mais retorno."(Profa. Nilce Lodi)

“O Orestes era uma pessoa muito avançada para sua época, era um professor com tendências socializantes, agindo abertamente dentro da faculdade, aplicando um tipo de ensino diferente, democrático, sempre estimulando os alunos a se inteirarem dos problemas sociais e políticos da cidade, do estado e do país. O professor Orestes não era militante político, não era comunista. Apenas levou a idéia de democracia para dentro da escola, o que fascinou os alunos, que antes eram orientados segundo princípios tradicionais e pouco estimulantes. Era uma loucura! Samba... discussões políticas, teatro político... Violão, saraus! Almoçávamos com os alunos, conversávamos sobre teatro, técnicas de interpretação, Guarnieri falava sobre dramaturgia, sobre autores, Stanislavsky, "A Mandrágora", Maquiavel e eles adoravam." (Juca de Oliveira)

Penso também que a sociedade elitista de Rio Preto cedo se decepcionou com a Faculdade. Que tipo de professores universitários eram aqueles, tão opostos aos catedráticos e mestres que conheciam de outras Faculdades como a USP, por exemplo? Pela descrição de Yara Attab pode-se perceber como esses professores passaram a ser vistos: “A maioria, além de agnóstica, era jovem, descuidada com a aparência e muito agressiva".(ATTAB.1973)

Os professores responderam também, publicamente, aos artigos publicados contra eles. ${ }^{56} \mathrm{O}$ embate se estabeleceu então. De um lado professores e alunos da

\footnotetext{
${ }^{56}$ Ver os artigos no Anexo 3
} 
Pedagogia e Letras, do outro, professores da História Natural, políticos e autoridades de direita, além da elite da sociedade riopretense.

Antes do Golpe, sabe-se hoje, o trabalho de alguns professores vinha sendo observado pelas autoridades de Rio Preto. Sabe-se também que o Golpe Militar vinha sendo gestado desde Getúlio, porém professores da FAFI não esperavam que a intervenção acontecesse em Rio Preto logo no dia $1^{\circ}$. De Abril de 1964, o que não era o caso do Coronel Godói:

“Alguns dias antes do Golpe me chamaram na corporação. Entrei numa sala e lá estavam reunidos vários oficiais, o delegado regional e o coronel. Estavam justamente planejando... eu não diria um ataque...bem, entrarem na Faculdade e prenderem os alunos e professores, era sabido que nos últimos 3 ou 4 meses esses indivíduos haviam se entusiasmado com o Governo Goulart, começaram a fazer comícios, teatro, todos apoiando o caminho que o Goulart estava tomando, esse negócio de reforma agrária, diziam que alguns professores eram comunistas, não sei se eram ou não, mas as coisas estavam fervilhantes..." (Coronel Godói).

Para os professores e estudantes da Letras e Pedagogia a surpresa foi enorme:

“Aí veio a revolução... 1964... Eu lecionava em Ibirá.. 5 ou 6 horas da tarde do dia $1^{\circ}$. De abril fui preso. Fui detido com o Orestes e com a turma toda. Fiquei preso uns 20 e tantos dias... não fui torturado, não aconteceu uma coisa mais grave... houve um período de tensão e aí sai da cadeia." (Edson Guiducci)

“Bem, prenderam todo mundo, depois vieram buscar os professores assistentes para dar depoimento, como eu não me encontrava na Faculdade naquela hora fui até a delegacia depois. Aguardei das 4 até as 7h para ser atendida junto com outros professores assistentes. 
Quando fui ser interrogada, o delegado fazia a pergunta e ele mesmo dava a resposta. Os assistentes não ficaram presos, mas os professores sim, alguns nem voltaram como o Cantoni, ,o Penteado e o Cunha, este último era da História Natural, o único que era diferente dos outros. Ele era carioca, declarava ser do partido comunista... no fim todos os professores que foram presos perderam o emprego."

“Embora fossemos bastante engajados, foi uma surpresa o Golpe. Claro que esperávamos algum tipo de represália, estávamos mexendo muito com a sociedade, mas o Golpe na faculdade ninguém esperava. “ (Prof. Hélio Leite de Barros).

A intervenção foi rápida e certeira. Inicialmente, no dia $1^{\circ}$. De Abril foi aberta uma Sindicância Policial que se transformou em 13 de outubro de 1964 em Processo Crime e posteriormente, em 11 de janeiro de 1967, em Processo Militar, este último enquadra os professores no artigo $9^{\circ}$. e $12^{\circ}$. Da Lei 1802. Tomou posse como diretor da Faculdade um Juiz de Direito da cidade e as denúncias se avolumavam. A intervenção foi vista da seguinte maneira pelo Coronel Godói:

“Agora aqui, como havia só uma faculdade a polícia teve que agir mesmo. Tinha um agitador, o Cunha, esse era um dos mais agitadores... tinha o Orestes, mas esse não era tanto, não se expunha muito... eles agiam dentro da própria sala de aula aconselhando os alunos a fazer isso ou aquilo... o comandante da polícia dessa época era o Eduardo Monteiro, que nós chamávamos de Bitu. Sabe, no ano passado teve um desfile em São Paulo e ele desfilou montado num cavalo. Ele é muito bom, muito consciencioso, não houve violência aqui, não machucaram ninguém, só prenderam e deixaram a policia civil resolver o problema.

“Na civil tinha um delegado chamado Tácito Pinheiro... esse era meio complicadinho, causou toda essa situação política 
aqui, agressões, prisões... as agressões foram causadas pela policia civil, a militar não interveio, não.

Esse negócio de bater na porta de sujeito, tirá-lo de casa, prender, bater, matar, eu sou contra... sei que houve isso no movimento revolucionário, mas não há revolução que não tenha violência de ambas as partes, temos até o caso de um tenente que foi mandado para prender um grupo de terroristas que estava no Vale do Ribeira com o Lamarca... quando os terroristas conseguiram pegar os militares, esse tenente propôs um acordo, pediu para soltar os companheiros que ele ficava de refém, eles soltaram, mas o que fizeram com o coitado... as maiores barbaridades, mataram ele aos poucos, castraram o pobre..."(Coronel Godói)

Professores e alunos presos têm outra visão:

" O pessoal de direita, que nem de direita podemos chamar porque eles não eram nada, foram apenas oportunistas, se reuniu e aproveitou a oportunidade, o Daud era o principal denunciante e já ates do golpe vinha se reunindo com o Tácito Pinheiro Machado, um delegado geral da cidade que foi uma figura fundamental na invasão, ele estava macomunado com o juiz Duarte, que "coincidentemente" foi ser o diretor da faculdade... bem feito para o Daud que queria ocupar esse cargo.Havia uma aluna, Yvone de Moura Campos que também denunciou os professores e colegas... tudo por despeito. Ela era medíocre." (Prof. Hélio Leite de Barros)

"Até hoje não entendo esse medo da sociedade, dos militares... talvez fossem as idéias, o manifesto dos professores em defesa da escola pública...esse manifesto foi muito divulgado e talvez tenha chamado a atenção.

Não sei, pode ser que alguém da elite ou professores descontentes possam ter procurado alguém, mas não sei, houve 
até uma disputa entre um professor que depois veio a ser nosso diretor, o Antonio Bento Coelho, ele não era professor na Faculdade na época, mas pegou um gancho num artigo do Casemiro e começou um debate, ou melhor, uma briga. Eu já era assistente do Casemiro e disse a ele que não gostava dessas brigas pelo jornal. Além do mais, era uma discusão absurda, como o Casemiro podia ser comunista se ele era espírita "roxo". Eu sou católica e ele sempre me respeitou... uma discussão sem sentido, ele era um homem voltado para o ser humano e pra Deus. As pessoas nem sabiam o que era comunismo." (Profa. Nilce Lodi)

“Quando fui presa, meu pai que era político e tinha seus contatos não me deixou ficar muito tempo na cadeia. Repito, não fiquei traumatizada por ter sido presa, meu trauma foi ver que nós tínhamos um negócio tão bem feito para mudar o mundo radicalmente, um modelo tão especial, não ter dado certo. $\mathrm{O}$ diretor que assumiu a faculdade, um tal de José Duarte conhecido como "carrasco da Ilha Grande", ajudou a repressão, ajudou entregar todo mundo, nem pensou nos alunos. Horas depois do Golpe os interventores estavam lá em Rio Preto, não tinha militar, mas quem estava lá, estava a mando dos militares. A própria cidade não nos apoiou, achavam bom, para eles nós sempre fomos alienígenas. Teve uma colega, a Yvone Mourão, que denunciava todo mundo, o Professor Daud... essas pessoas nem me conheciam direito e me denunciaram... denunciaram professores... eles queriam o lugar deles na faculdade... tanto que depois o Daud virou professor e a Yvone também... acho que se aposentou na UNESP.Era pura inveja! Além da inveja, tinha o delegado Tácito de Pinheiro Machado, que queria fazer carreira... até entendo o lado do Daud e do Tácito, mas a Yvone... uma aluna, que teve professores como aqueles da USP, ser reacionária... não entendo. 
O nome que dou para aquele acontecimento de 64 é Golpe. Foi um Golpe mesmo... diziam que o país estava sendo invadido por comunistas, uma grande desculpa, o que eles queriam era tomar o poder... “(Maria de Lourdes Cápua)

“Então aconteceu a Revolução de 31 de março. Pouco tempo antes, em janeiro de 1964, eu havia ido numa reunião da UEE (União Estadual dos Estudantes) na região de Campinas e em meados de fevereiro fui à São Paulo num encontro na Praça da Sé e quando estávamos chegando lá encontramos a polícia. Houve tiros, confusão e o grupinho de Rio Preto de dispersou. Voltamos para Rio Preto, demoramos 2 ou 3 dias para chegar, ficamos com receio...aí veio a Revolução e ficamos com receio de falar sobre esses acontecimentos dentro da Universidade, ficou um clima meio de pânico lá. Alguns dias depois um policial civil bateu na minha porta... eu não estava em casa, então no outro dia fui falar com o delegado, o Doutor Mariano. Perguntei o porquê da ida do policial à minha casa, não havia matado ninguém. $O$ delegado disse que era um jovem líder, instigador de jovens. Fui liberado, mas no outro dia a polícia veio com uma viatura e fui preso. Não fui nem para o presídio, fiquei na cadeia mesmo e lá estava também o Pedro Bonilha. Ficamos presos na delegacia cerca de uma semana, de lá nos transferiram para a cadeia perto do cemitério. Só tinha preso político e ficaram ameaçando de nos mandar para São Paulo."(Grigor Vartanian)

“O desenvolvimento e as inovações curriculares que estavam sendo processadas foram, abruptamente, interrompidas pelo Golpe Militar de 1964, em que a repressão iniciada à nível nacional, foi arbitrariamente executada pela autoridade local. Em Rio Preto, por exemplo, o delegado aceitava denúncias anônimas, levando-o a aprisionar inicialmente membros do corpo docente, e, mais tarde, do discente. 
Dessa perseguição, em parte anticomunista, em parte simplesmente ressentimento local contra uma Faculdade repleta de "bárbaros" da Capital, resultou a demissão de vários colegas e do desmembramento do departamento de Pedagogia.

...depois da Revolução de 64 fui para a Venezuela trabalhar numa escola rural... quando voltei foi que fizemos Direito em Uberlândia... nunca ninguém soube lá que eu já era professora universitária...

Havia um pessoal de direita lá em Rio Preto, um delegado que era um... um grupo do contra...tinha sido tão difícil o Goulart se tornar presidente e olhe que ele cercou-se de pessoas muito capazes, o Almino Afonso que era um grande pensador, o Paulo Freire... eram pessoas que como nós queriam mudar o Brasil, a Reforma Agrária que já estava sendo aplicada em toda a América Latina, mas ainda era incipiente no Brasil... o Estatuto da Terra que era super importante... a entourage do João Goulart era... era a mudança... era o desejo de igualdade...

Agora, como quebrar uma hierarquia militar, uma estrutura tão enraizada? Só se quebra com uma revolução, aí se quebra o pensamento e o pensamento é o estímulo para poder fazer... infelizmente não estávamos preparados...os estudantes queriam, nós queríamos uma maneira mais igual de viver, de estudar...A Universidade estava querendo que todos tivessem oportunidades, a formação que dávamos formava pessoas altamente gabaritadas e sers pensantes... só que nem todos pensavam assim e feriu-se a Constituição.... nós tínhamos que reagir... porém, dentro da faculdade ninguém conversava com ninguém, sabíamos que as paredes tinham ouvidos... conversávamos com os gestos, os olhos... havia tantos dedosduros... começou de fora e entrou na Faculdade... o turco Daud era terrível, pessoas não formadas queriam tomar a faculdade 
só porque tinham ajudado a fundá-la, claro que em benefício próprio..."(Profa. Sara Rottenberg)

"Sei que da FAFI, alguns poucos professores, lembrome do Orestes Nigro e do Eduardo Cañizal, e talvez uma dúzia de estudantes ficaram presos, mas não na prisão comum, mas num edifício administrativo contíguo a esta, de construção recente e que não estava sequer mobiliado. Passávamos os dias a fazer música, jogar cartas e dominó, mas com poucas leituras e conversas sérias. A alimentação era assegurada por familiares e amigos que a vinham trazer, e como os guardas não levavam suas funções muito a sério ("Os senhores ainda vão ser nomes de ruas em Rio Preto", disse um deles), ficávamos sabendo o que se passava lá fora, e tivemos a possibilidade de transmitir recados e até de enviar cartas.

Houve alguns interrogatórios por um delegado, perfeitamente educado e até entediado, no sentido de já ter se convencido de que eram absurdas as acusações que corriam pela cidade e que nos imputavam, isto é que estaríamos preparando uma intentona comunista armada, afirmando a rádio local que no sótão da minha casa tinha sido encontrado um depósito de armas...

Durante toda esta fase, o único ato de intimidação que houve foi um dia de prisão solitária que passei a mando de um sub-delegado que "não ia com a minha cara", e cuja ordem foi logo anulada. Não houve qualquer tortura, nem ameaça de tortura. Fui transferido para o DOPS, provavelmente, porque havia uma idéia fantasmagórica de eu ser um agente internacional comunista; a transferência fez-se numa viatura da polícia, com o tal sub-delegado à paisana e dois policiais fardados, os quais estavam visivelmente constrangidos com a encenação toda e até me pagaram uma bebida numa parada..."(Prof. Franz Heimer) 
"Claro que não havia nada de subversivo ou de guerrilha na faculdade. Foi uma esquizofrenia, uma psicose, uma loucura o que aconteceu. Não existia nenhum movimento organizado na Faculdade para subverter a sociedade"(Juca de Oliveira)

“Aí veio a Revolução! Fui acusado de ser comunista. Nunca li Marx e nem tenho intenção de ler. Nunca fui teórico. Para mim política é um negócio que corre na pele. Quando fui preso e o delegado perguntou se eu era comunista eu disse a ele que não sabia bem o que era. Falei que politicamente não era, pois não pertencia ao partido e nunca havia lido nada sobre isso, nem que eu quisesse ser comunista poderia afirmar isso, para ser comunista tem que se conhecer a teoria, os manifestos e eu não conhecia. Disse a ele : o que sou doutor é um inconformista e dessa maneira sou capaz de fazer coisas piores que os comunistas. Se souber de alguém que está explorando, escravizando as pessoas o senhor me dá uma arma que vou lá e mato. O senhor quer colocar aí que sou perigoso, coloque, agora comunista não sou." (Pof. Orestes Nigro)

“Durante todo o processo diziam que o Cantoni era comunista, que comunista que nada, ele era fabuloso, mas o sistema não tinha alcance para entender isso. A própria policia de Rio Preto não sabia o que estava fazendo. O Heimer deu um baile no delegado que perguntou a ele se ele se considerava subversivo. Ele pediu ao delegado que definisse subversão. $O$ delegado não soube fazê-lo e o Heimer disse que ele estava falando besteira, isso lhe valeu muita pancada. O Heimer foi o único que apanhou lá, muito. Ele enfrentava a policia e daqui acabou indo para o Chile, depois com o Pinochet... deve ter voltado para a Alemanha."(Prof. Orestes Nigro)

“Depois que saí da cadeia quase fui preso novamente porque resolvi ir até a Faculdade buscar minhas coisas. Assim que cheguei lá foi uma choradeira, alunos me abraçando... e aí 
aconteceu uma coisa muito triste. Havia um funcionário que eu levei para a faculdade, pois ele era motorista de táxi e estava passando por dificuldades... arrumei emprego para todos os filhos dele, pois bem, assim que me viu na faculdade chamou uma verdadeira "Rota", que me levou para a sala do novo diretor, que era um Juíz de Direito chamado José de Castro Duarte, conhecido como "O Carrasco da Ilha Grande". Na sala ficaram o Aristides, os policiais e o diretor que começou a gritar comigo dizendo que eu havia sido demitido para desinfetar a faculdade, que não aparecesse mais lá... eu disse que não havia recebido nenhuma restrição de movimentos, que apenas havia ido buscar minhas coisas... lá havia muitas coisas, livros, jornais franceses que eu assinava, toda minha vida profissional. Ele respondeu que no sábado próximo enviaria tudo para minha casa, que eu não pisasse mais lá, se isto acontecesse seria preso e enviado para o Deops em São Paulo e o Aristides assistindo tudo, não moveu um dedo... “(Orestes Nigro).

A maioria das pessoas que foram presas mostra decepção com os rumos da escola hoje. Muitos mostram nas narrativas um anseio utópico na realização de sonhos que foram considerados possíveis e não se realizaram. Essa perspectiva implica compreender que o momento atual não é o desejado e remete a uma proposta utópica, de fato, quando buscam o ideal num passado desaparecido, as utopias levam consigo a marca do tempo. Utopias são "respostas não somente a perguntas sobre a condição humana mas ao que não foi e poderia ter sido".(SZACHI.1972)

Quando nossos colaboradores falam do que foi e do que poderia ter sido a Faculdade a mágoa está quase sempre presente, assim como a desilusão e o sentimento de impotência. A educação, hoje, para eles é péssima.

“Eu fui demitido num segundo grupo por não ter completado a minha tese de doutoramento. Poderia ter entrado com um requerimento pedindo mais prazo para completá-la, 
pois era impossível trabalhar numa tese num clima tão instável. Estava, no entanto, tão deprimido pelas demissões e prisões dos meus colegas e pela destruição de tudo que estávamos tentando criar em nosso departamento. Por isto, resolvi sair do país e procurar trabalho aqui, nos Estados Unidos." (Prof. Anoar Aiex)

“Rio Preto foi a primeira faculdade que sofreu intervenção e creio que isso aconteceu porque eles mediram nossa qualidade... não era interessante para eles... formávamos acadêmicos pensantes e isso não era interessante para a direita, não éramos uma escola clássica com formação clássica, estávamos muito a frente de nosso tempo, não formávamos aberrações acadêmicas como essas que estão por ai. Não basta saber ler e escrever... tem que saber pensar, criticar, agir e isso nos fez servir de vidraça... os medíocres tinham ódio de nós. Depois de nós veio a mediocridade como o Zeferino Vaz (Nhá Zefa) lá da PUC que andava com a braguilha aberta... Rio Preto não estava preparada, não haviam classes sociais lá, só uma elite e é assim até hoje." (Profa. Sara Rottenberg)

“...tínhamos certeza de que íamos ser grandes... de repente... caiu tudo por terra. Acho que esses professores tinham um grande projeto... até hoje quando encontro um colega daqueles tempos ouço: -Ah que saudade! Foi uma coisa que marcou todo mundo.

Nós tínhamos formação política... Cho que ia além da política, era ideológica... era uma vontade que o Brasil desse certo, que progredisse.. e a revolução podou todo mundo.

A educação é uma decepção... o aluno hoje é um estranho... falei para a Neli, minha mulher, que embora tenha capacidade, era hora de me aposentar.. nãoo tenho mais acesso ao aluno... a escola está indo do jeito que Deus dará, vejo isso com muita tristeza, leio jornais, não se cobra nada, não existe um plano definido... sou muito pessimista em relação ao futuro que nos espera... não vamos ter mais bons profissionais, nem de nível 
médio capazes de movimentar uma máquina, de produzir qualquer coisa... simplesmente virou uma bandalheira...isso é o que tenho visto em sala de aula. Hoje você está dando aula e o aluno está mandando torpedo para os outros, você não pode fazer nada, se fizer a direção chama sua atenção... alunos agridem professores e a diretora não faz nada... eu estou totalmente descrente... sempre dei aulas em escolas boas... na UNB, no Colégio Objetivo de Brasília, no Seta, aqui em Rio Preto, escolas de alto nível, mas está tudo igual... um caos."(Edson Guiducci)

“Uma pena que a educação hoje esteja desse jeito... foi decaindo...decaindo...as turmas na faculdade cada vez mais apáticas, alguns alunos ainda bons e era por esses que os professores eram estimulados... e a coisa continuou caindo numa queda cada vez maior.

Acho que ainda há possibilidade de melhora, de sair do buraco, existem profissionais sérios, comprometidos com a educação e as coisas estão mais fáceis, os tabus vão sendo derrubados." (Profa. Nilce Lodi)

“Bem, depois do Golpe voltei para a faculdade e aí, a única coisa que eu queria era terminar o curso o mais rápido possível, doía ter aulas com o Coelho, um professor medíocre, depois de ter tido grandes mestres."(Maria de Lourdes Cápua)

As razões para o Golpe ainda não são claras para alguns colaboradores, que tentam durante a narrativa encontrar justificativas para tal fato:

“Até hoje não entendo esse medo da sociedade, dos militares... talvez fossem as idéias, o manifesto dos professores em defesa da escola pública...esse manifesto foi muito divulgado e talvez tenha chamado a atenção.

Não sei, pode ser que alguém da elite ou professores descontentes possam ter procurado alguém, mas não sei, houve até 
uma disputa entre um professor que depois veio a ser nosso diretor, o Antonio Bento Coelho, ele não era professor na Faculdade na época, mas pegou um gancho num artigo do Casemiro e começou um debate, ou melhor, uma briga."(Profa. Nilce Lodi)

Já o Prof. Orestes Nigro tem uma explicação bastante objetiva para o acontecimento do dia $1^{\circ}$. De Abril de 1964:

“Penso que as mais prováveis causas de nós termos sido as primeiras vitimas foram que Rio Preto era na época um baluarte da direita reacionária brasileira, tanto assim que ganhara o apelido de Dallas paulista, lembre-se do assassinato de Kennedy. Era também uma cidade geograficamente estratégica para mais fácil acesso às fronteiras de Minas Gerais, Goiás e Mato Grosso, como foram os militares que preparam o Golpe de 64... para completar Rio Preto tinha na época as autoridades mais reacionárias do Brasil, prefeito Loft Bassit, juiz da comarca José de Castro Duarte, e um delegado regional de polícia ambicioso demais em termos de carreira, Tácito Pinheiro Machado, que deitou e rolou durante a primeira fase repressora e como prêmio tornou-se Delegado Geral de Policia, segundo cargo mais importante na hierarquia da Secretaria de Segurança Pública. Enquanto nas outras cidades da região as autoridades discutiam para depois prender, Tácito primeiro prendia, para depois discutir. Por isto logo no dia $1^{\circ}$ de abril de 64, a cadeia de Rio Preto estava cheia de presos políticos."

A partir das narrativas percebemos como se formaram dois grupos antagônicos na faculdade, aqueles da cidade que se julgavam habilitados para compor o corpo docente da faculdade, que haviam nascido em Rio Preto, uma cidade pioneira até na construção de uma faculdade e o outro, professores universitários, segundo a visão da elite, tão contrários ao que eles esperavam de catedráticos e mestres. As ideologias de cada um deles e como suas memórias foram construindo suas identidades. Todos os professores fizeram questão de dizer que eram formados pela USP, que depois, quando foram afastados e presos a qualidade do ensino caiu. 
Os alunos entrevistados apresentaram o mesmo argumento. Para a maioria desse grupo de pessoas que entrevistei, o que existe é a FAFI e não a UNESP.

$\mathrm{Na}$ fala dos colaboradores ditos revolucionários está sempre presente a frustração e o trauma de ver um projeto educacional tão bom ser desfeito . Muitos choraram... mesmo após mais de 40 anos. 
PARTE VI

Venha ver, desta república

Crianças na cadeia pública

Em farrapos e a cor faminta

Venha, e creia que eu não minta,

Ver, desta geringonça

Famílias buscar abrigo

Atrás do "Mário Alves Mendonça"

Isto mesmo, atrás do campo do América.

(Desova Poética/Orestes Nigro) 


\section{CONSIDERAÇÕES FINAIS}

No início dos anos 1960 no acirramento das lutas políticas e da mobilização nacional, houve a articulação de vários movimentos sociais que se envolveram em diversas campanhas de caráter político e social. Havia reivindicações, no contexto educacional brasileiro, de uma reforma universitária, uma vez que para docentes e discentes das universidades brasileiras, esta refletia os problemas sociais da realidade nacional. Em São José do Rio Preto havia uma Faculdade criada em 1955 que congregava naquele momento diversosgrupos de movimentos sociais .

A Faculdade de Filosofia, Ciências e Letras de São José do Rio Preto surgiu em decorrência da expectativa que havia nos anos 50 em torno da possibilidade de expansão do ensino superior no interior do Estado. No caso de Rio Preto, a comunidade local desenvolveu ampla campanha, apoiada pela imprensa, em torno da criação de uma universidade. Esses esforços foram contemplados a 25 de maio de 1955 com a Lei Municipal que criou uma Universidade para Rio Preto tendo como sua primeira unidade universitária uma Faculdade de Filosofia, Ciências e Letras. Esse ato, emanado do poder público municipal, contou com a concordância das autoridades educacionais do Estado de São Paulo que prestigiaram, com sua presença, a posse solene do Conselho Geral e da Diretoria Executiva da Universidade ocorrido a 20 de agosto de 1955.

Essa faculdade,assim como outras do interior, as chamadas isoladas, pela própria formação e por uma qualificação precisa adotadas, foram marcadas por uma identidade entre a docência e a pesquisa na compreensão da necessidade da busca de aprimoramento acadêmico. Associada a essa característica, essas escolas estiveram fundamentadas no tripé que identifica a instituição acadêmica - a docência, a pesquisa e a extensão de serviços à comunidade. Essas instituições, que foram pioneiras na implantação do ensino superior público de qualidade no interior do Estado de São Paulo, ficaram, desde sua criação, sob a administração da Secretaria de Educação do Estado de São Paulo. 
Desde sua criação essas faculdades eram tidas como instrumentos de preparação de quadros para exercer os papéis e funções necessárias ao desenvolvimento e assegurar a ideologia dominante. Segundo Maria de Lurdes Fávero, os grupos dirigentes do país têm, nesse momento, a convicção de que escola (universidade) é um veículo privilegiado para o inculcamento e a preservação de sua ideologia.

A universidade foi concebida para veicular a ideologia dominante, quando as idéias progressistas tomam forma ou ameaçam romper este canal, para garantir o controle, entra em ação o autoritarismo. Por isso, diz Antonio Muniz de Rezende, "sabemos todos que na história da universidade brasileira houve sempre uma tendência nítida ao autoritarismo centralizador" (1987, p. 10), quer seja oriunda de seu interior ou do exterior.

Em Rio Preto, porém, o grupo de professores contratados para lecionar nessa instituição, não só trazia o desejo de mudar a sociedade, como de transformar a educação. Embora muitos desses professores declarassem não pertencer a nenhuma ideologia, seja de esquerda ou direita, entre eles, com certeza havia o desejo de uma revolução. A carta abaixo, enviada a Profa. Maria Edith Gamborgini por seu colega Jamil Almansur Hadad, da China, demonstra como a educação era pensada então: 
204

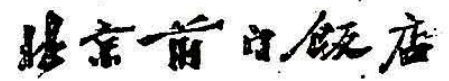

Mana Folite

Devor parte do mundo fat Salva snvio-the. as min has sauda tóes 't as Flavio eor men votos para fue tiânsile peín poetas mincrios, durate o den curs. ine whe sende atrairivel. Af wat di contas a yrconfidencic Tambin té Rewhios.

Rcomende-me ais tolegas e aos alunos.

- tanbeir as alunas.

Peguin, 27 di Detembro \& 19621

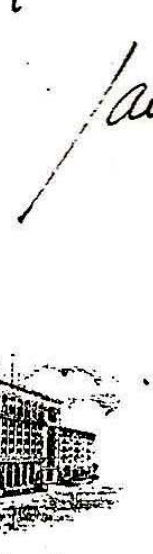


Pensava-se em erradicar definitivamente o analfabetismo através de um programa nacional, levando-se em conta as diferenças sociais, econômicas e culturais de cada região. Em Rio Preto professores e alunos organizavam-se para alfabetizar adultos, conscientizar trabalhadores através do teatro e das artes como um todo. Havia uma nova proposta para a universidade, a esperança de justiça social e cultura era o que movia tais indivíduos. Era a revolução pela educação. Em nenhum momento levou-se em questão que as transformações propostas por eles poderiam não agradar a elite local.

O período anterior, de 1946 ao princípio do ano de 1964, talvez tenha sido o mais fértil da história da educação brasileira. Neste período atuaram educadores que deixaram seus nomes na história da educação por suas realizações. Professores como Anísio Teixeira, Fernando de Azevedo, Lourenço Filho, Carneiro Leão, Armando Hildebrand, Pachoal Leme, Paulo Freire, Lauro de Oliveira Lima, Durmeval Trigueiro, entre outros. Os que estavam em Rio Preto não foram menos importantes nem menos capazes. Mauricio Traugtenberg, Orestes Nigro, Hélio Leite de Barros, Anoar Aiex, Orestes Nigro, Sara Rottenberg, entre outros estavam preparados para formar seres humanos esclarecidos, justos de conscientes de seu papel social.

Havia uma mobilização nacionalista no interior daquela Faculdade e a cultura era encarada como um instrumento de transformação social e andou junto com a política durante as décadas de 1950 e até o ano de 1964. A idéia da educação pela cultura e a transformação que isso traria foi tão importante que em 1963, no I Encontro de Alfabetização no Recife, compareceram 77 grupos de movimentos sociais.(PAES. 1997)

A ditadura militar atingiu diretamente as universidades, impondo uma severa intervenção e repressão. Muitos intelectuais foram perseguidos, exonerados, aposentados compulsoriamente e exilados. Dentre as universidades que foram atingidas mais diretamente pelo regime militar encontram-se a USP, UNICAMP, UNIESP, FGV, UFMG e a FAFI. Na FAFI, por exemplo, funcionários foram demitidos, diretores das unidades foram exonerados e nomeados interventores. $\mathrm{Na}$ 
verdade a FAFI foi a primeira instituição a sofrer intervenção, no dia $1^{\circ}$. De abril de 1964.

Percebe-se, nas narrativas, a importância estratégica de São José do Rio Preto. A cidade se localiza nas fronteiras entre os Estados de São Paulo, Minas Gerais e Mato Grosso.

Outrossim, a sociedade riopretense, composta por uma elite que possuía em seu bojo a maioria dos grandes cafeicultores da região, sentia-se incomodada com a "modernidade" trazida pelos professores de São Paulo e pelas iniciativas de alfabetização e conscientização do povo proposta por eles.

A intervenção se deu na faculdade porque ela possuía, nos cursos de Letras, Pedagogia e Filosofia, um corpo docente profundamente ligado aos problemas sociais da região, aí se incluindo a questão dos camponeses e operários. Esses professores em conjunto com os alunos implantaram na Faculdade, além de grupo de teatro, MPC, Centro Acadêmico, todos muito atuantes, um tipo de ensino muito diferente do tradicional .

A Faculdade foi fundada em São José do Rio Preto por uma elite que queria ocupar cargos na mesma e esse desejo não foi respeitado pelo governador Jânio Quadros, que por ocasião da estadualização da faculdade, exigiu um corpo docente que houvesse sido formado pela USP.

O ensino na Faculdade de São José do Rio Preto era inédito, lá os alunos, além de aprender as disciplinas inerentes à cada curso, também se envolveram nos problemas sociais, assim como os professores. A maioria deles era de esquerda e conscientizada dos problemas que assolavam o país. Apoiavam claramente o governo do Presidente João Goulart. Poderíamos afirmar que um aluno formado na Fafi sabia "pensar". A faculdade de São José do Rio Preto vinha sendo vista como um modelo a ser seguido pela educação no Brasil e isso fez com que os militares, no primeiro momento após o Golpe, interviessem na Faculdade, de maneira a acabar com esse tipo de educação, que era contestadora, para implantar seu próprio sistema 
de ensino, que não deveria formar pessoas tão esclarecidas que pudessem de alguma maneira enfrentá-los.

Os professores da cidade, aqueles que pretendiam um cargo na FAFI, faziam parte da elite e achavam que a faculdade deveria ser para eles, auxiliaram os militares, entregando colegas e alunos, pois assim poderiam ficar com os cargos que almejavam.

Os professores e alunos que foram presos na intervenção ficaram, na época, com sentimentos de incredulidade, impotência e injustiça. Hoje, esses sentimentos permanecem, acrescidos da tristeza por saberem que o tipo de educação que propunham poderia ter resolvido inúmeros problemas sociais com os quais o Brasil se depara hoje e ao perceber a educação brasileira classificada entre as piores do mundo. Eles têm certeza da excelência do projeto educacional que pretendiam e começaram a desenvolver desde 1957.

Com o Golpe Militar de 1964 as idéias desses profissionais foram eliminadas. Assim se fez silenciar o ideal de expressão artística como denunciadora e transformadora das injustiças sociais.

Durante a intervenção, foram presos os alunos: Pedro Bonilha; Edson Guiducci; Edson Raposeiro; Grigor Vartanian; Murilo Farinazzo; Ari Neves; Rui Quirino Guimarães; Nilo Sérgio Scrochio; Vladimir Moscheta; Mara Jorge Ramos; Eudete Fochi e Maria de Lourdes Cápua; Aparecida Barbo Soler; Lederci Gigante, João Paulo de O. Neto.

Os seguintes professores foram demitidos sumariamente: Mauricio Tragtenberg; Wilson Cantoni; João Jorge da Cunha; José de Arruda Penteado; Sara Rottemberg; Orestes Nigro; Norman Maurice Potter; Joacir Badaró; Newton Ramos de Oliveira; Maria Edith do Amaral Garboginni; Franz Wilhein Heimer; Flávio Vespasiano Di Giorgi; Casemiro dos Reis Filho; Hélio Leite de Barros; Jacb Lebenzteyn; Mary Amazonas Leite de Barros; Jorge de Senna. 
Foram indiciados: Maria de Lourdes Heimer; Prof. Franz Wilhein Heimer; Lederci Gigante; Prof. Flávio Vespasiano Di Giorgi, Profa.Maria Edith do Amaral Garboggini; Prof. Orestes Nigro; Prof. Hélio Leite de Barros; Profa. Mary Amazonas Leite de Barros; Prof. Newton Ramos de Oliveira; Prof. João Jorge da Cunha.

Foram denunciados: Prof. Franz Wilhein Heimer; Maria de Lourdes Heimer, esposa do Prof. Heimer; Lederci Gigante, aluna; Prof. Flávio Vespasiani Di Giorgi; Prof. Orestes Nigro; Prof. Hélio Leite de Barros; Mary Amazonas Leite de Barros, Prof. Newton Ramos de Oliveira e Wilson Cantoni.

Após a intervenção, a doutrina da segurança nacional se instalou na Faculdade de Rio Preto. Listas de Professores foram fornecidas às autoridades policiais, professores simpatizantes do Golpe foram contratados para substituir os que tinham sido cassados. Era o início do caminho para a transformação da FAFI em UNESP. 


\section{FONTES ESCRITAS}

Processo da Justiça Militar do $1^{\circ}$ Distrito Naval da $4^{\mathrm{a}}$ Zona Aérea contra o acusado Franz Wilhein Heimer e outros contendo autos de apreensão, depoimentos, fichas policiais, denúncias oferecidas pelo ministério público, depoimentos de acusação, atas de fundação do GRUTA e do MPC , documentação que comprova a criação de um Sindicato no Nordeste financiado pelos alemães, cartas solicitando espaços em fábricas para apresentação de peças de teatro, listas de funcionários que trabalhavam na Faculdade Isolada em 1964, cartas convocando o povo para a luta contra a opressão, enfim toda documentação do processo acima citado.

Correspondência dos professores com amigos, colegas e autoridades.

Planos de aula, apostilas, material de alfabetização de adulto baseado no método Paulo Freire adaptado para os camponeses da região.

Artigos de jornais da época, todos da região de São José do Rio Preto.

Peças de teatro

Letras de música - paródias

Fotografias.

\section{FONTES ORAIS}

Entrevistas com professores, alunos, funcionários e outros. 


\section{BIBLIOGRAFIA}

ALVES, M.H.M (1984). “Estado e oposição no Brasil” (1964-1984)”, Vozes, Petrópolis.

AGOLO,J; RIBEIRO,K;FORTUNATO L. (1996) “A direita explosiva no Brasil”.Editora Mauad, Rio de Janeiro.

ASSOCIAÇÃO dos docentes da USP (1978) “O Livro Negro da USP”, São Paulo.

BAFFA,A. (1989) "Nos porões do SNI: o retrato do monstro de cabeça oca", Editora Objetiva, Rio de Janeiro.

BARREIRO,I.F.M. (1994) “Educação modernizadora e educação de classe: o lazer, a cultura popular e o trabalho no período de Vargas a Juscelino". In Revista Brasileira de História v.27 p. 149. Editora Marco Zero. São Paulo

BAUMAN, Z. “Identidade.(2004) Jorge Zahar Editor, Rio de Janeiro.

BERGER, M. (1976) “Educação e Dependência”, Editora Difel - UFRS , Porto Alegre.

BEAR, M.F.; CONNORS, Barry W. e PARADISO, Michael (1996) “Neuroscience: Exploring the Brain." in: Memory Systems, pp514 a 545. Editora Lipincott,Williams \& Wilkins, Londres.

BLOCH, M.(2002) "Apologia da História ou O Ofício do Historiador",Jorge Zahar Editor, Rio de Janeiro

BURKE, P. (1999) “A escrita da História".Jorge Zahar Editor. Rio de Janeiro.

(2003) "Uma história social do conhecimento".Jorge Zahar Editor. Rio de Janeiro (1989) "Cultura popular na idade moderna". Companhia das Letras, São Paulo. 
BOAL, A. (2005) "O Teatro dos Oprimidos: e Outras Políticas",Editora Civilização Brasileira. Rio de Janeiro.

(1885) “Teatro de Augusto Boal II", Hucitec, São Paulo.

BOSI, A. (2003) “Cultura Brasileira, temas e situações", Editora Ática , São Paulo.

BOSI, E. (2004) "O Tempo Vivo da Memória", 2a . edição, Ateliê Editorial, Cotia (1995) "Memória e Sociedade lembranças de velhos" 13a . edição, Cia. das Letras, São Paulo.

BRAUDEL, F. (1972) "História e Ciências Sociais", Presença, Lisboa.

CANCLINI, N.G.(2003) “Culturas híbridas: estratégias para entrar e sair da modernidade." Cia das Letras. São Paulo.

CANTONI, W. (1964) "Uma experiência de Reforma Universitária", Edições Faculdade de Filosofia, Ciências e Letras de São José do Rio Preto, São José do Rio Preto.

CARVALHO, J.M. (2005) "Forças Armadas e Politica no Brasil", Zahar, Rio de Janeiro.

CHAUİ, M. (1998) “ O que é ideologia?”, Editora Brasiliense, São Paulo.

(1988) "Conformismo e resistência, aspectos da cultura popular no Brasil," Editora Brasiliense, São Paulo.

CORBISIER, R. "Formação e problema da cultura brasileira."(1958), ISEB, 88p. (Textos Brasileiros de Filosofia, 3), Rio de Janeiro.

CORREA.A.M.M.(org.)(2006) “Unesp 30 anos: Memórias e Perspectivas. CEDEM/Editora UNESP. São Paulo.

CUNHA, L.A. \& GÓES, M. (1985), "O golpe na Educação", Editora Zahar, Rio de Janeiro.

CUNHA, L.A. "A profissionalização do Ensino Médio"(1977)EditoraEldorado, Rio de Janeiro. 
D'ARAUJO, M.C., org. (2004), SOARES, G.A.S. CASTRO,C."Visões do golpe - A Memória Militar de 64" ,Ediouro, Rio de Janeiro.

DELGADO, L.A.N. (2006), "História Oral, Memória , Tempo , Identidades" Autentica Editora, Belo Horizonte.

DREYFUSS. R.A. (1981). “1964: A Conquista do Estado- Ação Política, Poder e Golpe de Classe." Editora Vozes. São Paulo.

ELIAS,N; SCOTSON,J. (2000) “Os estabelecidos e os outsiders: sociologia das relações de poder a partir de uma pequena comunidade". Rio de Janeiro, WVA.

FÁVERO, M.L.A. (1999), " A Une em Tempos de Autoritarismo", Editora UFRJ, Rio de Janeiro. (2000), “A Universidade no Brasil: das Origens à Reforma de 1968" Editora UFPR, Curitiba.

FÁVERO, O.(1996) “ A Educação nas Constituintes Brasileiras 1823-1988".Editora Cortez, Campinas.

FELICIO,V.L.(1996) “ A Procura da Lucidez m Artaud". Editora Perpectiva, São Paulo. FERNANDES, F. (1975) "Universidade Brasileira: Reforma ou Revolução?" Editora AlfaOmega, São Paulo.

FERREIRA, M.M.; AMADO, J. org. (2006) "Usos e Abusos da História Oral”, 8a . edição, Fundação Getúlio Vargas Editora, Rio de Janeiro.

FICO, C. (2004) “Além do Golpe", Editora Record, Rio de Janeiro, São Paulo.

GARCIA,M. (2004) “A questão da cultura popular: as politicas culturais do Centro Popular de Cultura(CPC) da União Nacional dos Estudantes(UNE)" in Revista Brasileira de História. ANPUH/CNPQ. São Paulo

GASPARI, É. (2002) "A Ditadura Escancarada""A Ditadura Envergonhada",Cia das Letras, São Paulo. 
(2003) “A Ditadura Derrotada", Cia. da Letras, São Paulo.

(2004) "A Ditadura Encurrulada", Cia. das Letras, São Paulo.

GERMANO, J.W. (1994) “Estado Militar e Educação no Brasil (1964-1985)”. Editora

Cortez, São Paulo

GÓES, M.; CUNHA, L.A.(1999) "O Golpe na Educação", 11a. edição, Jorge Zahar Editor.

GORENDER, J. (1999) “Combate nas Trevas", Ática , São Paulo

HALBWACHS, M. (2006) “A Memória Coletiva”, Centauro Editora, São Paulo.

HOLLANDA, H.B.; GONÇALVES, M.A. (1982) "Cultura e Participação nos anos 60". Editora Brasiliense. São Paulo.

HOLLANDA, H.B. (org.) (1992) "Pós-Modernismo e Política". Editora Roço. Rio de Janeiro.

LAMBERT,J.(1969) "Os Dois Brasis".Coleção Cultura, Sociedade e Educação. Cia. Editora Nacional, São Paulo.

LE GOFF, J. (1995) “História Nova", Martins Fontes, São Paulo. (1990) "História; Memória e Documento/Monumento" in Enciclopédia Einaudi Memória-História, Editora Universidade de Campinas, Campinas LIMA, H.; ARANTES, A. (1984) "História da Ação Popular, da JUC ao PCdoB" 2a . edição, Editora Alfa-Omega, São Paulo

LODI, N, (1977) “Boletim Sapere Aude” no. 20, ano XIII, São José do Rio Preto LUKÁCS, G. (1969) “História e Consciência de Classe”. Editora Grijaldo. México. MAGALDI, S.(1984) “Um palco brasileiro: O Arena de São Paulo." Editora Brasiliense. São Paulo.

MARKUN, P.(1961), " 1961, que as armas não falem", Editora Senac, São Paulo. 
MARX, K. ENGELS, F. (2002) "Manifesto do Partido Comunista", Editora Martin Claret. Rio de Janeiro.

MECHI,P.S. (2006) "A educação no Brasil" in:Revista Espaço Acadêmico no.66, São Paulo.

MEIHY, J. C. S. (1996/2005)“Manual de História Oral” 5a. edição, Edições Loyola, São Paulo.

MEIHY, J.C.S.; HOLLANDA, F. (2007) "História Oral Como Fazer Como Pensar", Editora Contexto, São Paulo.

MEIHY, J.C.S. (1990) “A Colônia Brasilianista”. Nova Stella Editorial. São Paulo.

MENDONÇA,S.R. (1994) “Dez anos de economia brasileira: História e historiografia (19541964)" in Revista Brasileira de História, no. 27 -p. 87. Editora Marco Zero. São Paulo

NAPOLITANO, M. (2002) “Cultura e poder no Brasil Contemporâneo", Juruá Editora, Curitiba.

MICELI, S. Folha de São Paulo, 8 de julho de 2000. Especial, no. 64, p.1.

OLIVEIRA, N.R. de. (1989) "Sapere Audi".Dissertação de Mestrado, São Carlos.UFSCAR.

OLIVEIRA,E.(1976) “As Forças Armadas: Política e Ideologia no Brasil”.Editora Vozes, São Paulo.

ORLANDI, E. P. (1997). "As formas do silêncio: No movimento dos sentidos", Campinas, São Paulo, Editora UNICAMP

ORTIZ, R. (1985),"Cultura Brasileira e Identidade Nacional", Editora Brasiliense, São Paulo.

PAES,M.H.S. (1997)," A década de 60. Rebeldia, contestação e repressão política". Editora Ática, São Paulo. 
PECÁUT, D. (1990) “Os Intelectuais e a Política no Brasil”, Editora Ática, São Paulo.

POLLACK, M.in "Memória, Esquecimento, Silêncio" in Estudos Históricos, Rio de Janeiro, vol.2, n. 3, 1989, p.3-15.

PORTELLI, A.(1997) “Tentando aprender um pouquinho. Algumas reflexões sobre a ética em História Oral" in Projeto História no. 15, PUC , São Paulo

REIS, D.A.(1990) "A Revolução faltou ao Encontro", 2a . edição, Editora Brasiliense, São Paulo.

REIS, D.A. RIDENTI, M. MOTTA, R.P.S. (2004) “O Golpe e a Ditadura Militar 40 anos depois", Editora Edusc, Bauru.

RIDENTI, M. (1995) “Professores e Ativistas da Esfera Pública", Cortez Editora, São Paulo. (1993) “O Fantasma da Revolução Brasileira”, Editora Unesp, São Paulo.

SCHWARZ, R. (1992) “O Pai de Família e Outros Estudos” Paz e Terra, São Paulo

SILVA,D.A. (1995). “Ensino Superior - Um estudo de memória social”. Dissertação de Mestrado, Unesp, Araraquara.

SZACKI, J. (1972) “As Utopias ou A Felicidade Imaginada” Paz e Terra, Rio de Janeiro.

SODRÉ, Nelson Werneck, (1984) “Vida e Morte da Ditadura”, Vozes, Rio de Janeiro.

SOUZA, P.N.P. (1991) "Estrutura e Funcionamento do Ensino Superior Brasileiro", Pioneira Ciências Sociais, São Paulo.

THOMPSON,P. ((2002) "A Voz do Passado História Oral", Paz e Terra, São Paulo.

TOLEDO, C.N. (1982) “O governo Goulart e o golpe de 64", Editora Brasiliense, São Paulo.

VENTURA, Z. (1988) “1968 o ano que não terminou”, Editora Nova Fronteira , Rio de Janeiro. 
ANEXOS 


\begin{abstract}
ANEXO I
As fotografias aqui inseridas não são meramente ilustrativas, porém, não pretendo realizar um estudo iconográfico sobre as mesmas. Minha intenção é que possam estabelecer uma aproximação maior entre os entrevistados e os leitores desse trabalho. Foram cedidas pela Unesp de São José do Rio Preto e também se encontram no site da Instituição.
\end{abstract}




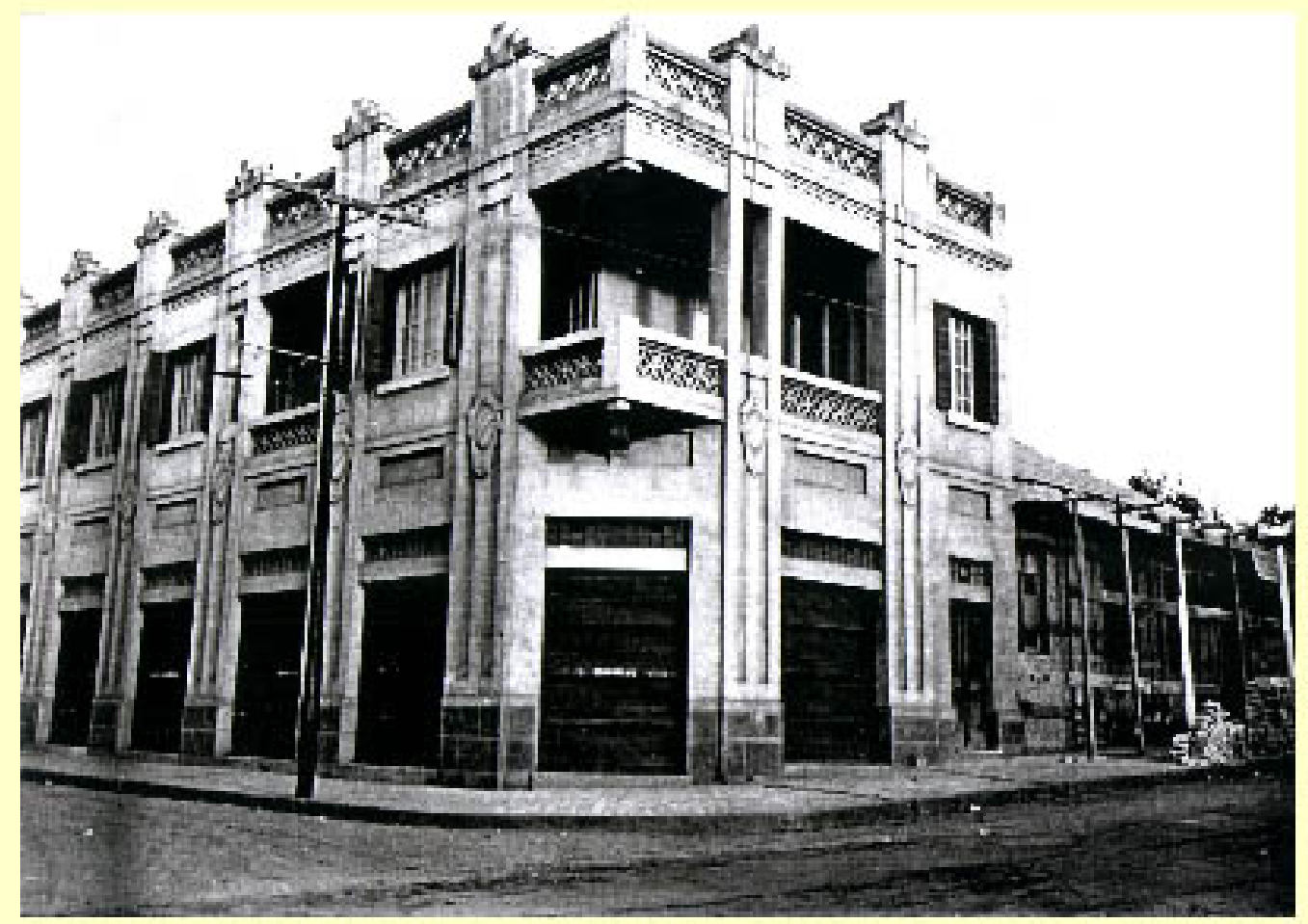

O segundo prédio em que funcionou a FAFI de Sẫo José do Rio preto. Antiga residência da família Mussi, alugada em 1958. Nela funcionou, até 1960 , a diretoria, a biblioteca e salas de aulas dos cursos de Letras.

No terraço superior, local para festas de confraternizaçẫo dos alunos. 


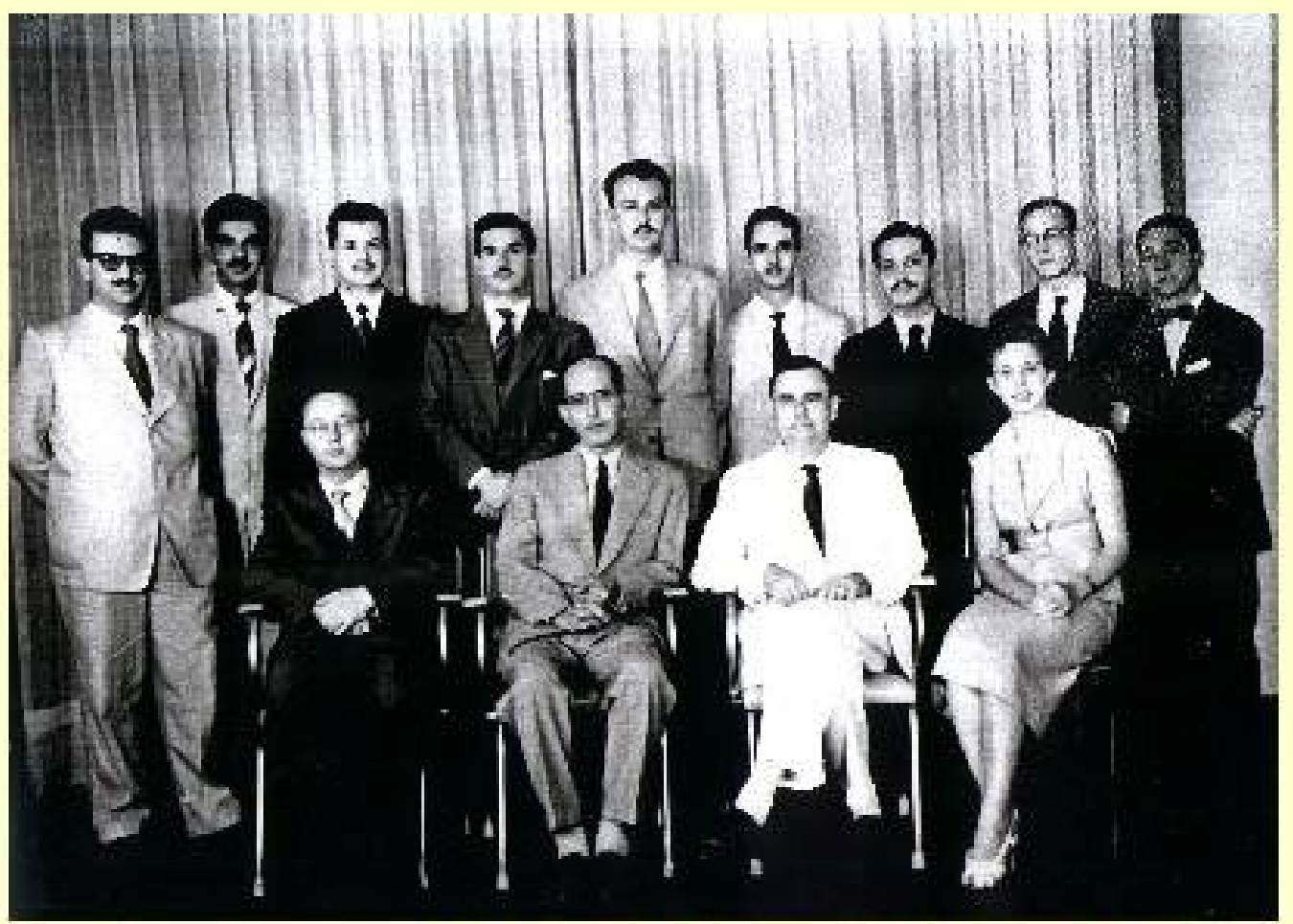

Os primeiros professores da Faculdade de Filosofia de Sẫo José do Rio Preto FAFI - 1957.

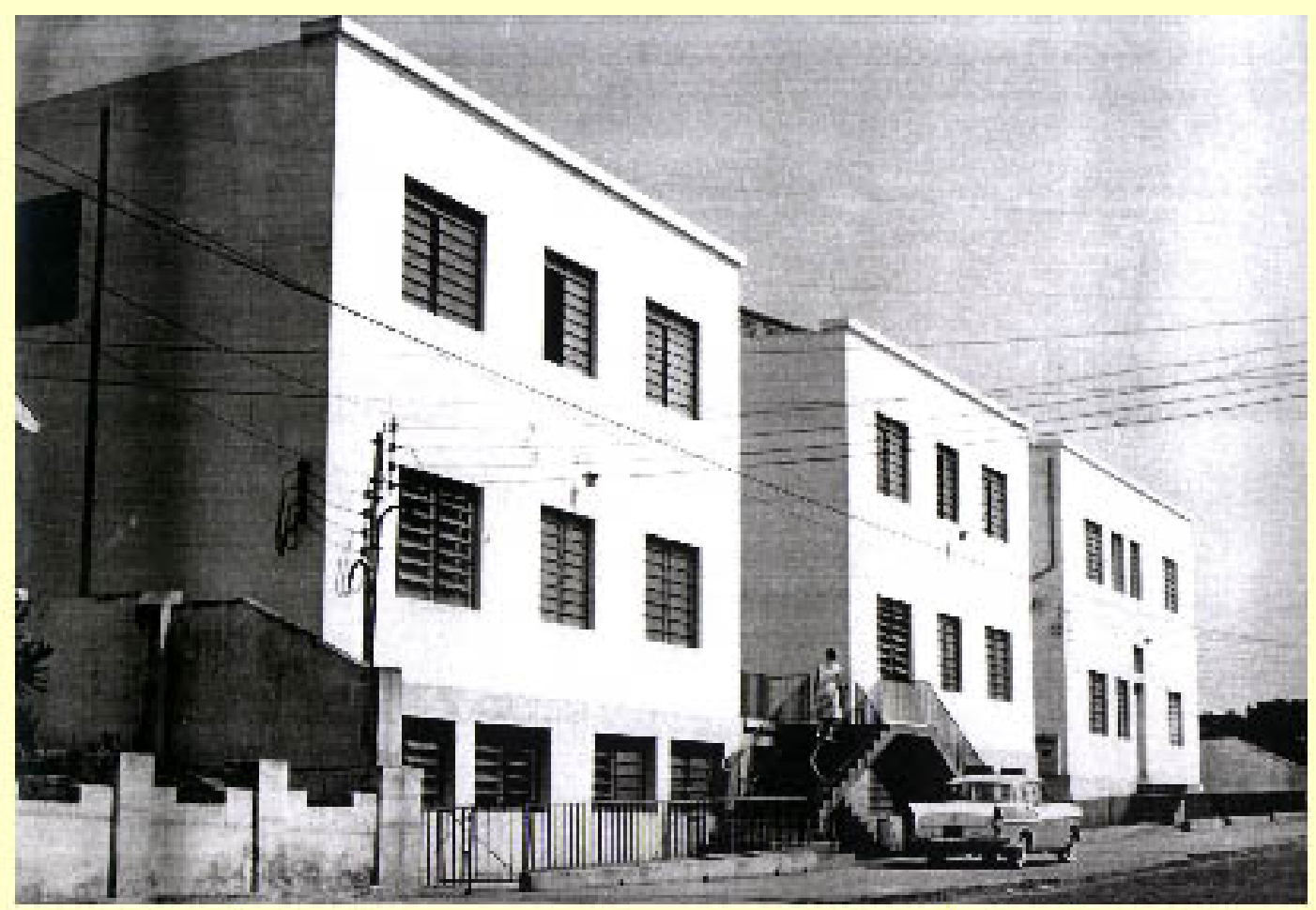

O terceiro prédio em que funcionou a FAFI de Sẫo José do Rio Preto. Antigo hospital adquirido pela Prefeitura Municipal, foi colocado à disposiçẫo da escola a partir do segundo semestre de 1960. Local: Rua General Glicério Vila Redentora. 


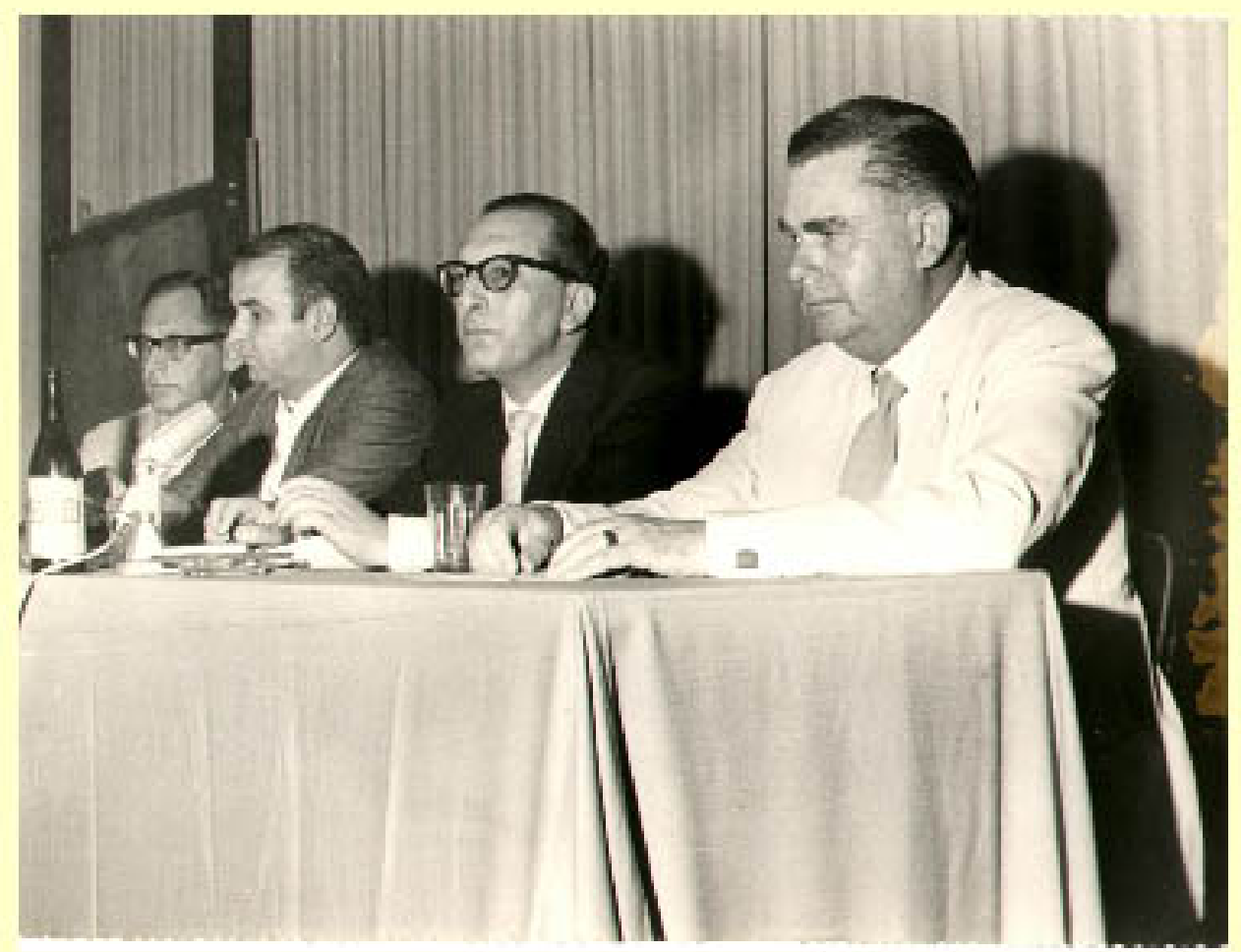

Instituto de Biociências, Letras e Ciências ExatasiUNE SP _Campus de Sẫo José do Rio Preto Prof. Dr. Orestes Nigro - FAFI, Govemador Dr. Carlos Lacerda e Prof. Dr. Amold Von Buggenhagen-FAFI - anos 60 .

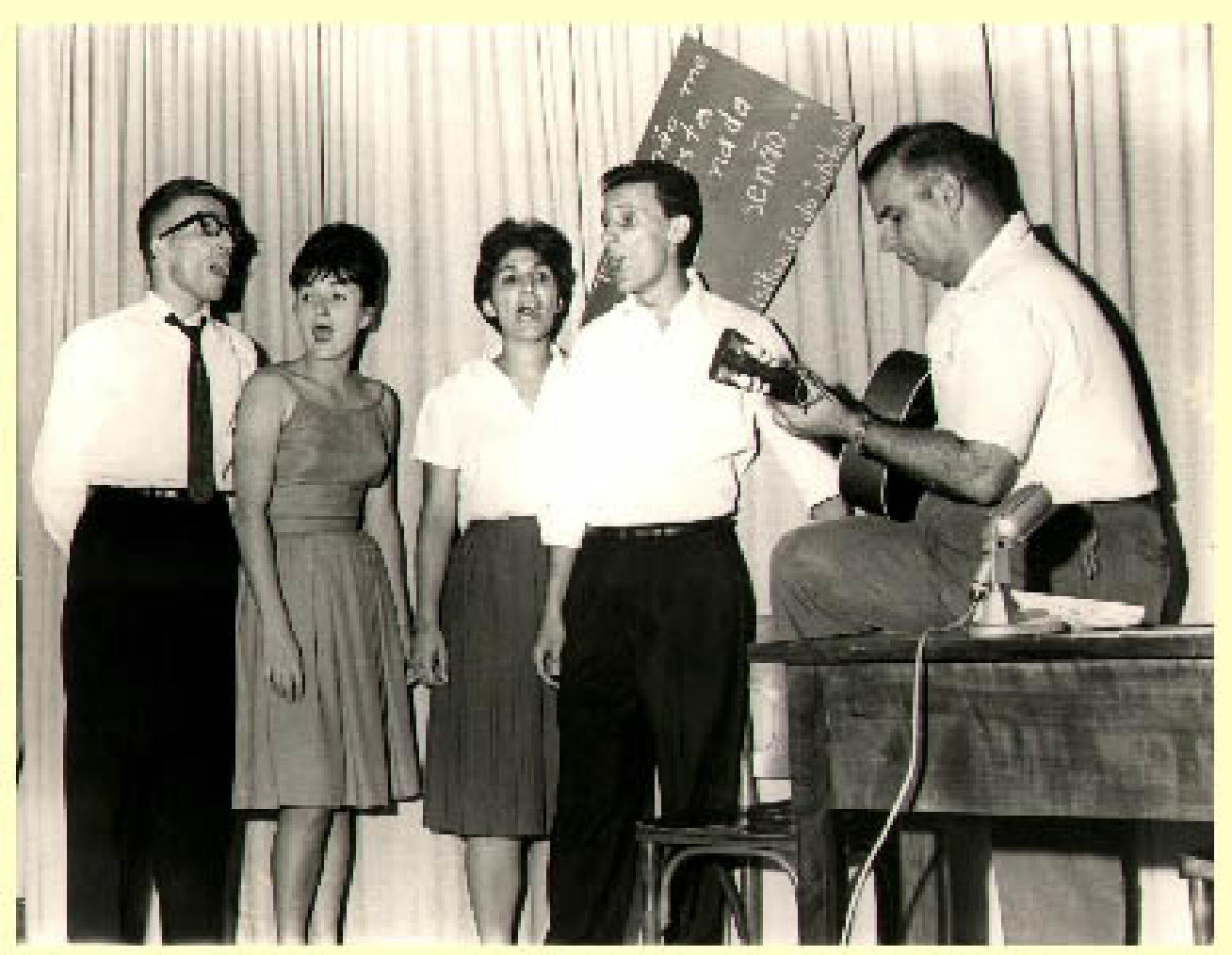

Instituto de Biociências, Letras e Ciências ExatasiUNE SP -Campus de Sẫo José do Rio Preto GRUTA - Grupo de Teatro Amador da FAFI - Prof. Dr. Orestes Nigro e Grupo de Alunos na Recepçẫo de Calouros-1962. 


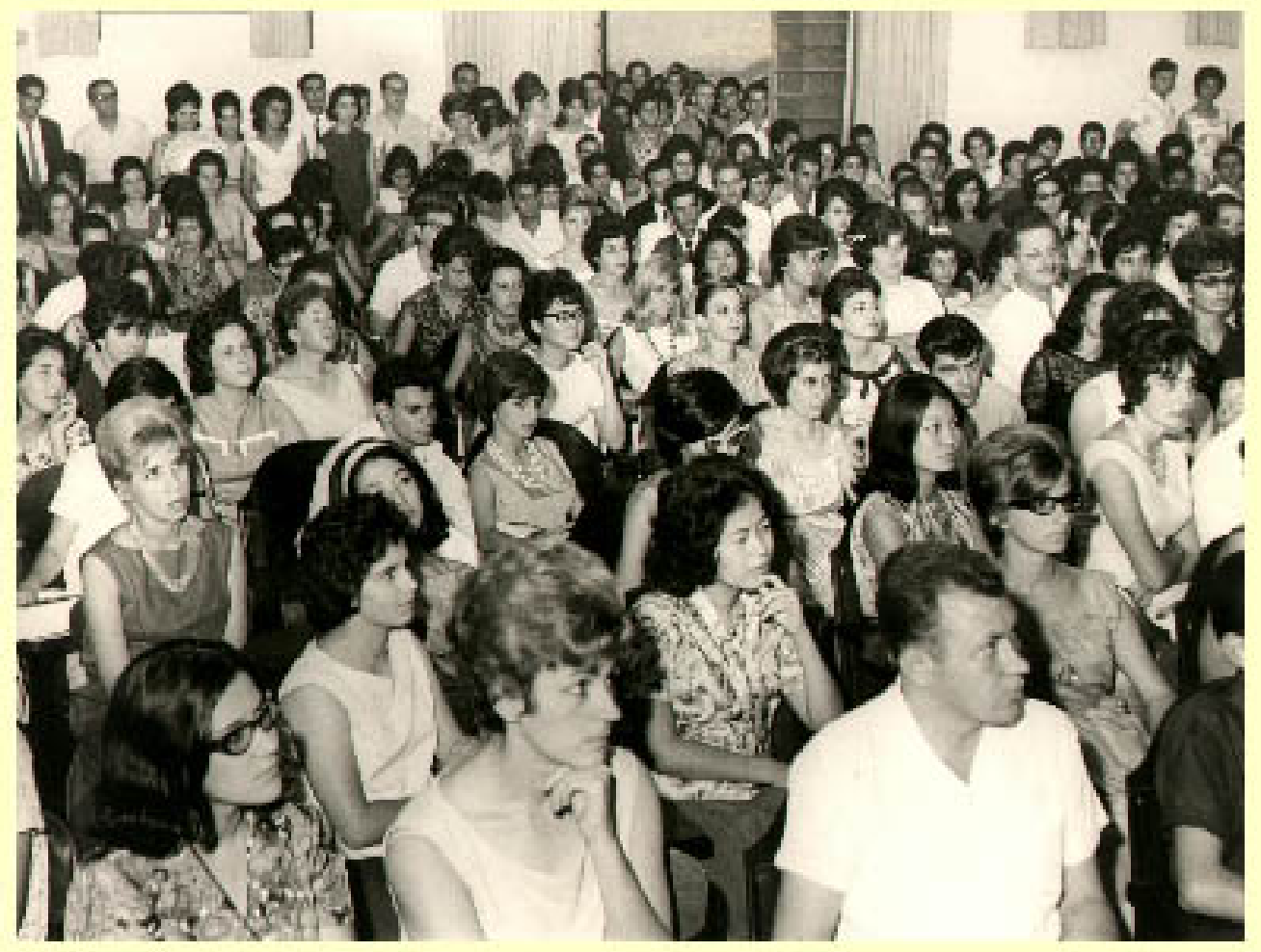

Instituto de Biociências, Letras e Ciências ExatasiUNE SP _Campus de Sẫo José do Rio Preto GRUTA - Platéia de alunos e funcionários - FAFI - evento cultural - anos 60.

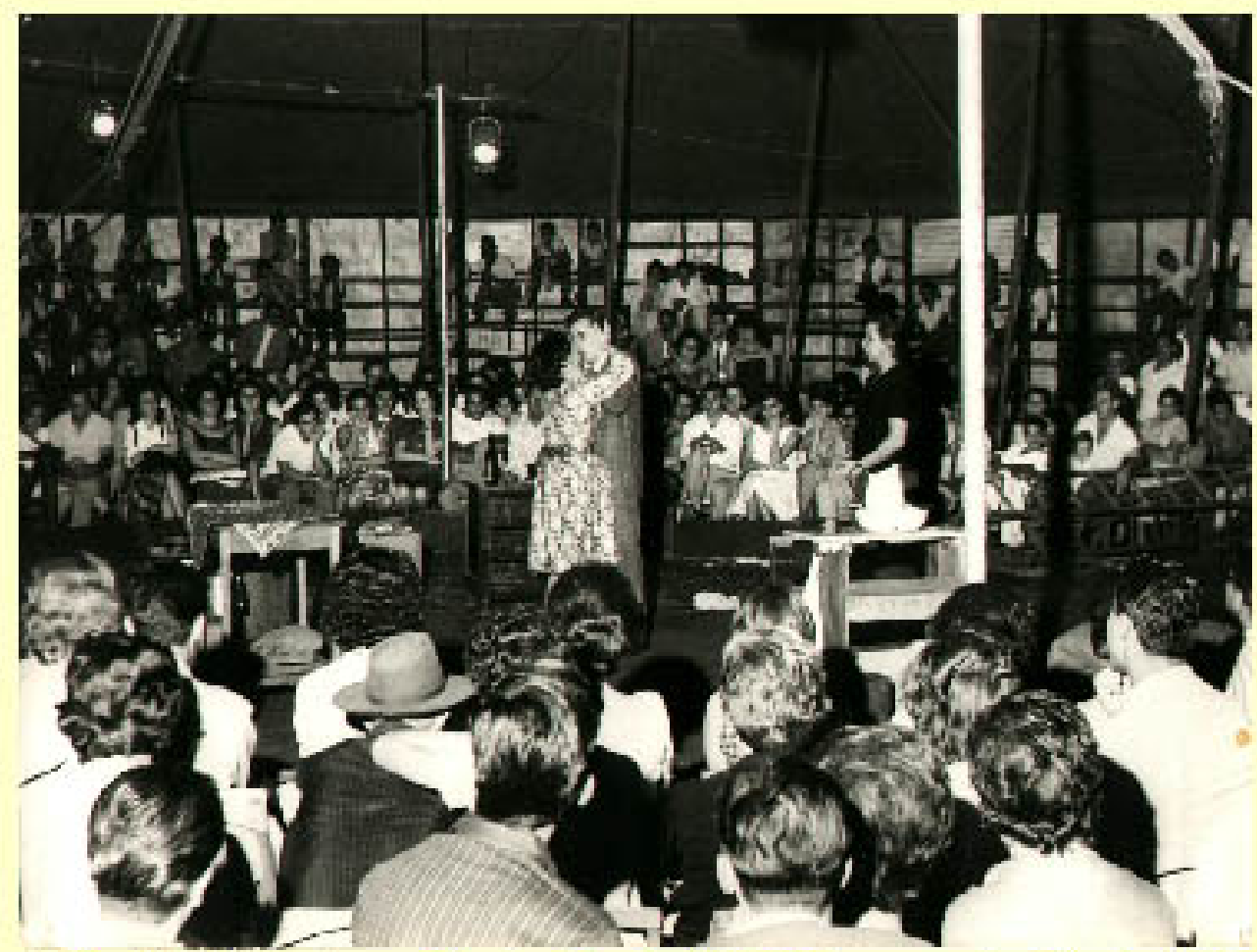

Institu to de Biociências, Letras e Ciências ExatasiUNE SP Campus de Sẫo José do Rio Preto GRUTA -Grupo de Teatro Amador da FAFI - Peça "Eles nã̃o usam Black-Tie" Teatro de Arena em Sấo José do Rio Preto - em cena o ator Guarnieri - 07 de setembro de 1962 - 


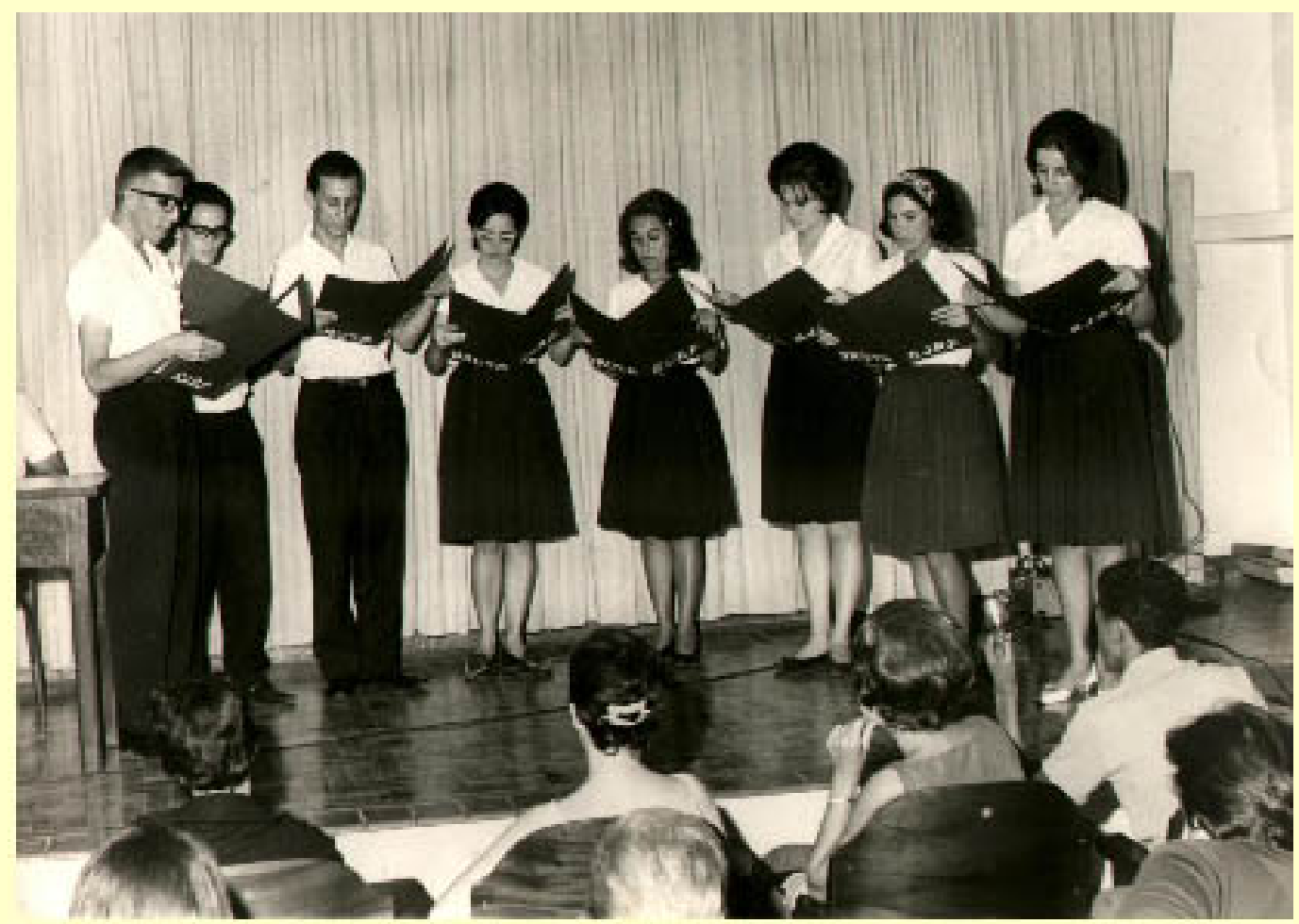

Instituto de Biociências, Letras e Ciências ExatasiUnNE SP _Campus de Sẫo José do Rio Preto GRUTA - Grupo de Teatro Amador da FAFI - Dia do Calouro - abril de 1963.

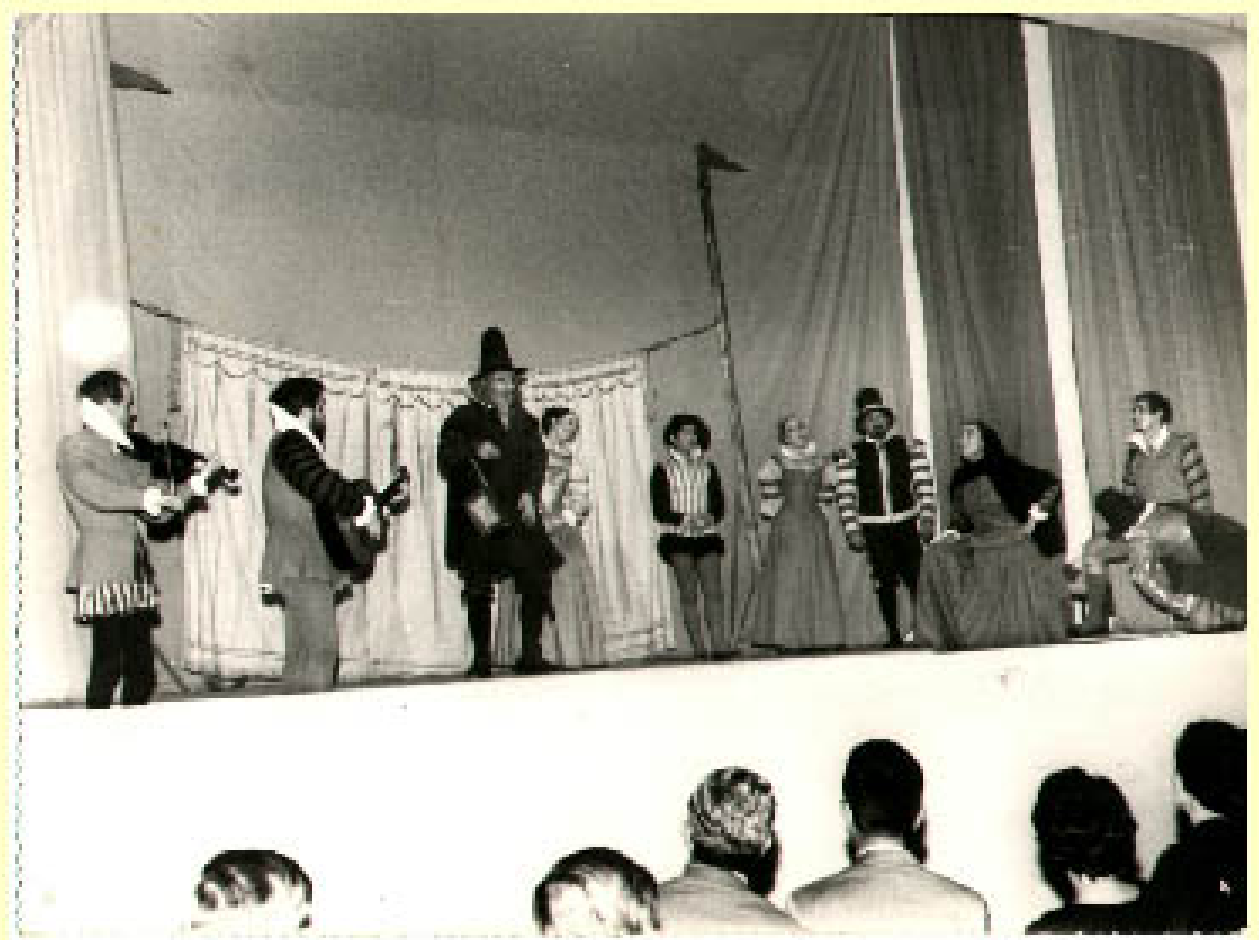

Instituto de Biociências, Letras e Ciências Exatasi'UNE SP -Campus de Sẫo José do Rio Preto GRUTA - Representação de "O velho ciumento", de Cervantes, pelo Teatro dos 7 . no palco da sede nova do Rio Preto Automóvel Club, durante a Semana de Estudos Brasileiros - 1962. 


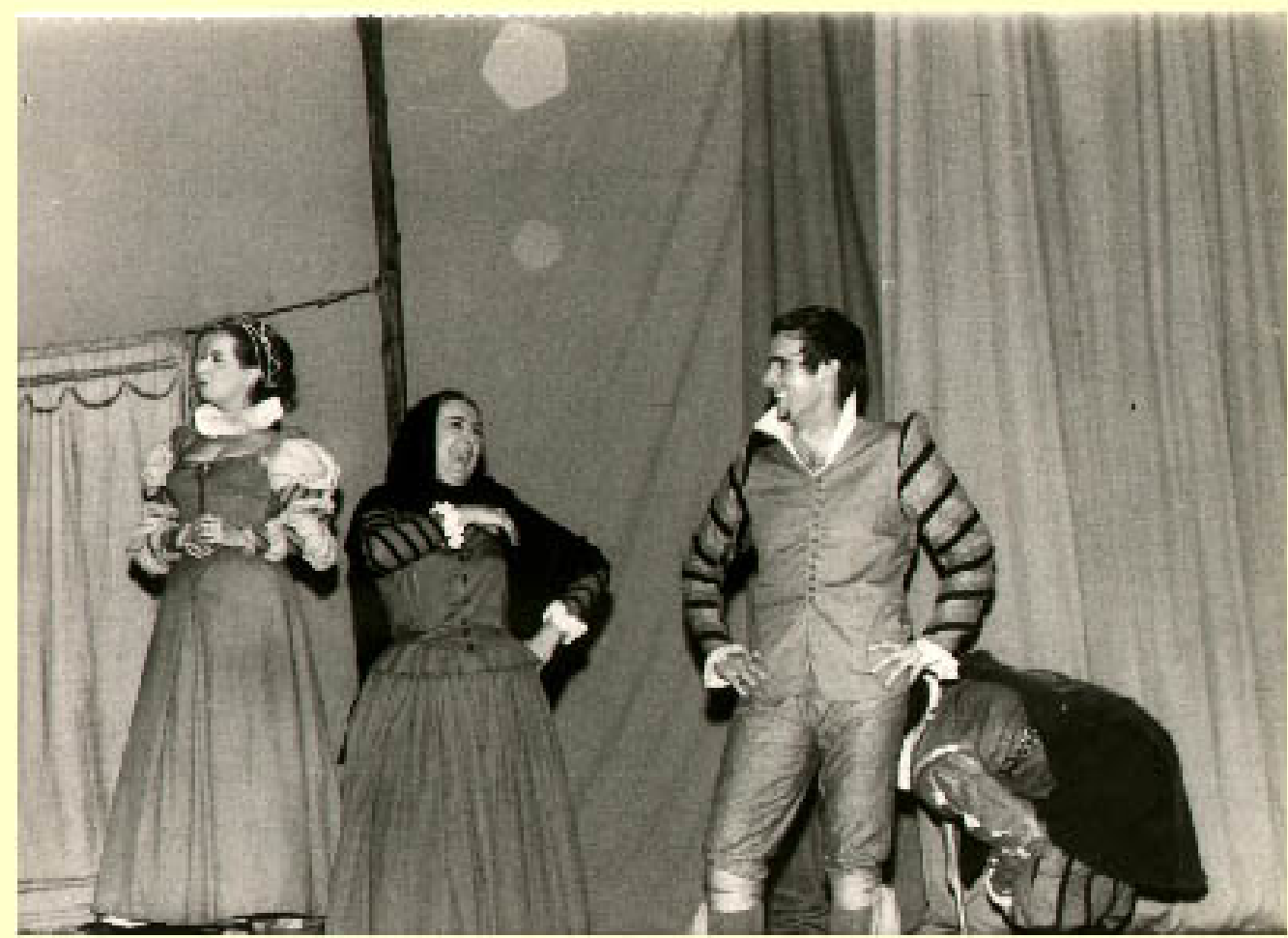

Instituto de Biociências, Letras e Ciências ExatasiUnNE SP _Campus de Sẫo José do Rio Preto GRUTA - peça "O velho ciumento" - em cena o ator Francisco Cuoco - anos 1962. 


\section{ANEXO 2}

Os artigos a seguir foram publicados pela imprensa riopretense por ocasião da fundação da Faculdade. 
Serão realizados os exames vestibülares da Faculdade de Filo- sofia de Rio Preto

NESTA SEMANA O PRESIDENTE DA REPU BLICA DEVERA' ASSINAR O DECRETO CURSOS - PROVIDENCIAS COMPLEMENTA RES DA PREFEITURA IVUNICIPAL - OFI. CIO DE AGRADECIMENTO DA COMISSÃO DE ESTUDANTES

Depois de autorizado realizar os exames vesti- foi de todos. Todos bata- ferto com a cessão diária pelo Conselho Nacional bulares na segunda quin- lharam e se esforcaram, de grande espaco no jorde Educaçáo, o funciona- zena de março vindouro. mento ainda este ano da Para essas medidos já Faculdade de Filosofia, existe a verba necessária. Ciencias e Latras de Rio Preto, a Prefeitura Muni cipal aguarda apenas a assinatura do decreto pelo Dr. Juscelino Kubitschek, o que deverá darse nesta semana, para tomar várias providencias, entre as quals podemos adiantar:

1) Ligeira reforma do prédio do Instituto de $\mathbf{E}$ ducação Monsenhor Gancalves, adaptando melhor algumas salas;

2) solicitar ao Gover 2) Solicitar ao ,Gover-
nador do Estado, Dr. Jânio Quadros, a nomeaçào de mais sete professores, porquanto apenas cinco possuem cadelras; e CURSOS

A Faculdade manterá os"seguintes cursos:

Historia Natural; . LEtras Neo-Latinas; Letiras dagogia.

OFICIO DE AGRALECIMENTO

A comissĩa de Estu dantes 'em $\mathrm{prl}_{\mathrm{da}} \mathrm{Fa}$ culdade de Filosofia, canstituida dos joxens David Rahd, Ebrahim Ra madan Décio Sicueira Sebastião Dagoberto, Antonio Imis eimentel $A y r-$ to Anates Ferraz a Ga ber Lopes, enviou à "A NOTICIA" o seguinte 0 fício de agradecimento: "Senhor Diretor: Neste momento alegre para São Jose do Río Preto, quando o puvo festeja a autorização para funcionamento de sua primeira Escola de Ensi= no Superior, nós, que fazemos parte da "Comissão de Estudantes em Pról da F'aculdade de Filosofia", näo poderiamos esquecer-nos desse jornal tão bem dirigido por V.S Inestimavel foi a cooseração oferecida. Desassombrado vibrante, conseguiu esse jcrnal, senhor Diretor, uma cousa que parecia impossivel: A união de todos os riopretenses. Pela primeira vez, nesta cidade, assistimos'o - espetáculo maravilhoso da união dos políticos e do povo, das entidacies de classe e firmas particulares. Estudantes irmanados com operários, todos tendo em vista somente um objetivo, um grande e nobre objetivo: o funcionamento de nossa F'aculdade de filosofia.

E é por isso, senhor Diretor, que queremos am gradecer-lhe. A vitoria estimulados pelo apoio vi nal, para nossas notícias, brante desse jornal. A- feito tudo gratuttamente. gradecer-lhe a acolhida Em nome desta querida dada a tudo que se rela- e maravilhosa São José : cionasse com nossa Fa- do Rio Preto, nós mais u. culdade. Agradecer-lhe ma vez, dizemos: MUITO pelo : sacrificio financeirol OBRIGADOS".

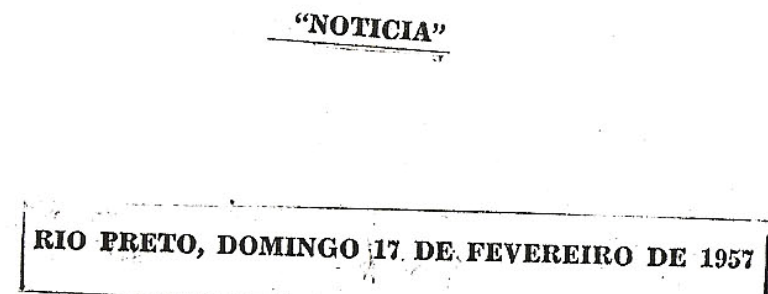




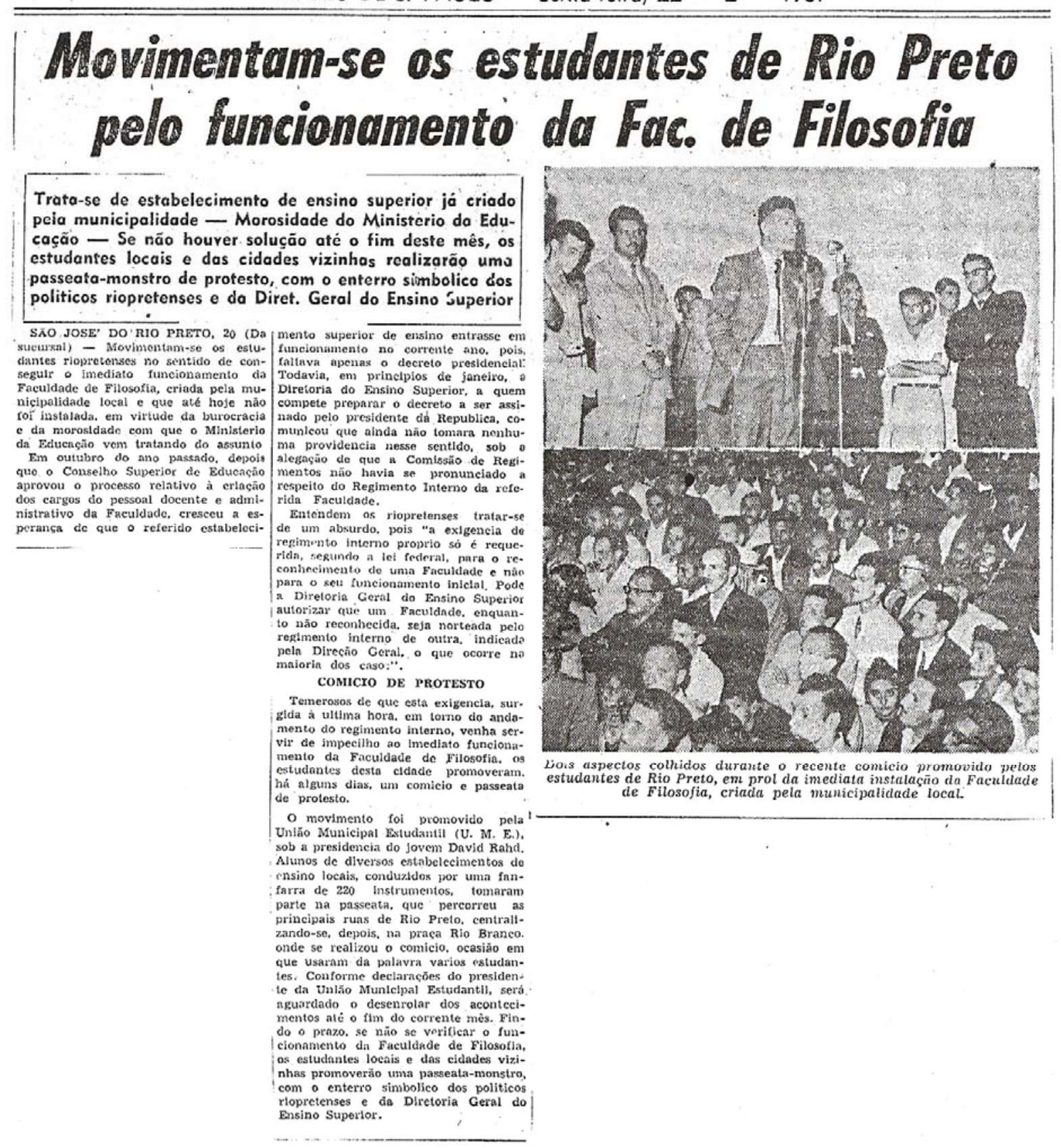




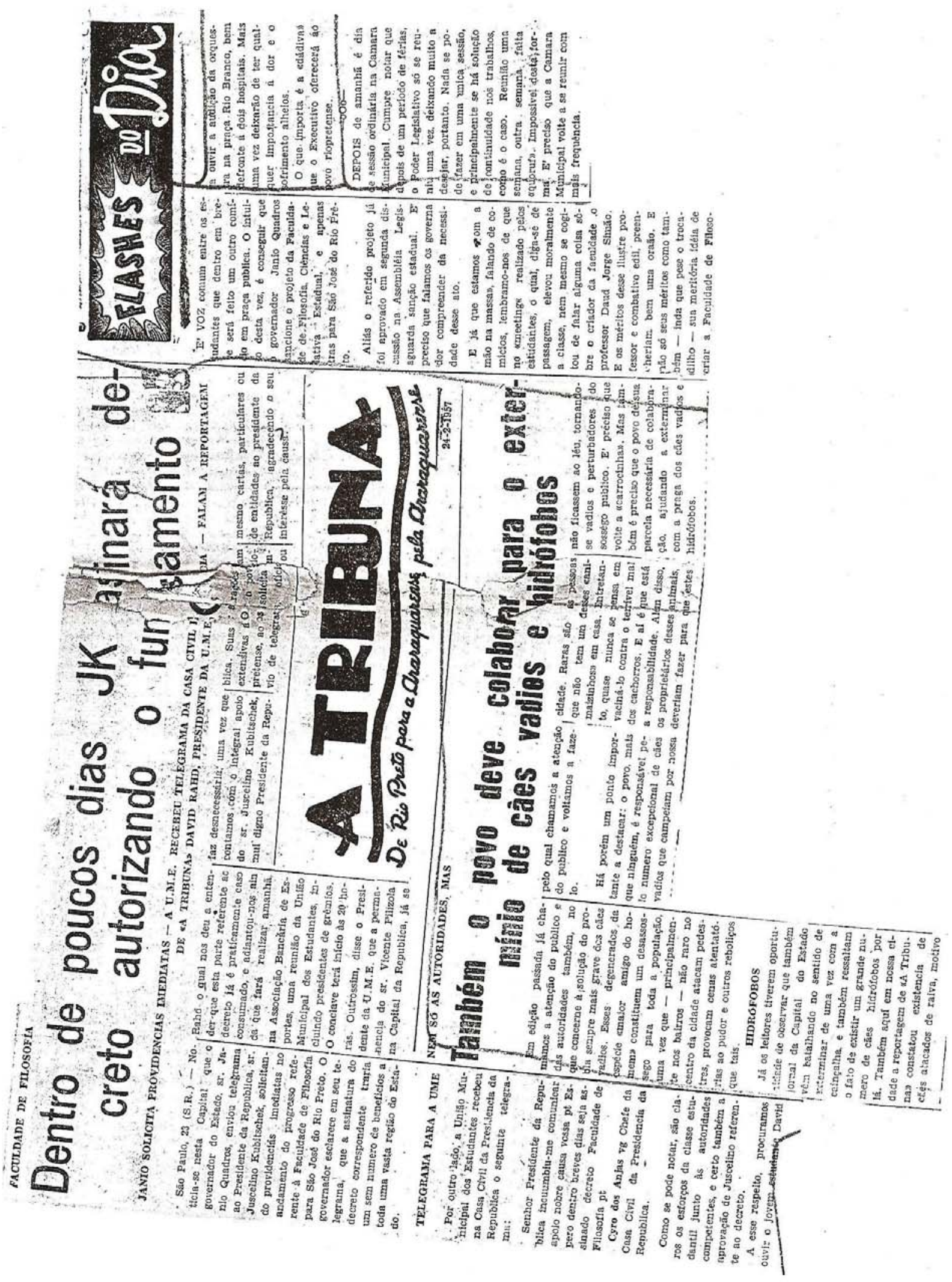




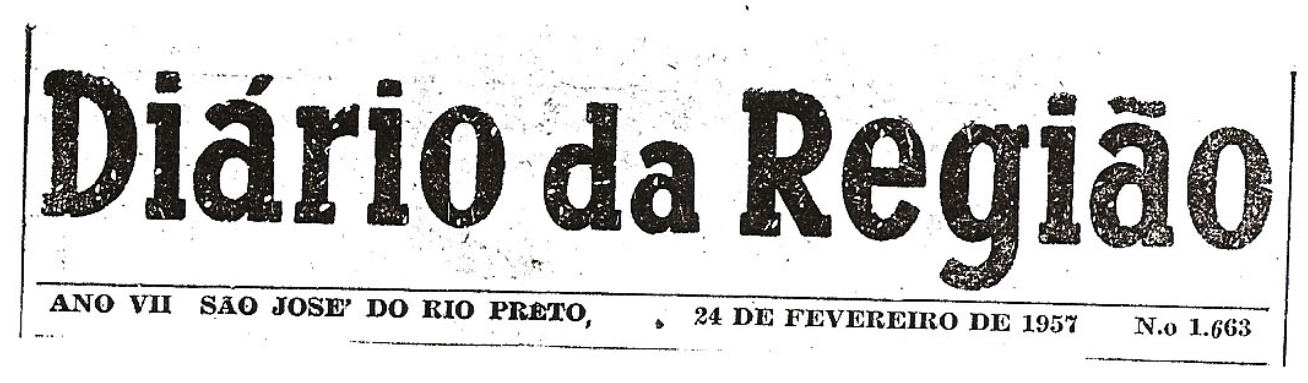

Funcionamento da Faculdade de Filosofia

\section{Solicita Jânio Quiadiros a atenção do presidente Juscelino Kubitschek}

\section{Enviado telegrama pedindo seja assinado rapidamente o decreto presi- dencial - Telegrama da presidência da República aos estudantes rio- pretenses - Reunião amanhã da UME}

O governador Janio Qua- |j sa iniciativa pioneira, voltou a jos - Chefe da Casa Civil da dros, que tanto vem se interessando pelo funcionamento de nossa Faculdade de Filosofia, Ciências e Letras, desde que tomou conhecimento desmanifestar-se em favor do Presidência da República». mento dêsse curso superior em nossa terra.

ôntem o governador enviou um telegrama ao presidente da República, sr. Juscelino Kubitschek, solicitando ao mesmo que venha a assinar o mais rápido possível o decreto para a funcionamento da Faculdade de Filosofia de São José do Rio Prêto, pois o caso é de importância para o Esstado de São Paulo, envolvendo os'interesses de uma vasta região paulista.

\section{TZLEGRAMA AOS ESTUDANTLS}

A respeito ainda do funcionamento da nossa Faculdado de Filosofia, Ciências e Letras, - chefe dá Casa Civil da pre. sidência da República envioı REUNIão AMANHã DA UME

O sr. David Rahad, presidente da Comisșão dos Estudantes Riopretenses que desen. volveu a campanha pró íun. conamento da Faculdáde de Filosofia, e nomeado presidente da União Municipal dos Estudantes, comunicou-nos que será realizada amanhã, segunda-fe.ra, uma reunião da União Municipal dos Eitudantes.

Issa reunião será realizada na séde da Associação Bancária de Esportes, às 20 horas, estão sendo convidados para a mesma todos os estu. dantes riopretenjes, assim cotelegrama à União Municipal dos Estudantes riopretenses. isse importante telegrama o seguinte:

«O Senhor Presidente da República incumbiu-me comunicar apôio nobre causa. vossa pt Espera dentro breves dias assinar decreto Faculdade Filosofia pt Cyro dos An- 


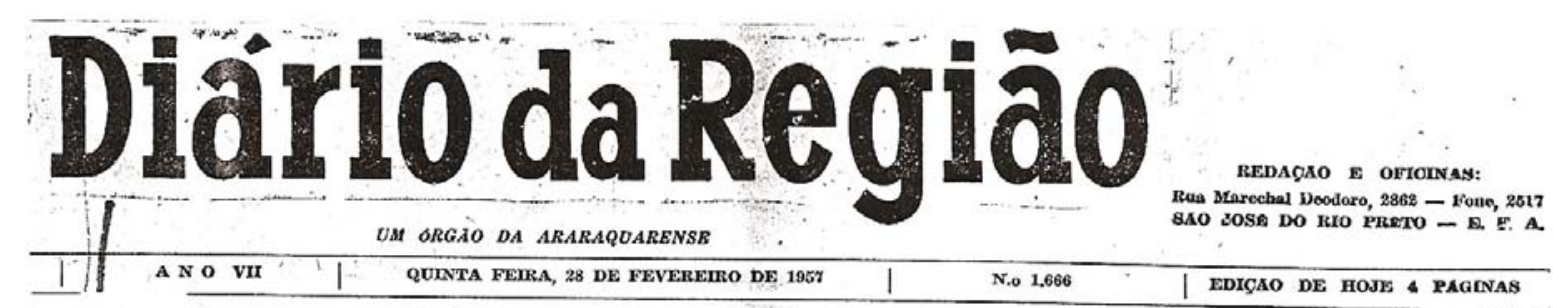

\section{Sancionada ôntem a leí para o funcio- namento da Faculdade de Fílosofia}

0 presidente da República assinou o decreto n.o 41.061, de 27-2-57, que deverá ser publicado pelo «Diário Oficial» da União de hoje - Resta a aprovação do Calendário, cuja au torização será dada pelo Diretor do Departamento Nacional de Educação -- Ainda na capital Federal, o sr. Vicente Filizola sómente regressará quando conseguir mais essa providência

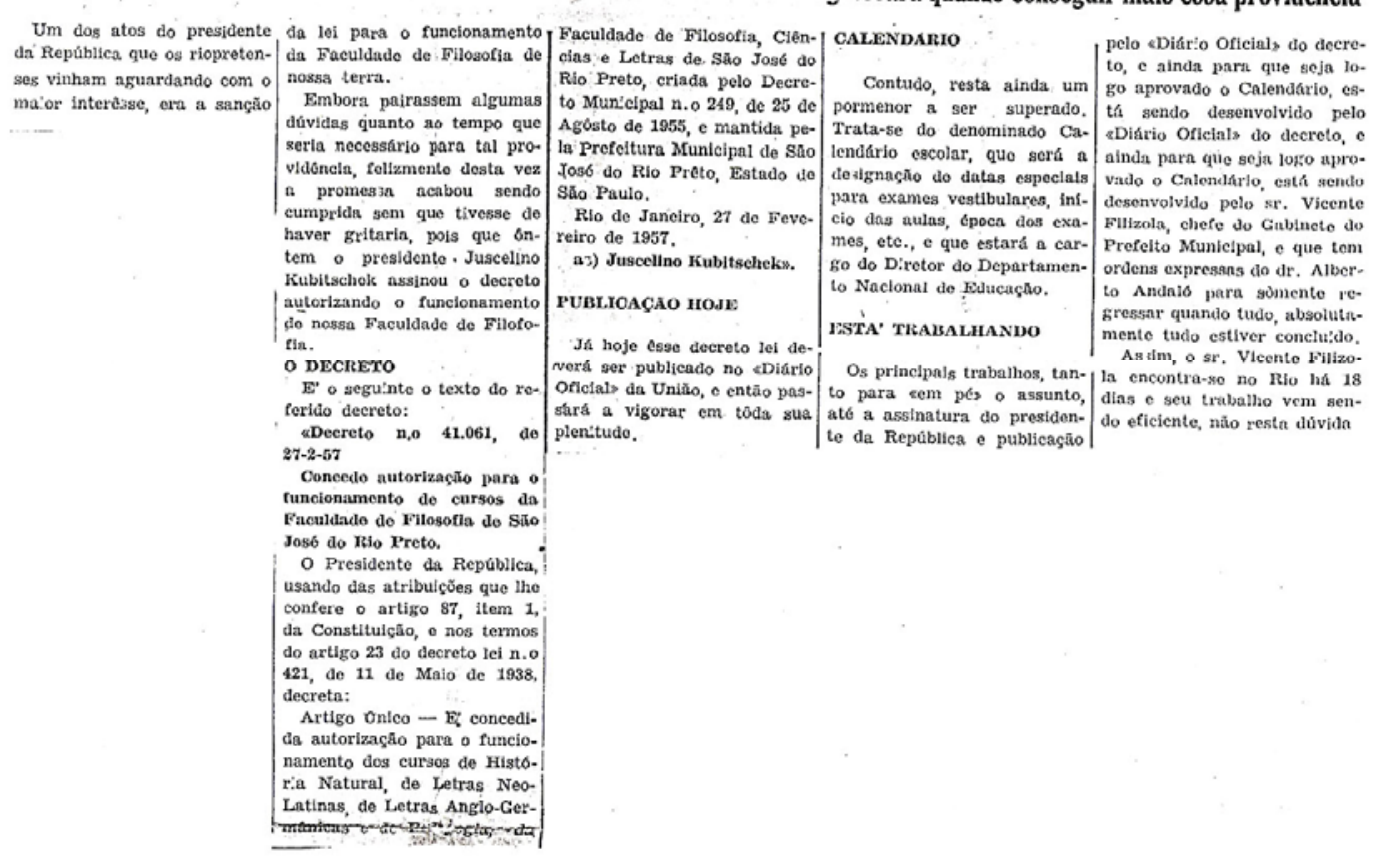


RIO PRETO, $10-4-1957$

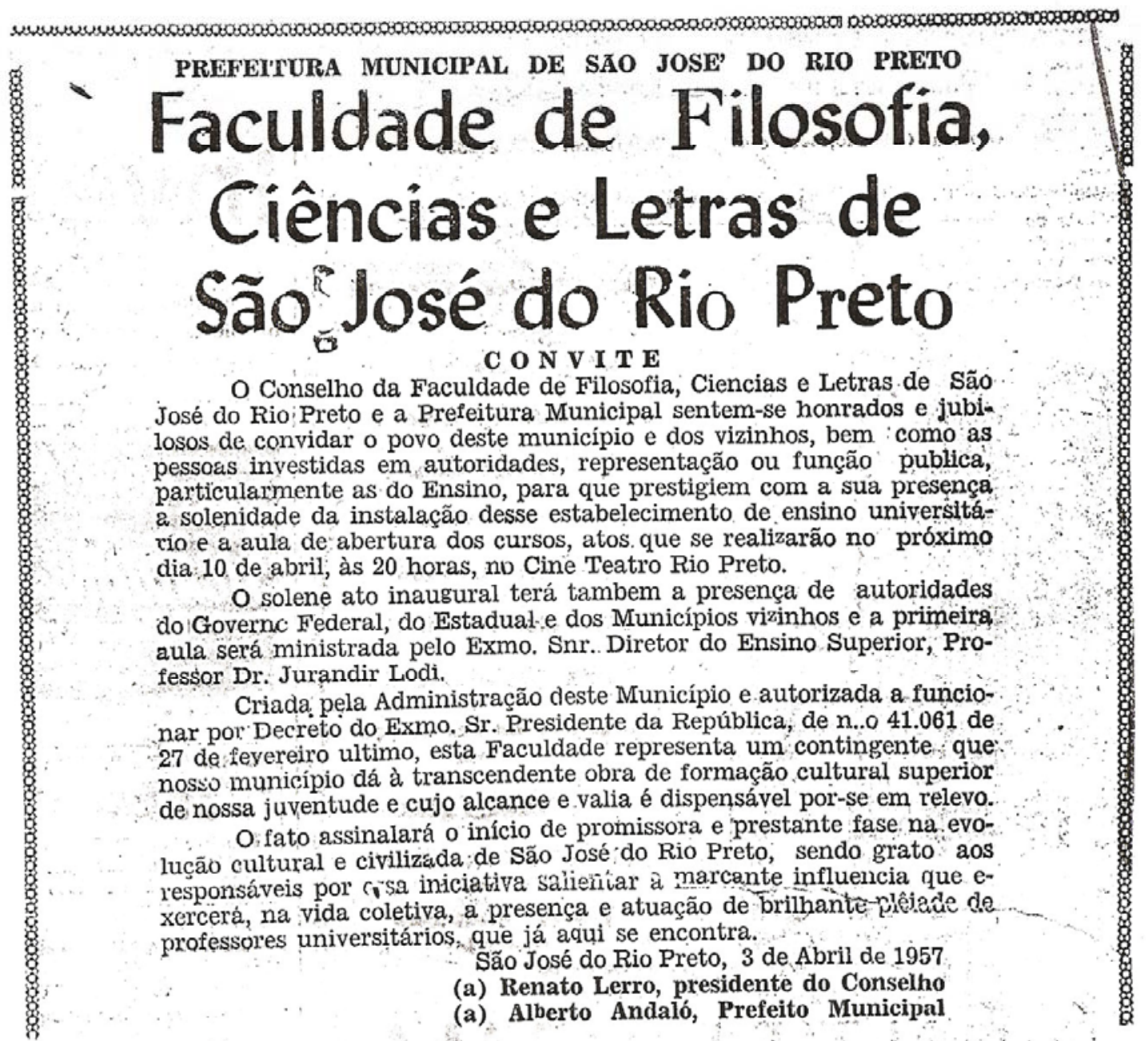

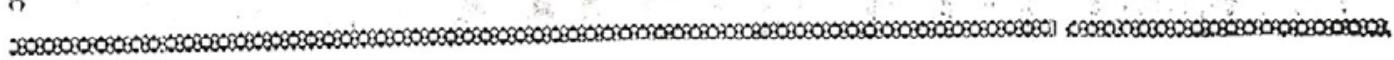




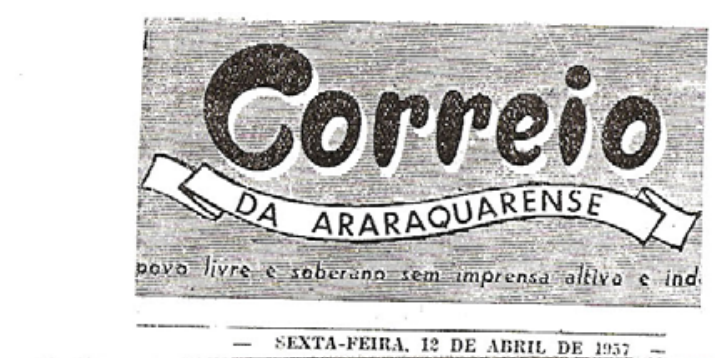

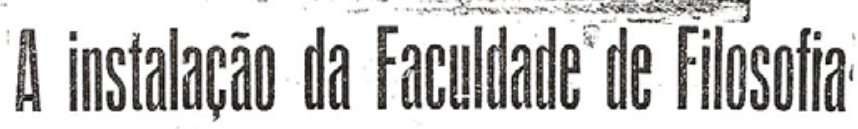
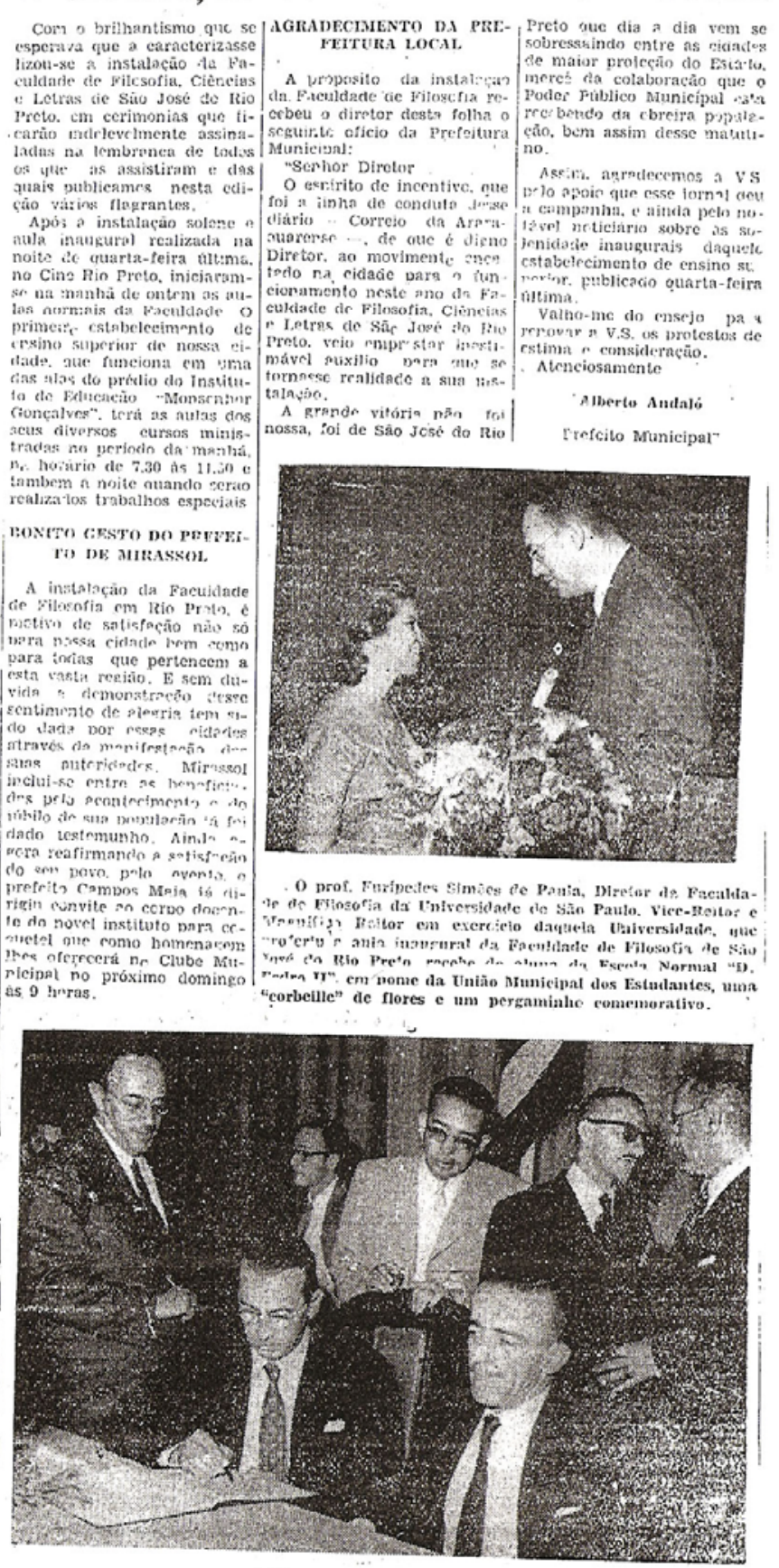

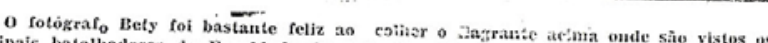

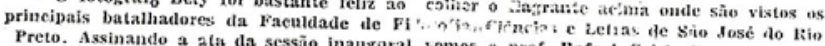
estabetecimento. (endo a seu tado o dr. Alber tre inos o prof. Rafaci (Grisi, diretor daquete

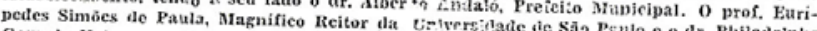
Ge'trcia Neto, aguardam a oportunitarle para porem naque'c lirro as suas philatelpho

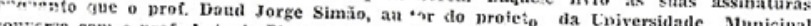

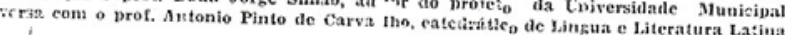




\section{ANEXO 3}

Os artigos a seguir foram publicados nos jornais riopretenses. Trata-se da altercação ocorrida entre professores da USP e da cidade sobre a Fafi. A partir do momento em que essas discussões tornaram-se públicas a ruptura aconteceu de maneira irreversível. 
S. G. $-11-63$ - S.A.C. - S.S.P. - Mod. $27-$ Int. -200.000

SECRETARIA DA SEGURANÇA PÓBLICA

DELEGACIA

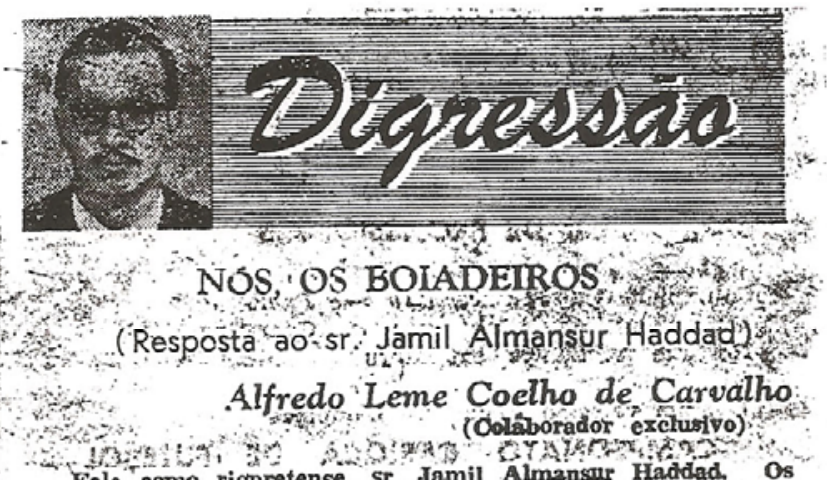

Falo como riopretense sr. Jamil Almansur Haddad os

fatos năo são tão simples como o sr. escineveu 0 sr. deviạ saber que nessa Faculdade de que fala; e aly conhecer bem, há muitos professories comumistas.

Tados nós sabemos que há pessóas sem cultura que vêom comunismo até onde êle nưo existe. Mas o sr.'näo negará qué há também ingênuos que ñân percebèm o comunismo ande êlo na verdade está o que parece muito clara aos que em Rio Preto têm contato com os mejos universitarios, o năto so dejxam iludir por cortinas de Tumaga, "que um grande nút mero de professôres deśssa Faculdad tên no minimo stinapatia pelo movimento commista é no insimo muito mais

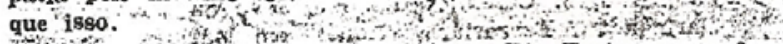
o sr. diz textualmente, que uem Bio-Preto um professor que ouse dizer que morre muita criangs no Nardeste que $50 \%$ da populaçân é analfabeta pra, cachorro, corre -o zisca de ser ouyido na sua pregaga ensurrecional», por uma aluna virtuosa e mal-amada que togo alertará, a propósito dỏs sinistros designios do -mestro o par bolidoiron, Ls s p w

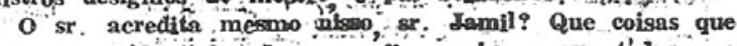
qualquer estudantinho de geografia sabe, e. que todos os candidatos falam nos comicios, às vêzes até com melhor lijnguagem, possam alarmar tanto, como opregacto insurrecio nalu? Śrá que o sr...pensá que no casq de Rio Preto, ná só $50 \%$ mas toda a populaçó o ranalfabeta pra cachorrow?

12. Essa historia de que a tiha do botadeiro, equivoieadamente val contar ao paî que os profésores säo comunistès, e

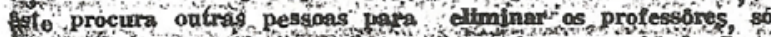
Bude enganar os tolos ou os que na colinecem a cidade. Issó, alís é uma maneira de dizer qué a cidade ênorante. Náno o tiro ignorante assim, sr. Jamil. Hic multa gento aqui que o - ir não comhece. Mesmo porque permanecia multo poucb ep. S. José do Rio Preto quando aqui, lecionotên Isto de finglir que certos professôres esquerdistas sajo perseguidos, quandó na verdade săo èles que dié hoje têm dado: as cartas, só podet lavorecer, apresentando ós como vitining :aos que, em tantos anos, nada têm profluzido de concręto, positivo, dentra dó campo especifico em que deviam trabalhars:s o Estado, com o dinhebro do povo - de um povio que nâdít comunista - paga aos professôres universitírios para que pesquisem; lecionem escrevan dentro da sua matéria. INÉ para que façam propaganda ideológles, para que dediquem seu tempo ao proselitismo político, preparando o adventa da tirania vermelhs at a

E inútil supor que rnós - provincianos no entender de alguns presumidos, só porque nascemos aqui ou aqui vivemos

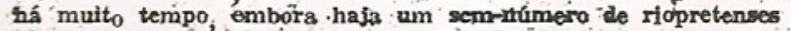
com tim campo muito vasto de experitacia social - acreditemós em anedotas, Nồs sabemos que ó comunismo nessa Fà: culdade, sr. Jamil, náo uma anedota, é um lato. in

Muits gente, pofém que le o seu artigo fors de Rto Proto, poderá pensar qué a nossa cidade é terra de botocudos,

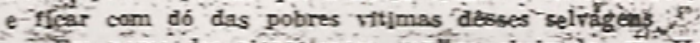

Im nocie dos riopretenses, multe abrigado, $\mathrm{m}$, Haddad,

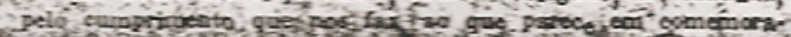
.

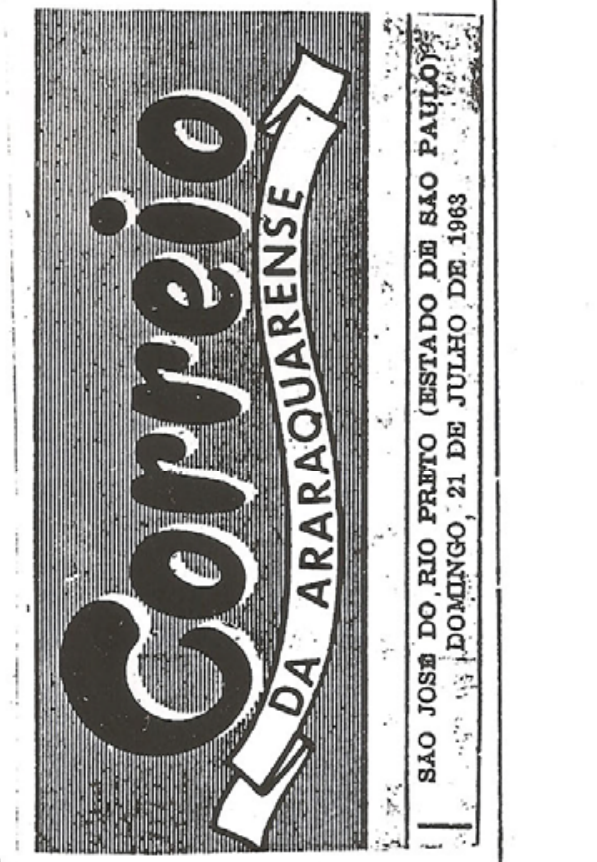




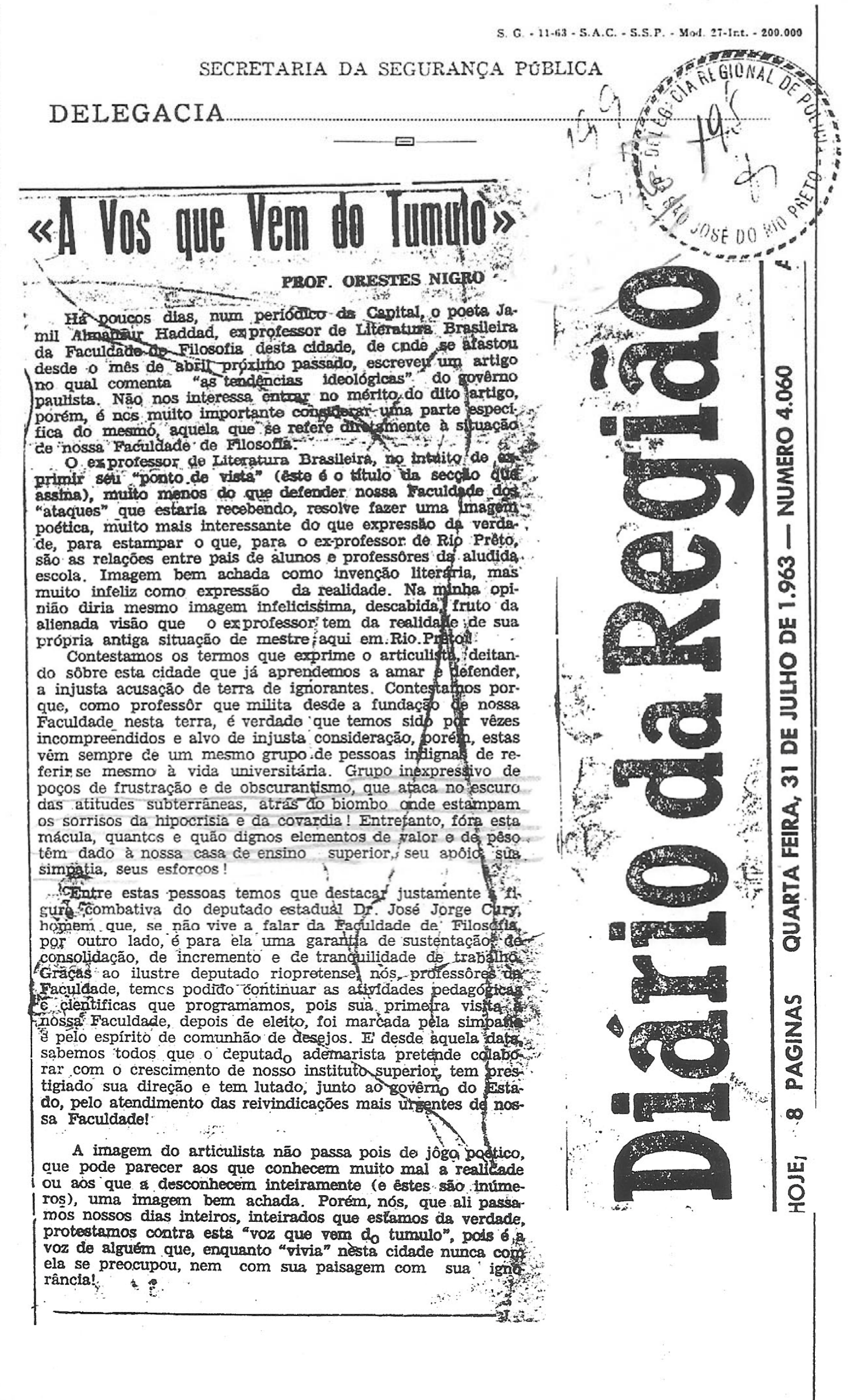




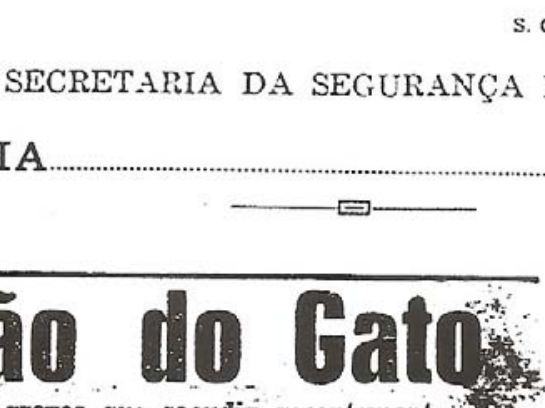

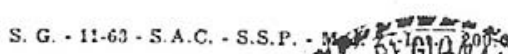

PÉBLICA

DELEGACIA

4 Mão do Gatô.

Ao conjunto de greves que sacudiu recentemente of tado, somouse a dos universitários do Interior. 0 inov mento nasceu em Araraquara e alastrou-se por outras clit. des, paralizando pratticamente os Institutos Isolados, inclusive a Faculdade de Filosofia de nossa terra. Muito mal, quando ise lembra quie o desenvolvimento do ano letivốsé irreversivel o que as aulas perdidas dificlimente poderão ser recuperadas no natural tumulto de encerramento do ano escolar de 1963, que ja se aviafinh,

Näo Possem os motivos que a determinaram et tairez esta greve tivesse passado desapercebids. Estes mottvos, entretanto, provocam a estupefaça de quem delles tomou conhecimento, principalmente por representarem algo de surpreendentemente nôvo em mstéris de movimento reivindicatório. Podese afirmar que'pela primeira vez uma classe - a dos professôres - se acomodou dentro de uma conjuntura administrativa e deixou que outra classe - . a dos seus alumos - defendesse ôs seus interêsses e direitos - lutasse por sua preirrogativg. Esta é de se tirar o chapéu! Se nẫ,' vejamos com os jornais noticiaram os motivos que levaram os universitźrios do Interior a greve: ' equiparaçäo dos salários' dos professôres aos. da Universia ade de São Paulo; acêrto dos contratos dos mesmos proPessôres; concessão de tempo integral de serviço pirs os orofessores; reconhecimento das Faculdades; contratacă de funcionários, etc. E' surpreendente ou näo? A que ponto estamos chegaflido nesta terra em que há cada vez mais: uma propositada inversão de valores com intençöes incon:Pessáveis!

s. E' absolutamente necessário que as autoridades apurem a razso de origem desta greve. Näo se pode admitir quio continue a marcha de encaminhamento do ensino universitário oficial do Interior para um perigoso abismo. 0 movimento paredista - queira Deus estejamos errado - Paz pensar que as atividades educacionais deste setor sä apenâs motivo para agitação subversiva que agora já se sente nãó apenas como manifestaçäo da própria classe estudantil Tärece que os professôres, colocados em posiçäo sụpe. rior e com possibilidades de extensán de favores numa

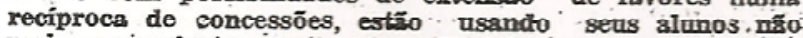
mais comio instrumentos de aplicacia pedagógica, $\mathrm{E}$; cúmulo! Os mestres deveriam é ter evitado a greve a todc custo se tivessem plenta consciêncis da sua nobre missão de educadores. Mesmo que os alunos prefendiessem colocar as reinvidicações de ambas as classes num só movi. mento, deveriam repudiar a iniciativa, desde que justificativa moral alguma pode existir para isso. O exercicio da cátedra implica na condução e orientaçă亍o dos jovens que devem receber não apenas ensinamentos técnicos. $\mathbf{E}$ aquâ. les que não cumprirem a sua missão dentro dos estritos limites da moral, procurando subverter as coisas em lavor de um fim que não se sabe qual, så̄o indígnos daquele ezercício. Principalmente nas Faculdades do Interior onde nenhum catedrítico detem esţ posiça por mérito do con quista, onde todos sãó favorecidos com um contrato tem. porário que representa, sobretado, confiança dos poderes governamentais, desde que siquer procurou-se, por qualquer lorma, medir as possibilidades dos contratados.

Ficamos na expectativa de ampla explicação $\mathrm{f}^{\text {justifica }}$ çäo daquilo que agora denunciamos com. veemencis: guns dos motivos desta greve nos parecem ardilosos 6 . os seus fomentadores, farsantes. Não resistimos à observaçã de que, novamente, "alguem está pretendendo firar as sardinhas da brasa com a mäo do gato".

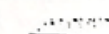

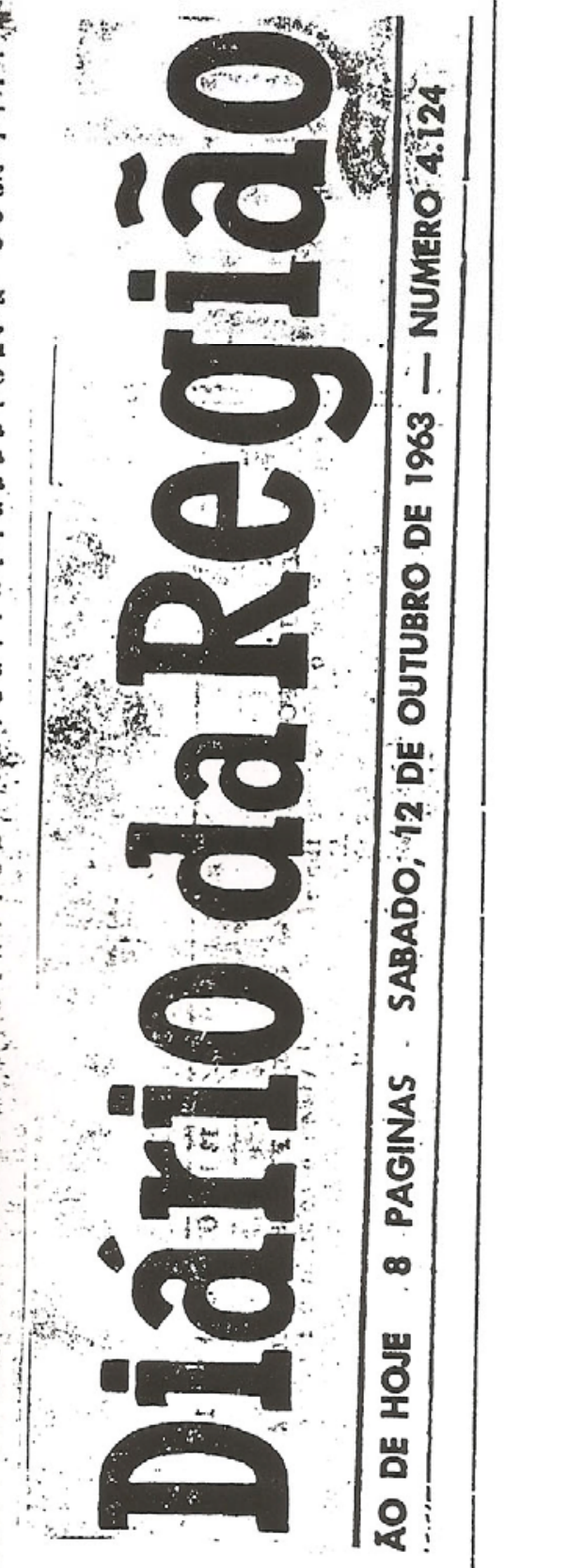




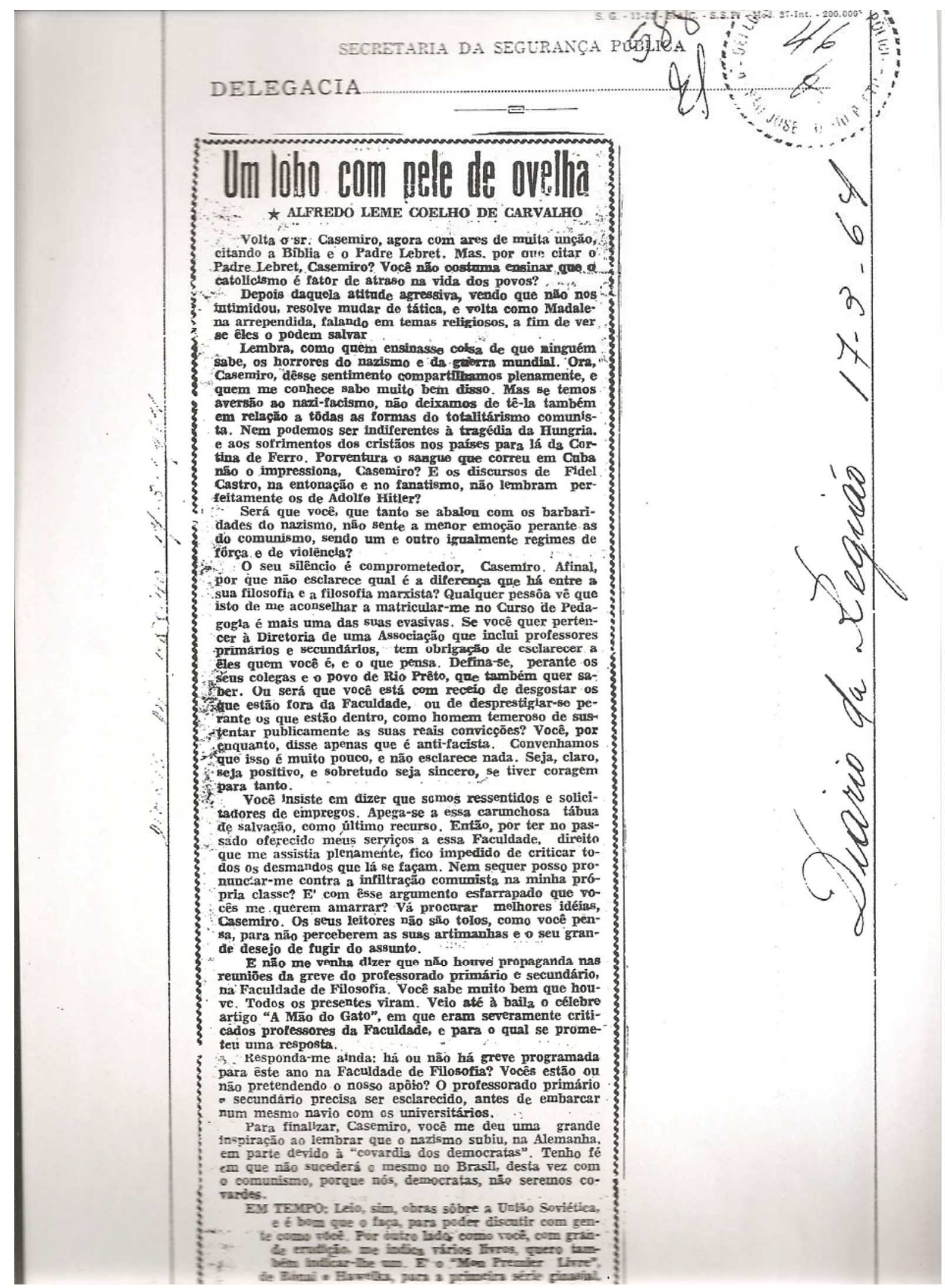




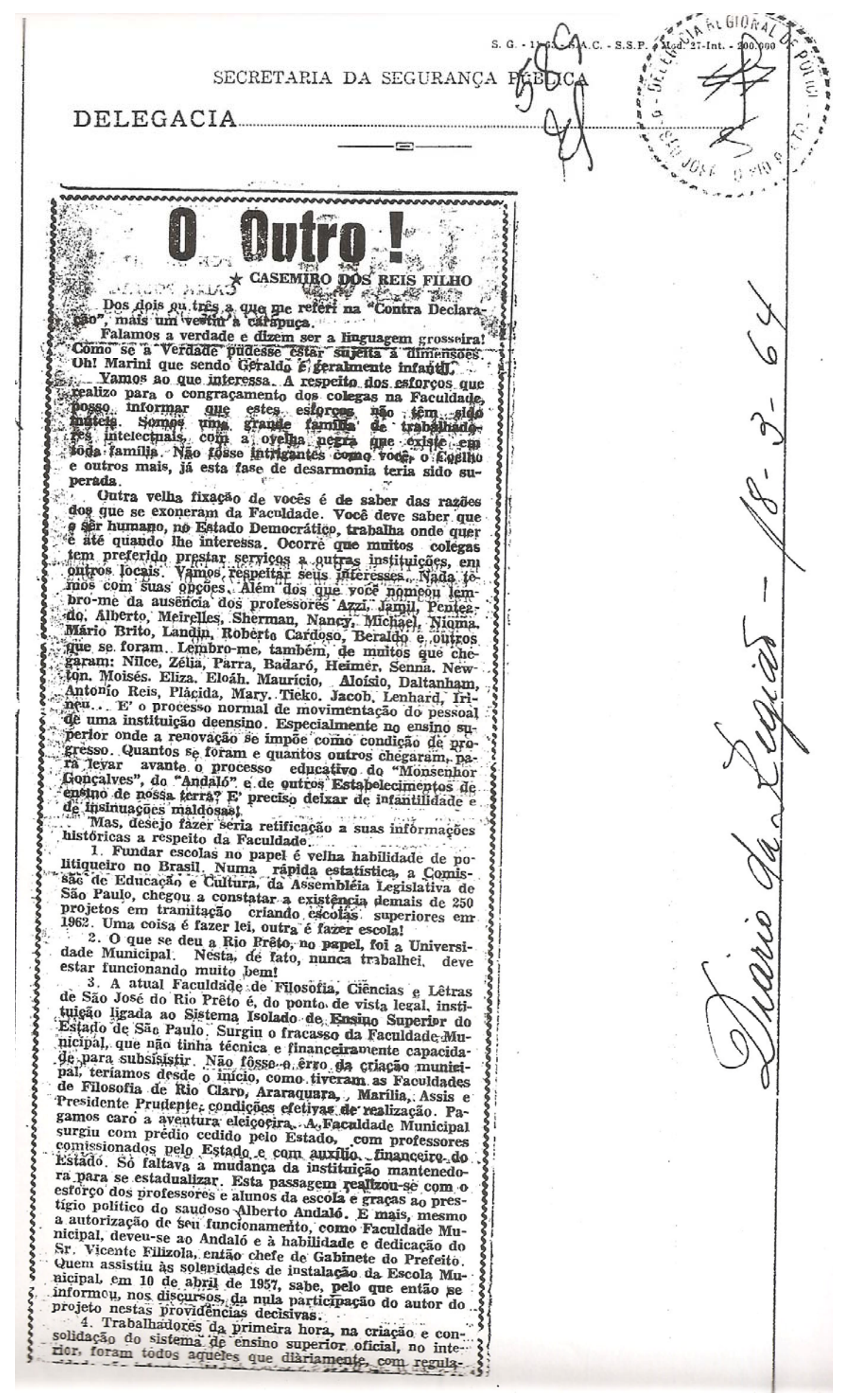




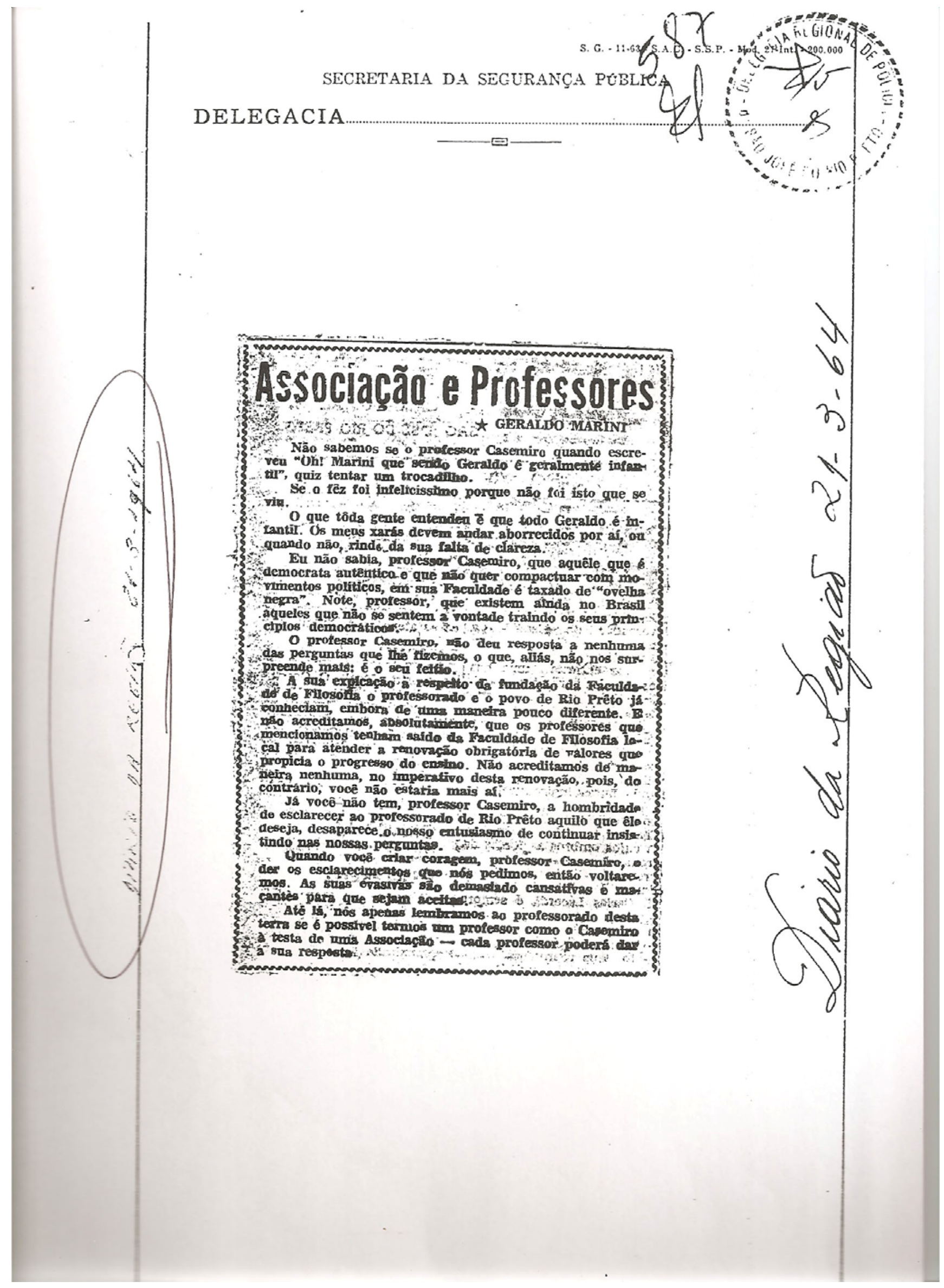


RADIOGRAFIA POUTICA

\section{Provocaram-me; Aqui Esiou}

PROF. DAUD Jorge Simño

Permitam-me adiantar que faz tempo nāo tenho lido
jornais, submetido volumtariamente a um regime do higie : De mental; e porque depois de ter commpletado do higie - calo de existência e de ter servido do 28 alha a muita cas no rosto, mas caes nas atitudes cospirem no prato - degenorados mentalmente, nấ só cospemn tubima bois de tudo isso muitos deles os tirei da miséria: do do - versidade da Vida" Onde nâ hi canalinas camufladoe que para ser livre, livrnho di silva, a melhor fórmula L Fĩá prēso a compromissos do ter de servir a todos. Kense num descanso merecido.
(1a que outros năo dizem

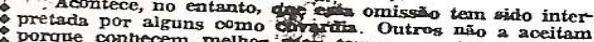
- porque contrecem melhox t. Semperamento. Outros so

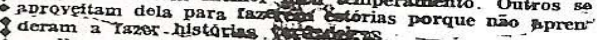

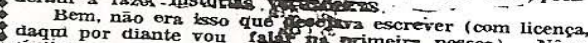
tom; riquemos por ai. O Welto tom depois.

sét uns artigos neste Disro tae helefonaram para que lês.

me tenho andado ataferado com outros problindido. Co da bucolica, mórmente dedicando-me à Cafealtas da aumento ds producino de rei das tontes de divisas do paiss o cấentados e do ainda

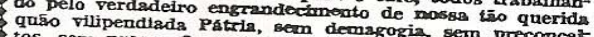
tos, sem presunçôs, todos cooperangogia, sem preconceit pranciplo de uvre adosão, livre contrôle, livedecendo as enfime servindento, sem deturpaçoes, sem mistificasues, nho andado absorvía ó com estes e os proble, repito, to vos dentro de minha área de trabalho nzoblemas educatizer estorias alguem andou rosnando por ai, a pretexto do de Mas logo lerel. O bicho ou os bichos nāo perdem po esperar. rios. o primeiro chero de bom senso, dextos contraditónunciamento do no às liberdades democráticas: é o pro dizendo que nós de Rio Prêto ino dar Mauricio Goular . Fa politica, durante a visita do irovernador Carlos cultuas. E o disse bem. Temos tradicizo politic Carlos Lacer sas dissençōes. Mas quando se trata de ouvir memos nos

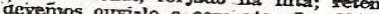
falí. E' um homem com atenção. Não é qualquer um que ; Vamros ourvir Juscelino. Ademar. Arrais gue fala.

Ouvindo, renletindo, analisando, chegamos a uma conmental, rrelexivo, e depois de chegarmos a e elaboraça.

Porisso, Mauricio, receba matous aplausos nor intemoverá. no momento, o pensamento de quase todos in os ripretar, ses cultos politicamente, e que amam res os ripretenpreocupare que naso bão aventureiros parz sugŕla semte o segundo texto, infeliz, insulta tem fora daqui.
pitzlidade. Näo tem assion brios de hostarios" estana origem bem conrecida. Diz que cunsab recisamos identificá-los. Uñ versitós de Rio Prêto? Qupis se forem da Faculdado de Ciências Econômica prêto só gominaram de Faculdade Formados (menoos ea) jü contrados (a deles, não a que eu fundel, seu....). Claro que tarios fithos de familias que ajuoses e muitas. Universicidade, duvido que o fagam; Universitäios ontros estar que, nas condiç̄es dos últimos, estudam fora, também duviqueça de tal forma que venham a vilipendiar suz própria Mas que universitírios? Os que ntho toleram que ou-
tros ralem? s instituicotros verdadeiros são aqueles que-defendem mitern o diślogo, o livro de palavra. Os que não perPrentemente preparando a grilhotina para o ree de Jnscelino de Carrathorsitarios" a presença de Lacenda Arrass, como candidatos a preside, ou de Adernar, ou de pelo a certeza de reajrzasáa de cleiçöes livres prosididas umblicalmente ligada, República a quem a UNE está Ora, se toublicas.
S

podem e devem falar, nasis perante a lei, claro que todos deias dos "Lniversitários". Pois que comungam com as tarem o "enterro" diretio de soltarem boletiom? Do do efeCremos que os saça? (Embora de mau gôsto) cossa forma, mas defendemn o regime, unersitários não agem

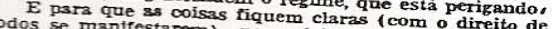
mais universithriog sam o boletim. Não estamos mais se apoiam on nepromcobrem por tras da cortina, ou desmascaramos os que seremos tragados pela
hércia de nossos atos cortina Todos precisam de

etci; e defininseerda, on Juscelimo, on Adermandia. Näo e drvide (ry otīo conosco utrallade (Rui Barbo6sa) onde hi comeles. Não ha Eur convido a tamilia riopretense a dir o exerpio guo - macissa, compacts na grande, memorável, contunder A minhas parte tarei, mesmo com sacrificio.

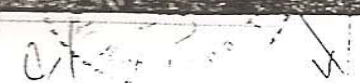

41<smiles>[CH]1[CH]CC1</smiles><smiles>C1CN2CC12</smiles>

$L$<smiles>C1C2C[Si]12</smiles>

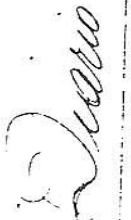




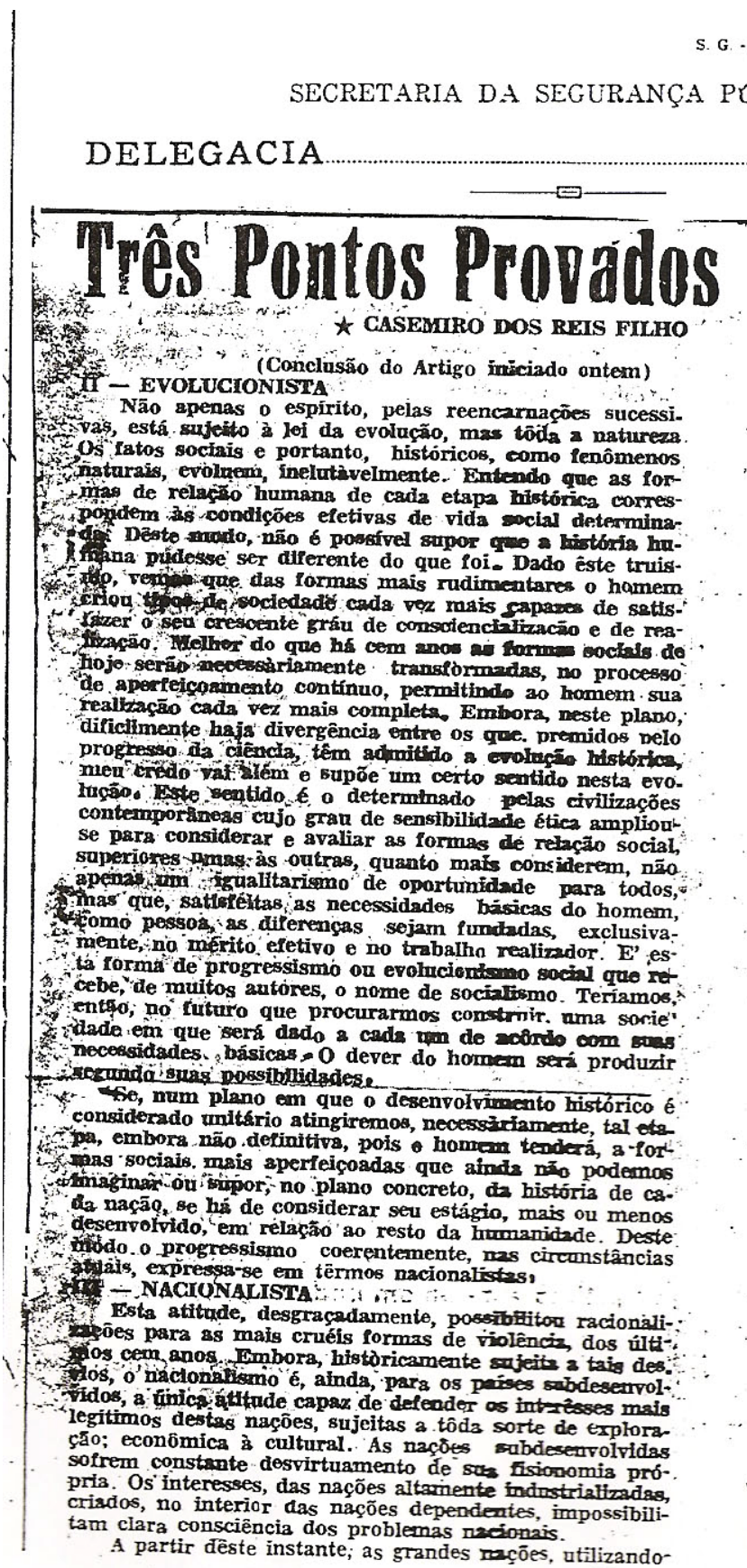




\begin{abstract}
ANEXO 4
A seguir estão as capas da sindicância, do processo crime e do processo militar e o relatório de indiciamento e a denuncia do promotor público militar.
\end{abstract}




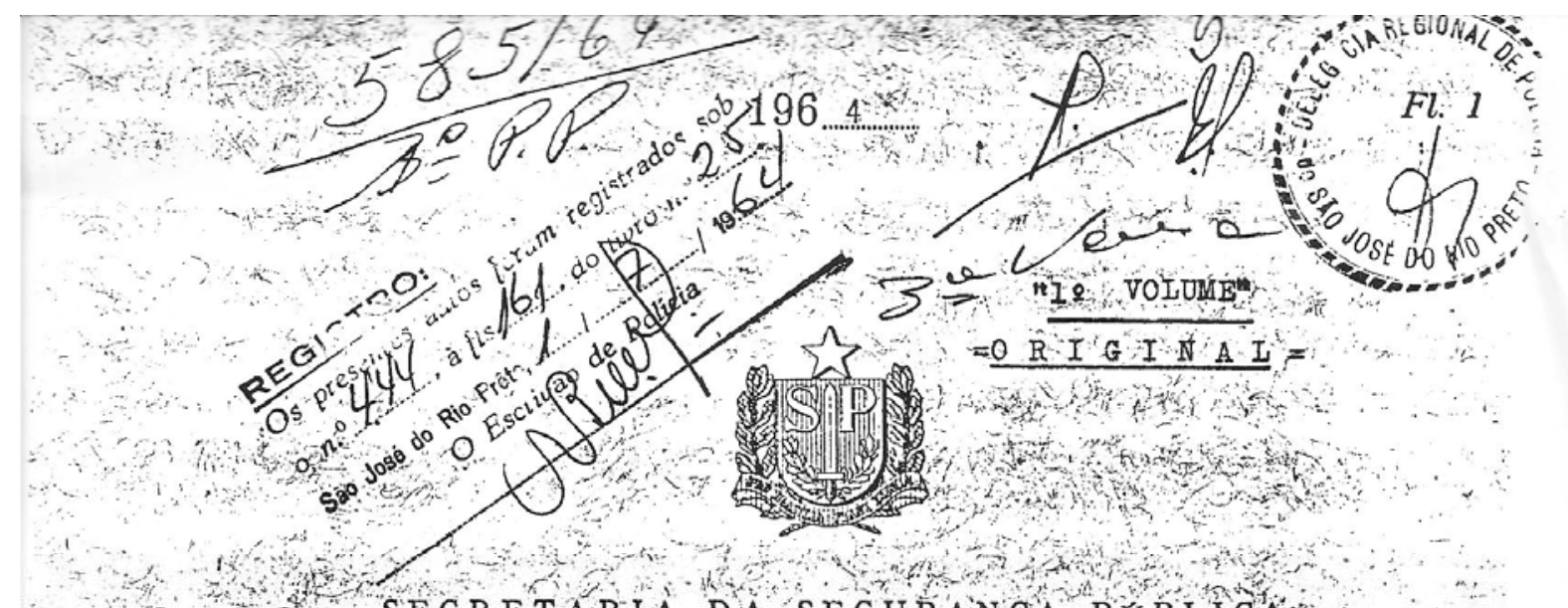
SECRETARIA DA SEGURANGA PUBLICA

\section{DELEGIGIA REGIOTAL DE POLTCIA DE STO JOSE DO RIO PRETO.}

\section{O. ESCr ivão}

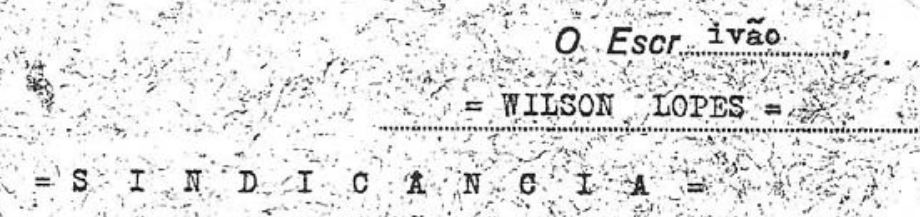

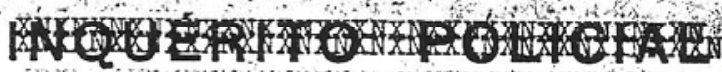

IEI DE SEGURANGA NACIONAL (1.802, de , de joherro de 1953)

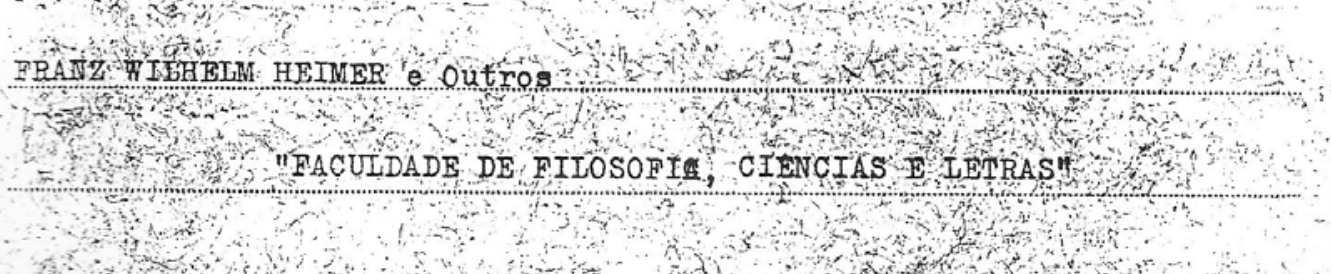

\section{AUTUACAO}

\section{Aos - -primeiro - dias do mês de -abrils}

do and de mil novecentos e sessenta e quatro - n nesta cidade de

- São josédo Rio prêto, na Delegacia de Policia, em meu

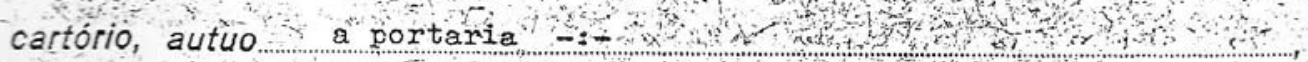

que adiante se segue do que para constar, lavro êste têrmo.

Eu, .

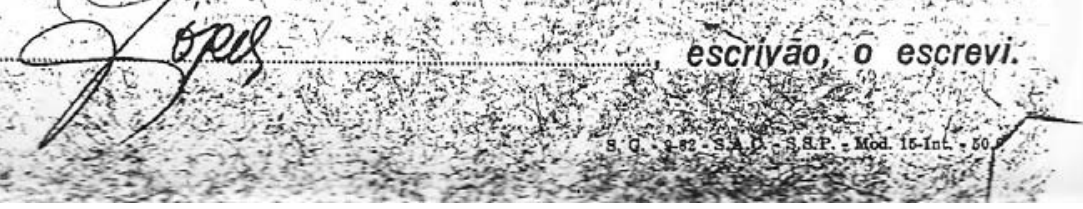




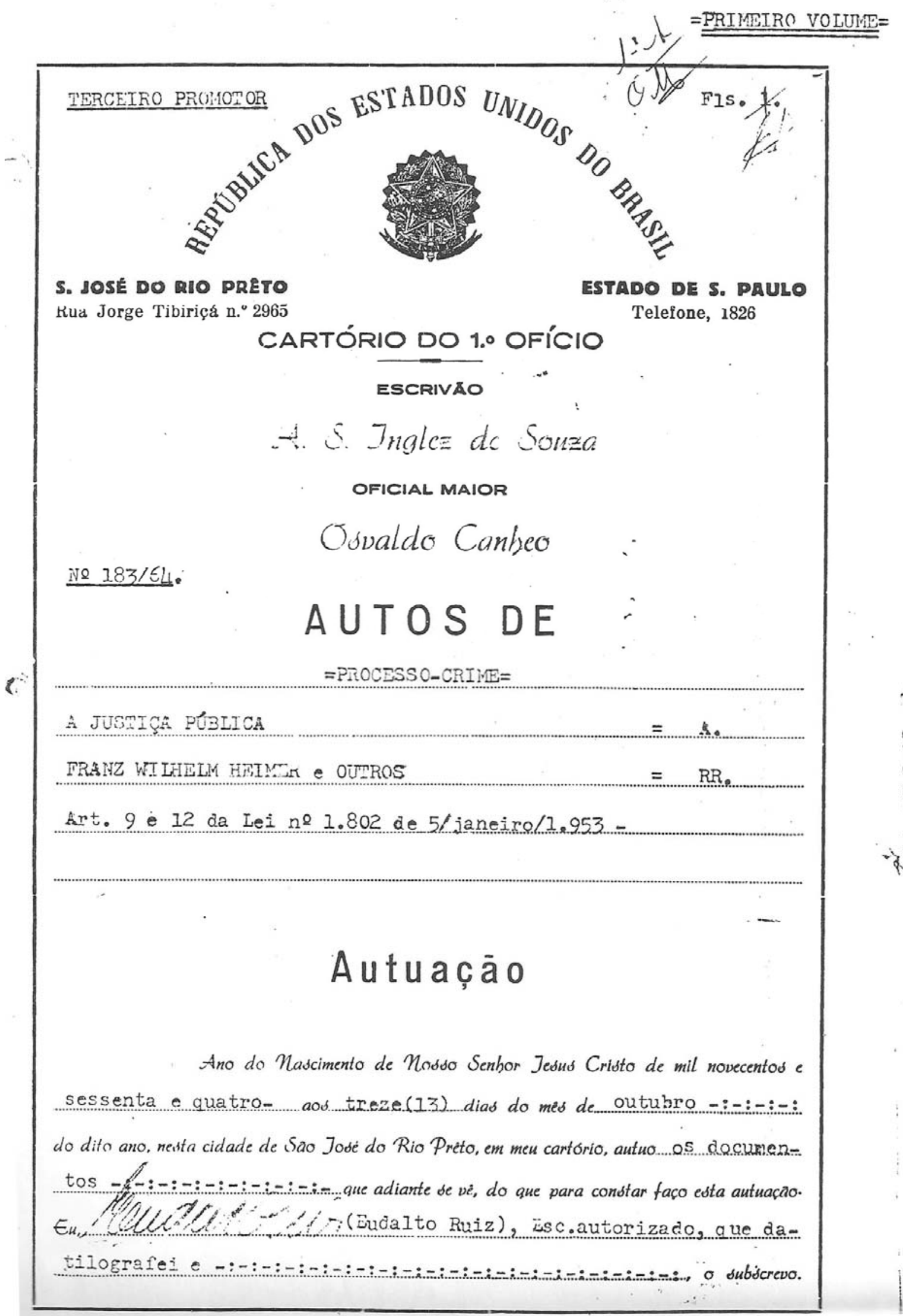




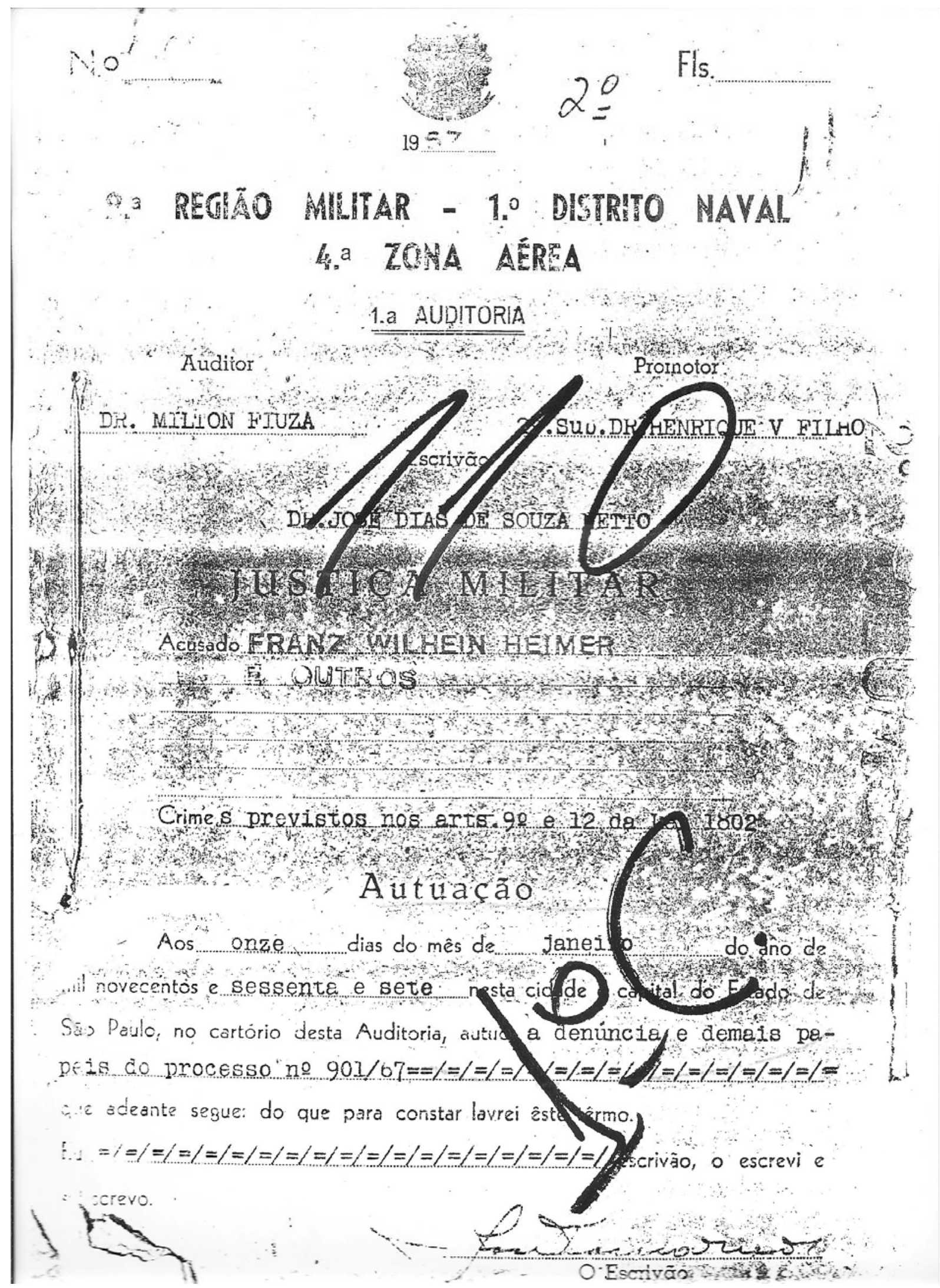


SECRETARIA DA SEGURANÇA PÚBLICA

DELEGACIA REIONA- DOLICIL STC JOSE DO JIC YIRE

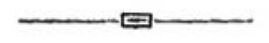

PII $\quad$ I T $\quad 0 \quad R \quad I \quad 0$

\section{IRDICIADOS:}

IHARIA DE LOURDES HEINER, branca, brasileira, casada, com 35 anos de idade, nascida aos 20 aje julho de 1.928, natural de Salvador, Baia, filha de Taldomiro Santos e Balbina Santos, residente nesta cidade, à rua Raul Silva, 160, advogada.

IEDERCY GIGANTE, brance, brasi leira, solteira, universitária, com 20 anos de idade, nascida aos 23 de maio de 1.944, natural de lifirassol, aêste Istad̉o, filha de Hartins Gigante e de Amélia Pizardi, residente nesta cidade, ̀̀ rua Coronel szinola, 3.962 .

FLAVIO VESPASIANO DI GIORGI, branco, brasileiro, casado, natural de Sorocaba, dêste Estado com 31 anos de $i$ dade, nascido aos 17 de abril de 1.933, filho de Antonio Di. Giorgi e de Rosa Pontromolesi, professôr univer sitário, residente nesta cidade, à Avenida de Saudade, 3.476.

DARIA EDITE DO AIIARAI YAZBOGGI

NE, branca, brasileira, casada, professôra, natural ủe Piraci caba, dêste Estado, cor 34 anos de idade, nascida aos 13 de fevereiro de 1.930, filha de José Colombo Gabogrine e de Eaith Bastos do Amaral Garbog̃zine, residente nesta ciàde, ఏ̀ Ave nida da Saudade, 3.476 .

ORTSTTS NIGRO, branco, brasilez ro, casado, professôr, natural de Itapolis, dêste Estado, com 33 anos de idade, nascido aos 31 de julho de.1.932, filho de Vicente $\mathrm{Nigro}$ e de Irabel Sene $\mathrm{Nizro}$, residente nesta cidade, è rua Rubião Jurior, 3.158 .

HEIIO IETTE DE RARROS, branco, brasileiro, casaão, professôr universitário, natural de são Faulc- Capital-, cor. 34 anos de idade, nascido aos 7 de ajôst de 1.929, filho de João ieite de Barros e Vanaa de Oliveira Berros, residente nesta cidade, ̀̀ rua Lafayette Spinola Cas 


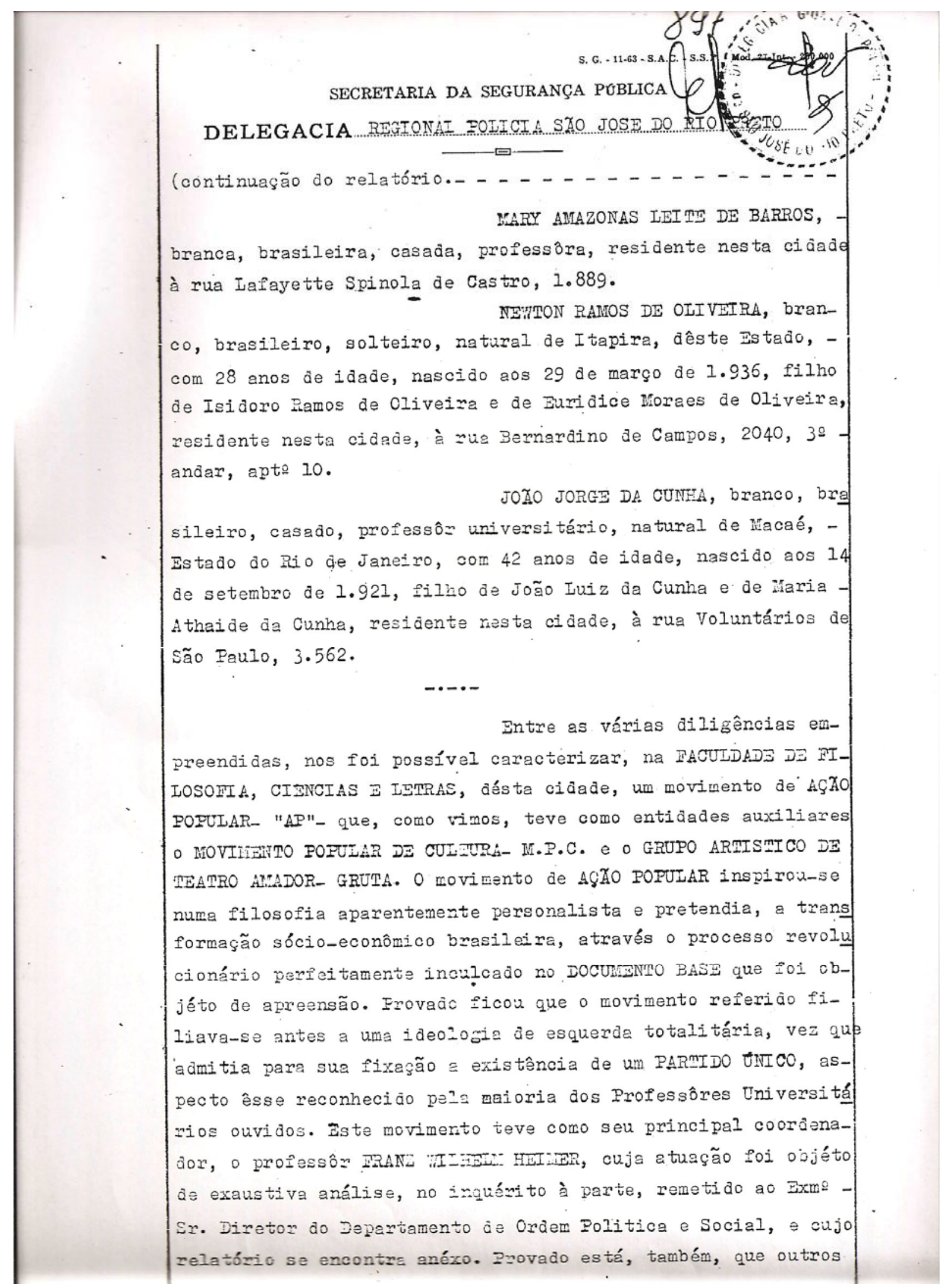


SECRETARIA DA SEGURANÇA PÚBLICA

DELEGACIA

REGIONAI POIICIA SIO JOSE DO RIQ PRITO 므.

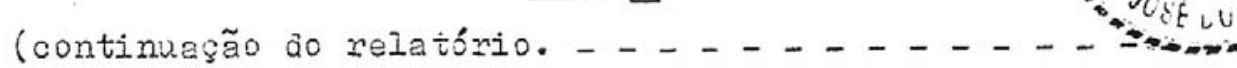

que outros professôres se interessaram pelo referido movimento, entre êles: FIAVIO VESEASIANO DI GIORGI, NEITON RAROS DIT OLIVEIRA, ORTSTES IIGRO, VLRTL EDITH DO ATARAI GARBOGGINE, IHA- . RIL DE IOURDES HEITHP, HALIO IZITE DE BARROS, MARY APAZONAS IAIMY IE ZARROS e a 2luna IZDZRCY GIGANTE.

O professôr FIAVIO VESPASIANO DI GIORGI embora procurasse e= suas declarações, eximí-lo de qual quer tendência esquerdiste, no aspecto filosófico, reconheceuThe, entretanto, pela lingusem obscura utilizada pelo DoctizN TO BASE, consequências nezstivas a perigosas para a estabilidade da estrutura democréúce brasileira. O seu interêsse pelo movimento parece-nos, D̂erfeitamente provado, não apenas por ha ver participado das neuniões na casa do professôr Find TETIER em que foram aiscutidos ne oporturidade as bases daquele movimento, como aināa, pelas suas onóprias esteriorizações no Sindicato da Construção Givil a Imobilíámio desta cidade, e literatura apreendida em seu pođêr.

Wuanto a atuaç̃o do professôr NE: TOI RAMOS DZ OLIVEIR:, pare o movimento em aprêço, bastaria lembrar a sua perticipação nos trabalhos de alfabetização de adultos e constantes dos presentes autos.

Quanto a senhor IFARIA DE IOURDES

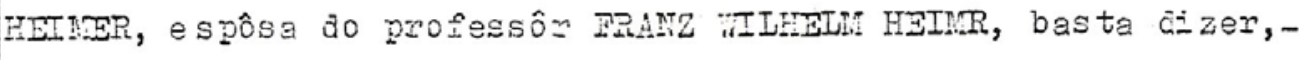

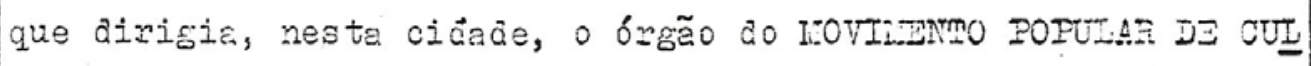

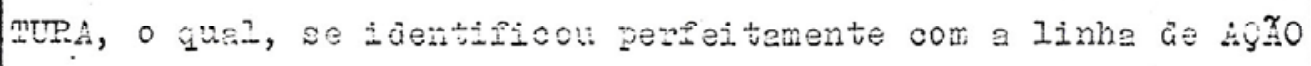
POEULAR.

O profesisôr ORZimes NIGRO éra o responsável pelo GRTM:- GATEO ARTISTCO DE MEAThO AMDOR, órgã vinculado a PRTDLE e que desenvolvie trabelinos de conciencializaş̃o no campo artístico a nas bases pretendidas pelo movimento de As.

wie, relativamemte a profesiors -

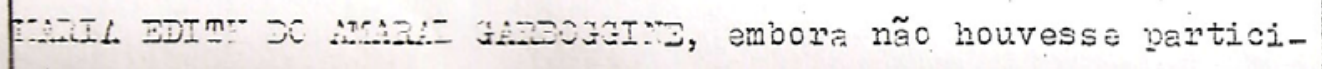
Fado jos motimentos conhecijos pelas sizles M.P.C. e GRUML, prof 


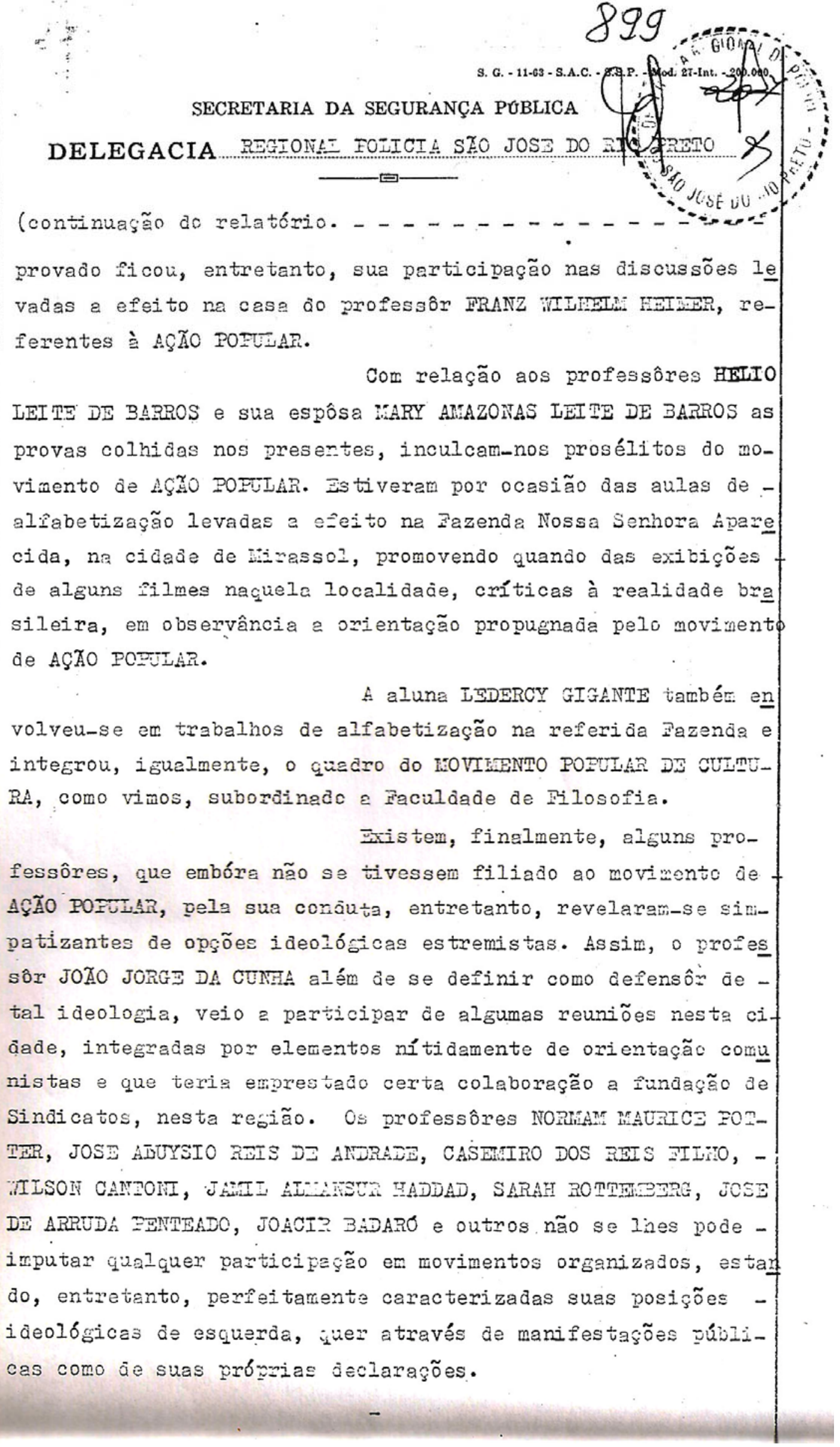


SECRETARIA DA SEGURANÇA PÚBLICA

DELEGACIA RSGIONAI POIICIF STO JOST DO

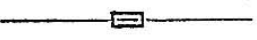

(continuag̃ão do relatório.

\# relatório.

São José do Rio Ereto, 30 de junho de 1.964

OS DELEGADOS DE POIICIA,
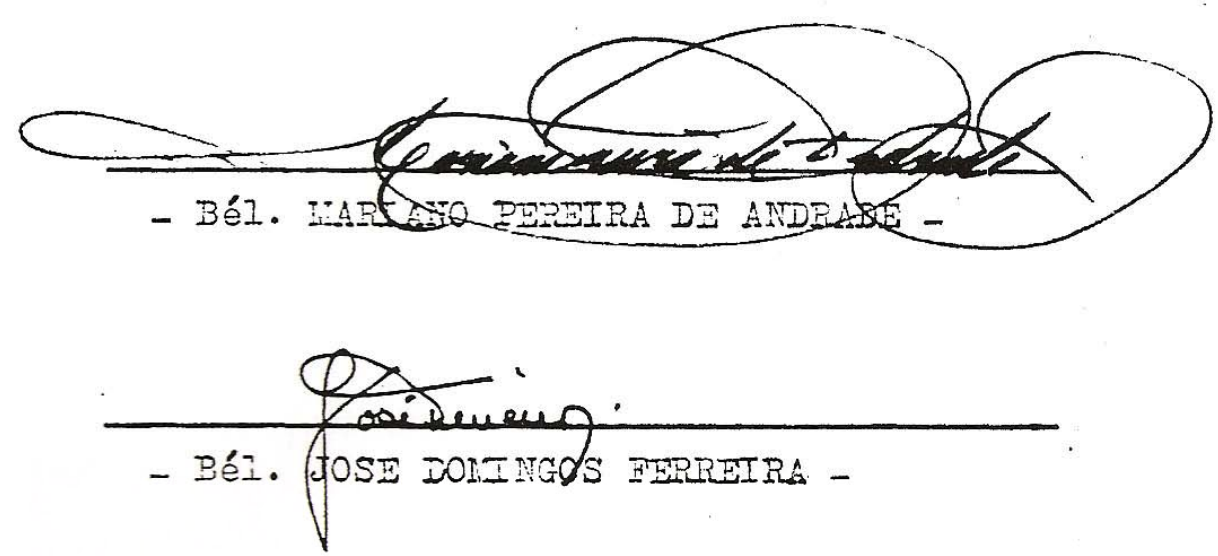

DE ACORDO:

S.J.Rio Zneto, 30 de junho de 1964

O DELEGPDO REGIONAI DE POIICIA,

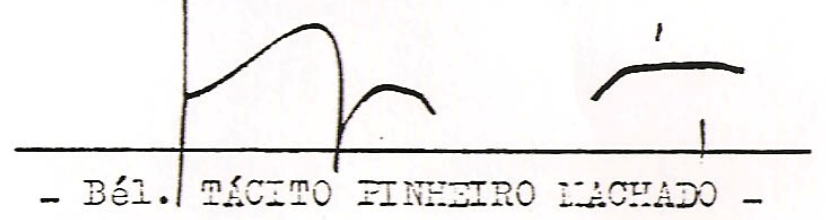




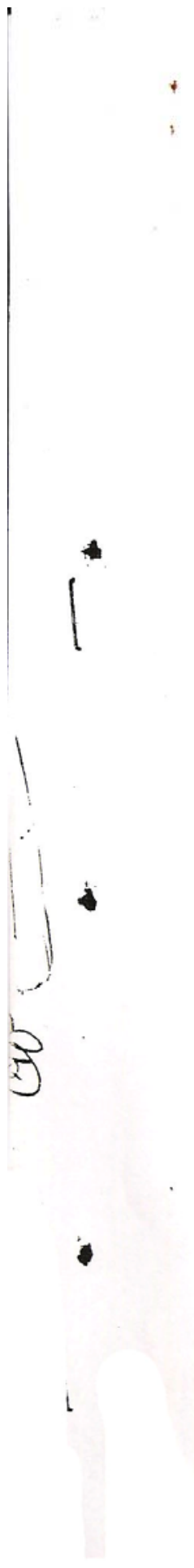

txmo. or is. Juiz Auditor da rrimeire fuditoria da Secunda Reia a lilitar.

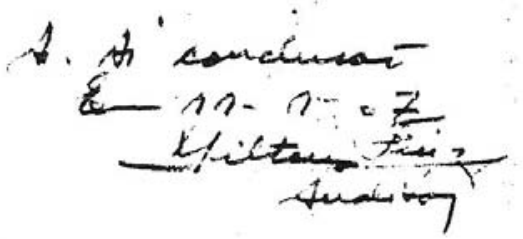

0 Tepresentente to Ministério Mblico "ilitsr que este subscreve, no exercícic de suas atribuiçoce legais, vem denuncicr FRANZ ":IIUEII: HIMTR, qualjficado a fls. 6'/4, WLRA DE LUUDDES HENER, qualiricade a fls. $6 \%$ .IEDERCI GIGANM, qualificada a fls. 6.15, - FLAVIU IESPASIANO DI CIORGI, qualificado a :7s.6\%, - URESTES NIGRO, cquaificado E fls. $6 \%$, - HLIU LPIN EAROS, qua?isicaco a fle. 66a, NDITUN RA:HOS D OLIVEITA, QUelificado o +7s.665, , $\because I S S O N$ CANTONI, qualificado a fls. 902,

com excliså de Lederci Figante, toños êles professôres da ł'aculdade de Tilosoria de Săo cosé do tio Preto, neste E-tado, pelos f'atos que a seguir passe a cxpor:

Na ciàace acime referida, ?umnto ta eclosâo co movimento revolucionkrio de 1464 e consequente levantamentc das práticas subersivas ocorrentes no pais, no seio da Taculdade de Filosofia, tulcro to teje a vide intelectual mais ojevada ha regiâ, for am constatadas fetos gravíssimos, envo!.vendö nomes de parte cos professôres, al zunc dos quais com impricaço intenç.

Sob as denomineçoes de ćen ro fopular de Cultur: Aça Popular, Grupo Art1stico de meatro Amador (Gruta), resteurava-se e era posto en runcionmento, quer velazamente, querie forme meridiana, o $\mathrm{i} . \mathrm{C}$. , que, espraiando-se para as fazendas, penetrando nos ambientes rurais, levave a palavre de Mosccu, disfarçada em teatro ou alfabetizaçao de adultos.

lianto 6 veriade, que ate mesmo os nomes dos mars connecidce bect:dores comuristes i pare exemplo vofre Curre1a Neto. ora aqu, ore 21x, apereciem para solidificar o plenejemento. Apreentide documentecealepostiles, penfletos; 7olantes, pasquins, litretos, opúsculos, critasl nes sedes des entidades referidas, paterteou-se nao serch elas simp?es velculos de culture popular ou Etiviades extracurriculares da Feculaade de Ti osofia. Causou profunta impressao surgirem figuras de relevo na 1 greje Catolice imiscuidas com a arazores vilgares. Inocentes Uteis, visanco o bcm esten social, a redençấo dis massas obreiras, solidificaço dos liames samiliares, uniran sua attvidade à dos 
enissórios da Interracionel Comunicta, sempre viva, setperceber cue solepava a própria fanllia, a propris Igreja. Verifique-se

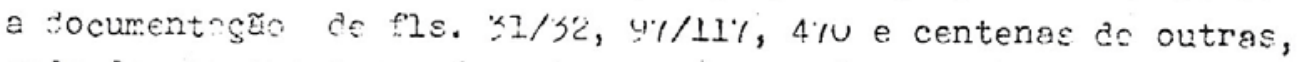
onde de cristianisico so restou o termo e de comunismo a essência. Como jes este Iromotor afirmou, seria extremamente útil que fosse levado acs catolicos mal informacos o persamento dos comuristas a seú respeito: méquina de terreplamagem a abrit as larece estredas des cornentes vemelhas, que, uma vez cumprica a missá, serao eliminadas como escórib prejuicial, ou, no maximo, converticas em sucate social.

Des figures derunciadas, o alemão FRANZ "ILHEIN HEImER, cultíssimo pelo que se depreence dos autos, é uma espécie de seneral. Nao parecs inocente útil, mas hábil em velar as verdadeiras intençбes. Chefia e Áça Tonular, o lovimento Fopular de Culturguvitio a tis. ¿̌u, 11 ná no rega o trabalho que evecuta $e$, tolo seria neEá-1o diente dos docu mentos apreendidos en sua residêncie (fls. 14 e sects.), bem como a aburdantíssima prova testemunhal contre ele existente, una vez ue alvo da acusaçao de quasetudas as testemurhas.

MARLA DE LUUTDE TTUMER, ac conträrio do que se disse de Mary Leite de Larros e warie lite Gartoggine, nac surge como aperies esposa de agitador, passiva, sem maior partıcipaçao. Tla mesma confesse que é secretárie do K.T.u(fls. 291) e êsse movimento está plenamen'e esclarecido nos autos. 'l'ambém é aj.vo za acurango is vorias testemunhas.

I OFEL GIGANTE, de pouce idade, mes taz henre ao rome quanto à habilidade ne pregaçao vermelha. $A$ ? ém das atividades estátıcas, tem una cinámice notável: é a companheira do Frof. Newtor Ramos de Oliveira no"curso de alfabetizaça" que realiza nas fazendas, onde procure jogar o campones contra o fazendetru (doc. de fls. 411,412).

FL"NIO VESPASIAYO DI GIORGI, saIvo outrás provas, é um dos inocentes úteis, Jiltrsimo, Je nome conhecido nás esferes da Linớstica e das tumaniasdes, parece viver for ja realidade social, novimentendo-se mais pelas emoçoes nascidas jas cifrcuns. tâncias do que pelo conhecimento de realidade politica e social. At fiu de?ituosmente quanjo deu seu amparo as entijajes refe icas. Foi além, froserind: paleztras en sedec sirdicais de eltasses inteiramente fors de sue siva se atividades (fIc. 2?'', 261,266,293)

UACOAE Maro é figura de alta projeço. TresiJerte de Aluta, no: se limitou a levar aos palcos a veleze artistica, mas s pregaço vermelha. A fls. 26 I corta como levou a Gruta aos sinizatos. Ora, um rerificesao dos douratnos apreendidosna GNJTA(fls. 653 e sesuintes) mostra quel teatro os operírios tiverem 


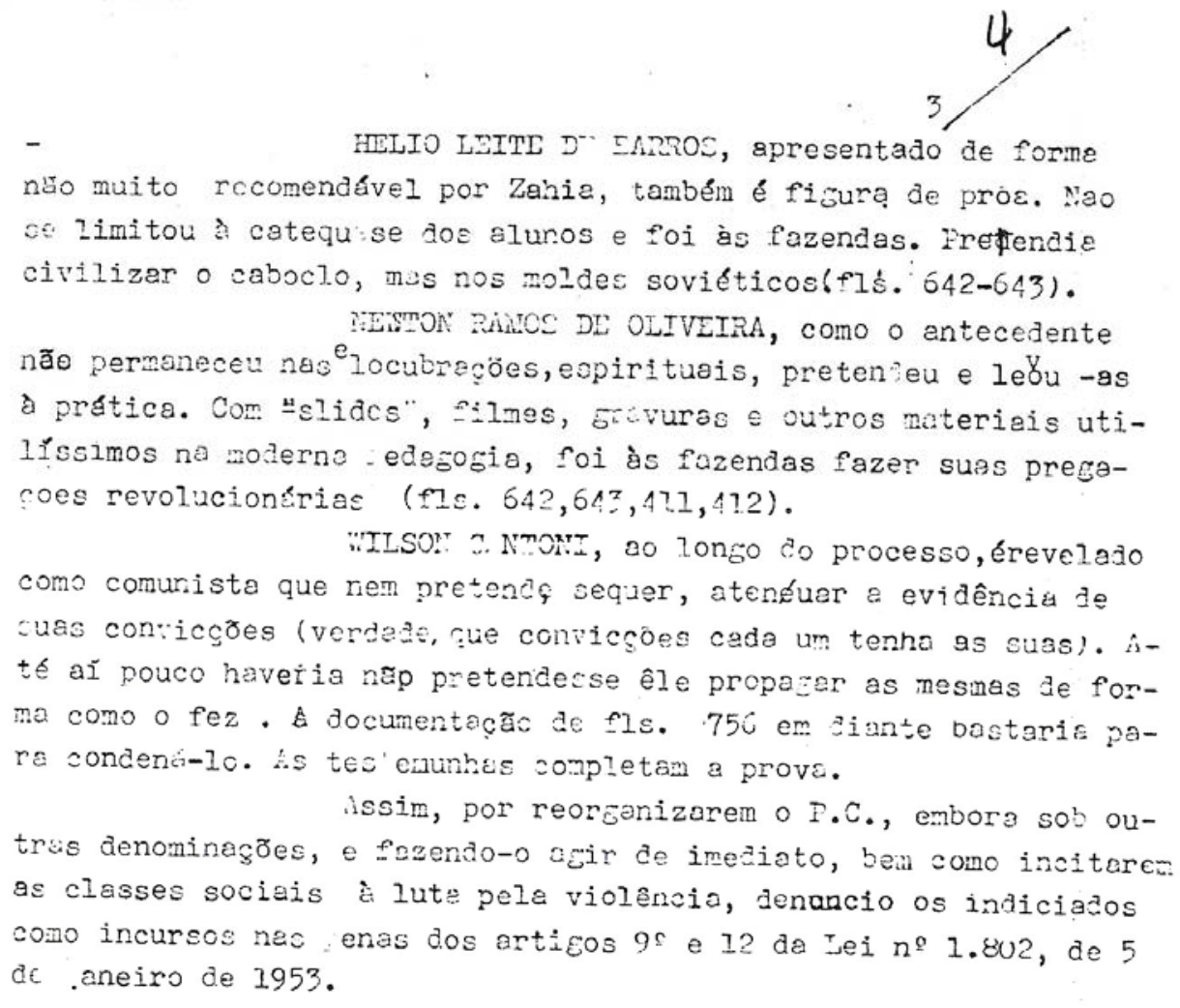

HELIO LEITL D" IRRROS, apresentado de forme năo muito rocomendável por Zahia, também é fizurą de proc. Nao oe limitou à catequ se dos alunos e foi às fazendas. Frefendie civilizar o caboclo, mes nos moldes soviéticos(flś. 642-643). VESTON RAILCS DE OLIVEIRA, como o antecedente nãe permaneceu nas locubreçöes, espirituais, preten eu e leరu -as à pratica. Com "slides", filmes, frevuros e outros materiais utilíssimos na moderno edecogia, foi às fazendas fazer suas pregacoes revolucionśrias ( $f 12.642,647,4 ! 1,412$ ).

"ILSO!: C. NONT, do lonso do processo, érevelado como comurista que rem pretendg sequer, atenduar a evidência de cuas con:icçes (verdede, cue convicsoes cada um tenha as suas). htê aí pouco haveria nap pretendecse êle propazer as mesinas de forma como o fez. A documentaça de fls. $756 \mathrm{em}$ ziante bastaris para condenci-lo. hs tes' eaunhes completam a prova. issim, por reorenizarem o P.C., embora sob outras denominazgos, e fazendo-o a cir de imediato, bea como incitare as classes sociais à lute pele violennia, denancio os indiciajos como incursos neo enas dos artícos 95 e 12 da tei no 1.802 , de 5 de .aneiro de 1953.

Fiequeiro sujam ouvides as testemunhas abaixo.

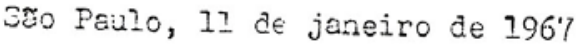

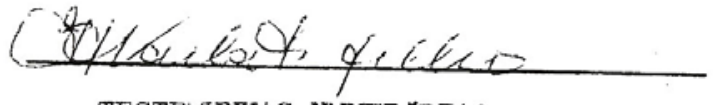

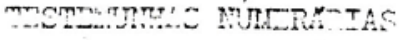

2) Caud Jorge sima- $92.25 \% \mathrm{kt}$

2) vvone de Noura Gampos $A$ A Almeida-fls. 366 e

z) Euclides Pelacani. Ms.4II L

4) Sebastiao tese de Kocha $412 . \nu$ r

5) sdelino Delamoura elc. $413 \mathrm{l}^{\prime} t$

c) La'rcio Falacani- 11 s. $414 . V *$

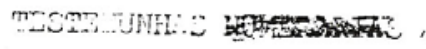

-?) Ithevaldo de Nelo Siqueire flo. $228 \mathrm{r}$ :

2) Edoardo cuerin-fls. 288. It

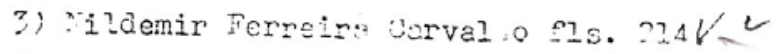

4) Yauro 0aevil . Via -fls. $226=$ ?

5) Crigor vertanian- flle 3ơ $7 \mathrm{~V}$

¿) Cosemiro dos Fieis Fitho Ns. 4 ue? 